Інститут вищої освіти НАПН України

Відділ інтеграції вищої освіти і науки

Теоретичні основи розвитку науково-педагогічного потенціалу університетів України у контексті розширення інституційної автономії препринт (аналітичні матеріали)

Київ - 2020 
Теоретичні основи розвитку науково-педагогічного потенціалу університетів України у контексті розширення інституційної автономії : препринт (аналітичні матеріали) (І частина) / авт. кол.: О. Жабенко, В. Муромець, І. Регейло, Ю. Скиба, Г. Чорнойван, О. Ярошенко ; за ред. Ю. Скиби. Київ : ІВО НАПН України, 2020. -113 c.

Рекомендовано до друку рішенням Вченої ради Інституту вищої освіти НАПН України (протокол № 7/4, від 23 листопада 2020 р.)

Аналітичні матеріали (препринт) присвячено проблемі розвитку науково-педагогічного потенціалу університетів України в контексті розширення інституційної автономії. Авторами на основі аналізу вітчизняних і зарубіжних наукових праць визначено й обгрунтовано теоретичні основи (гіпотези, закономірності, тенденцій, принцип) розвитку науково-педагогічного потенціалу університетів України. Запропоновано розвиток науково-педагогічного потенціалу здійснювати за рівнями (інституційний, особистісний) та компонентами (інтелектуальний, емоційний, духовний). Обґрунтовано інноваційні педагогічні технології (супервізія, теленаставництво, ситуативне навчання та ін.) розвитку науковопедагогічних працівників. Уточнено підходи до оцінювання наукової активності науково-педагогічних працівників відповідно до концепції бібліометрики та концепції досконалості у вищій освіті та дослідженнях.

Упровадження аналітичних матеріалів (препринту) сприятиме залученню розробників освітньої політики, керівників закладів вищої освіти, науковців, науково-педагогічних працівників і здобувачів вищої освіти до теоретичних основ розвитку науково-педагогічного потенціалу університетів України з метою розроблення стратегій розвитку університетів, підвищення їх рейтингу та конкурентоспроможності в Європейському просторі вищої освіти.

Для розробників освітньої політики, науковців, керівників закладів вищої освіти, науково-педагогічних працівників і здобувачів вищої освіти.

(C) Інститут вищої освіти НАПН України, 2020

(C) Колектив авторів, 2020 


\section{Зміст}

Передмова

. .4

\section{Юрій Скиба}

Теоретичні основи розвитку потенціалу викладачів університетів України

у контексті розширення інституційної автономії.

Ганна Чорнойван

Розвиток дослідників (наукових працівників) в університетах України

в умовах євроінтеграції: теоретичні основи

Олександр Жабенко

Розвиток управлінського персоналу університетів України у контексті розширення

інституційної автономії: теоретичні основи

Ольга Ярошенко

Теоретичні основи рейтингування як інструменту оцінювання діяльності

науково-педагогічних працівників університетів України

Ірина Регейло

Теоретичні основи оцінювання та розвитку науково-педагогічних працівників університетів у контексті реалізації наукової діяльності

Вікторія Муромець

Теоретичні основи використання інноваційних технології розвитку науково-педагогічних працівників закладів вищої освіти: психологічний і колегіальний підходи 


\section{Передмова}

Прагнення університетів України долучитися до Європейського простору вищої освіти й повноцінної співпраці із закладами вищої освіти у його межах передбачає виконання певних умов / зобов'язань, які знайшли відображення у чинному законодавстві України. Серед шляхів реалізації державної політики у сфері вищої освіти визначено необхідність розвитку автономії закладів вищої освіти, що передбачає збільшення самостійності, незалежності й відповідальності університетів у прийнятті рішень щодо розвитку академічних свобод, організації освітнього процесу, наукових досліджень, внутрішнього управління, добору і розстановки кадрів, економічної та інших видів діяльності.

Приєднання університетів України до Європейського простору вищої освіти є свідченням їх конкурентоспроможності на європейському ринку освітніх послуг. Визначальну роль у конкурентоспроможності університету відіграє високий рівень його науково-педагогічного персоналу. Тому в умовах розширення інституційної автономії вітчизняним університетам необхідно сконцентрувати увагу на розвиток власного науково-педагогічного потенціалу.

На розроблення науково-обґрунтованих підходів і механізмів щодо розвитку науково-педагогічного потенціалу спрямована тема фундаментального наукового дослідження відділу інтеграції вищої освіти і науки: «Теоретичні основи і механізми розвитку науково-педагогічного потенціалу університетів України у контексті розширення інституційної автономії».

На першому етапі наукового дослідження «Обгрунтування теоретичних основ розвитку науковопедагогічного потенціалу університетів України у контексті розширення інституційної автономії» співробітники відділу інтеграції вищої освіти і науки зосередили увагу на визначенні теоретичних основ (гіпотези, закономірностей, тенденцій, принципів) розвитку потенціалу викладачів, дослідників та управлінців університетів України у контексті розширення інституційної автономії та євроінтеграції. Здійснено аналіз інструментів оцінювання викладацької та наукової діяльності науково-педагогічних працівників університетів України. Обгрунтовано психологічний і колегіальний підходи щодо використання інноваційних педагогічних технологій розвитку науково-педагогічних працівників закладів вищої освіти.

Наукові результати отримані на першому етапі дослідження $є$ основою для виконання завдання другого етапу наукового дослідження, що полягає в аналізі провідного вітчизняного та зарубіжного досвіду з розвитку науково-педагогічного потенціалу університетів. 


\title{
Теоретичні основи розвитку потенціалу викладачів університетів України у контексті розширення інституційної автономії
}

\author{
Юрій Скиба, \\ доктор педагогічних наук, дочент, \\ завідувач відділу, \\ Відділ інтеграції вищої освіти і науки, \\ Інститут вищої освіти НАПН України, \\ https://orcid.org/0000-0003-2238-8272
}

Анотація. У розділі виявлено сутність та подано визначення понять «викладач», «викладацька діяльність», «розвиток потенціалу викладачів університетів». Вставнолено закономірність і тенденції розвитку потенціалу викладачів університетів. Визначено принципи розвитку потенціалу викладачів університетів. Обгрунтовано сутність та структуру викладацької метакомпетентності. Виявлено професійні ролі викладачів університету та їх відповідність видам викладацької діяльності. Визначено рівні (особистісний, інституційний) і компоненти (інтелектуальний, емоційний і духовний) розвитку потенціалу викладачів університетів.

Ключові слова: викладач, викладацька компетентність, інтелектуальний компонент, емоційний компонент, духовний компонент, потенціал, розвиток потенціалу, професійні ролі викладача, університет. 


\section{Актуальність проблеми розвитку потенціалу викладачів університетів}

В останні роки в стратегічних документах світового та європейського рівнів (Supporting growth and jobs - an agenda for the modernization of Europe's higher education systems. Communication from the European Commission to the European Parliament, the Council, the European Economic and Social Committee and the Committee of the Regions ${ }^{1}$, Bucharest Communique "Making the Most of Our Potential: Consolidating the European Higher Education Area» ${ }^{2}$, Yerevan Communiqué: EHEA Ministerial Conference ${ }^{3}$ ) на нормативних національних документах (Законах України «Про вищу освіту» ${ }^{4}$, «Про наукову $i$ науково-технічну діяльність» ${ }^{5}$, «Про освіту» $\left.{ }^{6}\right)$, а також у наукових джерелах наголошується, що розвиток потенціалу викладачів університетів у контексті викладання і навчання має служити цілям підвищення якості освіти і посилення соціальної функції університетів.

У статті 431 Угоди про асоціацію між Україною та Європейським Союзом ${ }^{7}$ передбачено активізацію співробітництва в галузі вищої освіти з метою підвищення якості та важливості вищої освіти. Одним із аспектів підвищення якості є розвиток потенціалу викладачів університетів.

Про актуальність дослідження свідчить і Паризьке комюніке 8 у якому наголошується, що основною метою структурних реформ є забезпечення та підвищенні якості й актуальності навчання і викладання. Тому в рамках реалізації передбачених заходів, особлива увага приділятиметься розробленню нових підходів до безперервного вдосконалення навчання і викладання в рамках Європейського простору вищої освіти.

Актуальність дослідження підтверджується і проектом «Стратегії розвитку вищої освіти в Україні на 2021-2031 роки» ${ }^{9}$ де вказано, що «низька затребуваність державою педагогічної і наукової праці, її низька оплата призвели до падіння престижності цього виду діяльності та скорочення кількості викладачів в університетах. Так, за період із 2010 р. по 2019 р. загальна кількість викладачів університетів, академій та інститутів знизилася на 22,4\% (до 133,5 тис. осіб)» ${ }^{10}$. Це пов'язано із низкою причин, а саме: «...3 недостатньою мотивацією науково-педагогічних працівників забезпечувати і здійснювати освітній процес на високому методичному і науковому рівні; недосконалою тарифною політикою у сфері оплати праці викладачів; падінням престижу викладацької діяльності; великим навчальним навантаження викладачів; відсутністю реальних можливостей для академічної мобільності; проходженням підвищення кваліфікації за власні кошти викладача; застарілістю або відсутністю необхідної і достатньої дослідницької, інформаційної й іншої інфраструктури для самовдосконалення викладачів тощо. У той час, як «місією вищої освіти $\epsilon$ забезпечення сталого інноваційного розвитку України через підготовку висококваліфікованих фахівців, створення та поширення знань, формування інтелектуального, соціального та духовного капіталу суспільства, готового до викликів майбутнього» ${ }^{11}$.

Свідченням актуальності означеної проблеми $є$ результати опитування учасників освітнього процесу університетів, що подані у праці «Результати загальнонаціонального опитування «Перспективи та потреби розвитку університетів України у процесі реформування вищої освіти у контексті європейської

\footnotetext{
${ }^{1}$ Supporting growth and jobs - an agenda for the modernization of Europe's higher education systems. Communication from the European Commission to the European Parliament, the Council, the European Economic and Social Committee and the Committee of the Regions, Brussels, XXX. - COM(2011) 567/2. \{SEC(2011) 1063\}. 16 p.

2 Bucharest Communiqué «Making the Most of Our Potential: Consolidating the European Higher Education Area», Bucharest, on 26 and 27 April 2012. URL : http://www.ehea.info/Uploads/(1)/Bucharest\%20Communique\%202012(1).pdf.

3 Yerevan Communiqué : EHEA Ministerial Conference, 2015. URL : http://www.ehea.info/Uploads/SubmitedFiles/5 2015/112705.pdf.

4 Про вищу освіту : Закон України від 01.07.2014 № 1556-VII. URL : https://zakon.rada.gov.ua/laws/show/1556-18?find.

5 Про наукову і науково-технічну діяльність : Закон України від 26.11.2015 № 848-VIII. URL : https://zakon.rada.gov.ua/laws/show/84819\#Text.

6 Про освіту : Закон України від 05.09.2017 № 2145-VIII. URL : https://zakon.rada.gov.ua/laws/show/2145-19.

7 Угода про асоціацію між Україною, з однієї сторони, та Європейським Союзом, Європейським співтовариством з атомної енергії і їхніми державами-членами, 3 іншої сторони : ратифіковано Законом України від 16.09.2014 № 1678-VII. URL: https://zakon.rada.gov.ua/laws/show/984 011\#Text.

${ }^{8}$ Paris Communiqué. Paris, May 25th 2018. URL: http://www.ehea.info/media.ehea.info/file/BFUG Meeting/48/8/BFUG BG SR 61 4 FinalDraftCommunique 947488.pdf.

${ }_{9}^{9}$ Стратегія розвитку вищої освіти в Україні на 2021-2031 роки. К., 2020. 71 с. URL: https://mon.gov.ua/storage/app/media/rizne/ 2020/09/25/rozvitku-vishchoi-osviti-v-ukraini-02-10-2020.pdf.

${ }^{10}$ Стратегія розвитку вищої освіти в Україні на 2021-2031 роки. К., 2020. 71 с. C. 20-21. URL : https://mon.gov.ua/storage/app/media/ rizne/2020/09/25/rozvitku-vishchoi-osviti-v-ukraini-02-10-2020.pdf.

${ }_{11}$ Стратегія розвитку вищої освіти в Україні на 2021-2031 роки. К., 2020. 71 с. С. 35. URL : https://mon.gov.ua/storage/app/media/rizne/ 2020/09/25/rozvitku-vishchoi-osviti-v-ukraini-02-10-2020.pdf.
} 
інтеграції» ${ }^{12}$. Зокрема, у висновках до розділу «Професійний розвиток науково-педагогічних працівників» зазначено, «...що найбільш поширеною формою розвитку викладацької компетентності залишається досить «традиційна» форма у вигляді методологічних семінарів - їі відзначили 60 \% викладачів / дослідників, другу позицію у категорії викладачі / дослідники посіли «вибіркові тренінги / курси для покращення викладання» (43 \%) і на третьому місці «зворотній зв'язок з боку колег-викладачів» (42%)» ${ }^{13}$.

Водночас у дослідженні зазначено ${ }^{14}$, що «досягнення у викладацькій діяльності» виявилися лише на третьому місці з чотирьох за пріоритетністю у групі «викладачі / дослідники», що засвідчує відсутність пріоритетності у кадровій політиці у вищій освіті (на національному та інституційному рівнях) та відповідно відсутність прагнення на рівні ЗВО до забезпечення «цінності якісного викладання», що є критично важливим для забезпечення високої якості вищої освіти.

Отже, домінуючими в університетах, в умовах сьогодення, є традиційні форми професійного розвитку викладацької компетентності. Поряд із цим, спектр форм професійного розвитку викладацької компетентності в університетах $€$ достатньо широким і наявні всі передумови для впровадження та розвитку інноваційних форм».

Отже, актуальність проблеми розвитку потенціалу викладачів університетів України у контексті розширення інституційної автономії не викликає сумніву.

Мета дослідження: обгрунтувати теоретичні основи розвитку потенціалу викладачів університетів України у контексті розширення інституційної автономії.

Завдання дослідження: здійснити аналіз вітчизняних та зарубіжних наукових праць із проблеми розвитку потенціалу викладачів університетів у контексті розширення інституційної автономії; обґрунтувати поняттєво-термінологічний апарат розвитку потенціалу викладачів університетів; визначити принципи розвитку потенціалу викладачів університетів; виокремити структурні компоненти викладацької компетентності; визначити та охарактеризувати професійні ролі викладача університету.

Meтоди дослідження. Для досягнення мети та вирішення поставлених завдань використано комплекс методів наукового дослідження: порівняльний, контент-аналіз, узагальнення, систематизація - для обгрунтування та визначення стану розроблення досліджуваної проблеми у вітчизняних та зарубіжних наукових працях, політичних та стратегічних документах європейського рівня щодо розвитку вищої освіти, аналітичних матеріалах міжнародних організацій; поняттєво-термінологічний аналіз - для визначення сутності розвитку потенціалу викладачів університетів; структурно-системний аналіз - для визначення структури викладацької компетентності.

\footnotetext{
12 Результати загальнонаціонального опитування «Перспективи та потреби розвитку університетів України у процесі реформування вищої освіти у контексті європейської інтеграції» ; за заг. ред С. Калашнікової. К. : Інститут вищої освіти HAПH України, 2019. 64 с. URL : https://ul-journal.org/index.php/journal/article/view/105/98.

13 Результати загальнонаціонального опитування «Перспективи та потреби розвитку університетів України у процесі реформування вищої освіти у контексті європейської інтеграції» ; за заг. ред С. Калашнікової. К. : Інститут вищої освіти HAПH України, 2019. 64 с. URL : https://ul-journal.org/index.php/journal/article/view/105/98.

${ }_{14}$ Результати загальнонаціонального опитування «Перспективи та потреби розвитку університетів України у процесі реформування вищої освіти у контексті європейської інтеграції» ; за заг. ред С. Калашнікової. К. : Інститут вищої освіти НАПН України, 2019. С. 17. URL : https://ul-journal.org/index.php/journal/article/view/105/98.
} 


\section{Визначення теоретичних основ проблеми розвитку потенціалу викладачів університетів у контексті розширення інституційної автономії}

\section{Концепція дослідження.}

Особливості процесу розвитку потенціалу науково-педагогічних працівників університетів зумовили вироблення концептуальних засад дослідження, які потребують обґрунтування на теоретичному рівні.

Теоретичний концепт визначає систему психолого-педагогічних ідей, підходів, принципів, що виявляють сутність і структуру потенціалу науково-педагогічних працівників університетів і яка грунтується на: положеннях теорії розвитку людського капіталу; положеннях теорії особистості; концепціях досконалості у вищій освіті та наукових дослідженнях тощо.

\section{Гinoтеза:}

Розвиток потенціалу викладачів університетів України у контексті розширення інституційної автономії буде ефективним за умови визначення та обгрунтування теоретичних основ (закономірностей, тенденцій, принципів тощо) на засадах теорії розвитку людського капіталу. Встановлені закономірності, тенденції, принципи, методи розвитку потенціалу викладачів університетів сприятимуть підвищенню ї ефективності та соціальної відповідальності вітчизняних університетів перед суспільством.

\section{Поняттєво-термінологічний апарат проблеми розвитку потенціалу викладачів університетів}

Розуміння сутності поняття «потенціал викладача університету» потребує аналізу його основних складових, а саме: викладач університету, викладацька діяльність, потенціал, науково-педагогічний потенціал університету. Насамперед, проаналізуємо поняття «викладач університету».

Чинними Законами України «Про освіту» ${ }^{15}$ і «Про вищу освіту» ${ }^{16}$ понятяя «викладач» розглядається як посада, проте у Класифікаторі професій ДК 003:2010 ${ }^{17}$ - як професія. Зокрема, у підрозділ 23 «Викладачі», виокремлено такі класи:

231 «Викладачі університетів та вищих навчальних закладів»;

232 «Викладачі середніх навчальних закладів»;

235 «ншші професіонали в галузі навчання».

Необхідно зазначити, що Класифікатор професій дК 003:2010 охоплює поняттям «викладач» доволі широку сферу професійної діяльності ${ }^{18}$.

У нашому дослідженні поняття «викладач університету» тлумачимо в широкому його розумінні це особа, яка здійснює викладацьку діяльність в університеті та зарахована до складу штатних прачівників університету на основі відповідного трудового або иивільно-правового договору. Оформлення на роботу на певну частину ставки згідно з вимогами Кодексу про працю України не $є$ обов'язковою умовою під час здійснення викладацької діяльності. Це може бути або трудовий договір (якщо йдеться про сумісництво), або цивільно-правова угода (якщо йдеться про залучення особи як тренера до проведення тренінгів, майстер-класів, вебінарів тощо) ${ }^{19}$.

Наступними поняттям дослідження $€$ «викладацька діяльність». Викладацьку діяльність ми визначаємо як діяльність, що спрямована на формування компетентностей, розвиток світогляду, інтелектуальних і творчих здібностей, емоційно-вольових та/або фізичних якостей здобувачів вищої освіти. Як зазначають J. Cano-Hurtado, Carot-Sierra, M. Fernández-Prada end F. Fargueta у праці «An evaluation model of the teaching activity of academic staff» ${ }^{20}$ викладацьку діяльність можна визначити як групу процедур, які проводяться як всередині, так і поза межами аудиторії, що сприяють навчанню студентів відповідно до визначених цілей та рекомендацій освітніх програм та визначеному інституційному контексті.

Видами навчальних занять, які проводить викладач $є$ як традиційні - лекції, практичні, семінарські та

\footnotetext{
15 Про освіту : Закон України від 05.09.2017 № 2145-VIII. URL : https://zakon.rada.gov.ua/laws/show/2145-19.

16 Про вищу освіту : Закон України від 01.07.2014 № 1556-VII. URL : https://zakon.rada.gov.ua/laws/show/1556-18?find.

17 Класифікатор видів економічної діяльності (КВЕД ДК 009; 2010). URL : http://kved.ukrstat.gov.ua/KVED2010/kv10 i.html.

18 Державний класифікатор професій Держспоживстандарту України та ін. URL: https://buhgalter911.com/uk/spravochniki/ klassifikatory/statisticheskie-klassifikatory/klasifikator-profesiy-kp-950586.html.

19 Біла-Тіунова Л.Р., Хамходера О.П. Щодо визначення поняття «викладацька діяльність» у контексті антикорупційного законодавства. Науковий вісник Ужгородського національного університету. Серія: Право. 2017. Вип. 43. Т. 2. С. 28-32. URL : http://www.visnykjuris.uzhnu.uz.ua/file/No.43/part 2/6.pdf.

${ }^{20}$ Cano-Hurtado J.J., Carot-Sierra J.M., Fernández-Prada M.A., Fargueta F. An evaluation model of the teaching activity of academic staff. URL : https://www.oecd.org/education/imhe/43977296.pdf.
} 
лабораторні, так й інноваційні - семінари-практикуми, семінари-наради, семінари-тренінги, тренінги, вебінари, онлайн-курси, тематичні школи, «круглі столи» тощо, на яких викладач може виконувати роль модератора, фасилітатора, консультанта, тьютора, тренера тощо.

Наступним об'єктом нашого дослідження є поняття «науково-педагогічний потенціал університету». У «Великому тлумачному словнику сучасної української мови» ${ }^{21}$ визначено, що «потенціал» - це сукупність усіх наявних засобів, можливостей, продуктивних сил і т. ін., що можуть бути використані в якій-небудь галузі, ділянці, сфері. // Запас чого-небудь; резерв. // Приховані здатності, сили для якої-небудь діяльності, що можуть виявитися за певних умов.

У «Сучасному словнику іншомовних слів» ${ }^{22}$ потенціал визначається як сукупність наявних засобів, можливостей у певній галузі тощо. Тобто в обох визначеннях наголошується, що потенціал - це наявність прихованих можливостей, тобто того, що є в наявності, проте ще не розкрило себе із різних причин. Проте, на нашу думку, поняття «потенціал» це не тільки характеристика можливостей, але й вираження дійсності, наявності реальних властивостей.

О. Арзамасова у праці «Дефініція «кадровий потенціал»: дослідження сутності» ${ }^{23}$, зазначає, що «потенціал є динамічною системою, що об'єднує в собі три рівня зав'язків часу і простору, що функціонують в єдності. Ці зв'язки детермінують прояв потенціалу в різних формах. По-перше, потенціал характеризує минуле. У цьому випадку він виступає як «ресурс», оскільки втілює у собі накопичені системою характеристики, що дозволяють їй функціонувати. По-друге, він відображає сьогодення, тобто реально використовувані, або невживані наявні здібності. У даному випадку «потенціал» близький за значенням терміну «резерв». По-третє, він спрямований на майбутнє, тобто постійно змінюється, розвивається, накопичує нові здібності, характеристики, включаючи елементи майбутнього розвитку» ${ }^{24}$

Подібну думку щодо сутності потенціалу висловлює К. Липовська у праці «/нтелектуальний потенціал» у контексті управління суспільним розвитком: поняття та сутність» 25 , наголошуючи, що він відображає одночасно три рівні зв'язків і відносин.

Проте, на нашу думку, потенціал відображає два рівні часово-просторових зв'язків, перший - це ресурси, які $є$ результатом діяльності минулого та сьогодення, i, другий - можливості, тобто ті здібності і зв'язки, що орієнтовані на майбутнє.

Поділяємо думку $К$. Липовської ${ }^{26}$, що «досліджуючи «потенціал» будь-якого цілісного утворення (будь то особистість, громада, соціальна спільнота і т. д.) предметом вивчення стає не тільки сам об'єкт як такий, а одночасно й параметри того конкретного соціального середовища, в якому здійснюється його життєдіяльність» ${ }^{27}$. Тому досліджуючи проблему розвитку потенціалу викладачів університетів необхідно досліджувати ресурси, умови науково-освітнього середовища самого університету.

Ґрунтовний аналіз проблеми потенціалу університету подано у дисертаційному дослідженні О. Слюсаренко «Розвиток найвищого університетського потенціалу в умовах глобалізації: аналіз світового досвіду» ${ }^{28}$. Науковець пропонує наступне визначення « «університетського потенціалу» структурно системне поєднання ... освітнього, дослідницького, інноваційного, комунікативного потенціалів розвитку, а функціонально - здатністю, спроможністю, внутрішнім ресурсом здійснення місії університету» 29.

А. Печенюк ${ }^{30}$ у праці «Науково-педагогічний потенціал вищої освіти України: тенденції формування

\footnotetext{
21 Великий тлумачний словник сучасної української мови: 250000 / уклад. та голов. ред. В.Т. Бусел. Київ; Ірпінь : Перун, 2005.1728 с.

22 Пустовіт Л.О., Скопненко О.І., Сюта Г.М., Цимбалюк Т.В. Сучасний словник іншомовних слів. К. : Довіра. 2000. 670 с.

${ }^{23}$ Арзамасова О.В. Дефініція «кадровий потенціал»: дослідження сутності. Збірник наукових праць. Миколаїв, МнУ. 2015. Вип. 4. C. $102-106$.

${ }^{24}$ Арзамасова О.В. Дефініція «кадровий потенціал»: дослідження сутності. Збірник наукових праць. Миколаїв, МнУ. 2015. Вип. 4. C. 104.

25 Липовська К. «Інтелектуальний потенціал» у контексті управління суспільним розвитком: поняття та сутність. Державне управління та місцеве самоврядування. 2017. Вип. 4 (35). С. 21-27. URL : http://www.dridu.dp.ua/vidavnictvo/2017/2017 04(35)/5.pdf.

26 Липовська К. «Інтелектуальний потенціал» у контексті управління суспільним розвитком: поняття та сутність. Державне управління та місцеве самоврядування. 2017. Вип. 4 (35). С. 21-27. URL : http://www.dridu.dp.ua/vidavnictvo/2017/2017 04(35)/5.pdf

27 Липовська К. «Інтелектуальний потенціал» у контексті управління суспільним розвитком: поняття та сутність. Державне управління та місцеве самоврядування. 2017. Вип. 4 (35). С. 23. URL : http://www.dridu.dp.ua/vidavnictvo/2017/2017_04(35)/5.pdf.

${ }_{28}$ Слюсаренко О.М. Розвиток найвищого університетського потенціалу в умовах глобалізації: аналіз світового досвіду : дис. д-ра пед. наук : 13.00.06. Київ, 2015. 435 c. URL : http://umo.edu.ua/images/content/spec rada/dasertacii/Дисертація_фінал_Слюсаренко.pdf.

${ }^{29}$ Слюсаренко О.М. Розвиток найвищого університетського потенціалу в умовах глобалізації: аналіз світового досвіду : дис. д-ра пед. $\begin{array}{llllll}\text { наук } & \text { 13.00.06. } & \text { Kиїв, } & 2015 . & 435 \text { c. } & \text { C. } 56 .\end{array}$
} http://umo.edu.ua/images/content/spec rada/dasertacii/Дисертація фінал Слюсаренко.pdf.

30 Печенюк А. Науково-педагогічний потенціал вищої освіти України: тенденції формування та ефективності використання. Професійна 
ma ефективності використання» ${ }^{31}$ досліджує науково-педагогічний потенціал “...через кількісні та якісні характеристики науково-педагогічних працівників за категоріями осіб із науковими ступенями та вченими званнями, а також резерв зростання їх кількості внаслідок професійного розвитку, від результатів діяльності яких залежить конкурентоспроможність вищого навчального закладу на ринку освітніх послуг» ${ }^{32}$. Проте, на нашу думку, кваліфікаційний потенціал і кадровий резерв $є$ лише фрагментом феномену «науковопедагогічного потенціалу» тому аналіз винятково за вказаними показниками не розкривають усю сутність досліджуваного явища.

Г. Гузенко у праці «Людський потенціал: сутність та пріоритетні напрямки розвитку в Україні» ${ }^{33}$, стверджує, що потенціал, «...можна розглядати як сукупну здатність до освоєння і накопичення знань, створення інтелектуальних продуктів та ефективного використання інформації» ${ }^{34}$.

О. Ярошенко у праці «Науково-педагогічний потенціал університету як предмет наукового дискурсу» ${ }^{35}$ прийшла до висновку, що «...незважаючи на ... строкатість і різний об'єм, ... досліджуваного понятя. Він охоплює: кадровий потенціал університету, матеріально-технічні й інформаційні ресурси викладання, навчання і досліджень; мережу структурних підрозділів, що забезпечують підготовку здобувачів вищої освіти і дослідницьку діяльність науково-педагогічних працівників; освітні й управлінські інновації університету, обсяг і рівень наукових результатів та освітніх послуг; канали і механізми внутрішньої і зовнішньої комунікації, результати інтеграції у світовий освітньо-науковий простір; публікаційну активність суб'єктів освітнього процесу» ${ }^{36}$. У даному трактуванні, науковцем до науково-педагогічного потенціалу університету включено інформаційні, інтелектуальні, нематеріальні та матеріальні активи.

С. Калашнікова у праці «Розбудова інституційної спроможності та розвиток лідерського потенціалу закладів вищої освіти» ${ }^{37}$ наголошує, на доцільності впровадження у вищу освіту нової парадигми - розподіленого лідерства. «Модель розподіленого лідерства пропонує переосмислення потенціалу академічної спільноти з акцентом на колегіальність, громадянську активність та активність громади» ${ }^{38}$.

На основі аналізу наукових джерел встановлено, що основними сутнісними характеристиками різних видів потенціалу є інтелектуальний, емоційний та духовний компоненти. Інтелектуальний компонент - це спроможність розвивати, творити, нагромаджувати та використовувати знання, проєкти, ідеї, інтелектуальну власність; емоційний - спроможність використовувати і розвивати індивідуальні та соціально-психологічні якості, характеристики; духовний - спрямованість на розвиток вищих духовних ідеалів, цінностей та смислів.

Враховуючи вищезазначене, ми вважаємо, що розвиток потенціалу викладачів може здійснюватися як на особистісному, так і на інституційному рівні за компонентами:

1. Інтелектуальний:

орієнтація та підготовка кадрів. Україна: аспекти праці. 2013. № 4. С. 22-27. URL : http://nbuv.gov.ua/UJRN/Uap 2013 4 6.

31 Печенюк А. Науково-педагогічний потенціал вищої освіти України: тенденції формування та ефективності використання. Професійна орієнтація та підготовка кадрів. Україна: аспекти праці. 2013. № 4. C. 22-27. URL: http://nbuv.gov.ua/UJRN/Uap 2013 4 6.

32 Печенюк А. Науково-педагогічний потенціал вищої освіти України: тенденції формування та ефективності використання. Професійна орієнтація та підготовка кадрів. Україна: аспекти праці. 2013. № 4. C. 22. URL: http://nbuv.gov.ua/UJRN/Uap 2013 4 6.

33 Гузенко Г.М. Людський потенціал: сутність та пріоритетні напрямки розвитку в Україні. Збірник наукових праць Харківського начіонального педагогічного університеmу імені Г.С. Сковороди. Економіка. 2010. Bип. $10 . \quad$ C. $30-41 . \quad$ URL: http://nbuv.gov.ua/UJRN/znpkhnpu eko 2010108.

з4 Гузенко Г.М. Людський потенціал: сутність та пріоритетні напрямки розвитку в Україні. Збірник наукових праць Харківського національного педагогічного університеmу імені Г.С. Сковороди. Економіка. $2010 . \quad$ Вип. $10 . \quad$ C. $33 . \quad$ URL: http://nbuv.gov.ua/UJRN/znpkhnpu_eko_2010_10_8.

35 Ярошенко О. Науково-педагогічний потенціал університету як предмет наукового дискурсу. Неперервна професійна освіта: теорія і практика. Серія: Педагогічні науки. 2020. Вип. 2 (63). С. 7-13.

36 Ярошенко О. Науково-педагогічний потенціал університету як предмет наукового дискурсу. Неперервна професійна освіта: теорія і практика. Серія: Педагогічні науки. 2020. Вип. 2 (63). С. 7-13. С. 11.

37 Калашнікова С. Розбудова інституційної спроможності та розвиток лідерського потенціалу закладів вищої освіти: Оптимальні шляхи та моделі розвитку інституційного потенціалу університетів в контексті глобального лідерства: методичні рекомендації. О. Боднарук, І. Драч, С. Калашнікова, О. Коваленко, С. Курбатов, Н. Невмержицька, О. Паламарчук, І. Прохор, В. Рябченко, Л. Червона. За заг. ред. С. Калашнікової. К : TOB «Видавничий дім «Плеяди», 2017.100 с. URL :

https://ihed.org.ua/wp-content/uploads/2018/09/Shlyahi rozv instituciyn_potencialu Univ IVO-Avtors-kolektiv 2017-100p.pdf.

38 Калашнікова С. Розбудова інституційної спроможності та розвиток лідерського потенціалу закладів вищої освіти: Оптимальні шляхи та моделі розвитку інституційного потенціалу університетів в контексті глобального лідерства: методичні рекомендації. О. Боднарук, І. Драч, С. Калашнікова, О. Коваленко, С. Курбатов, Н. Невмержицька, О. Паламарчук, І. Прохор, В. Рябченко, Л. Червона ; за заг. ред. С. Калашнікової. К. : TOB «Видавничий дім «Плеяди», 2017.100 c. URL : https://ihed.org.ua/wpcontent/uploads/2018/09/Shlyahi rozv instituciyn potencialu Univ IVO-Avtors-kolektiv 2017-100p.pdf. 
- професійні знання, уміння, навички;

- інтелектуальні, пізнавальні і творчі здібності;

- мислення, сприйняття, увага, пам'ять, уява тощо.

2. Емоційний:

- емоції;

- почуття;

- вольові якості;

- поведінкові якості.

3. Духовний:

- смисли;

- цінності;

- ідеали.

Отже, потенціал викладача університету $є$ динамічною системою, що об'єднує в собі два рівні просторово-часових зав'язків, що функціонують в єдності. Перший - це ресурси, які є результатом діяльності минулого та сьогодення, i, другий - можливості, тобто ті здібності і зв'язки, що орієнтовані на майбутній розвиток. 


\section{Аналіз наукових праць з проблеми розвитку викладачів університетів}

В умовах глобалізації рушійним джерелом розвитку суспільства є інтелектуальна діяльність, яка визначає стратегію і тактику соціально-економічного розвитку будь-якої країни ${ }^{39}$. Входження суспільства в «економіку знань» висуває підвищені вимоги до науково-педагогічного персоналу університетів. Оскільки, з одного боку, університет є осередком продукування нових знань, ідей та інновацій, із другого - здійснює їх передачу майбутнім фахівцям.

Аналіз наукових джерел засвідчив, що розвиток різних видів компетентностей науково-педагогічних працівників університетів висвітлено в дослідженнях Н. Дівінської ${ }^{40}$, О. Жабенка ${ }^{41}$, С. Калашнікової ${ }^{42}$ В. Муромець ${ }^{43}$, І. Регейло ${ }^{44}$, Ю. Скиби ${ }^{45 ;} 46$, Г. Чорнойван ${ }^{47}$, О. Ярошенко ${ }^{48}$ та ін.

Зміст і структуру викладацької компетентності подано у працях М. Криштанович ${ }^{49}$, M. Konumoвa $^{50}$, С. Мунтян ${ }^{51}$, л.Тархан ${ }^{52}$, л. Большаніної ${ }^{53}$ та ін.

Принципи розвитку викладачів університетів розкрита у працях M. Blašková, R. Blaško, E. Matuska, J. Rosak-Szyrocka ${ }^{54}$, В. Гриженко ${ }^{55}$, Н. Василенко ${ }^{56}$, л. Козак ${ }^{57}$, Т. Горохівська ${ }^{58}$ та ін.

Професійні ролі викладачів університетів та особливості їх професійної поведінки розкрито у наукових публікаціях R. Boyatzis ${ }^{59}$, J. Cano-Hurtado, J. Carot-Sierra, M. Fernández-Prada \& F. Fargueta ${ }^{60}$, C. Гвоздiŭ і

\footnotetext{
39 Манів С.3. Інтелектуальний потенціал: його суть та складові. Економіка та держава. 2009. № 6. C. 51. URL : www.economy.in.ua.

40 Дівінська Н.О. Роль іншомовної компетентності у професійній діяльності науково-педагогічного працівника. Історико-педагогічні студії : науковий часопис. Київ : Вид-во НПУ імені М.П. Драгоманова. 2018. Вип. 11-12. С. 43-45.

41 Жабенко О.В. Професійний розвиток науково-педагогічних працівників у галузевих університетах України. Молодий вчений. 2018. № 8 (60). С. 143-149.

42 Калашнікова С. Професійний розвиток керівників вищих навчальних закладів: аналіз провідного зарубіжного досвіду. Проблеми освіти. 2013. № 74. 4. 1. С. 11-22.

43 Муромець В.Г. Опис програми розвитку загальних компетентностей здобувачів третього (освітньо-наукового) рівня вищої освіти. Вісник Чернігівського національного педагогічного університету імені Т.Г. Шевченка. Серія: Педагогічні науки. 2018. № 45. С. $134-147$.

44 Регейло І.Ю. Фундаментальні цінності Європейського простору вищої освіти (2010-2018рр.): пріоритетні орієнтири діяльності
} науково-педагогічних працівників. Педагогічний прочес: теорія і практика. 2018. № 4 (63). С. 7-17.

${ }^{45}$ Скиба Ю. Досвід розроблення професійних стандартів науково-педагогічних працівників закладів вищої освіти Великої Британії. Освітологічний дискурс. 2018. № 3-4 (22-23). С. 283-298. URL : https://od.kubg.edu.ua/index.php/journal/article/view/547.

${ }^{46}$ Скиба Ю.А. SWOT-аналіз як інструмент виявлення науково-педагогічного потенціалу українських університетів. Освітологічний дискурс. 2020. Вип. 3. С. 86-109. URL : https://od.kubg.edu.ua/index.php/journal/article/view/737.

47 Чорнойван Г.П. Досвід вітчизняних закладів вищої освіти щодо створення умов кар'єрного зростання науково-педагогічних працівників. Актуальні питання підготовки майбутнього вчителя хімії: теорія і практика : зб. наук. праць. Вінниця : ТОВ «НіланЛТД», 2018. Вип. 5. С. 55-58.

48 Ярошенко О.Г. Дослідницька компетентність науково-педагогічного працівника і її розвиток в умовах інтеграції вищої освіти і науки. Проблеми освіти : зб. наук. пр. Вінниця : ТОВ «Нілан - лТД». 2018. Вип. 88. Ч. 2. С. 339-347.

49 Криштанович М.Ф. Зміст і сутність структури професійно-педагогічної компетентності викладача закладу вищої освіти. Інноваційна педагогіка. 2018. Вип. 4 (22). Т. 2. С. 21-24. URL : http://www.innovpedagogy.od.ua/archives/2018/4/part 2/4-2 2018.pdf.

50 Копытова Н.Е. Многомерная профессиональная деятельность преподавателя вуза: от функций к компетентностям. Вестник ТГУ. 2012. Вып. 10 (114). С. 103-112.

${ }^{51}$ Мунтян С.Г. Професійний профіль викладача іноземної мови в європейському освітньому просторі. Сучасні проблеми гуманітаристики: світоглядні пошуки, комунікативні та педагогічні стратегії : матеріали $\vee$ Всеукр. наук.-практ. конф. Рівне : РІКУП НАНУ, 2015. С. 264-266.

52 Тархан Л. Теоретичні і методичні основи формування дидактичної компетентності майбутніх інженерів-педагогів : автореф. дис. ... докт. пед. наук : спец. 13.00.04. К., 2008. 40 с.

53 Большанина Л.В. Профессиональная компетентность преподавателя вуза: критерии и направления. Концепт. 2016. № 58. С. 1-5. URL: http://e-koncept.ru/2016/76096.htm.

${ }^{54}$ Blašková M., Blaško R., Matuska E., Rosak-Szyrocka J. Development of Key Competences of University Teachers and Managers. Social and Behavioral Sciences. 2015. C. 187-196. URL : https://www.researchgate.net/publication/277949648_Development_of_Key_Competences of University Teachers and Managers.

55 Гриженко В.В. Принципи розвитку фахових компетентностей викладачів загальнотехнічних дисциплін професійної (професійнотехнічної) освіти в умовах методичної роботи. Вісник післядипломної освіти. Серія: Педагогічні науки. 2020. Bип. 10 (39). URL: http://umo.edu.ua/images/content/nashi vydanya/visnyk PO/10 39 2020/pedagog/Bulletin 1039 Pedagogika Victor Hryzhenko.pdf.

56 Василенко Н.В. Підготовка керівників загальноосвітніх навчальних закладів до інноваційної діяльності : монографія. Вінниця : Пп «ТД «Едельвейс і К», 2010. 224 с.

57 Козак Л.В. Принципи інноваційної професійної діяльності викладача вищої школи. Педагогіка. 2012. С. 88-97.

58 Горохівська Т.М. Принципи розвитку професійно-педагогічної компетентності викладача вищої школи. Інноваційна педагогіка. 2019. Вип. 15. Т. 2. С. 44-51. URL : http://www.innovpedagogy.od.ua/archives/2019/15/part 2/15-2 2019.pdf.

${ }^{59}$ Boyatzis R. The competent manager. New York : Wiley, 2005. 406 p.

${ }^{60}$ Cano-Hurtado J.J., Carot-Sierra J.M., Fernández-Prada M.A., Fargueta F. An evaluation model of the teaching activity of academic staff. URL : https://www.oecd.org/education/imhe/43977296.pdf. 


\section{Принципи розвитку потенціалу викладачів університету в контексті розширення інституційної автономії}

Принцип (лат. principium - початок, основа) розуміють як основу певної сукупності фактів або знань; засади, з яких необхідно виходити та якими варто керуватися в різних сферах людської діяльності ${ }^{62}$. Словник української мови поняття «принцип» тлумачить як основне, вихідне положення; особливість, правило, покладене в основу створення або здійснення чого-небудь ${ }^{63}$. Як елемент педагогічної системи принципи впливають на формування змісту, вибір методів, застосування засобів, форм, на реалізацію педагогічної технології, а також визначають характер взаємовідносин між учасниками педагогічного процесу. Педагогічні принципи є своєрідним містком, який поєднує теорією з практикою і забезпечують досягнення педагогічних цілей.

За останні два десятиліття європейська вища освіта успішно зазнала фундаментальної зміни на системному та інституційному рівнях, пов'язані з національними реформами, Болонським процесом та ініціативами Європейського Союзу. Як результат, удосконалення профілю викладача та пошуку інноваційних технологій та практик, зміцнення зв'язку між освітою та науковими дослідженнями, сприяння розвитку використання нових технологій для викладання та навчання: ці теми стоять на порядку денному і обговорюються та активно досліджуються на національному та інституційному рівнях.

Задля підтримки процесу вдосконалення навчання і викладання в європейських університетах, заохочення та сприяння обміну і співробітництву у сфері вищої освіти серед університетів та між національними і загальноєвропейськими ініціативами запропоновано набір 3 десяти Принципів вдосконалення навчання та викладання ${ }^{64}$. Ці принципи насамперед передбачають переосмислення навчальної місії університету та орієнтовані на інституційних лідерів, які працюють з науково-педагогічними працівниками, студентами й зовнішніми зацікавленими сторонами для забезпечення якості, актуальності та привабливості вищої освіти. Вони також сприяють цінності Європейського простору вищої освіти (ЄПВО) та охоплюють Стандарти і рекомендації щодо забезпечення якості в європейському просторі вищої освіти (ESG) ${ }^{65}$. Запропоновані принципи спрямовані на постійне вдосконалення розвитку потенціалу викладачів та залучення університетської спільноти до забезпечення та підвищення якості навчання та викладання ${ }^{66}$.

Ураховуючи, що принципи в сучасній педагогічній науці розглядаються як спосіб досягнення педагогічних цілей з урахуванням відповідних підходів і умов ${ }^{67}$, нами визначено такі принципи розвитку потенціалу викладачів університетів:

- системності (розвиток потенціалу викладачів має розглядатися як сукупність взаємопов'язаних процесів зорієнтованих на підвищення якості навчання і викладання та його складових);

- безперервності (передбачає постійний розвиток потенціалу викладачів університетів відповідно до нової концепції «навчання впродовж життя»);

- ефективності (розвиток потенціалу викладачів зорієнтований на підвищення ефективності викладання і навчання);

- адаптивності (адаптація викладачів до мінливих, динамічних умов зовнішнього і внутрішнього середовища та можливість ефективно здійснювати освітній процес у нових умовах);

- повноти (виявлення і врахування всіх можливих інструментів розвитку потенціалу викладачів університетів);

- гнучкості (можливість розвитку потенціалу викладачів використовуючи різни стратегії, види,

\footnotetext{
61 Гвоздій С., Устянська О. Професійні ролі викладача вищої школи у підготовці майбутнього фахівця. Освітологічний дискурс. 2019. № 1-2. C. 141-160. URL : https://od.kubg.edu.ua/index.php/journal/article/view/555.

62 Философская энциклопедия / под редакцией Ф.В. Константинова. URL : http://philosophy.niv.ru.

${ }^{63}$ Словник української мови. Академічний тлумачний словник. URL : http://sum.in.ua.

${ }^{64}$ Європейські принципи вдосконалення навчання та викладання. URL: $\underline{\text { https://ihed.org.ua/wp- }}$ content/uploads/2020/12/yevropeiski_pryntsypy_vdoskonalennia_navchanya.pdf.

65 Європейські принципи вдосконалення навчання та викладання. URL: https://ihed.org.ua/wpcontent/uploads/2020/12/yevropeiski_pryntsypy_vdoskonalennia_navchanya.pdf.

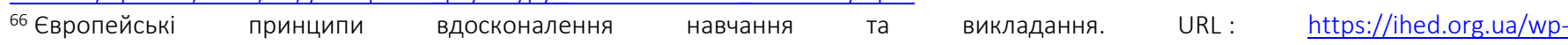
content/uploads/2020/12/yevropeiski pryntsypy vdoskonalennia navchanya.pdf.

67 Гончаренко С.М. Педагогічні закони, закономірності, принципи: сучасне тлумачення. Рівне : Вид-во «Волинські обереги», 2012. 192 c.
} 
форми і методи викладання);

- мотивації (стимулювання внутрішніх мотивів інтересів, потреб, прагнень викладачів до підвищення ефективності викладання і навчання та винагорода за значні досягнення);

- рефлексії (переосмислення власної викладацької діяльності, зокрема стратегії, технології, методів і засобів викладання і навчання в пошуках нових підходів до удосконалення ефективного викладання навчання).

Отже, принципами розвитку потенціалу викладачів університетів у контексті розширення інституційної автономії є: системність, безперервність, ефективність, адаптивність, повнота, гнучкість, мотивація і рефлексія. Впровадження зазначених принципів розвитку потенціалу викладачів університетів сприятиме удосконаленню профілю викладання та пошуку інноваційних технологій та практик, зміцненню зв'язку між освітою та науковими дослідженнями, розвитку використання нових технологій для викладання та навчання і забезпечить досягнення педагогічних цілей з урахуванням відповідних підходів і умов.

\section{Структура викладацької метакомпетентності науково-педагогічних працівників університетів}

Аналіз вітчизняних і зарубіжних джерел свідчить, що поняття «викладацька компетентність» $\epsilon$ відносно новим явищем в педагогічні теорії і практиці. Близькими за змістом до викладацької компетентності, що широко використовуються у публікаціях вітчизняних авторів $є$ професійно-педагогічна компетентність викладача університету, яка нами обрана для аналізу.

Різні підходи науковців М. Криштанович ${ }^{68}$, Л. Большанінової ${ }^{69}$, Г. Кошонько ${ }^{70}$, С. Мунтян ${ }^{71}$, Л. Тархан ${ }^{72}$, Янг і Шоу ${ }^{73}$, M. Blašková, R. Blaško, M. Jankalová, J. Radoslav ${ }^{74}$, N. Preeti ${ }^{75}$ до структури викладацької компетентності подано у табл. 1.

Таблиия 1

\section{Узагальнений перелік складових викладацької компетентності}

\begin{tabular}{|c|c|c|c|c|c|c|c|c|}
\hline Компетентності & 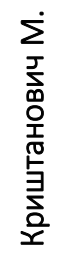 & 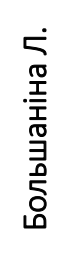 & 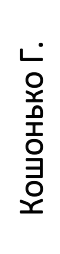 & 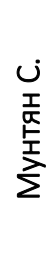 & 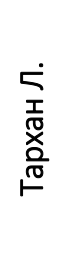 & 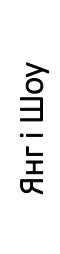 & 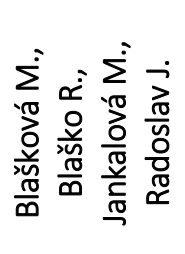 & 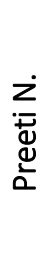 \\
\hline Навчально-методична & & $\checkmark$ & $\checkmark$ & $\checkmark$ & $\checkmark$ & $\checkmark$ & & \\
\hline Управлінська & $\checkmark$ & & $\checkmark$ & & $\checkmark$ & $\checkmark$ & & $\checkmark$ \\
\hline Рефлексивна & & $\checkmark$ & $\checkmark$ & & $\checkmark$ & $\checkmark$ & & \\
\hline Комунікативна & $\checkmark$ & & $\checkmark$ & & $\checkmark$ & $\checkmark$ & $\checkmark$ & $\checkmark$ \\
\hline Інформаційна & $\checkmark$ & & $\checkmark$ & & & & & \\
\hline Психологічна & $\checkmark$ & & $\checkmark$ & & & $\checkmark$ & & $\checkmark$ \\
\hline Загальнокультурна & & & $\checkmark$ & & $\checkmark$ & & $\checkmark$ & \\
\hline
\end{tabular}

68 Криштанович М.Ф. Зміст і сутність структури професійно-педагогічної компетентності викладача закладу вищої освіти. Інноваційна педагогіка. 2018. Вип. 4 (22). Т. 2. С. 21-24. URL : http://www.innovpedagogy.od.ua/archives/2018/4/part_2/4-2_2018.pdf.

69 Большанина Л.В. Профессиональная компетентность преподавателя вуза: критерии и направления. Концепт. 2016. № 58. С. 1-5. URL : http://e-koncept.ru/2016/76096.htm.

70 Кошонько Г. Сутність та структура професійної компетентності педагога. Теорія і практика професійної підготовки фрахівців у контексті загальноєвропейських інтеграційних процесів : зб. наук. пр. Житомир : ФОП Левковець, 2016. С. 30-37.

${ }^{71}$ Мунтян С.Г. Професійний профіль викладача іноземної мови в європейському освітньому просторі. Сучасні проблеми гуманітаристики: світоглядні пошуки, комунікативні та педагогічні стратегії : матеріали $\vee$ Всеукр. наук.-практ. конф. Рівне РІКУП НАНУ, 2015. С. 264-266.

72 Тархан Л. Теоретичні і методичні основи формування дидактичної компетентності майбутніх інженерів-педагогів : автореф. дис. ... докт. пед. наук : спец. 13.00.04. К., 2008. С. 17

73 Цитовано за Nair P. A Study on Identifying Teaching Competencies and Factors Affecting Teaching Competencies with Special. A Thesis submitted to Gujarat Technological University for the Award of Doctor of Philosophy in Management / Gujarat Technological University. Ahmedabad. 2017

74 Blašková M., Blaško R., Jankalová M., Radoslav J. Key Personality Competences of University Teacher: Comparison of Requirements Defined by Teachers and/Versus Defined by Students. Procedia - Social and Behavioral Sciences. February 2014. C. 466-475. URL: https://www.researchgate.net/publication/272703344 Key Personality Competences of University Teacher Comparison of Requiremen ts Defined by Teachers andVersus Defined by Students.

${ }^{75}$ Nair P. A Study on Identifying Teaching Competencies and Factors Affecting Teaching Competencies with Special. A Thesis submitted to Gujarat Technological University for the Award of Doctor of Philosophy in Management. Gujarat Technological University. Ahmedabad. 2017. 


\begin{tabular}{|c|c|c|c|c|c|c|c|c|}
\hline Самоосвітня & & $\checkmark$ & $\checkmark$ & & & & $\checkmark$ & $\checkmark$ \\
\hline Міжпредметна & & & & $\checkmark$ & $\checkmark$ & & & \\
\hline Професійна & & & & $\checkmark$ & $\checkmark$ & & $\checkmark$ & \\
\hline Соціально-педагогічна & & & & & $\checkmark$ & & & \\
\hline Дидактична & & & & & $\checkmark$ & $\checkmark$ & & \\
\hline Ціннісна & & & & & & $\checkmark$ & $\checkmark$ & \\
\hline Мотиваційна & & $\checkmark$ & & & & $\checkmark$ & $\checkmark$ & \\
\hline Організаційна & & & & & & $\checkmark$ & & $\checkmark$ \\
\hline Практично-діяльнісна & & $\checkmark$ & & & & & & \\
\hline Економіко- правова & $\checkmark$ & & & & & & & \\
\hline Екологічна & $\checkmark$ & & & & & & & \\
\hline Методично-інформаційна & & & & & $\checkmark$ & & & \\
\hline Науково-дослідницька & & & & & $\checkmark$ & & $\checkmark$ & \\
\hline Науково-методична & & & $\checkmark$ & & & & & \\
\hline Прогностична & & & $\checkmark$ & & & & & \\
\hline Методологічна & $\checkmark$ & & & & & & & \\
\hline Громадянська & & & $\checkmark$ & & & & & \\
\hline Соціальна & & & $\checkmark$ & & & & & \\
\hline Технологічна & & & $\checkmark$ & & & & & \\
\hline Підприємницька & & & $\checkmark$ & & & & & \\
\hline Спеціальна & & & & & $\checkmark$ & & & \\
\hline Емпатійна & & & & & & $\checkmark$ & & \\
\hline Морально-етична & & & & & & & $\checkmark$ & $\checkmark$ \\
\hline Критичне мислення & & & & & & & $\checkmark$ & $\checkmark$ \\
\hline Педагогічна & & & & & & & $\checkmark$ & \\
\hline Аналітична & & & & & & & & $\checkmark$ \\
\hline Інформаційна & & & & & & & & $\checkmark$ \\
\hline Емоційна & & & & & & & & $\checkmark$ \\
\hline Адаптивна & & & & & & & & $\checkmark$ \\
\hline
\end{tabular}

Аналіз даних табл. 1 свідчить, що викладацька компетентність включає значну кількість компетентностей. Тому в подальшому викладацьку компетентність ми розглядаємо як викладацьку метакомпетеність. Як видно з табл. 1 спільними у працях вищезазначених науковців $є:$ навчальнометодична, управлінська, рефлексивна, комунікативна, інформаційна, психологічна, загальнокультурна, самоосвітня, міжпредметна, професіоналізація компетентності. Частково спільними - науково-дослідницька, науково-методична, прогностична, методологічна, громадянська, соціальна, технологічна, підприємницька, спеціальна та емпатійна компетеність. Одинично представленим - прогностична, методологічна, громадянська, соціальна, технологічна, підприємницька, спеціальна, емпатійна. На нашу думку, поява нових компетентностей $є$ результатом розвитку і вдосконалення освітнього процесу в університетах.

Отже, складовими викладацької метакомпетентності можуть бути поліфункціональні та монофункціональні компетентності. Перша група компетентностей наприклад: навчально-методична, соціально-педагогічна, практично-діяльнісна, методично-інформаційна тощо охоплюють багато видів викладацької діяльності, що ускладнює процес діагностування рівня її сформованості. Компетентності другої групи відповідають конкретному виду викладацької діяльності, що дає можливість здійснити їі діагностику та розробити індивідуальну траєкторію розвитку викладацької метакомпетентності.

Здійснивши узагальнення наукових джерел та враховуючи власний багаторічний досвід науковопедагогічної діяльності нами виділено такі компетентності у структурі викладацької метакомпетентності:

- прогностична;

- проектувальна;

- предметна;

- інноваційна;

- педагогічного партнерства;

- організаційна;

- інформаційно-цифрова; 
- рефлексивна;

- мовно-комунікативна;

- інклюзивна;

- мотиваційна;

- здоров'язбережувальна;

- емоційно-етична;

- оцінювально-аналітична.

Взявши за основу розроблений нами «Професійний профіль науково-педагогічного працівника університету» ${ }^{76}$ визначено відповідність між компетентностями та видам викладацької діяльності (див. табл. 2).

Табличя 2

Компетентності та їх відповідність видам викладацької діяльності

\begin{tabular}{|c|c|}
\hline Компетентність & Вид викладацької діяльності \\
\hline \multirow[t]{3}{*}{ Прогностична } & Планувати послідовність викладу змісту і засвоєння знань студентами \\
\hline & Визначати мету і завдання навчальної дисципліни/курсу \\
\hline & $\begin{array}{l}\text { Встановлювати навчальні цілі, які забезпечують досяжні завдання для студентів із різними } \\
\text { особистісними здібностями }\end{array}$ \\
\hline \multirow[t]{4}{*}{ Проектувальна } & Розробляти навчальний план \\
\hline & Складати структурно логічну схему викладання навчальної дисципліни \\
\hline & Складати структурно логічну схему викладання освітньої програми \\
\hline & Визначати мету і завдання освітньої програми \\
\hline \multirow[t]{7}{*}{ Предметна } & Використовувати теоретичні зання в освітньому процесі \\
\hline & Використовувати в освітньому процесі розроблені навчальні матеріали \\
\hline & Використовувати в освітньому процесі різні форми, методи, технології і засоби навчання \\
\hline & Використовувати ефективні стратегії викладання і навчання \\
\hline & $\begin{array}{l}\text { Просувати новітні педагогічні знання за допомогою теоретичних, емпіричних і/або } \\
\text { трансляційних досліджень }\end{array}$ \\
\hline & $\begin{array}{l}\text { Добирати доцільні методи, засоби і форми навчання відповідно мети і завдань заняття із } \\
\text { врахуванням специфіки змісту навчального матеріалу, індивідуальних потреб студентів }\end{array}$ \\
\hline & Здійснювати освітній процес \\
\hline Інноваційна & Розробляти нові ефективні стратегії викладання і навчання \\
\hline $\begin{array}{l}\text { Педагогічного } \\
\text { партнерства }\end{array}$ & Використовувати різні стратегії залучення стейкхолдерів до освітнього процесу \\
\hline \multirow[t]{5}{*}{ Організаційна } & Розробляти та управляти інституційними стратегіями викладання і навчання \\
\hline & Керувати студентською групою під час проведення заняття \\
\hline & Забезпечувати своєчасність ознайомлення студентів з їхніми результатами навчання \\
\hline & Використовувати різні стратегій звітування студентами \\
\hline & Організовувати освітній процес \\
\hline Інформаційно-цифрова & $\begin{array}{l}\text { Використовувати відкриті ресурси, інформаційно-комунікаційні та цифрові технології в } \\
\text { освітньому процесі }\end{array}$ \\
\hline Рефлексивна & $\begin{array}{l}\text { Самооцінювати результати застосування стратегій, технологій, методів і засобів } \\
\text { педагогічного впливу }\end{array}$ \\
\hline Мовно-комунікативна & $\begin{array}{l}\text { Використовувати словесні та невербальні комунікативні стратегії для залучення студентів } \\
\text { до навчання }\end{array}$ \\
\hline \multirow[t]{2}{*}{ Інклюзивна } & $\begin{array}{l}\text { Забезпечувати сприятливі умови в освітньому середовищі для кожного студента, залежно } \\
\text { від його індивідуальних потреб, можливостей, здібностей та інтересів }\end{array}$ \\
\hline & $\begin{array}{l}\text { Демонструвати лідерство щодо просування інклюзивної та підтримуючої культури, } \\
\text { провідного досвіду у викладанні і навчанні }\end{array}$ \\
\hline Мотиваційна & Вміти підтримувати активність студентів під час здійснення навчальної діяльності \\
\hline Здоров'язбережувальна & Використовувати стратегії підтримки студентського добробуту і безпеки \\
\hline
\end{tabular}

\footnotetext{
${ }^{76}$ Скиба Ю.А. Професійний профіль і кваліфікаційні рівні науково-педагогічних працівників університетів в умовах інтеграції вищої освіти і науки. Теоретичні основи і технологія професійного розвитку науково-педагогічних працівників університетів в умовах інтеграції вищої освіти і науки : монографія / авт. кол.: О.Г. Ярошенко, О.В. Жабенко, Ю.А. Скиба, Н.О. Дівінська, І.Ю. Регейло, Г.П. Чорнойван ; за ред. О.Г. Ярошенко. К. : Інститут вищої освіти НАПН України, 2019. С. 30-32. URL: https://ihed.org.ua/wpcontent/uploads/2020/04/Tehnologiya prof rozvitku pracivn VNZ Monogr IVO-2019-236p avtors-kolektiv.pdf.
} 


\begin{tabular}{|c|c|}
\hline & Здійснювати профілактичні заходи щодо збереження життя та здоров'я студентів \\
\hline \multirow[t]{2}{*}{ Емоційно-етична } & Керувати власними емоційними станами та усвідомлювати особисті відчуття й почуття \\
\hline & Забезпечення відповідального та етичного використання IKT у навчанні та викладанні \\
\hline \multirow[t]{4}{*}{$\begin{array}{l}\text { Оцінювально- } \\
\text { аналітична }\end{array}$} & $\begin{array}{l}\text { Використовувати стратегії оцінювання, включаючи неформальний, формальний, } \\
\text { діагностичний, формуючий і підсумкові підходи до оцінювання результатів навчання } \\
\text { студентів }\end{array}$ \\
\hline & Інтерпретувати оцінки результатів навчання студентів та зміни навчальної практики \\
\hline & Модерувати оцінювання результатів навчання студентів і здійснювати їх підтримку \\
\hline & Oб'e \\
\hline
\end{tabular}

У табл.2 подано перелік компетентностей (прогностична, проектувальна, предметна, інноваційна, педагогічного партнерства, організаційна, інформаційно-цифрова, рефлексивна, мовно-комунікативна, інклюзивна, мотиваційна, здоров'язбережувальна, емоційно-етична, оцінювально-аналітична), які відповідають певним видам викладацької діяльності. Запропоновані матеріали дають можливість встановити потреби викладачів щодо розвитку певних компетентностей викладацької метакомпетентності і, відповідно, ефективно вибудовувати індивідуальну траєкторії власного розвитку.

\section{Професійні ролі викладачів університетів}

Технологічна революція спричинює модернізацію існуючих видів діяльності або ж появу нових, що зумовлює трансформацію видів професійної діяльності викладачів університетів в умовах розширення інституційної автономії ${ }^{77}$.

На думку R. Boyatzis професійна компетентність персоналу - це набір моделей професійної поведінки, або соціальних ролей, які працівник використовує у рамках своєї посади для ефективного здійснення професійної діяльності ${ }^{78}$.

Як зазначають J.Cano-Hurtado, J.Carot-Sierra, M. Fernández-Prada, F. Fargueta ${ }^{79}$, викладацька діяльність передбачає виконання низки ролей, пов'язаних із плануванням та управлінням викладання, пошуком і впровадженням нових методів навчання, координацією освітньої діяльності, оцінюванням навчання студентів тощо.

С. Гвоздій, О.Устянська ${ }^{80}$, досліджуючи проблему розширення професійних ролей науковопедагогічних працівників встановили, що насамперед викладачі університетів активно освоюють такі професійні ролі як: викладач-тьютор, модератор, фасилітатор і куратор. Науковці викладачу-модератору пропонують використовувати прийоми, методи і форми організації пізнавальної діяльності спрямовані на активізацію аналітичної та рефлексивної діяльності студентів, розвиток дослідницьких і проектувальних умінь, комунікативних здібностей та навичок роботи в команді. Викладачу-фасилітатору стимулювати процес навчання, створювати інтелектуальну та емоційну обстановку, атмосферу психологічної підтримки. Викладачу-куратору створювати зовнішні умови і сприяти актуалізації внутрішніх резервів майбутнього фахівця для повноцінної творчої самореалізації як у професійній, так і в інших сферах життєдіяльності ${ }^{81}$.

J. Dengerink, M. Lunenberg i F. Korthagen ${ }^{82}$ зазначають, що «професійну роль викладача розглядають як особисту інтерпретацію тієї чи іншої позиції на основі очікувань від оточуючого середовища та систематично організованих та переданих знань» ${ }^{83}$. На основі аналізу значної кількості наукових статей із проблеми дослідження J. Dengerink, M. Lunenberg і F. Korthagen виокремлено такі професійні ролі викладачів:

\footnotetext{
77 Мирончук Н. Трансформація функціонально-професійної ролі викладача вищої школи в умовах соціокультурних змін. Митець культура - виміри часу : міжнародні наукові читання (Житомир, 2017) : зб. стат. ; ред.-упоряд. І.Є. Копоть. Житомир: Вид. O.О. Євенок, 2017. С. 377-387. URL: http://eprints.zu.edu.ua/25980/1/Мирончук НМ. Трансформація функц.профес.рол! викладача.pdf.

78 Boyatzis R. The competent manager. New York : Wiley, 2005. 406 p.

${ }^{79}$ Cano-Hurtado J.J., Carot-Sierra J.M., Fernández-Prada M.A., Fargueta F. An evalution model of the teaching activity of academic staff. URL : https://www.oecd.org/education/imhe/43977296.pdf.

80 Гвоздій С., Устянська О. Професійні ролі викладача вищої школи у підготовці майбутнього фахівця. Освітологічний дискурс. 2019. № 1-2. C. 141-160. URL : https://od.kubg.edu.ua/index.php/journal/article/view/555.

81 Гвоздій С., Устянська О. Професійні ролі викладача вищої школи у підготовці майбутнього фахівця. Освітологічний дискурс. 2019. № 1-2. C. 24-25. URL : https://od.kubg.edu.ua/index.php/journal/article/view/555.

82 Dengerink J., Lunenberg M. and Korthagen F. The Professional Teacher Educator: Six Roles. BEITRÄGE ZUR LEHRERINNEN- UND LEHRERBILDUNG. 2015. № 33 (3). URL : https://www.researchgate.net/publication/295869073.

83 Dengerink J., Lunenberg M. and Korthagen F. The Professional Teacher Educator: Six Roles. BEITRÄGE ZUR LEHRERINNEN- UND LEHRERBILDUNG. 2015. № 33 (3). URL : https://www.researchgate.net/publication/295869073.
} 
- дослідник,

- тренер,

- розробник освітньої програми,

- воротар,

- брокер.

Крім того, J. Dengerink, M. Lunenberg, F. Korthagen розкрито сутність визначених ролей, особливості поведінки та запропоновано шляхи підвищення їхньої компетентності відповідно до вищезазначених ролей ${ }^{84}$.

T. Brinker, S. Brendel, D. Ellinger, J.Gerber та ін. у праці «Rollen- und Kompetenzprofilefuer hochschuldidaktisch tatigee» ${ }^{55}$ виокремили такі професійні ролі викладача:

- організатор,

- розробник,

- дослідник,

- освітній менеджер,

- консультант / тренер,

- мережевик.

Кожна із визначених професійних ролей передбачає наявність необхідних компетентностей для ефективного здійснення освітнього процесу.

Л. Гурьє у праці «Технологии развития профессиональной компетентности преподавателя вуза» ${ }^{86}$ визначено такі ролі, що виконує викладач у процесі викладацької діяльності: організатор, оратор, методист, дидакт, педагогічний технолог, наставник, вихователь, куратор, дослідник і керівник ${ }^{87}$.

Узагальнення результатів аналізу вищезазначених наукових джерел щодо професійних ролей викладача університету подано у табл. 3.

Таблиця 3

Професійні ролі викладачів університету [88; 89;90;91]

\begin{tabular}{|c|c|c|c|c|}
\hline Професійна роль / Автори & $\begin{array}{c}\text { Гвоздій С., } \\
\text { Устянська О. }\end{array}$ & $\begin{array}{c}\text { Dengerink J., } \\
\text { Lunenberg M. and } \\
\text { Korthagen F. }\end{array}$ & $\begin{array}{c}\text { Brinker T., Brendel S., } \\
\text { Ellinger D., Gerber J. } \\
\text { та ін. }\end{array}$ & ГурьєЛ.І \\
\hline Тьютор & $\checkmark$ & & & \\
\hline Модератор & $\checkmark$ & & & \\
\hline Фасилітатор & $\checkmark$ & & & \\
\hline Куратор & $\checkmark$ & & & \\
\hline Викладач & & $\checkmark$ & & \\
\hline Дослідник & & $\checkmark$ & $\checkmark$ & $\checkmark$ \\
\hline Тренер & & $\checkmark$ & $\checkmark$ & \\
\hline Розробник & $\checkmark$ & $\checkmark$ & $\checkmark$ & $\checkmark$ \\
\hline Воротар & & $\checkmark$ & & \\
\hline Брокер & & $\checkmark$ & & \\
\hline
\end{tabular}

${ }^{84}$ Dengerink J., Lunenberg M. and Korthagen F. The Professional Teacher Educator: Six Roles. BEITRÄGE ZUR LEHRERINNEN- UND LEHRERBILDUNG. 2015. № 33 (3). URL : https://www.researchgate.net/publication/295869073.

85 Rollen- und Kompetenzprofilefuer hochschuldidaktisch rarbeitet von der Arbeitsgruppe Weiterbildung (AGWB) in der Deutschen Gesellschaft für Hochschuldidaktik (dghd). Tobina Brinker, Sabine Brendel, Dorothea Ellinger, Julia Gerber ... Überarbeitete und korrigierte Version. 2018. URL: https://www.dghd.de/wp-content/uploads/2018/02/Rollen- und Kompetenzprofile fuer hochschuldidaktisch Taetige final.pdf.

86 гурье Л.И. Технологии развития профессиональной компетентности преподавателя вуза : монография. Казань: РИЦ «Ш кола», 2010. 256 c. URL : https://moodle.kstu.ru/pluginfile.php/35335/mod resource/content/1/.pdf.

87 гурье Л.И. Технологии развития профессиональной компетентности преподавателя вуза : монография. Казань: РИЦ «Школа», 2010. C. 40. URL : https://moodle.kstu.ru/pluginfile.php/35335/mod resource/content/1/.pdf.

88 Гвоздій С., Устянська О. Професійні ролі викладача вищої школи у підготовці майбутнього фахівця. Освітологічний дискурс. 2019. № 1-2 (24-25). С. 141-160.

89 Dengerink J., Lunenberg M. and Korthagen F. The Professional Teacher Educator: Six Roles. BEITRÄGE ZUR LEHRERINNEN- UND LEHRERBILDUNG. 2015. № 33 (3). URL : https://www.researchgate.net/publication/295869073.

90 Rollen- und Kompetenzprofilefuer hochschuldidaktisch rarbeitet von der Arbeitsgruppe Weiterbildung (AGWB) in der Deutschen Gesellschaft für Hochschuldidaktik (dghd). Tobina Brinker, Sabine Brendel, Dorothea Ellinger, Julia Gerber ... Überarbeitete und korrigierte Version. 2018. URL: https://www.dghd.de/wp-content/uploads/2018/02/Rollen- und Kompetenzprofile fuer hochschuldidaktisch Taetige final.pdf.

91 Гурье Л.И. Технологии развития профессиональной компетентности преподавателя вуза : монография. Казань: РИЦ «Школа», 2010. 256 c. URL : https://moodle.kstu.ru/pluginfile.php/35335/mod resource/content/1/.pdf. 


\begin{tabular}{|l|l|l|l|l|}
\hline Організатор & & & $\checkmark$ & $\checkmark$ \\
\hline Освітній менеджер & & & $\checkmark$ & \\
\hline Консультант & & $\checkmark$ & $\checkmark$ & $\checkmark$ \\
\hline Мережевик & & & & $\checkmark$ \\
\hline Оратор & & & & $\checkmark$ \\
\hline Психолог & & & & $\checkmark$ \\
\hline Методист & & & & $\checkmark$ \\
\hline Дидакт & & & & $\checkmark$ \\
\hline Педагогічний технолог & & & & \\
\hline
\end{tabular}

На основі поданих у табл. 3 даних нами встановлено, що спільними в аналізованих наукових джерелах $€$ такі професійні ролі як наставник, розробник, консультант, дослідник. Водночас спостерігається поява нових професійних ролей, а саме: тьютор, модератор, фасилітатор, освітній менеджер, педагогічний технолог, мережевик та ін.

Узагальнивши наукові джерела з проблеми дослідження нами запропоновано перелік професійних ролей викладача університету із зазначенням компетентності та виду викладацької діяльності (див. табл. 4).

Професійні ролі викладача університету, компетентності та види діяльності

\begin{tabular}{|c|c|c|}
\hline $\begin{array}{l}\text { Професійна } \\
\text { роль }\end{array}$ & Компетентність & Вид викладацької діяльності \\
\hline \multirow[t]{3}{*}{ Розробник } & \multirow[t]{3}{*}{ Прогностична } & Планувати послідовність викладу змісту і засвоєння знань студентами \\
\hline & & Визначати мету і завдання навчальної дисципліни/курсу \\
\hline & & $\begin{array}{l}\text { Встановлювати навчальні цілі, які забезпечують досяжні завдання для студентів } \\
\text { із різними особистісними здібностями }\end{array}$ \\
\hline \multirow[t]{4}{*}{ Дизайнер } & \multirow[t]{4}{*}{ Проектувальна } & Розробляти навчальний план \\
\hline & & Складати структурно логічну схему викладання навчальної дисципліни \\
\hline & & Складати структурно логічну схему викладання освітньої програми \\
\hline & & Визначати мету і завдання освітньої програми \\
\hline \multirow{7}{*}{$\begin{array}{l}\text { Організатор } \\
\text { Супроводжувач } \\
\text { навчання } \\
\text { Тьютор } \\
\text { Коуч } \\
\text { Модератор } \\
\text { Фасилітатор } \\
\text { Новатор } \\
\text { Постачальник } \\
\text { зворотного } \\
\text { зв'язку }\end{array}$} & \multirow[t]{7}{*}{ Предметна } & Використовувати теоретичні знання в освітньому процесі \\
\hline & & Використовувати в освітньому процесі розроблені навчальні матеріали \\
\hline & & $\begin{array}{l}\text { Використовувати в освітньому процесі різні форми, методи, технології і засоби } \\
\text { навчання }\end{array}$ \\
\hline & & Використовувати ефективні стратегії викладання і навчання \\
\hline & & $\begin{array}{l}\text { Просувати новітні педагогічні знання за допомогою теоретичних, емпіричних } \\
\text { і/або трансляційних досліджень }\end{array}$ \\
\hline & & $\begin{array}{l}\text { Добирати доцільні методи, засоби і форми навчання відповідно мети і завдань } \\
\text { заняття із врахуванням специфіки змісту навчального матеріалу, індивідуальних } \\
\text { потреб студентів }\end{array}$ \\
\hline & & Використовувати різні стратегій звітування студентами \\
\hline \multirow{3}{*}{$\begin{array}{l}\text { Дослідник } \\
\text { Розробник }\end{array}$} & \multirow[t]{3}{*}{ Інноваційна } & Розробляти відповідні навчальні матеріали з дисципліни/курсу \\
\hline & & Розробляти нові ефективні стратегії викладання і навчання \\
\hline & & Розробляти різні стратегій звітування студентами \\
\hline Координатор & $\begin{array}{l}\text { Педагогічного } \\
\text { партнерства }\end{array}$ & $\begin{array}{l}\text { Використовувати різні стратегії залучення батьків та стейкхолдерів до освітнього } \\
\text { процесу }\end{array}$ \\
\hline \multirow{5}{*}{$\begin{array}{l}\text { Організатор } \\
\text { Коуч } \\
\text { Лідер } \\
\text { Тьютер } \\
\text { Модератор }\end{array}$} & \multirow[t]{5}{*}{ Організаційна } & Розробляти та управляти інституційними стратегіями викладання і навчання \\
\hline & & Керувати студентською групою під час проведення заняття \\
\hline & & $\begin{array}{l}\text { Забезпечувати своєчасність ознайомлення студентів з їхніми результатами } \\
\text { навчання }\end{array}$ \\
\hline & & Розробляти різні стратегій звітування студентами \\
\hline & & Здійснювати освітній процес \\
\hline \multirow[t]{2}{*}{ Мережевик } & $\begin{array}{l}\text { Інформаційно- } \\
\text { цифрова }\end{array}$ & $\begin{array}{l}\text { Використовувати відкриті ресурси, інформаційно-комунікаційні та цифрові } \\
\text { технології в освітньому процесі }\end{array}$ \\
\hline & Рефлексивна & $\begin{array}{l}\text { Самооцінювати результати застосування стратегій, технологій, методів і засобів } \\
\text { педагогічного впливу }\end{array}$ \\
\hline $\begin{array}{l}\text { Коуч } \\
\text { Тьютер } \\
\text { Модератор }\end{array}$ & $\begin{array}{l}\text { Мовно- } \\
\text { комунікативна }\end{array}$ & $\begin{array}{l}\text { Використовувати словесні та невербальні комунікаційні стратегії для залучення } \\
\text { студентів до навчання }\end{array}$ \\
\hline
\end{tabular}




\begin{tabular}{|c|c|c|}
\hline \multirow{2}{*}{$\begin{array}{l}\text { Коуч } \\
\text { Лідер } \\
\text { Тьютер } \\
\text { Модератор }\end{array}$} & \multirow[t]{2}{*}{ Інклюзивна } & $\begin{array}{l}\text { Забезпечувати сприятливі умови в освітньому середовищі для кожного } \\
\text { студента, залежно від його індивідуальних потреб, можливостей, здібностей та } \\
\text { інтересів }\end{array}$ \\
\hline & & $\begin{array}{l}\text { Здатність демонструвати лідерство щодо просування інклюзивної та } \\
\text { підтримуючої культури, провідного досвіду у викладанні і навчанні }\end{array}$ \\
\hline Мотиватор & Мотиваційна & $\begin{array}{l}\text { Вміти підтримувати активність студентів під час здійснення навчальної } \\
\text { діяльності }\end{array}$ \\
\hline \multirow{4}{*}{$\begin{array}{l}\text { Радник } \\
\text { Наставник }\end{array}$} & \multirow{2}{*}{$\begin{array}{l}\text { Здоров'язбере } \\
\text { жувальна }\end{array}$} & Використовувати стратегії підтримки студентського добробуту і безпеки \\
\hline & & $\begin{array}{l}\text { Здійснювати профілактичні заходи щодо збереження життя та здоров'я } \\
\text { студентів }\end{array}$ \\
\hline & \multirow[t]{2}{*}{$\begin{array}{l}\text { Емоційно- } \\
\text { етична }\end{array}$} & $\begin{array}{l}\text { Керувати власними емоційними станами та усвідомлювати особисті відчуття й } \\
\text { почуття }\end{array}$ \\
\hline & & $\begin{array}{l}\text { Забезпечувати відповідальне та етичне використання IKT у навчанні та } \\
\text { викладанні }\end{array}$ \\
\hline \multirow[t]{4}{*}{$\begin{array}{l}\text { Оцінювач } \\
\text { Аналітик } \\
\text { Модератор }\end{array}$} & \multirow[t]{4}{*}{$\begin{array}{l}\text { Оцінювально- } \\
\text { аналітична }\end{array}$} & $\begin{array}{l}\text { Використовувати стратегії оцінювання, включаючи неформальний, формальний, } \\
\text { діагностичний, формуючий і підсумкові підходи до оцінювання результатів } \\
\text { навчання студентів }\end{array}$ \\
\hline & & Інтерпретувати оцінки результатів навчання студента та навчальної практики \\
\hline & & $\begin{array}{l}\text { Модерувати оцінювання результатів навчання студентів і здійснювати їх } \\
\text { супровід }\end{array}$ \\
\hline & & Об'єктивно оцінювати вагомі досягнення студентів \\
\hline
\end{tabular}

Отже, для здійснення освітнього процесу викладачі університету мають володіти прогностичною, проектувальною, предметною, інноваційною, організаційною, інформаційно-цифровою, рефлексивною, мовно-комунікативною, інклюзивною, мотиваційною, здоров'язбережувальною, емоційно-етичною, оцінювально-аналітичною компетентностями та педагогічним партнерством. Вищезазначені професійні ролі (див. табл. 4) та пов'язана з ними професійна діяльність значно відрізняються. Ця різниця ще більше простежується під час аналізу компетентностей, якими мають володіти викладачі університету відповідно до нових професійних ролей. Ураховуючи появу нових професійних ролей викладачі університету потребують постійного вдосконалення свого професійного рівня. Здійснений аналіз дає підстави сформулювати тенденцію: збільшення видів викладацької діяльності вплинуло на розширення професійних ролей викладачів університету. 


\section{Висновки}

1. Отже, у досліджені подано авторське трактування поняття «викладач університету», «викладацька діяльність» і «потенціал викладача університету».

Викладач університету - особа, яка здійснює викладацьку діяльність в університеті, відповідає освітнім нормативним вимогам та зарахована до складу штатних працівників університету на основі відповідного трудового або цивільно-правового договору.

Викладацька діяльність - діяльність, яка спрямована на формування знань, інших компетентностей, світогляду, розвиток інтелектуальних і творчих здібностей, емоційно-вольових та/або фізичних якостей здобувачів освіти, яка здійснюється викладачем під час проведення традиційних (лекції, практичні, семінарські та лабораторні), так і інноваційні (семінари-практикуми, семінари-наради, семінари-тренінги, тренінги, вебінари, онлайн-курси, тематичні школи, «круглі столи» тощо) видів навчальних занять.

Потенціал викладача університету є динамічною системою, що об'єднує в собі два рівні зав'язків, що функціонують в єдності. Перший - це ресурси, які є результатом діяльності минулого та сьогодення, і, другий - можливості, тобто ті здібності і зв'язки, що орієнтовані на майбутнє які постійно змінюється, розвивається, накопичують нові здібності, характеристики, включаючи елементи майбутнього розвитку. Крім того, потенціал викладача університету можна розвивати як за рівнями (особистісний, інституційний), так і за компонентами (інтелектуальний, емоційний, духовний).

2. Обгрунтовано закономірність, визначено тенденції і наукові принципи розвитку викладачів університетів. Закономірність: чим більше в освітньому процесі університету впроваджується нових технологій і практик, тим більше зростає потреба у розширенні викладачами професійних компетентностей.

Визначено тенденції розвитку викладачів університетів:

- зміна існуючих та виникнення нових видів професійної діяльності викладача університету;

- спостерігається розширення інноваційних технологій та інструментів викладання і навчанні в університеті;

- поява нових професійних ролей потребує розвитку викладацької метакомпетентності.

Встановлено принципи розвитку потенціалу викладачів університетів:

- системності (розвиток потенціалу викладачів має розглядатися як сукупність взаємопов'язаних процесів зорієнтованих на підвищення якості навчання і викладання та його складових);

- безперервності (передбачає постійний розвиток потенціалу викладачів університетів відповідно до нової концепції «навчання впродовж життя»);

- ефективності (розвиток потенціалу викладачів зорієнтований на підвищенню ефективності викладання і навчання);

- адаптивності (адаптація викладачів до мінливих, динамічних умов зовнішнього та внутрішнього середовища та можливість ефективно здійснювати освітній процес в нових умовах);

- повноти (виявлення і врахування всіх можливих інструментів розвитку потенціалу викладачів);

- гнучкості (можливість розвитку потенціалу викладачів використовуючи різни стратегії, види, форми і методи викладання);

- мотивації (стимулювання внутрішніх мотивів інтересів, потреб, прагнень викладачів до підвищення ефективності викладання і навчання та винагорода за значні досягнення);

- рефлексії (переосмислення власної діяльності, зокрема стратегії, технології, методів і засобів викладання і навчання в пошуках нових підходів до удосконалення ефективного викладання і навчання).

3. Виявлено структурні компонентами викладацької компетентності: прогностична, проектувальна, предметна, інноваційна, педагогічного партнерства, організаційна та ін., які загалом охоплюють усі види викладацької діяльності.

4. Встановлено появу нових професійних ролей викладача університету, такі як тьютор, коуч, модератор, фасилітатор, новатор, координатор, мережевик та ін., які потребують володіння викладачами новими компетентностями. Враховуючи появу нових професійних ролей викладач університету потребує постійного вдосконалення свого професійного рівня відповідно до нових потреб.

Розвиток потенціалу викладачів впливає, загалом, на стан науково-педагогічний потенціалу університету забезпечуючи його конкурентоспроможність на ринку освітніх послуг. 


\section{Список використаних джерел}

1. Арзамасова О.В. Дефініція «кадровий потенціал»: дослідження сутності. Збірник наукових праць / Миколаївський національний університет імені В.О. Сухомлинського. Миколаїв, МНУ. 2015. Вип. 4. С. $102-106$.

2. Біла-Тіунова Л.Р., Хамходера О.П. Щодо визначення поняття «викладацька діяльність» у контексті антикорупційного законодавства. Науковий вісник Ужгородського національного університету. Серія Право. 2017. Вип. 43. T. 2. С. 28-32. URL : http://www.visnyk-juris.uzhnu.uz.ua/file/No.43/part_2/6.pdf.

3. Большанина Л.В. Профессиональная компетентность преподавателя вуза: критерии и направления. Кониепm. 2016. № 58. С. 1-5. URL : http://e-koncept.ru/2016/76096.htm.

4. Василенко Н.В. Підготовка керівників загальноосвітніх навчальних закладів до інноваційної діяльності : монографія. Вінниця : ПП «ТД «Едельвейс і К», 2010. 224 с.

5. Великий тлумачний словник сучасної української мови: 250000 / уклад. та голов. ред. В.Т. Бусел. Київ; Ірпінь : Перун, 2005. 1728 с.

6. Гацько А.Ф., Смігунова О.В. Емоційний інтелект як стратегічний важіль лідерства. Вісник Харківського національного технічного університету сільського господарства імені Петра Василенка. 2016. № 177. C. 61-67. URL : http://journals.uran.ua/index.php/wissn021/article/view/97816.

7. Гвоздій С., Устянська О. Професійні ролі викладача вищої школи у підготовці майбутнього фахівця. Освітологічний дискурс. 2019. № 1-2. С. 141-160. URL : https://od.kubg.edu.ua/index.php/journal/article/view/555.

8. Гончаренко С.М. Педагогічні закони, закономірності, принципи: сучасне тлумачення. Рівне: Вид-во «Волинські обереги», 2012. 192 с.

9. Горохівська Т.М. Принципи розвитку професійно-педагогічної компетентності викладача вищої школи. Інноваційна педагогіка. 2019. Вип. 15. Т. 2. С. 44-51. URL : http://www.innovpedagogy.od.ua/archives/2019/15/part_2/152 2019.pdf.

10. Гриженко В.В. Принципи розвитку фахових компетентностей викладачів загальнотехнічних дисциплін професійної (професійно-технічної) освіти в умовах методичної роботи. Вісник післядипломної освіти. Серія: Педагогічні науки. 2020. Вип. 10 (39). URL: http://umo.edu.ua/images/content/nashi vydanya/visnyk PO/10 39 2020/pedagog/ Bulletin 1039 Pedagogika Victor Hryzhenko.pdf.

11. Гузенко Г.М. Людський потенціал: сутність та пріоритетні напрямки розвитку в Україні. Збірник наукових праць Харківського національного педагогічного університету імені Г.С. Сковороди. Економіка. 2010. Вип. 10. С. 30-41. URL : http://nbuv.gov.ua/UJRN/znpkhnpu eko 2010108.

12. Гура Т.В. Лідерський потенціал як важлива складова педагогічної культури викладача технічного університету. Педагогіка формування творчої особистості у вищій і загальноосвітній школах. 2015. Вип. 44 (97). С. 418-428.

13. Гурье Л.И. Технологии развития профессиональной компетентности преподавателя вуза : монография. Казань : РИЦ «Школа», 2010. 256 с. URL : https://moodle.kstu.ru/pluginfile.php/35335/mod resource/content/1/.pdf.

14. Державний класифікатор професій Держспоживстандарту України ДК 003:2010. URL: https://buhgalter911.com/uk/spravochniki/klassifikatory/statisticheskie-klassifikatory/klasifikator-profesiy-kp-950586.html.

15. Європейські принципи вдосконалення навчання та викладання. URL: https://ihed.org.ua/wpcontent/uploads/2020/12/yevropeiski pryntsypy vdoskonalennia navchanya.pdf.

16. Дівінська Н.О. Роль іншомовної компетентності у професійній діяльності науково-педагогічного працівника. Історико-педагогічні студії : науковий часопис. Київ : Вид-во НПУ імені М.П. Драгоманова. 2018. Вип. 11-12. С. 43-45.

17. Жабенко О.В. Професійний розвиток науково-педагогічних працівників у галузевих університетах України. Молодий вчений. 2018. № 8 (60). С. 143-149.

18. Ілляшенко С.М. Інтелектуальний капітал ВНЗ як запорука його інноваційного розвитку: сутність, структура, підходи до оцінки. Маркетинг і менеджмент інновацій. 2011. № 1. С. 145-154.

19. Інтелектуальний потенціал та науково технічна політика / під наук. ред. академіка НАНУ Долішнього М.І. Львів : ІРД НАН України, 1999. 234 с.

20. Калашнікова С. Професійний розвиток керівників вищих навчальних закладів: аналіз провідного зарубіжного досвіду. Проблеми освіти. 2013. № 74. Ч. 1. С. 11-22.

21. Калашнікова С. Розбудова інституційної спроможності та розвиток лідерського потенціалу закладів вищої освіти: Оптимальні шляхи та моделі розвитку інституційного потенціалу університетів в контексті глобального лідерства: методичні рекомендації. О. Боднарук, І. Драч, С. Калашнікова, О. Коваленко, С. Курбатов, Н. Невмержицька, О. Паламарчук, І. Прохор, В. Рябченко, Л. Червона ; за заг. ред. С. Калашнікової. К. : ТОВ «Видавничий дім «Плеяди», 2017. 100 c. URL : https://ihed.org.ua/wp-content/uploads/2018/09/Shlyahi rozv instituciyn potencialu Univ IVO-Avtorskolektiv 2017-100p.pdf.

22. Калашнікова С.А. Розвиток лідерського потенціалу університетів: теоретичні основи. Аналіз провідного вітчизняного та зарубіжного досвіду розвитку лідерського потенціалу університетів у контексті глобального лідерства (частинна I) : препринт (аналітичні матеріали) ; за заг. ред. С. Калашнікової. К. : Інститут вищої освіти НАПН України. 2015. 153 с. URL: https://ihed.org.ua/wp-content/uploads/2018/09/Analiz dosvidu rozvitku lider- 
potenc UNIVERs ch1 2015 153p IBO avtors-kolektiv.pdf.

23. Класифікатор видів економічної

http://kved.ukrstat.gov.ua/KVED2010/kv10 i.html.

діяльності КВЕД ДК 009; 2010). URL:

24. Козак Л.В. Принципи інноваційної професійної діяльності викладача вищої школи. Педагогіка. 2012. С. 88-97.

25. Копытова Н.Е. Многомерная профессиональная деятельность преподавателя вуза: от функций к компетентностям. Вестник ТГУ. 2012. Вып. 10 (114). С. 103-112.

26. Кошонько Г. Сутність та структура професійної компетентності педагога. Теорія і практика професійної підготовки фахівців у контексті загальноєвропейських інтеграційних процесів : зб. наук. пр. Житомир : ФОП Левковець, 2016. С. 30-37.

27. Криштанович М.Ф. Зміст і сутність структури професійно-педагогічної компетентності викладача закладу вищої освіти. Інновачійна педагогіка. 2018. Вип. 4 (22). Т. 2. С. 21-24. URL : http://www.innovpedagogy.od.ua/archives/ 2018/4/part 2/4-2 2018.pdf.

28. Леонтьев Д.А. Личностный потенциал: структура и диагностика. М. : Смысл, 2014. 607 с.

29. Липовська К. «Інтелектуальний потенціал» у контексті управління суспільним розвитком: поняття та сутність. Державне управління та місцеве самоврядування. 2017. Вип. 4 (35). С. 21-27. URL : http://www.dridu.dp.ua/vidavnictvo/ 2017/2017 04(35)/5.pdf.

30. Манів С.3. Інтелектуальний потенціал: його суть та складові. Економіка та держава. 2009. № 6. C. 51. URL : www.economy.in.ua.

31. Мирончук Н. Трансформація функціонально-професійної ролі викладача вищої школи в умовах соціокультурних змін. Митець - культура - виміри часу : міжнародні наукові читання (Житомир, 2017) : зб. стат. ; ред.упоряд. І.Є. Копоть. Житомир : Вид. О.О. Євенок, 2017. С. 377-387.

32. Мунтян С.Г. Професійний профіль викладача іноземної мови в європейському освітньому просторі. Сучасні проблеми гуманітаристики: світоглядні пошуки, комунікативні та педагогічні стратегії : матеріали $\vee$ Всеукр. наук.практ. конф. Рівне : РІКУП НАНУ, 2015. С. 264-266.

33. Муромець В.Г. Опис програми розвитку загальних компетентностей здобувачів третього (освітньонаукового) рівня вищої освіти. Вісник Чернігівського національного педагогічного університету імені Т.Г. Шевченка. Серія: Педагогічні науки. 2018. № 45. С. 134-147.

34. Національний класифікатор України «Класифікатор видів економічної діяльності ДК 009:2010», затверджений наказом Державного комітету України з питань технічного регулювання та споживчої політики від 11.10.2010 № 457. URL : https://zakon.rada.gov.ua/rada/show/vd457609-10.

35. Ничкало Н.Г. Розвиток людського капіталу - стратегічне завдання професійної освіти. Педагогічна $i$ психологічна наука в Україні : зб. наук. пр. У 5 т. Т.4 Професійна освіта і освіта дорослих. К. : Педагогічна думка, 2012. C. 27-43.

36. Панок В.Г., Рудь Г.В. Психологія життєвого шляху особистості : моногр. К. : Ніка-Центр. 2006.280 с.

37. Печенюк А. Науково-педагогічний потенціал вищої освіти України: тенденції формування та ефективності використання. Професійна орієнтація та підготовка кадрів. Україна: аспекти праці. 2013. № 4. C. 22-27. URL: http://nbuv.gov.ua/UJRN/Uap 201346.

38. Помиткін Е.О. Психологічні механізми духовного розвитку професіонала: сутність та діагностика. Професійна освіта: педагогіка і психологія: пол.-укр. журн., укр-пол. [щорічник] / за ред. Т. Левовицького, І. Вільш, І.Зязюна, Н. Ничкало. Ченстохова; К., 2008. [Вип.] Х. С. 281-287. URL : http://lib.iitta.gov.ua/6186/1/ - 08 doc.pdf.

39. Про вищу освіту : Закон України від 01.07.2014 № 1556-VII. URL : https://zakon.rada.gov.ua/laws/show/155618 ?find.

40. Про затвердження кваліфікаційних характеристик професій (посад) педагогічних та науково-педагогічних працівників навчальних закладів : наказ Міністерства освіти і науки України від 01.06.2013 № 665. URL: https://zakon.rada.gov.ua/rada/show/v0665729-13\#Text.

41. Про наукову і науково-технічну діяльність : Закон України від 26.11.2015 № 848-VIII. URL: https://zakon.rada.gov.ua/laws/show/848-19\#Text.

42. Про освіту : Закон України від 05.09.2017 № 2145-VIII. URL : https://zakon.rada.gov.ua/laws/show/2145-19.

43. Пустовіт Л.О., Скопненко О.І., Сюта Г.М., Цимбалюк Т.В. Сучасний словник іншомовних слів. К. : Довіра, 2000.

$670 \mathrm{c}$.

44. РегейлоІ.Ю. Фундаментальні цінності Європейського простору вищої освіти (2010-2018рр.): пріоритетні орієнтири діяльності науково-педагогічних працівників. Педагогічний процес: теорія і практика. 2018. № 4 (63). С. 7-17.

45. Результати загальнонаціонального опитування «Перспективи та потреби розвитку університетів України у процесі реформування вищої освіти у контексті європейської інтеграції»; за заг. ред С. Калашнікової. Київ : Інститут вищої освіти НАПН України, 2019. 64 с. URL : https://ul-journal.org/index.php/journal/article/view/105/98.

46. Рябченко В. Розвиток особистісного потенціалу академічного персоналу і здобувачів вищої освіти як інтегрований критерій результативності та ефективності університетського управління. Університети і лідерство. 2019. № 1 (7). C. 65-88. URL : https://core.ac.uk/download/pdf/348932967.pdf.

47. Скиба Ю. Досвід розроблення професійних стандартів науково-педагогічних працівників закладів вищої 
освіти Великої Британії. Освітологічний дискурс. 2018 № 3-4 (22-23). C. 283-298. URL : https://od.kubg.edu.ua/index.php/ journal/article/view/547

48. Скиба Ю.А. SWOT-аналіз як інструмент виявлення науково-педагогічного потенціалу українських університетів. Освітологічний дискурс. 2020. Вип. 3. С. 86-109. URL : https://od.kubg.edu.ua/index.php/ journal/article/view/737.

49. Скиба Ю.А. Професійний профіль і кваліфікаційні рівні науково-педагогічних працівників університетів в умовах інтеграції вищої освіти і науки. Теоретичні основи і технологія професійного розвитку науково-педагогічних працівників університетів в умовах інтеграції вищої освіти і науки : монографія / авт. кол.: О.Г. Ярошенко, О.В. Жабенко, Ю.А. Скиба, Н.О. Дівінська, І.Ю. Регейло, Г.П. Чорнойван ; за ред. О.Г. Ярошенко. К. : Інститут вищої освіти НАПН України, 2019. С. 30-32. URL: $\quad$ https://ihed.org.ua/wp-content/uploads/2020/04/Tehnologiya prof rozvitku pracivn VNZ Monogr IVO-2019236p avtors-kolektiv.pdf.

50. Словник української мови. Академічний тлумачний словник. URL : http://sum.in.ua.

51. Слюсаренко О.М. Розвиток найвищого університетського потенціалу в умовах глобалізації: аналіз світового досвіду : дис. д-ра пед. наук : 13.00.06. Київ, 2015. 435 c. URL: http://umo.edu.ua/images/content/spec rada/ dasertacii/Дисертація фінал Слюсаренко.pdf.

52. Стратегія розвитку вищої освіти в Україні на 2021-2031 роки. К., 2020.71 с. URL: https://mon.gov.ua/storage/app/media/rizne/2020/09/25/rozvitku-vishchoi-osviti-v-ukraini-02-10-2020.pdf.

53. ТарханЛ. Теоретичні і методичні основи формування дидактичної компетентності майбутніх інженерівпедагогів : автореф. дис. ... докт. пед. наук : спец. 13.00.04 «Теорія і методика професійної освіти». К., 2008. 40 с.

54. Угода про асоціацію між Україною, 3 однієї сторони, та Європейським Союзом, Європейським співтовариством з атомної енергії і їхніми державами-членами, з іншої сторони : ратифіковано Законом України від 16.09.2014 № 1678-VII. URL : https://zakon.rada.gov.ua/laws/show/984 011\#Text.

55. Философская энциклопедия / под редакцией Ф.В. Константинова. URL : http://philosophy.niv.ru.

56. Чорнойван Г.П. Досвід вітчизняних закладів вищої освіти щодо створення умов кар'єрного зростання науково-педагогічних працівників. Актуальні питання підготовки майбутнього вчителя хімії: теорія і практика : зб. наук. праць. Вінниця : ТОВ «Нілан-ЛТД», 2018. Вип. 5. С. 55-58.

57. Ярошенко О. Науково-педагогічний потенціал університету як предмет наукового дискурсу. Неперервна професійна освіта: теорія і практика. Серія: Педагогічні науки. 2020. Вип. 2 (63). С. 7-13.

58. Ярошенко О.Г. Дослідницька компетентність науково-педагогічного працівника і їі розвиток в умовах інтеграції вищої освіти і науки. Проблеми освіти : зб. наук. пр. Вінниця : ТОВ «Нілан-лТД». 2018. Вип. 88. Ч. 2. С. 339-347.

59. Blašková M., Blaško R., Jankalová M., Radoslav J. Key Personality Competences of University Teacher: Comparison of Requirements Defined by Teachers and/Versus Defined by Students. Procedia - Social and Behavioral Sciences. February 2014. C. 466-475. URL: https://www.researchgate.net/publication/272703344 Key Personality Competences of University_Teacher_Comparison_of_Requirements_Defined_by_Teachers_andVersus_Defined_by_Students.

60. Blašková M., Blaško R., Matuska E., Rosak-Szyrocka J. Development of Key Competences of University Teachers and Managers. Social and Behavioral Sciences. 2015. C. 187-196. URL: https://www.researchgate.net/publication/ 277949648 Development of Key Competences of University Teachers and Managers.

61. Boyatzis R. The competent manager. New York : Wiley, 2005. 406 p.

62. Bucharest Communiqué "Making the Most of Our Potential: Consolidating the European Higher Education Area», Bucharest, on 26 and 27 April 2012. URL : http://www.ehea.info/Uploads/(1)/Bucharest\%20Communique\%202012(1).pdf.

63. Cano-Hurtado J.J., Carot-Sierra J.M., Fernández-Prada M.A., Fargueta F. An evalution model of the teaching activity of academic staff. URL : https://www.oecd.org/education/imhe/43977296.pdf.

64. Dengerink J., Lunenberg M. and Korthagen F. The Professional Teacher Educator: Six Roles. Beiträge Zur Lehrerinnen- und Lehrerbildung. 2015. № 33 (3). URL : https://www.researchgate.net/publication/295869073.

65. Nair P. A Study on Identifying Teaching Competencies and Factors Affecting Teaching Competencies with Special. A Thesis submitted to Gujarat Technological University for the Award of Doctor of Philosophy in Management. Gujarat Technological University. Ahmedabad. 2017.

66. Paris Communiqué. Paris, May 25th 2018. URL : http://www.ehea.info/media.ehea.info/file/BFUG Meeting/48/8/ BFUG BG SR 614 FinalDraftCommunique 947488.pdf.

67. Rollen- und Kompetenzprofilefuer hochschuldidaktisch rarbeitet von der Arbeitsgruppe Weiterbildung (AGWB) in der Deutschen Gesellschaft für Hochschuldidaktik (dghd). Tobina Brinker, Sabine Brendel, Dorothea Ellinger, Julia Gerber ... Überarbeitete und korrigierte Version. 2018. URL: https://www.dghd.de/wp-content/uploads/2018/02/Rollenund Kompetenzprofile fuer hochschuldidaktisch Taetige final.pdf.

68. Supporting growth and jobs - an agenda for the modernization of Europe's higher education systems. Communication from the European Commission to the European Parliament, the Council, the European Economic and Social Committee and the Committee of the Regions, Brussels, XXX. - COM(2011) 567/2. \{SEC(2011) 1063\}. 16 p.
69. Yerevan
Communiqué :
EHEA
Ministerial
Conference,
2015.

URL : 


\title{
Розвиток дослідників (наукових працівників) в університетах України \\ в умовах євроінтеграції: теоретичні основи
}

\author{
Ганна Чорнойван, \\ кандидат педагогічних наук, \\ старший науковий співробітник, \\ Відділ інтеграції вищої освіти і науки, \\ Інститут вищої освіти НАПН України, \\ https://orcid.org/0000-0001-8935-6000
}

Анотація. У розділі здійснено обґрунтування механізмів реалізації особистісного, творчого і наукового потенціалу дослідників, академічної мобільності; виявлено принципи досконалості, конкурентоспроможності і відкритості наукових досліджень, особистісного цілепокладання і неперервності кар'єрного розвитку; тенденції посилення євроінтеграції вищої освіти і науки, гуманізації вищої освіти, «Відкритої науки».

Інтеграція вітчизняної освіти і науки до Європейського дослідницького простору відкриває перед університетами нові перспективи і горизонти розвитку. Зважаючи на постійний моніторинг Європейський дослідницький простір розширює і оновлює можливості своєї діяльності. Зокрема, оновлена політика Європейського дослідницького простору полягає у збільшенні інвестицій для проведення реформ у науководослідницькій та інноваційній діяльності: підтримка цифровізації; дотримання досконалості досліджень та інновацій для дослідників по всьому ЄС; збільшення процесів комерціалізації результатів в економіку для посилення конкурентоспроможності та лідерства Європи у галузі технологій; вільний обіг знань, дослідників та технологій за рахунок посилення співпраці з країнами ЄС в умовах «Відкритої науки».

Наголошено на необхідності реалізації досконалості дослідження і розробок, затвердження «Положення про дослідницькі університети», активізації університетів до отримання статусу «дослідницьких» та входження і зайняття ключових позицій у світових рейтингах університетів.

Ключові слова: теоретичні основи розвитку дослідника, потенціал, дослідник, науковий працівник, євроінтеграція, інституційні політики, заклади вищої освіти, міжнародні рейтинги. 


\section{Постановка проблеми та ї̈ актуальність}

Актуальність розвитку дослідників в університетах зумовлена підвищенням якості наукової та інноваційної діяльності, розбудовою дослідницького потенціалу закладів вищої освіти в контексті інтеграції до European Higher Education Area ${ }^{1}$ (Європейського простору вищої освіти - ЄПВО) і European Research Area ${ }^{2}$ (Європейського дослідницького простору - ЄДП), участі у міжнародних рамкових програмах (Горизонт-2020), співробітництва між університетами щодо мобільності, впровадження спільних освітніх і дослідницьких програм тощо.

19 листопада 2020 року в Римі (Італія) відбулася конференція Міністрів вищої освіти Європейського nростору вищої освіти «Embrace the Challenge, Creating new Spaces, cancelling Distance» ${ }^{3}$. За результатами зустрічі представників 48 країн ЄПВО (додано країну Сан Марино) досягнуто спільне бачення подальшого співробітництва й ухвалено Final Draft of the Rome Ministerial Communique ${ }^{4}$ що визначає ключові орієнтири глобальної співпраці у сфері вищої освіти до 2030 року. Головні пріоритети на наступні десять років полягають у:

- інклюзивності: рівноправний доступ до вищої освіти, отримання повної підтримки у завершенні навчання й підготовки;

- інноваційності: впровадження нових методів й практик навчання, викладання та оцінювання, що тісно поєднані з дослідженнями;

- взаємозв'язаності: спільні рамки й інструменти продовжать сприяти та активізувати міжнародне співробітництво та реформування, обмін знаннями та мобільність дослідників.

Зазначені пріоритети посилюють роль розвитку потенціалу університетів і дослідників. На конференції порушувалися ключові питання щодо академічної свободи та необхідності інституційної автономії з тісними зв'язками із стейкхолдерами. Університети повинні користуватися достатнім простором та гнучкістю у своїх стратегічних рішеннях, спираючись на тісні консультації з представниками ринку праці, здобувачами вищої освіти та відповідними громадами.

Євроінтеграційні процеси України зумовлюють відповідальність і розділення головних пріоритетів ЄПВО. Більш того, варто переглянути вітчизняні інституційні політики щодо інклюзивності та різноманітності. Такий підхід дозволить вищій освіті забезпечити постійно зростаюче різноманіття здобувачів різного віку, соціальних груп, досвіду та рівня кваліфікації5 , а також реалізувати гнучкі освітні траєкторії в рамках нового бачення концепції навчання протягом життя, яке враховує різноманітні освітні потреби для професійного й особистісного розвитку.

Пріоритети розвитку і реформування вітчизняної вищої освіти закладені в проєкті «Стратегії розвитку вищої освіти в Україні на 2021-2031 роки» ${ }^{6}$ (далі - Стратегія). Розділ Стратегії «Візія, місія і принципи побудови системи вищої освіти України» визначає необхідність розбудови потужних дослідницьких університетів, які здійснюватимуть освітній процес за багатьма галузями знань, забезпечуватимуть поглиблену теоретичну і практичну підготовку, здійснюватимуть фундаментальні та прикладні дослідження у пріоритетних і перспективних напрямах розвитку науки і техніки.

Статус дослідницького університету прописано у Законі України «Про вищу освіту» ${ }^{7}$ (ст. 30). Він надається закладу вищої освіти у разі забезпечення розвитку держави в певних галузях знань за моделлю поєднання освіти, науки та інновацій, сприяння ії інтеграції у світовий освітньо-науковий простір, наявності визнаних наукових здобутків, для стимулювання наукової, науково-технічної та інноваційної діяльності і проведення міждисциплінарних досліджень строком на 5 років.

\footnotetext{
${ }^{1}$ European Higher Education Area. URL : https://ec.europa.eu/education/policies/higher-education/bologna-process-and-european-highereducation-area en.

2 European Research Area. URL : https://ec.europa.eu/info/research-and-innovation/strategy/era en.

${ }^{3}$ Конференція Міністрів вищої освіти Європейського простору вищої освіти «Embrace the challenge, creating new spases, cancelling distance» (19.11.2020p. Рим, Італія). URL : https://ehea2020rome.it/pages/ehea2020.

${ }^{4}$ Final Draft of the Rome Ministerial Communique. URL : https://mon.gov.ua/storage/app/media/rizne/2020/11/19/BFUG_compressed.pdf.

5 Entering a decade of flexibility and diversity: a new momentum for professional higher education / EURASHE's statement for the European Higher Education Area ministers' conference in Rome 2020. URL: https://ehea2020rome.it/storage/uploads/22113e75-cf83-4009-814eada67e84db5e/EURASHE Statement EHEA Ministerial Conference Rome2020.pdf.
}

${ }^{6}$ Стратегія розвитку вищої освіти в

https://mon.gov.ua/storage/app/media/rizne/2020/09/25/rozvitku-vishchoi-osviti-v-ukraini-02-10-2020.pdf.

7 Про вищу освіту : Закон України від 01.07.2014 № 1556-VII. URL : https://zakon.rada.gov.ua/laws/show/1556-18\#Text. 
Умовами отримання статусу дослідницького університету $\epsilon^{8}$ :

1) «наявність інституційної акредитації;

2) присутність у міжнародних рейтингах закладів вищої освіти, перелік яких визначається Національним агентством із забезпечення якості вищої освіти;

3) одержання за результатами проходження державної атестації в частині провадження ним наукової (науково-технічної) діяльності впродовж не менше трьох із попередніх п'яти років найвищої позиції не менш як за одним науковим напрямом або однієї з трьох найвищих позицій не менш як за трьома науковими напрямами».

Наразі «Положення про дослідницький університет» (Постанова Кабінету Міністрів України від 17.02.2010 № 163), відповідно якого надавався статус дослідницького університету, втратило чинність ${ }^{9}$. У 2018 році Міністерством освіти і науки України подано проєкт «Положення про дослідницький університет». Це Положення "осучаснило» і підвищило вимоги до отримання закладами вищої освіти статусу дослідницьких. Критерії діяльності університетів містять інформацію щодо ${ }^{10}$ : успішного проходження державної атестації закладом вищої освіти в частині провадження ним наукової (науково-технічної) діяльності; дотримання академічної доброчесності; запровадження для вступної кампанії прохідного балу не нижче 120; місця університету у національних і міжнародних рейтингах; кількості наукових публікацій у періодичних виданнях, що включені до наукометричних баз Scopus або Web of Science Core Collection; рівня наукової активності і стажувань наукових та науково-педагогічних працівників; кількості аспірантів, докторантів і молодих вчених тощо.

Зазначимо, що в більшій мірі критерії діяльності університетів в проєкті «Положення про дослідницький університет» відповідають окремим показникам оцінювання дослідницької діяльності міжнародних рейтингів Times Higher Education (THE) World University Rankings ${ }^{11}$ та Academic Ranking of World Universities $(A R W U)^{12}$. Посилення вимог до отримання статусу дослідницьких університетів, оновлення процедури отримання статусу, збільшення терміну до 7 років, відкритість процесу та інші нововведення сприятимуть розвитку потенціалу університетів і міжнародного визнання.

Приємно зазначити, що у 2020 р. до рейтингів найкращих університетів світу Times Higher Education (THE) World University Rankings ${ }^{13}$ та QS World University Rankings ${ }^{14}$ включено сім закладів вищої освіти України: Харківський національний університет ім. В.Н. Каразіна; Київський національний університет імені Тараса Шевченка, Національний технічний університет «Харківський політехнічний інститут», Національний технічний університет «Київський політехнічний інститут імені Ігоря Сікорського», Сумський державний університет, Національний університет «Львівська політехніка», Львівський національний університет імені Івана Франка.

Включення вітчизняних університетів до міжнародних рейтингів підвищує імідж України в сфері освіти і науки. Поряд з цим, є ще багато викликів, на які варто звертати увагу. Одним з викликів $є$ розбудова потужного кадрового потенціалу університетів і зупинення відтоку наукових та науково-педагогічних працівників. Відповідно інституційна політика має, в першу чергу, спиратися на набір дослідників, розвиток професійних компетентностей, сприяння кар'єрного і особистісного потенціалу дослідників, створення сприятливих умов для залучення молоді.

\footnotetext{
8 Про вищу освіту : Закон України від 01.07.2014 № 1556-VII. п. 4, ст. 30. URL : https://zakon.rada.gov.ua/laws/show/1556-18\#Text.

9 Про внесення змін та визнання такими, що втратили чинність, деяких актів Кабінету Міністрів України : постанова Кабінету Міністрів України від 05.11.2014 № 597. URL : https://zakon.rada.gov.ua/laws/show/597-2014-n\#Text.

10 Положення про дослідницький університет : проєкт / Міністерство освіти і науки України. URL : https://mon.gov.ua/ua/news/monproponuye-dlya-gromadskogo-obgovorennya-proekt-polozhennya-pro-doslidnickij-universitet.

${ }^{11}$ The World University Rankings 2020: methodology. URL: https://www.timeshighereducation.com/world-university-rankings/worlduniversity-rankings-2020-methodology.

12 Shanghai Ranking Academic Excellence Survey 2020 Methodology. URL: http://www.shanghairanking.com/subject-survey/surveymethodology-2020.html.

13 Times Higher Education (THE) World University Rankings (Ukraine, 2020). URL : https://www.timeshighereducation.com/world-universityrankings/2020/world-ranking\#!/page/O/length/25/locations/UA/sort by/rank/sort order/asc/cols/stats.

${ }^{14}$ QS World University Rankings (Ukraine, 2020). URL : https://www.topuniversities.com/university-rankings/world-university-rankings/2021.
} 


\section{Сучасний стан розвитку дослідників (наукових працівників) університетів}

Розглянемо понятійно-категоріальний апарат проблеми дослідження. У Законі України «Про наукову $і$ науково-технічну діяльність» ${ }^{15}$ зазначено, що науковий працівник, це вчений, який має вищу освіту не нижче другого (магістерського) рівня, відповідно до трудового договору (контракту) професійно провадить наукову, науково-технічну, науково-організаційну, науково-педагогічну діяльність та має відповідну кваліфікацію незалежно від наявності наукового ступеня або вченого звання, що підтверджено результатами атестації у випадках, визначених законодавством.

Термін «дослідник» асоціюється з поняттям «науковий працівник», позначає фахівців, що здійснюють науково-дослідницьку діяльність. У «European Charter for Researchers The Code of Conduct for the Recruitment of Researchers» ${ }^{16}$ зазначено, що дослідники - це «професіонали, які працюють у сфері розроблення або створення нового знання, продуктів, процесів, методів і систем, а також у сфері управління такими проєктами». Підкреслено, що в цю категорію входять фахівці, що задіяні у науково-дослідницькій та дослідно-конструкторській діяльності або діяльності у сфері фундаментальних, стратегічних, прикладних досліджень, включаючи інновації, консультативно-дорадчу діяльність, наукове керівництво та викладання, управління знаннями та права інтелектуальної власності тощо.

У "Cтатистичному щорічнику України за 2018 рік» ${ }^{17}$ дослідниками визначено категорію наукових та інженерно-технічних працівників, це особи які професійно займаються науковими дослідженнями та розробками, беруть безпосередню участь у створенні нових знань, продуктів, процесів, методів та систем. До цієї категорії відноситься адміністративно-управлінський персонал, який здійснює безпосереднє керівництво дослідницьким процесом. Також зазначено кваліфікаційні вимоги до дослідників, як правило, вони повинні мати вищу освіту другого, третього або наукового рівня.

Зазначені вище поняття «наукових працівників» та «дослідників» характеризують одну й ту ж категорію фахівців, що здійснюють наукові дослідження та іншу діяльність, результатом якої є продукування нового знання, розробок і відкриттів, тому далі в дослідженні використовуватимемо ці категорії як синоніми.

Статистичні дані свідчать, що всього кількість працівників, що задіяні у виконанні наукових досліджень і розробок у період 2010-2019 рр. зменшилась на 33,2 \% (2010 р. - 56800 осіб; 2019 - 37921 осіб) ${ }^{18}$, з них доктори наук на 17,1 \%, кандидати наук на 28,5 \%. Зокрема по категоріях: кількість дослідників зменшилася на 37,2 \% (40 636 осіб - 2010 р., 25499 осіб - 2019 р.), що вказує на втрату дослідницького потенціалу університетів. Більше ніж на половину скоротилася кількість техніків (57,2). Найменше скорочення відбулося допоміжного персоналу, що становить 5,2 \%.

Негативним фактором є зменшується фінансування науки. У розділі «Основні тенденції та проблеми розвитку системи вищої освіти в Україні» Стратегії зазначено, що ${ }^{19}$ : «заробітна плата науково-педагогічного персоналу ЗВО в Україні набагато нижче, ніж у провідних країнах. У 2017/2018 н.р. річна заробітна плата найбільш кваліфікованого персоналу - професорів - в Україні склала 5,7 тис. дол. США, у Великій Британії 116,7 тис. дол., у Німеччині - 99,5 тис. дол.; викладачів (лекторів) - 4,7 тис. дол. в Україні, 54,2 тис. дол. - у Великій Британії, 58,8 тис. дол. - у Німеччині».

Найбільш критичним, на наш погляд, є відтік досвідчених наукових працівників закордон або в інші сектори економіки, що є більш перспективними і оплачуваними. Натомість, українська молодь не поспішає присвятити себе науці ${ }^{20}$ : «з 2010 р. до 2019 р. кількість аспірантів в Україні скоротилась на 19,5 \% (23 тис.

15 Про наукову і науково-технічну діяльність : Закон України від 26.12.2015 № 848-VIII. URL : https://zakon.rada.gov.ua/laws/show/84819\#Text.

${ }_{16}$ The European Charter for Researchers The Code of Conduct for the Recruitment of Researchers. C. 22. URL : http://h2020.com.ua/wpcontent/uploads/2015/11/Book.pdf.

${ }_{17}$ Статистичний щорічник України за 2018 рік / Державна служба статистики України. C. 440. URL: http://www.ukrstat.gov.ua/druk/publicat/kat_u/2019/zb/11/zb_yearbook_2018.pdf.

18 Кількість працівників, задіяних у виконанні наукових досліджень і розробок, за категоріями персоналу (2010-2018рр.) / Головне управління статистики у м. Києві. (Примітка: Дані за 2010-2015 роки включають постійних та тимчасових працівників (сумісників та осіб, які працюють за договорами цивільно-правового характеру, включаючи науково-педагогічних працівників). Починаючи з 2016 року дані наведено без урахування науково-педагогічних працівників, які не виконували наукові дослідження і розробки). URL: http://www.kiev.ukrstat.gov.ua/p.php3?c=3257\&lang=1.

${ }^{19}$ Стратегія розвитку вищої освіти в Україні на 2021-2031 роки. К., 2020.71 с. C. $19 . \quad$ URL: https://mon.gov.ua/storage/app/media/rizne/2020/09/25/rozvitku-vishchoi-osviti-v-ukraini-02-10-2020.pdf.

${ }^{20}$ Стратегія розвитку вищої освіти в Україні на 2021-2031 роки. К., $2020 . \quad 71$ с. C. 20-21. URL: https://mon.gov.ua/storage/app/media/rizne/2020/09/25/rozvitku-vishchoi-osviti-v-ukraini-02-10-2020.pdf. 
осіб), кількість зарахованих у 2019 р. зменшилася порівняно з 2010 р. на 22,8 \% (6 780 осіб). Загальна кількість докторантів зменшилася на 24,2% (937 осіб), зарахованих на навчання - на 9,7% (435 осіб)».

Зважаючи на вищезазначене, стан розвитку науки в Україні потребує чіткої і системної політики щодо підвищення престижності наукової роботи, зокрема професії наукового працівника; створення умов для реалізації особистісного, творчого і наукового потенціалу наукових працівників; зростання показників фінансування наукових досліджень і підвищення заробітної плати; залучення молоді до науки шляхом соціальних гарантій і підтримки з боку держави; посилення зв'язку вищої освіти, науки і бізнесу тощо. 


\section{Аналіз наукових публікацій щодо розвитку потенціалу дослідників}

Розвиток дослідника складається з системи взаємопов'язаних елементів, зокрема розкриття особистісного, творчого і наукового потенціалу. В Академічному тлумачному словнику ${ }^{21}$ поняття потенціал означає «сукупність усіх наявних засобів, можливостей, продуктивних сил, що можуть бути використані в будь-якій галузі, ділянці, сфері».

Ф. Подшивайловою, Л. Подшивайловою у статті «Мотиваційне забезпечення розвитку творчого nотенціалу особистості» 22 розкрито поняття творчого потенціалу особистості. Автори підкреслюють значимість у професійній діяльності творчості, що є важливою засадою росту професіоналізму людини, творчої самореалізації з точки зору досягнення суспільної корисності результатів творчості. Творчість заради творчості може бути суспільно корисною лише при дотриманні двох основних вимог - вона повинна бути гуманістично спрямованою та «творець» повинен бути дуже талановитим (аж до геніальності)». Автори відзначають, що зазвичай потенціал можна розкрити лише у професійній або іншій сфері діяльності, що $є$ корисною суспільству.

Виокремлено компоненти творчого потенціалу В. Марущак у праці «Творчий потенціал особистості як одна з рушійних сил у розвитку та формуванні вчителя майбутнього» ${ }^{23}$ :

- ініціативність (бажання першим робити крок у будь-якій справі, що пов'язана з навчальнопізнавальною або професійно-пізнавальною діяльністю);

- здатність рухатися вперед (після звершення власних планів у сфері самореалізації, уміння поставити перед собою нову ціль);

- впевненість у собі (безпроблемне відкидання всіляких сумнівів і повна гармонія власних можливостей та її реалізація);

- прагнення по максимуму використовувати можливості, що з'явилися (бачити проблему з різних сторін та вміти використовувати набуті знання на практиці);

- наполегливість (доводити почату справу до кінця й отримувати максимальній результат).

Важливий акцент на розвиток потенціалу молоді зробили О. Коханова, О. Столярчук у праці «Особистісний потенціал як засіб самореалізації сучасної молоді» 24 . Автори провели дослідження, в ході якого було виявлено залежність особистісного потенціалу від здібностей і інтелекту, а також характеру, комунікативних вмінь та афективно-вольової сфери. Також під час дослідження встановлено зв'язок між розвитком особистісного потенціалу і досягненням життєвого успіху.

Є. Завгородня у праці «До проблеми розвитку творчого потенціалу особистості» ${ }^{25}$ порушує питання пошуку ефективних методів навчання та розвитку особистості дорослої людини. Автор описує творчого фахівця як особистість, яка характеризується високим рівнем креативності (креативні риси особистості й додатково сформовані мотиви, особистісні якості, здібності, які сприяють успішній творчій діяльності) та відповідним рівнем фахових знань, які за сприятливих умов забезпечують його ефективну діяльність щодо розвитку потенційних творчих можливостей.

К. Шелестун у праці "Умови розвитку й реалізації наукового потенціалу» ${ }^{26}$ визначає наукову активність передумовою реалізації наукового потенціалу. Авторка під науковою активністю розуміє «цілеспрямовані дії ученого на розвиток або саморозвиток (самореалізацію, самоактуалізацію) в науці та науково-дослідницькій діяльності». Провівши емпіричні дослідження, дослідниця дійшла висновку, що в основі наукової активності вчених природничих спеціальностей лежать ціннісно-раціональні дії, такі як: орієнтація на саморозвиток у науці, творча діяльність та реалізація здобутих знань на практиці. Тоді як в основі наукової активності вчених соціо-гуманітарних спеціальностей, лежать раціональні дії, такі як: отримання престижу, отримання матеріальної винагороди та успішна наукова кар'єра.

\footnotetext{
${ }^{21}$ Академічний тлумачний словник. URL : http://sum.in.ua/s/potencial.

22 Подшивайлова Ф., Подшивайлова Л. Мотиваційне забезпечення розвитку творчого потенціалу особистості. URL : http://oldconf.neasmo.org.ua/node/2105.

${ }^{23}$ Марущак В. Творчий потенціал особистості як одна з рушійних сил у розвитку та формуванні вчителя майбутнього. Педагогічні науки: теорія, історія, інноваційні технології. 2016. № 5 (59). С. 327.

24 Коханова О.П., Столярчук О.А. Особистісний потенціал як засіб самореалізації сучасної молоді. URL: http://appsychology.org.ua/data/irn/v6/i15/22.pdf.

25 Завгородня Є.Є. До проблеми розвитку творчого потенціалу особистості. Неперервна професійна освіта: теорія і практика. 2015. Вип. 4 (45). С. 26.

${ }^{26}$ Шелестун К.Ю. Умови розвитку й реалізації наукового потенціалу. Наукові праці. Соціологія. 2014. Вип. 222. Т. 234. С. 75-76.
} 
У цілому поділяємо позицію автора в тому, що розвиток наукового потенціалу має забезпечуватися, в першу чергу, на державному рівні, а потім вже на інституційному і особистому. Серед ініціатив має бути розроблення і реалізація державних програм, посилення фінансування матеріально-технічної бази, сприяння престижу професії науковця, забезпечення доступністю інформаційно-комунікаційними технологіями і ресурсами, відкритими базами даних бібліотечних і архівних фондів.

У праці 3. Юрченко "Науковий потенціал особистості: психологічні чинники актуалізації» ${ }^{27}$ розглядає науковий потенціал через призму підвищення рефлексивної культури мислення. Автор зазначає, що ${ }^{28}:$ механізмом, що запускає розвиток наукового потенціалу особистості, $€$ зв'язок самоактуалізації із задоволеністю дослідницькою діяльністю. Задоволеність розглядається як ступінь співвіднесення людиною своїх актуальних і потенційних можливостей у сфері науки, актуального рівня розвитку із вимогами, що висуваються до дослідника.

Співвідношення розвитку наукового потенціалу і задоволеності від здійснення діяльності також розглядає Г. Скиба у праці «Сучасний стан науково-технічного потенціалу України: вітчизняні реалії та зарубіжний досвід» ${ }^{29}$. Дослідниця порушує важливе питання щодо залучення аспірантів і докторантів до наукових досліджень університетів для ефективності досліджень і сприяння успішному захисту дисертацій. У праці наголошено на тому, що ${ }^{30}:$ «менше третини всіх науковців безпосередньо працює в науковій сфері. Гострою проблемою $€$ наростаючий розрив міждисциплінарних зв'язків і циклу «Фундаментальні дослідження - розробки - комерціалізація знань у виробництві». Важливо відмітити, що ці проблеми актуалізують необхідність удосконалення кадрового потенціалу наукового сектору університетів, особливо для молодих науковців, а також налагодження міждисциплінарних зв'язків.

У праці C. Alves "Research methodology: How to maximize your research potential» ${ }^{31}$ наводить практичні рекомендації розвитку потенціалу науковців у сфері наукової діяльності з медицини. Дослідниця акцентує увагу на ролі наставництва для молодих вчених; командній роботі та співпраці; розвитку навичок колективної роботи, комунікації в мережах, вміння вести переговори та здійснювати пошук фінансів тощо.

У праці Ph. Mirowski R. Van Horn "The Contract Research Organization and the Commercialization of Scientific Research» ${ }^{32}$ дослідили процес комерціалізації наукових досліджень та його вплив на розвиток дослідницького потенціалу університету. Особливий акцент зроблено на професійній діяльності у біофармацевтичному секторі наукових досліджень та наслідків сучасного режиму комерціалізованої науки для майбутнього проведення наукових досліджень. Автори наголошують на важливості співпраці університетів і бізнесу для впровадження результатів наукових досліджень, здійснення розробок відповідно потреб і запитів ринку праці, сприяння комерціалізації наукових здобутків задля фінансової автономії університетів.

Отже, аналіз праць свідчить про актуальність розвитку потенціалу дослідників в контексті євроінтеграційних викликів. Дослідники зазначають, що розвиток потенціалу дослідників відбувається через реалізацію творчої, особистісної і наукової складових потенціалу. Задоволеність професійною діяльністю і створення умов для реалізації потенціалу у сукупності визначають успішний кар'єрний розвиток дослідника. В цьому аспекті спостерігається посилена мотивація до дослідницької діяльності, сприяння досконалості і якості досліджень, зростання продуктивності праці і ефективного використання (комерціалізації) результатів наукових досліджень. Звідси слідує, що варто свідомо підходити до вибору професійної діяльності відповідно власних інтересів, можливостей і кар'єрних цінностей.

\footnotetext{
27 Юрченко 3.В. Науковий потенціал особистості: психологічні чинники актуалізації. Вісник Чернігівського національного педагогічного університету. Сер.: Педагогічні науки. 2014. Вип. 115. С. 276-279.

28 Юрченко 3.В. Науковий потенціал особистості: психологічні чинники актуалізації. Вісник Чернігівського національного педагогічного університету. Сер.: Педагогічні науки. 2014. Вип. 115. С. 277.

${ }^{29}$ Скиба Г.В. Сучасний стан науково-технічного потенціалу України: вітчизняні реалії та зарубіжний досвід. Вісник Хмельницького національного університету. 2016. № 6. URL : http://elar.khnu.km.ua/jspui/bitstream/123456789/5357/1/Скиба.pdf.

${ }_{0}$ Скиба Г.В. Сучасний стан науково-технічного потенціалу України: вітчизняні реалії та зарубіжний досвід. Вісник Хмельницького національного університету. 2016. № 6. С. 212. URL : http://elar.khnu.km.ua/jspui/bitstream/123456789/5357/1/Скиба.pdf.

${ }^{31}$ Alves C. Research methodology: How to maximize your research potential. EFORT Open Rev. 2018. V. 3(5). PP. 184-191. URL: https://www.researchgate.net/publication/325274297 Research methodology How to maximize your research potential.

32 Mirowski Ph, Van Horn R. The Contract Research Organization and the Commercialization of Scientific Research. Social Studies of Science. 2005. V. 35 Issue 4. P. 503-548.
} 


\section{Теоретичні основи розвитку наукових працівників в університетах України в контексті євроінтеграції}

Сьогодні на порядку денному Європейської Комісії стоїть питання оновлення Європейського дослідницького простору (далі - ЄДП). Основними цінностями, на яких базується ЄДП є досконалість, конкурентоспроможність, відкритість та розвиток талантів.

Основні пріоритети оновленого ЄДП ${ }^{33}$ :

- посилення мобільності дослідників та відкритий потік знань;

- стимулювання збільшення та розширення сфер інвестування у дослідження та інновації;

- сприяння гендерній рівності та різноманітності в науці;

- посилення співпраці між університетами, бізнесом та іншими учасниками досліджень та інновацій.

Ініціативи оновлення ЄДП спрямовані на покращення дослідницького та інноваційного ландшафту Європи, швидкого переходу ЄС до кліматичної нейтральності та цифрового лідерства, відновлення від соціальних та економічних наслідків світової пандемії COVID-19, готовності до майбутніх криз. Визначено чотири стратегічні цілі діяльності ЄДП ${ }^{34}$ :

- надавати пріоритет інвестиціям та реформам у науково-дослідницькій та інноваційній діяльності, щоб підтримати цифровий та зелений перехід та відновлення Європи;

- покращити доступ до досконалості досліджень та інновацій для дослідників по всьому ЄС;

- комерціалізація результатів в економіку, забезпечення впровадження ринком продукції, що $\epsilon$ результатом науково-дослідницької діяльності для посилення конкурентоспроможності та лідерства Європи у галузі технологій;

- домогтися прогресу у вільному обігу знань, дослідників та технологій за рахунок посилення співпраці з країнами ЄС.

Водночас, головним пріоритетом ЄДП Є створення передумов реалізації потенціалу і професійного розвитку дослідників через платформу Vitae ${ }^{35}$. На сайті платформи представлено профіль досконалого дослідника Researcher Development Framework ${ }^{36}$ (далі - Рамка). Рамка структурована в домени, субдомени та дескриптори, що характеризують відповідну область. Всього Рамка охоплює чотири області:

- Knowledge and intellectual abilities (знання та інтелектуальні здібності);

- Personal effectiveness (персональна ефективність);

- Research governance and organisation (врядування і організація досліджень);

- Engagement, influence and impact (залучення, вплив та діяльність).

Вартий для уваги дослідників домен Research governance and organization, який характеризує необхідність формування компетентностей у відповідності:

- професійної поведінки;

- управління дослідженнями;

- фінансування та ресурсів.

У загальному і на рекомендаційній основі Рамка може використовуватися для ${ }^{37}$ :

- дослідження сильних сторін та напрямки подальшого розвитку;

- пошуку рекомендацій щодо формальних і неформальні можливості для розвитку;

- створення умов і можливостей дослідникам брати участь у їхньому особистому, професійному та кар'єрному розвитку;

- інформування про конструктивні дискусії щодо кар'єрних можливостей як в академічних колах, так і за їх межами, що відповідають індивідуальним потребам дослідника;

- планування регулярних оглядових зустрічей або оцінки нових навичок та напрямків розвитку.

Водночас на сайті Vitae, представлено допоміжні інструменти для планування професійного розвитку

\footnotetext{
${ }^{33}$ Commission's plan for a new European Research Area based on excellence. URL: https://ec.europa.eu/info/research-andinnovation/strategy/era_en.

34 Four strategic objectives European Research Area. URL : https://ec.europa.eu/info/research-and-innovation/strategy/era en.

35 Vitae. Realising the potential of researchers, globally. URL : https://www.vitae.ac.uk/

${ }^{36}$ Researcher Development Framework. URL : https://www.vitae.ac.uk/vitae-publications/rdf-related/researcher-development-frameworkrdf-vitae.pdf/view.

37 Enhancing the professional development of researchers. URL : https://www.vitae.ac.uk/researchers-professional-development/about-thevitae-researcher-development-framework/managers-supervisors-and-the-vitae-researcher-development-framework.
} 
дослідників, зокрема онлайн додаток RDF Planner ${ }^{38}$, онлайн курс «Professional Development Planning For Researchers online course» тощо.

Застосування онлайн ресурсів є гарною практикою розвитку дослідників, особливо зважаючи на проблеми, що пов'язані зі світовою пандемією COVID-19.

Підходи, що закладені у Researcher Development Framework до формування досконалого профілю дослідника, сприяють самовдосконаленню і розвитку особистості дослідника на всіх етапах кар'єрного розвитку.

Викликом і новою можливістю розвитку дослідників університетів України є ініціатива ЄС щодо розширення представництва в ЄДП, долучення до Відкритої хмари європейської науки (European Open Science Cloud, EOSC) ${ }^{39}$ у рамках нової програми «Горизонт Європа». А. Завгородній у праці «Європейська хмара відкритої науки як глобальний інструмент наукових досліджень» зазначає, що відкриття доступу до даних у рамках «Відкритої науки» сприятиме підвищенню якості досліджень, розвитку міждисциплінарних досліджень, створення проривних інновацій, зменшить дублювання досліджень і наукових шахрайств, недоброчесності. Дослідник підкреслює важливість для української науки посилення інтеграції до ЄДП у контексті різноманітних ініціатив і програм. Звісно, що для цього потрібно на національному рівні створювати передумови створення власної інформаційної інфраструктури, готувати фахівців для підтримки і наповнення даними хмар, достатнє фінансування і законодавча база.

Варто зазначити, що провідною тенденцією сучасності є гуманізація освіти ${ }^{40}$. Гуманоцентрична переорієнтація вітчизняної освіти під впливом світових та європейських вимірів передбачає формування фахівця, рівень підготовки якого гармонійно поєднує ключові компетентності, розвиток особистості відповідно до духовних цінностей національної та загальнолюдської культури. Щодо гуманізації освіти цей феномен трактується у двох аспектах: з одного боку, це збільшення кількості та поглиблене вивчення предметів гуманітарного циклу, з іншого - підготовка особистості до вільного, творчого і щасливого життя засобами гуманістичної освіти, пристосування до вимог суспільства та віднайдення свого «я» у ньому 41.

Вважаємо, що для розвитку дослідників визначальним $є$ два аспекти гуманізації освіти, що готує професіонала з набутими компетентностями і цінностями.

У праці У. Парпан «Провідні принципи розвитку сучасної вищої освіти України в контексті євроінтеграції» 42 представлено провідні принципи розвитку сучасної вищої освіти України в контексті євроінтеграції, а саме ${ }^{43}$ : демократизації і варіативності вищої освіти; відповідності вищої освіти світовим стандартам; добровільності та діалогічності; гармонійної організації освітнього середовища; стимулювання студентів до діяльності із самооцінювання, рефлексії, філософствування, пізнання самого себе; єдності наукового і освітнього процесів, управлінської діяльності та їх спрямованості на економічний, соціальний і духовний розвиток суспільства; оптимального поєднання державного регулювання і самоврядування; формування інноваційних проектів за пріоритетними напрямками досліджень; підтримкою провідних науковців, наукових колективів, наукових і науково-педагогічних шкіл, розвиток науково-технічної творчості молоді; підтримки підприємницької діяльності в науковій сфері; інтеграції науки і освіти в міжнародне співтовариство; формування мережевих структур при організації інноваційної і наукової діяльності.

Серед представлених принципів, найбільш актуальними саме в аспекті досліджуваної проблеми $€$ принципи розвитку людського потенціалу університетів, зокрема молодих дослідників і викладачів.

Ретроспективний аналіз діяльності викладачів університетів у контексті культури наукової праці, наставництва, ідей професійного розвитку, саморозвитку і самореалізації дослідника здійснили О. Семеног, М. Вовк у праці «Академічна культура дослідника в освітньо-культурному просторі університету» ${ }^{44}$

\footnotetext{
${ }^{38}$ Researcher Development Framework Planner. URL: https://www.vitae.ac.uk/researchers-professional-development/about-the-vitaeresearcher-development-framework-planner.

39 Загородній A. Європейська хмара відкритої науки як глобальний інструмент наукових досліджень. Газета «Світ». URL : http://www.nas.gov.ua/EN/Messages/Pages/View.aspx?MessagelD=6661.

40 Мартиненко С. Європейський простір вищої освіти: тенденції розвитку та пріоритети. Педагогічні витоки освітології. Ч. VІ. С. 165.

${ }^{41}$ Вовк О.Р. Провідні тенденції гуманізації освіти: теоретичний аналіз. Наукові записки НДУ ім. М. Гоголя. Психолого-педагогічні науки. 2014. № 1. С. 30-34.

42 Парпан У.М. Провідні принципи розвитку сучасної вищої освіти України в контексті євроінтеграції. LEX PORTUS. 2018. № 1 (9). URL : https://core.ac.uk/download/pdf/156902884.pdf.

43 Парпан У.М. Провідні принципи розвитку сучасної вищої освіти України в контексті євроінтеграції. LEX PORTUS. 2018. № 1 (9). URL : https://core.ac.uk/download/pdf/156902884.pdf.

${ }^{44}$ Семеног О., Вовк М. Академічна культура дослідника в освітньо-культурному просторі університету : монографія. Суми : СумДПу імені А.С. Макаренка, 2016. 284 с.
} 
Автори виділяють декілька принципів:

- поєднання різних методів, засобів та форм навчання;

- особистісного цілепокладання.

Застосування комплексу методів і засобів творчо-пошукового, дослідницького, репродуктивного типу стимулює дослідників до творчої активності, самостійності, формування дослідницької культури. Поряд 3 цим, важливо співвідносити прагнення дослідників відповідно їхнім реальним можливостям, індивідуальним здібностям та інтересам. Формування академічної культури сприяє як особистісному, так і професійному розвитку дослідника ${ }^{45}$.

У праці Г. Чорнойван «Теоретичні основи і технології кар'єрного розвитку науково-педагогічних працівників у контексті інтеграції викладацької і дослідницької діяльності» ${ }^{46}$ обґрунтувано принцип неперервності, який характеризується пошуком нових підходів і ідеології у сфері наукових досліджень. Професійний неперервний розвиток дослідника надає можливість навчання впродовж життя; підвищення кваліфікації; вибору або зміни траєкторії руху, сфери дослідження.

Варто відзначити, що посилити розвиток дослідника можна шляхом реалізації механізму академічної мобільності. У праці «Міжнародна академічна мобільність в Україні: проблеми та перспектив» 47 Ю. Грищук наголошує на необхідності на державному рівні здійснювати регулювання процесу академічної мобільності шляхом належного і достатнього фінансування, сприяння участі дослідників у програмах ЄС. Дослідниця рекомендує реалізувати систему академічної мобільності. Відповідно, що такі ініціативи потребують удосконалення нормативно-правової і економічної бази. Варто завчасно передбачати в бюджеті окремі статті для фінансування академічної мобільності та обмінів.

На пріоритетності розвитку наукових досліджень, врахування загальних тенденцій розвитку систем вищої освіти у контексті глобалізаційних та євроінтеграційних процесів наголошує О.Дубасенюк у праці «Розвиток вищої освіти: тенденції та перспективи» ${ }^{48}$. Дослідниця виділяє основні тенденції, викликані інтеграційними процесами і реформуванням зарубіжних систем вищої освіти, насамперед ${ }^{49}$ :

- формування навичок самостійного пошуку перспективних напрямів методології досліджень і відповідних розробок (пріоритетність промислово-і бізнес спрямованість наукових досліджень, патентування розробок, впровадження результатів наукових досліджень у виробництво);

- фундаментальна підготовка загальнотеоретичними і гуманітарними дисциплінами для універсалізації фахівця, здатного здійснювати стратегічні зміни на базі науково-дослідної і конструкторськопроектної діяльності,

- упровадження принципів безперервної освіти (інтеграція формальної, неформальної та інформальної складових безперервного освітнього процесу).

Наголошено, що вище зазначені тенденції розвитку вищої освіти тісно пов'язані з наукою, зокрема акцентовано увагу на інтеграції вищої освіти і науки в контексті сучасних викликів розвитку економіки, суспільства і дослідників зокрема. Посилюється роль фундаментальної підготовки фахівців, які здатні адаптуватися до швидких темпів розвитку технологічних процесів високорозвинених держав, Іт сфери та інформаційно-комунікаційних технологій, викликів кризових станів тощо.

\footnotetext{
${ }^{45}$ Семеног О., Вовк М. Академічна культура дослідника в освітньо-культурному просторі університету : монографія. Суми : СумдпУ імені А.С. Макаренка, 2016. С. 210-211.

46 Чорнойван Г. Теоретичні основи і технології кар'єрного розвитку науково-педагогічних працівників у контексті інтеграції викладацької і дослідницької діяльності. Теоретичні основи і технологія професійного розвитку науково-педагогічних працівників університетів в умовах інтеграції вищої освіти і науки : монографія / авт. кол. К. : Інститут вищої освіти НAПН України, 2019. C. 84-109. URL: https://ihed.org.ua/wp-content/uploads/2020/04/Tehnologiya_prof_rozvitku_pracivn_VNZ_Monogr_IVO-2019-236p_avtors-kolektiv.pdf.

47 Грищук Ю.В. Міжнародна академічна мобільність в Україні: проблеми та перспективи. Освітологічний дискурс. 2014. Вип. 2. С. 3340. URL : https://core.ac.uk/download/pdf/33686818.pdf.

48 Дубасенюк О.А. Розвиток вищої освіти: тенденції та перспективи. Людиноцентризм як основа гуманітарної політики України: освіта, політика, економіка, культура : матер. Всеукр. конф. К. : ІОД НАПН України, 2011. С. 135-142.

49 Дубасенюк О.А. Розвиток вищої освіти: тенденції та перспективи. Людиноцентризм як основа гуманітарної політики України: освіта, політика, економіка, культура : матер. Всеукр. конф. К. : ІОД НАПН України, 2011. С. 138-139.
} 


\section{Висновки}

1. Інтеграційні процеси вітчизняної освіти і науки до Європейського простору вищої освіти і Європейського дослідницького простору визначають головний пріоритет національної політики, що полягає у розбудові системи розвитку наукового потенціалу країни через призму реалізації потенціалу наукових працівників університетів і створення передумов для кар'єрного шляху дослідників.

Сучасний стан розвитку дослідників свідчить про наявні проблеми і суперечності, що вимагають негайного вирішення на державному та інституційному рівнях. Насамперед, це збільшення фінансування науки і грантової допомоги; визначення пріоритетного статусу професії наукового співробітника; створення системи залучення молоді до наукової сфери і досліджень; модернізація матеріально-технічної бази і інфраструктури університетів тощо.

2. Вітчизняні і зарубіжні праці з досліджуваної проблеми свідчить про актуальність розвитку дослідників. Наявна потреба у створенні передумов реалізації потенціалу дослідників, розвитку здібностей, інтелекту, креативності, наполегливості, відповідальності, передумов саморозвитку. Задоволеність професійною діяльністю і створення умов для реалізації потенціалу у сукупності визначають успішний кар'єрний розвиток дослідника. В цьому аспекті спостерігається посилена мотивація до дослідницької діяльності, сприяння досконалості і якості досліджень, зростає продуктивність праці і ефективність використання результатів наукових досліджень. Звідси слідує, що варто свідомо підходити до вибору професійної діяльності відповідно власних інтересів, можливостей і кар'єрних цінностей ще на початку кар'єрного становлення. Зарубіжний досвід підкреслює важливість співпраці університетів і бізнесу для впровадження результатів наукових досліджень, здійснення розробок відповідно потреб і запитів ринку праці, сприяння комерціалізації наукових здобутків задля фінансової автономії університетів.

3. Обґрунтовано теоретичні основи розвитку дослідників (наукових працівників). Виявлено механізм реалізації потенціалу особистості (потребує розвитку здібностей, інтелекту, креативності, наполегливості, відповідальності, комунікаційний вмінь, здатності до саморозвитку і гнучкості, задоволеності від діяльності, готовності до навчання впродовж життя); механізм академічної мобільності; принцип досконалості, конкурентоспроможність і відкритості наукових досліджень, принцип особистісного цілепокладання, принцип неперервності кар'єрного розвитку; тенденція посилення інтеграції вищої освіти і науки в контексті сучасних викликів розвитку економіки, суспільства і дослідників; тенденція гуманізації вищої освіти; тенденція відкритості науки і результатів наукових досліджень та ін.

4. Реформувати наукову сферу варто відповідно до пріоритетних цілей і напрямів Європейського дослідницького простору для досліджень та інновацій, Європейського простору вищої освіти в аспекті якості і досконалості наукових досліджень та ініціатив «Відкритої науки». Готовність на законодавчому і інституційному рівнях брати зобов'язання щодо підтримки цілей ЄС, зокрема щодо інклюзивності, гендерної рівності та різноманітності в науці; посилення доступу до досконалості досліджень, інновацій та мобільності для дослідників по всьому ЄС; сприяння інвестиціям та проведення реформ у науково-дослідницькій та інноваційній діяльності; поширення процесу комерціалізації результатів наукових досліджень в сектори економіки і виробництва. 


\section{Список використаних джерел}

1. Академічний тлумачний словник. URL : http://sum.in.ua/s/potencial.

2. Вовк О.Р. Провідні тенденції гуманізації освіти: теоретичний аналіз. Наукові записки НДУ ім. М. Гоголя. Психолого-педагогічні науки. 2014. № 1. С. 30-34.

3. Грищук Ю.В. Міжнародна академічна мобільність в Україні: проблеми та перспективи. Освітологічний дискурс. 2014. Вип. 2. С. 33-40. URL : https://core.ac.uk/download/pdf/33686818.pdf.

4. Дослідницькі університети України / Освіта. ua. URL : https://osvita.ua/vnz/glossary/38681/

5. Дубасенюк О.А. Розвиток вищої освіти: тенденції та перспективи. Людиноцентризм як основа гуманітарної політики України: освіта, політика, економіка, культура : матер. Всеукр. конф. К. : ІОД НАПН України. 2011. С. 135-142.

6. Завгородня Є.Є. До проблеми розвитку творчого потенціалу особистості. Неперервна професійна освіта: теорія і практика. 2015. Вип. 4 (45). С. 26.

7. Загородній А. Європейська хмара відкритої науки як глобальний інструмент наукових досліджень. Газета «Cвim». URL : http://www.nas.gov.ua/EN/Messages/Pages/View.aspx?MessagelD=6661.

8. Кількість працівників, задіяних у виконанні наукових досліджень і розробок, за категоріями персоналу (2010-2018рр.) / Головне управління статистики у м. Києві. (Примітка: Дані за 2010-2015 роки включають постійних та тимчасових працівників (сумісників та осіб, які працюють за договорами цивільно-правового характеру, включаючи науково-педагогічних працівників). Починаючи з 2016 року дані наведено без урахування науково-педагогічних працівників, які не виконували наукові дослідження і розробки). URL: http://www.kiev.ukrstat.gov.ua/p.php3?c=3257\&lang=1.

9. Конференція Міністрів вищої освіти Європейського простору вищої освіти «Embrace the challenge, creating new spases, cancelling distance» (19.11.2020 р. Рим, Італія). URL : https://ehea2020rome.it/pages/ehea2020.

10. Коханова О.П., Столярчук О.А. Особистісний потенціал як засіб самореалізації сучасної молоді. URL : http://appsychology.org.ua/data/jrn/v6/i15/22.pdf.

11. Мартиненко С. Європейський простір вищої освіти: тенденції розвитку та пріоритети. Педагогічні витоки освітології. Ч. VІ. С. 165.

12. Марущак В. Творчий потенціал особистості як одна з рушійних сил у розвитку та формуванні вчителя майбутнього. Педагогічні науки: теорія, історія, інноваційні технології. 2016. № 5 (59). С. 327.

13. Парпан У.М. Провідні принципи розвитку сучасної вищої освіти України в контексті євроінтеграції. LEX PORTUS. 2018. № 1 (9). URL : https://core.ac.uk/download/pdf/156902884.pdf.

14. Подшивайлова Ф., Подшивайлова Л. Мотиваційне забезпечення розвитку творчого потенціалу особистості. URL : http://oldconf.neasmo.org.ua/node/2105.

15. Положення про дослідницький університет : проєкт / Міністерство освіти і науки України. URL: https://mon.gov.ua/ua/news/mon-proponuye-dlya-gromadskogo-obgovorennya-proekt-polozhennya-pro-doslidnickijuniversitet.

16. Про вищу освіту : Закон України від 01.07.2014 № 1556-VII. URL : https://zakon.rada.gov.ua/laws/show/155618\#Text.

17. Про внесення змін та визнання такими, що втратили чинність, деяких актів Кабінету Міністрів України : постанова Кабінету Міністрів України від 05.11.2014 № 597. URL : https://zakon.rada.gov.ua/laws/show/597-2014-n\#Text.

18. Про наукову і науково-технічну діяльність : Закон України від 26.12.2015 № 848-VIII. URL : https://zakon.rada.gov.ua/laws/show/848-19\#Text.

19. Семеног О., Вовк М. Академічна культура дослідника в освітньо-культурному просторі університету: монографія. Суми : СумДПУ імені А.С. Макаренка, 2016. 284 с.

20. Скиба Г.В. Сучасний стан науково-технічного потенціалу України: вітчизняні реалії та зарубіжний досвід. Вісник Хмельницького національного університету. 2016, № $6 . \quad$ URL: http://elar.khnu.km.ua/jspui/bitstream/123456789/5357/1/Скибa.pdf.

21. Статистичний щорічник України за 2018 рік / Державна служба статистики України. С. 440. URL: http://www.ukrstat.gov.ua/druk/publicat/kat_u/2019/zb/11/zb_yearbook_2018.pdf.

22. Стратегія розвитку вищої освіти в Україні на 2021-2031 роки. К., 2020.71 с. URL: https://mon.gov.ua/storage/app/media/rizne/2020/09/25/rozvitku-vishchoi-osviti-v-ukraini-02-10-2020.pdf.

23. Чорнойван Г. Теоретичні основи і технології кар'єрного розвитку науково-педагогічних працівників у контексті інтеграції викладацької і дослідницької діяльності. Теоретичні основи і технологія професійного розвитку науково-педагогічних працівників університетів в умовах інтеграції вищої освіти і науки : монографія / авт. кол. К. : Інститут вищої освіти НАПН України, 2019. C. 84-109. URL: https://ihed.org.ua/wpcontent/uploads/2020/04/Tehnologiya prof rozvitku pracivn VNZ Monogr IVO-2019-236p avtors-kolektiv.pdf.

24. Шелестун К.Ю. Умови розвитку й реалізації наукового потенціалу. Наукові праці. Соціологія. 2014. Вип. 222. T. 234. C. $75-76$.

25. Юрченко 3.В. Науковий потенціал особистості: психологічні чинники актуалізації. Вісник Чернігівського національного педагогічного університету. Сер.: Педагогічні науки. 2014. Вип. 115. С. 276-279. 
26. Alves C. Research methodology: How to maximize your research potential. EFORT Open Rev. 2018. V. 3(5). P. 184191. URL: https://www.researchgate.net/publication/325274297 Research methodology How to maximize your research potential.

27. Commission's plan for a new European Research Area based on excellence. URL: https://ec.europa.eu/info/research-and-innovation/strategy/era en.

28. Enhancing the professional development of researchers. URL : https://www.vitae.ac.uk/researchers-professionaldevelopment/about-the-vitae-researcher-development-framework/managers-supervisors-and-the-vitae-researcherdevelopment-framework.

29. European Higher Education Area. URL: https://ec.europa.eu/education/policies/higher-education/bolognaprocess-and-european-higher-education-area en.

30. European Research Area. URL : https://ec.europa.eu/info/research-and-innovation/strategy/era en.

31. Final Draft of the Rome Ministerial Communique.

URL : https://mon.gov.ua/storage/app/media/rizne/2020/11/19/BFUG compressed.pdf.

32. Four strategic objectives European Research Area. URL: https://ec.europa.eu/info/research-andinnovation/strategy/era en.

33. Mirowski Ph., Van Horn R.. The Contract Research Organization and the Commercialization of Scientific Research. Social Studies of Science. 2005. V. 35 Issue 4. P. 503-548.

34. QS World University Rankings (Ukraine, 2020). URL : https://www.topuniversities.com/university-rankings/worlduniversity-rankings/2021.

35. Researcher Development Framework Planner. URL: https://www.vitae.ac.uk/researchers-professionaldevelopment/about-the-vitae-researcher-development-framework-planner.

36. Researcher Development Framework. URL: https://www.vitae.ac.uk/vitae-publications/rdf-related/researcherdevelopment-framework-rdf-vitae.pdf/view.

37. Shanghai Ranking Academic Excellence Survey 2020 Methodology URL: http://www.shanghairanking.com/subject-survey/survey-methodology-2020.html.

38. The European Charter for Researchers The Code of Conduct for the Recruitment of Researchers. C. 22 URL: http://h2020.com.ua/wp-content/uploads/2015/11/Book.pdf.

39. The World University Rankings 2020: methodology. URL: https://www.timeshighereducation.com/worlduniversity-rankings/world-university-rankings-2020-methodology.

40. Times Higher Education (THE) World University Rankings (Ukraine, 2020). URL https://www.timeshighereducation.com/world-university-rankings/2020/worldranking\#!/page/0/length/25/locations/UA/ sort by/rank/sort order/asc/cols/stats.

41. Vitae. Realising the potential of researchers, globally. URL : https://www.vitae.ac.uk/ 


\title{
Розвиток управлінського персоналу університетів України у контексті розширення інституційної автономії: теоретичні основи
}

\author{
Олександр Жабенко, \\ кандидат наук з державного управління, \\ старший науковий співробітник, \\ Відділ інтеграції вищої освіти і науки, \\ Інститут вищої освіти НАПН України, \\ https://orcid.org/0000-0001-5257-1743
}

Анотація. У розділі здійснено аналіз сутності й змісту понять «управлінський персонал університету», «розвиток управлінського персоналу університету»; виявлено принципи і складові розвитку управлінського персоналу, групи компетентностей, що мають бути притаманні управлінському персоналу університету; з’ясовано підходи до оцінювання діяльності управлінського персоналу.

Ключові слова: науково-педагогічні працівники, управлінський персонал, управлінський персонал університету, розвиток управлінського персоналу університету. 


\section{Актуальність проблеми розвитку управлінського персоналу університетів}

Одним із основних завдань освітньої політики України $€$ реалізація принципу розширення інституційної автономії університетів, наслідком якої стане зміна ролі та функцій управлінського персоналу університетів, підвищення вимог до їх розвитку та рівня компетентності. Про це свідчить аналіз документів, що визначають освітню політику.

Так, у «Національній стратегії розвитку освіти в Україні на період до 2021 року» (2013 р.) ${ }^{1}$ завданням розвитку освіти виділено необхідність удосконалення системи підвищення кваліфікації (управлінської культури) керівних кадрів системи освіти, що має базуватись на основі стандартів післядипломної педагогічної освіти.

У Законі України «Про вищу освіту» (2014) ${ }^{2}$ визначено необхідність створення закладами вищої освіти (далі - ЗВО) системи забезпечення якості освітньої діяльності та якості вищої освіти (система внутрішнього забезпечення якості), що повинна забезпечувати підвищення кваліфікації наукових і науковопедагогічних працівників (далі - НПП). Законом НПП, а також і управлінському персоналу: надано право підвищувати кваліфікацію та стажуватися; визначено обов'язком підвищувати професійний рівень, педагогічну майстерність, наукову кваліфікацію; гарантовано створення належних умов для підвищення кваліфікації.

У Законі України «Про наукову і науково-технічну діяльність» (2015) 3 науковим працівникам (до яких віднесено і осіб, які відповідно до трудового договору професійно провадять науково-педагогічну діяльність) надано право підвищувати свою кваліфікацію; визначено обов'язком проходити в установленому порядку атестацію на відповідність займаній посаді, постійно підвищувати свою кваліфікацію.

У Законі України «Про освіту» (2017) ${ }^{4}$ визначено: необхідність створення у закладах освіти системи забезпечення якості (внутрішньої системи забезпечення якості освіти), що може включати критерії, правила і процедури оцінювання управлінської діяльності керівних працівників закладу освіти; право НПП (й, відповідно, управлінського персоналу) на професійний розвиток та підвищення кваліфікації; обов'язок НПп постійно підвищувати свій професійний і загальнокультурний рівні.

У "Порядку підвищення кваліфікації педагогічних і науково-педагогічних працівників» (2019) ${ }^{5}$ визначено, що НПП зобов'язані постійно підвищувати свою кваліфікацію як в Україні так і за кордоном не рідше одного разу на п'ять років. Крім того, встановлено, що керівники (посади яких відносяться до категорії НПП), які вперше призначені на відповідну посаду, обов'язково проходять підвищення кваліфікації відповідно до займаної посади протягом двох перших років перебування на посаді.

У проєкті «Стратегії розвитку вищої освіти в Україні на 2021-2031 рр.» (2020) ${ }^{6}$ передбачено: зобов'язати НПП самостійно підтримувати свої знання та навички в актуальному стані; покращити управління ЗВО через запровадження контрактів із ректорами, що містять цільові показники діяльності зВО (хоча ця норма вже є у Законі «Про вищу освіту»); розвиток системи безперервної освіти та навчання протягом життя.

Увага, що приділяється питанням розвитку керівних кадрів системи освіти в документах, що визначають освітню політику, свідчить про необхідність і важливість процесу розвитку управлінського персоналу університетів та визначає його актуальність.

\footnotetext{
1 Національна стратегія розвитку освіти в Україні на період до 2021 року, схвалена Указом Президента України від 25.06 .2013 № 344/2013. URL : https://zakon.rada.gov.ua/laws/show/344/2013\#Text.

2 Про вищу освіту : Закон України від 01.07.2014 № 1556-VII. URL : https://zakon.rada.gov.ua/laws/show/1556-18\#Text.

3 Про наукову і науково-технічну діяльність : Закон України від 26.11.2015 № 848-VIII. URL : https://zakon.rada.gov.ua/laws/show/848-19\#Text.

4 Про освіту : Закон України від 05.09.2017 № 2145-VIII. URL : https://zakon.rada.gov.ua/laws/show/2145-19\#n2093.

5 Порядок підвищення кваліфікації педагогічних і науково-педагогічних працівників, затверджений постановою Кабінету Міністрів України від 21.08.2019 № 800. URL : https://zakon.rada.gov.ua/laws/show/800-2019-п\#Text.

${ }^{6}$ Стратегія розвитку вищої освіти в Україні на 2021-2031 рр. : проєкт, підготовл. на вик. Указу Президента України «Про вдосконалення вищої освіти в Україні» від 03.06.2020 № 210/2020. 71 с. URL : https://mon.gov.ua/storage/app/media/rizne/2020/09/25/rozvitku-vishchoiosviti-v-ukraini-02-10-2020.pdf.
} 


\section{Аналіз останніх вітчизняних і зарубіжних публікацій, дотичних до проблеми дослідження}

Аналіз наукових джерел засвідчив, що науковці приділяли увагу різним сторонам розвитку управлінського персоналу. Так, загальні питання організації професійного розвитку керівників закладів вищої освіти розглядали: B. Петков; N. Burquel; G. Copland; I.D. Losinger.

В. Петков у праці «Професійний розвиток керівників вищих навчальних закладів як успадкована проблема науки державного управління» ${ }^{7}$ досліджував діяльність органів державного управління 3 професійного розвитку керівників 3ВО, аргументував необхідність селекції керівників та ефективного управління професійним розвитком керівників. Учений стверджує, що більшість теперішніх керівників 3 вО не вивчала управлінських дисциплін під час здобуття вищої фахової освіти й, відповідно, не має необхідних управлінських компетентностей. Тому вони можуть самовдосконалюватися (якщо є внутрішня потреба чи бажання) та підвищувати кваліфікацію керівника ЗВО (яку не здобували) один раз на п'ять років. Серед проблем професійного розвитку керівників В. Петков акцентує увагу на відсутності державної політики й недосконалості нормативного регулювання питань професійного розвитку керівників ЗВО, моніторингу їх діяльності.

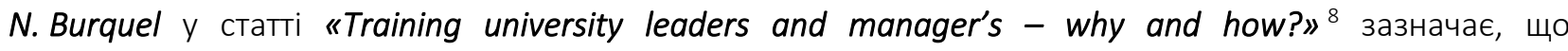
трансформації, спрямовані на підвищення ефективності діяльності закладів вищої освіти, вимагають підвищення професійного рівня в управлінні всіма службами закладу. Тому є постає потреба у запровадженні сучасних механізмів управління, що передбачають постійний професійний розвиток університетських керівників та менеджерів.

На думку G. Copland ${ }^{9}$, управлінці вищого рівня університетів повинні мати обов'язки директорів компаній, оскільки частка фінансування університетів із державного бюджету із кожним роком зменшується. Тому й керівний орган повинен діяти у формі «ради директорів», що свідчитиме про посилення відповідальності управлінців за забезпечення ефективного управління установою й планування ії подальшого розвитку. При цьому члени правління, обов'язково повинні мати навички та досвід, достатні для виконання правлінням своїх основних обов'язків та забезпечення довіри зацікавлених сторін.

I.D. Losinger у статті «The Development of University Leaders: Supporting the Professional Development Needs of University Presidents» ${ }^{10}$ звертає увагу, що традиційно кар'єрний шлях керівника університету включає поступове проходження через присвоєння академічних звань до посад завідувача кафедри, декана та віце-президента. Перевагою цього шляху $\epsilon$ те, що він передбачає поступове введення керівника до зростаючої адміністративної, фінансової та політичної складності. Однак, при врахуванні викликів та проблем, що виникають у діяльності керівників, традиційне проходження академічної кар'єри може бути недостатньою підготовкою до виконання ролі керівника 3ВО, а керівники повинні мати відповідні навички.

Ми цілком розділяємо думку авторів, що керівники університетів повинні мати відповідні знання, уміння і навички для виконання своїх обов'язків.

А. Грушева, О. Пілевич; Л. Бєлова; C. Калашнікова; Sh. Ben-Hur, J.-L. Barsouх досліджували проблеми підготовки управлінського персоналу, розвитку компетентностей у процесі підготовки майбутніх керівників, зосереджували увагу на підготовці представників лише одного еволюційного рівня майбутніх керівників управлінців-лідерів.

Так, А.Грушева, О. Пілевич у статті «Формування управлінської компетентності майбутніх економістів у культурно-освітньому середовищі вищого навчального закладу» ${ }^{11}$ запропонували модель формування управлінської компетентності майбутніх менеджерів та шляхи їі запровадження в культурно-

\footnotetext{
7 Петков В.3. Професійний розвиток керівників вищих навчальних закладів як успадкована проблема науки державного управління. Державне управління: удосконалення та розвиток. 2010. № 4. URL : http://www.dy.nayka.com.ua/?op=1\&z=126.

${ }^{8}$ Burquel N. Training university leaders and manager's - why and how? Leadership and Governance in Higher Education. 2012. Vol. № 1. 15 p. URL : https://www.academia.edu/15170512/Training_Leaders and Managers in Higher_Education.

${ }^{9}$ Copland G. Governance in a changing environment: thought-piece. Contemporary issues in governance. June $2014.26 \mathrm{p}$. URL: https://www.advance-he.ac.uk/knowledge-hub/governance-changing-environment-thought-piece.

10 Losinger I.D. The Development of University Leaders: Supporting the Professional Development Needs of University Presidents. Adult Education and the Contested Terrain of Public Policy: Proceedings of the Annual Conference of the Canadian Association for the Study of Adult Education (21st, Toronto, Ontario May 30-31 and June 1, 2002). $2002 . \quad 438$ p. P.374-376. URL: https://files.eric.ed.gov/fulltext/ED478964.pdf.

${ }_{11}$ Грушева А.А., Пілевич О.А. Формування управлінської компетентності майбутніх економістів у культурно-освітньому середовищі вищого навчального закладу. Оновлення змісту, форм та методів навчання і виховання в закладах освіти. 2017. Вип. 16. С. 203207. URL: http://nbuv.gov.ua/UJRN/Ozfm 20171663.
} 
освітнє середовище 3ВО.

Л. Бєлова у статті «Підготовка управлінських кадрів для національної освітньої системи» ${ }^{12}$ звертає увагу на якість підготовки управлінських кадрів вищого рівня в освітній галузі. На ї̈ думку, управлінським кадрам має бути притаманні високі моральні риси, професійні навички (аналізу й формування освітньої політики, програм стратегічного управління тощо.

С. Калашнікова у докторській дисератції «Теоретико-методологічні засади професійної підготовки управлінців-лідерів в умовах сучасних суспільних трансформацій» ${ }^{13}$ обгрунтовує теоретико-методологічні основи професійної підготовки управлінців-лідерів у закладах освіти та визначає закономірності, принципи, зміст, педагогічну технологію, процедуру оцінювання та умови ефективності як основні складові методології професійної підготовки управлінців-лідерів. Для розвитку лідерського потенціалу основний акцент має здійснюватися на розвитку таких якостей як цілеспрямованість, прогностичність (передбачливість), аналітичність, адаптивність, стратегічне мислення, спрямованість на розвиток (саморозвиток), емоційний інтелект, людяність.

Sh. Ben-Hur та J.-L. Barsoux у праці «Betting on leadership development: three false paths» ${ }^{14}$ звертають увагу та той факт, що розвиваючи лідерські якості, організації можуть створити важко відтворюване джерело конкурентних переваг на основі людських (а саме управлінських) ресурсів. У цьому аспекті, організації, завдяки розумному поєднанню освітніх програм та процесів, можуть сформувати більш ефективних лідерів. Проте, це передбачає, що організації: чітко розуміють, як формувати лідерів; здатні слідувати за сформованими ними ж лідерами; впевнені, що компетентності, які вони мають намір розвивати у лідерів, це ті, які їм будуть потрібні через 5-10 років. У зв'язку з цим, на даний час ще не існує гарантованого рецепту успішного розвитку лідерських якостей.

Питання формування і розвитку компетентностей діючих керівників 3ВО були предметом досліджень O. Гуменного; Г. Єльникової; M. Blaskova, R. Blasko, E. Matuska, J. Rosak-Szyrocka. Вчені зосереджують увагу на переважанні самоосвіти у процесі розвитку управлінського персоналу.

О. Гуменний у монографії «Розвиток інформаційної культури керівників вищих навчальних закладів» ${ }^{15}$ акцентує увагу на розвитку інформаційної культури керівників 3ВО. На думку вченого, високий рівень інформаційної культури дозволить здійснювати ефективну управлінську діяльність на інформаційному, аналітичному, практичному рівнях. О.Гуменний запропонував концепцію самостійної освіти (основні положення якої співвідносяться із концепцією безперервної освіти), відповідно до якої у центрі самостійного навчання знаходиться керівник 3ВО, який усвідомлено і самостійно керує процесом свого навчання.

Г. Єльникова у статті «Компетентнісний підхід до моделювання професійної діяльності керівника вищого навчального закладу» ${ }^{16}$ сформувала модель фахової компетентності керівника ЗВО, у якій систематизувала всі характеристики керівника. На основі характеристик керівника виділила кваліметричну модель професійної компетентності керівника ЗВО, спрямовану на для оцінювання компетентності керівника. Зазначені моделі, на думку Г. Єльникової, дозволять керівнику зВО здійснювати самоаналіз, саморегулювання й саморозвиток професійної компетентності. Проте, запропоновані моделі стосуються ректорів і у деякій мірі проректорів, та не стосуються деканів (директорів навчально-наукових інститутів), завідувачів кафедр.

M. Blaskova, R. Blasko, E. Matuska, J. Rosak-Szyrocka у праці «Development of Key Competences of University Teachers and Managers» ${ }^{17}$ запропонували для розвитку компетентностей управлінців застосовувати методи і прийоми розвитку викладацької компетентності (коучинг, наставництво, консультації та перевірка

\footnotetext{
12 Бєлова Л. Підготовка управлінських кадрів для національної освітньої системи. Новий Колегіум. 2016. C. 27-29. URL: http://nbuv.gov.ua/UJRN/NovKol_2016_2_8.

13 Калашнікова С.А. Теоретико-методологічні засади професійної підготовки управлінців-лідерів в умовах сучасних суспільних трансформацій : дис. ... д-ра пед. наук : 13.00.06 ; ДВН3 «Ун-т менедж. освіти» HAПН України. К., 2011.462 с. URL: https://lib.iitta.gov.ua/8664/1/2011_CK_докторська_дисератція.pdf.

${ }^{14}$ Ben-Hur Sh., Barsoux J.-L. Betting on leadership development: three false paths / Real Learning. Real Impact. Research\&Knowledge. 2014. URL : https://www.imd.org/research-knowledge/articles/betting-on-leadership-development-three-false-paths/

15 Гуменний О.Д. Розвиток інформаційної культури керівників вищих навчальних закладів : монографія. Київ : Міленіум, 2015.245 с. URL : https://lib.iitta.gov.ua/11259/1/монографія_03 11 15 15 1_hruden.pdf.

16 Єльникова Г.В. Компетентнісний підхід до моделювання професійної діяльності керівника вищого навчального закладу. Теорія та методика управління освітою. 2010. № 4. URL : http://tme.umo.edu.ua/docs/4/10elneel.pdf.

17 Blaskova M., Blasko R., Matuska E., Rosak-Szyrocka J. Development of Key Competences of University Teachers and Managers. ProcediaSocial and Behavioral Sciences. 2015. URL : https://www.researchgate.net/publication/277949648 Development of Key Competences of University Teachers and Managers.
} 
досвідченими авторитетними освітянами), професійної компетентності (участь у закордонних академічних та інших стажуваннях і стипендіях), комунікаційної компетентності (ведення «журналу спілкування», тренування навичок спілкування тощо). Також для розвитку потенціалу особливо початківців, пропонують застосовувати метод нейролінгвістичного програмування.

На розвиток резерву управлінського персоналу звертали увагу переважно учені-економісти. Наприклад, О.Гусаров у статті «Особливості розвитку управлінського персоналу в ієрархічних організаційних системах» ${ }^{18}$ виділяв особливості розвитку резерву управлінського персоналу в ієрархічних організаційних системах. Учений визначає коло осіб, які складають кадровий резерв, та поділяє кадровий резерв на дві групи: розвитку та функціонування. Учені-педагоги не акцентують увагу на розвитку управлінського резерву. Можливо, це пов'язано із запровадженням конкурсного набору претендентів на посади НПП (в умовах конкурсу статус «резервіста» не дає ніякої переваги).

Важливим індикатором розвитку управлінського персоналу $\epsilon$ оцінювання їх діяльності. Цьому питанню приділяли увагу: М. Жиленко; М. Морозова; Л. Згалат-Лозинська.

М. Жиленко у статті «Оцінка ефективності управлінської діяльності керівника закладу вищоі освіти» ${ }^{19}$ досліджував ефективність управлінської діяльності керівника закладу вищої освіти. Учений вважає, що ефективність управління залежить від обґрунтованих вимог до відбору керівників та використання їх професійних можливостей, виваженої державної кадрової політики щодо керівників ЗВО. М. Жиленком визначено 17 основних критеріїв, що дозволять з'ясувати ефективність системи управління ЗВО та визначити зміст спеціальної (управлінської) підготовки для керівника.

М. Морозова у праці «Особливості управління персоналом у вищому навчальному закладі» 20 аналізувала управлінську діяльність у закладі вищої освіти та обґрунтовувала шляхи формування системи управління персоналом, що інтерпретується ученою як запорука ефективного розвитку закладу вищої освіти, вибору найоптимальніших шляхів подолання кризових ситуацій.

Більш детально питання оцінки розглядалося Л. Згалат-Лозинською у статті «Методи оцінки ефективності розвитку управлінського персоналу підприємства» ${ }^{21}$, яка досліджувала й систематизувала підходи до оцінки ефективності процесу розвитку управлінського персоналу підприємства та класифікувала підходи і показники цього процесу. Л. Згалат-Лозинська виділяє різні підходи до оцінки ефективності розвитку управлінського персоналу, що різняться методикою розрахунку залежно від сфери застосування: за економічним ефектом (в економіці); за результативністю педагогічної діяльності (у педагогіці); за готовністю до реалізації менеджерських функцій, знаннями, навичками, соціальною й організаційною ефективністю (у психології управління).

Аналіз джерел засвідчив, що переважна більшість наукових праць зосереджена на розгляді різних аспектів: загальних питань організації професійного розвитку керівників закладів вищої освіти, проблемах підготовки управлінського персоналу, формуванні й розвитку компетентностей керівників закладів вищої освіти та оцінюванні діяльності керівників.

\footnotetext{
18 Гусаров О.О. Особливості розвитку управлінського персоналу в ієрархічних організаційних системах. Економіка та суспільство. 2017. № 8. C. 236-239. URL : http://www.economyandsociety.in.ua/journal/8 ukr/41.pdf.

19 Жиленко М. Оцінка ефективності управлінської діяльності керівника закладу вищої освіти. Вісник Київського національного університету імені Тараса Шевченка. Сер.: Педагогіка. $2018 . \quad$ № 1 (7). C. 11-14. URL: http://pedvisnyk.knu.ua/index.php/pedvisnyk/article/view/43/41.

${ }^{20}$ Морозова М.Е. Особливості управління персоналом у вищому навчальному закладі. Теорія та методика управління освітою. 2015. № 1 (15). URL: http://nbuv.gov.ua/UJRN/ttmuo 2015120.

21 Згалат-Лозинська Л.О. Методи оцінки ефективності розвитку управлінського персоналу підприємства. Ефективна економіка. 2017. № 12. URL : http://www.economy.nayka.com.ua/?op=1\&z=6813.
} 


\section{Визначення теоретичних основ дослідження}

\section{Категоріальний апарат дослідження проблеми розвитку управлінського персоналу}

Наше дослідження буде базуватися на таких основних поняттях: «управлінський персонал», «управлінський персонал університету», «розвиток управлінського персоналу університету».

Сьогодні не існує загальноприйнятного однозначного тлумачення поняття «управлінський персонал», а й до того ж часто використовуються різні синонімічні назви («адміністрація», «керівники» і «управлінці»). Проте, у теорії управління визнано, що «поняття «управління» ширше за поняття «керівництво», адже керівництво можна розглядати як складову частину, елемент управління, або його функцію» ${ }^{22}$. Те ж стосується і співвідношення понять «адмініструвати» і «управляти». У цьому випадку поняття «управляти» ширше по відношенню до поняття «адмініструвати», яке більше характеризує методи управління «керувати бюрократично, за допомогою наказів і розпоряджень» ${ }^{23}$.

Досить часто як синоніми використовуються поняття «кадри» і «персонал». Проте, на нашу думку, ці поняття відмінні. Кадри - це штатні кваліфіковані працівники з певною професійною підготовкою, які мають спеціальні знання, трудові навички чи досвід роботи у вибраній сфері діяльності ${ }^{24}$. Поняття «кадри» розуміється як «основний (штатний) склад робітників установи, підприємства тощо» 25;26. Воно часто ототожнюється лише із частиною працюючих - спеціалістами або робітниками високої кваліфікації і стажем роботи на даному підприємстві ${ }^{27}$.

Що стосується поняття «персонал», то воно розуміється або як «особовий склад установи, підприємства або частина цього складу, що становить групу, утворену за фаховими чи іншими ознаками» ${ }^{28}$, або у значенні «особовий склад, колектив працівників якої-небудь установи, підприємства тощо; група робітників установи, підприємства, що працюють в одному відділі, на одній ділянці роботи або виконують ті самі функції, мають той самий фах» ${ }^{29}$. Поняття «персонал» має характерні ознаки: наявність трудового договору для оформлення трудових взаємовідносин із роботодавцем; володіння певними якісними характеристиками, поєднання особистих та організаційних цілей ${ }^{30}$.

На нашу думку, поняття «кадри» - це поняття більше знеособлене, обліково-статистичне, що дозволяє кількісно характеризувати штат працівників організації за певними ознаками: професійною підготовкою; здобутою кваліфікацією; трудовими навичками; досвідом роботи; виконанням певних функцій в організації. Поняття «персонал» - це поняття, що охоплює конкретних осіб, які працюють в організації, й дозволяє характеризувати працівників «за «кількістю, структурою, професійною придатністю, компетентністю» ${ }^{31}$, функціональними обов'язками, особистісними якостями. Поняття «персонал» дозволяє більш комплексно характеризувати працівників організації відповідно до ділянок роботи та виконуваних функцій. Тому, в нашому дослідженні ми будемо використовувати поняття управлінський персонал й розуміти його як категорію осіб, які працюють в установі, наділених повноваженнями виконувати управлінські фуннкиіі й відповідальністю за результативність роботи підлеглих та керованих ними структур ${ }^{32 ; 33 ; 34 ; 35 ; 36 ; 37 .}$

\footnotetext{
22 Гончарук Н.Т. Управління керівним персоналом у сфері державної служби України: теорія та практика : монографія. Д. : ДРІДУ НАДУ, 2012. 343 с. С. $24,25$.

${ }^{23}$ Словник української мови : в 11 томах. 1970. Т. 1. С. 21. URL : http://sum.in.ua/s/administruvaty.

24 Управління персоналом (2003). URL : https://library.if.ua/book/45/3054.html.

${ }^{25}$ Словник іншомовних слів: 23000 слів та термінологічних словосполучень / уклад. Л.О. Пустовіт та ін. К. : Довіра, 2000.1018 с. С. 491.

${ }^{26}$ Словник української мови : в 11 томах. 1975. T. 6. С. 69. URL : http://sum.in.ua/s/kadry.

27 Управління персоналом (2003). URL : https://library.if.ua/book/45/3054.html.

${ }^{28}$ Словник іншомовних слів: 23000 слів та термінологічних словосполучень / уклад. Л.О. Пустовіт та ін. К. : Довіра, 2000.1018 с. С. 729.

${ }^{29}$ Словник української мови : в 11 томах. 1975. Т. 6. С. 331. URL : http://sum.in.ua/s/personal.

30 Управління персоналом (2003). URL : https://library.if.ua/book/45/3054.html.

31 Управління персоналом (2003). URL : https://library.if.ua/book/45/3054.html.

32 Новий тлумачний словник української мови : у 4 т. / В. Яременко, О. Сліпушко. К. : Вид-во «Аконіт», 2000. Т. 2. 911 с. С. 240.

33 Дяків О.П., Островерхов В.М. Управління персоналом : навч.-метод. посіб. (вид. друге, переробл. і доповн.). Тернопіль : ТНЕУ, 2018. 288 с. C. 25. URL : http://dspace.wunu.edu.ua/bitstream/316497/33638/1/Посібник 2018 УП-верстка_1 (1).pdf.

34 Положення (стандарт) бухгалтерського обліку 23 «Розкриття інформації щодо пов'язаних сторін», затверджене наказом Міністерства фінансів України від 18.06.2001 № 303, зареєстроване в Міністерстві юстиції України 23.06.2001 за № 539/5730. URL: https://ips.ligazakon.net/document/view/reg5730?an=210\&ed=2013 0627.

35 Управління персоналом / Library.if.ua. 2003. URL : https://library.if.ua/book/45/3054.html.

36 Чумаченко О.В., Шульгіна Т.С. Проблеми визначення категорії «управлінський персонал підприємства» та його класифікації. Сталий розвиток економіки. 2011. № 2(5). С. 57-62.C. 59. URL : https://uniep.km.ua/pdf/ 2 2011.pdf.
} 
Наступним є поняття «управлінський персонал університету». Робота управлінського персоналу в університеті передбачає наявність у його представників відповідних якісних характеристик, необхідних для роботи саме в університеті (компетентностей, науково-педагогічних здобутків, досвіду роботи тощо). Тому, базуючись на попередньому визначенні поняття «управлінський персонал» ми будемо застосовувати поняття у значенні: управлінський персонал університету - категорія працівників університету, які мають визначені якісні характеристики, наділені повноваженнями виконувати управлінські функції й відповідальністю за результативність роботи підлеглих та керованих ними структур. Посади управлінського персоналу університетів визначено у нормативних документах $38 ; 39 ; 40 ; 41 ; 42$.

Значна частина управлінського персоналу університету відноситься до категорії «науково-педагогічні працівники» 43: "(ректор університету, його заступники (проректори з навчальної, наукової, виховної і господарської роботи; декани факультетів; завідувачі кафедр), які спеціально підготовлені до успішного керування людьми ... і виступають як суб'єкт управління цілісною ... системою - професійною діяльністю НПП та допоміжного персоналу» ${ }^{44}$. Основною відмінністю цієї групи працівників від інших є належність до складу апарату управління та реалізація («на адміністративному, фінансово-економічному, соціальнопсихологічному і особистісно-орієнтованому рівнях» ${ }^{45}$ ) функцій управління (адміністративно-розпорядчих), прийняття управлінських рішень («мають повноваження приймати рішення і керують (видають накази, розпорядження, дають вказівки, обов'язкові для відповідних виконавців) їх втіленням у практику» 46; 47; 48).

Університет - організація ієрархічного типу. У таких організаціях управлінський персонал поділяють відповідно до рівня і місця в загальній системі управління на керівників 49; 50:

- вищого рівня (керівник університету, заступники керівника університету) - відповідають за прийняття найважливіших для університету рішень;

- середнього рівня (керівник філіалу, заступники керівника філіалу, декан (начальник) факультету, його заступники, керівники управлінь тощо), діяльність яких полягає у підготовці інформації для прийняття рішень керівниками вищого рівня і доведені прийнятих рішень у вигляді конкретних завдань керівникам низового (оперативного) рівня;

- низового (оперативного) рівня (завідувач (начальник) кафедри, керівник відділу тощо), діяльність якого спрямована на створення умов для виконання визначених завдань, повного використання робочого часу співробітниками, заохочення творчої активності у процесі праці. Робота керівника низової ланки контролюється і координується керівниками середньої ланки.

\footnotetext{
${ }^{37}$ Netherlands. Management and Other Education Staff / European Commission. Eurydice. URL : https://eacea.ec.europa.eu/nationalpolicies/eurydice/content/management-and-other-education-staff-47_en

38 Про вищу освіту : Закон України від 01.07.2014 № 1556-VII. URL : https://zakon.rada.gov.ua/laws/show/1556-18\#Text.

39 Перелік посад педагогічних та науково-педагогічних працівників, затверджений постановою Кабінету Міністрів України від 14.06.2000 № 963. URL : https://zakon.rada.gov.ua/laws/show/963-2000-п\#Text.

40 Національний класифікатор України: Класифікатор професій ДК 003:210, затверджений наказом Держспоживстандарту України від 28.07.2010 № 327 (редакція від 15.02.2019). URL : https://zakon.rada.gov.ua/rada/show/va327609-10\#Text.

41 Про затвердження Інструкції про оплату праці та розміри ставок заробітної плати професорсько-викладацького складу вищих навчальних закладів : наказ Міністерства освіти України від 02.04.1993 № 90, зареєстрований у Міністерстві юстиції України 03.12.1993 за № 181. URL : https://zakon.rada.gov.ua/laws/show/z0181-93\#Text.

42 Про впорядкування умов оплати праці та затвердження схем тарифних розрядів працівників навчальних закладів, установ освіти та наукових установ : наказ Міністерства освіти і науки України від 26.09.2005 № 557, зареєстрований у Міністерстві юстиції України 03.10.2005 за № 1130/11410. URL : https://zakon.rada.gov.ua/laws/show/z1130-05\#Text.

43 Про вищу освіту : Закон України від 01.07.2014 № 1556-VII. URL : https://zakon.rada.gov.ua/laws/show/1556-18\#Text.

44 Педагогічнй менеджмент: данина моді чи потреба часу?

https://m.pidru4niki.com/12991010/pedagogika/pedagogichniy menedzhment danina modi_potreba_chasu.

45 Жиленко М. Оцінка ефективності управлінської діяльності керівника закладу вищої освіти. Вісник Київського національного університету імені Тараса Шевченка. Сер.: Педагогіка. $2018 . \quad$ № 1 (7). C. 11-14. C. 12. URL http://pedvisnyk.knu.ua/index.php/pedvisnyk/article/view/43/41.

46 Управлінські кадри. Економічна енциклопедія : у трьох томах / редкол.: С.В. Мочерний (відп. ред.) та ін. К. : Видавничий центр «Академія», 2000. T. 1. 864 c. URL : http://www.ukr.vipreshebnik.ru/entsiklopediya/65-u/2873-upravlinski-kadri.html.

47 Малиновський В.Я. Словник термінів і понять з державного управління. Вид. 2-ге, доп. і виправл. К. : Центр сприяння інституційному розвитку державної служби, 2005. 254 с. С. 202.

48 Кадри управління. Класифікація та характеристика. URL : https://studfile.net/preview/5043643/

${ }^{49}$ Міщенко І.А. Значення категорії «управлінські кадри» та становлення наукового змісту їх діяльності». Ефективна економіка. 2014. № 10. URL : http://www.economy.nayka.com.ua/?op=1\&z=3434.

50 Кадри управління. Класифікація та характеристика. URL : https://studfile.net/preview/5043643/
} 
За кордоном управлінський персонал (managerial staff) поділяється на ${ }^{51}$ :

- вищий (senior / top) керівний персонал - ректор (rector);

- середній (middle) керівний персонал (managerial staff) - проректори (pro-rectors) та завідувачі кафедр (heads of department).

Проте, $є$ інший варіант такого поділу. Наприклад, у Нідерландах управлінський персонал університету поділяється ${ }^{52}$ :

- вищий керівний персонал - 3-5 членів наглядової ради (supervisory board);

- середній керівний персонал - до 3-х членів виконавчої ради / правління (executive board), до складу якої входить і ректор (rector);

- низовий рівень (рівень факультету (faculty level) - декани факультетів.

Відповідно до «Класифікатора професій» ДК 003:2010 «професійні назви роботи» (що відповідають посадам управлінського персоналу університету) відносяться до:

класу 121 «Керівники підприємств, установ та організацій» (підклас 1210 «Керівники підприємств, установ та організацій», група 1210.1 «Керівники підприємств, установ та організацій»);

класу 122 «Керівники виробничих та інших основних підрозділів» (підклас 1229 «Керівники інших основних підрозділів», групи 1229.4 «Керівники підрозділів у сфері освіти та виробничого навчання, 1229.6 «Керівники підрозділів у сфері культури, відпочинку та спорту»);

класу 123 «Керівники функціональних підрозділів) ${ }^{53}$.

У нашому дослідженні буде акцентуватися увага на дослідженні управлінського персоналу університету, який, з одного боку бере безпосередню участь у формуванні науково-педагогічного потенціалу університету, а з іншого, одночасно з цим складає науково-педагогічний потенціал університету.

Управлінський персонал має певний обсяг навантаження, що включає в себе не лише різноманітні функції, а й певну кількість підлеглих, так званий діапазон управління / адміністративна місткість (кількість осіб, які $€$ / можуть бути в безпосередньому підпорядкуванні керівника). Найбільш прийнятною $є$ група з п'яти осіб. У такій групі на прийняття рішень витрачається менше часу, а до її керівника не висувають вимог, що постають перед керівником великої групи ${ }^{54}$ (наприклад, мінімальний склад кафедри ${ }^{55}$ визначено 3 урахуванням підходу до формування самостійного відділу на державній службі ${ }^{56}$ ).

Наступне поняття, що буде використовуватися нами у дослідженні - «розвиток управлінського персоналу університету». На основі визначення понять «професійний розвиток НПП» 57 і «професійний розвиток управлінців-лідерів» ${ }^{58}$ під розвитком управлінського персоналу університету будемо вважати безперервну, цілеспрямовану реалізацію потенціалу управлінського персоналу університету через оновлення, розвиток й удосконалення компетентностей, збагачення досвіду, шляхом неперервної профресійної освіти (вища освіта, післядипломна освіта, підвищення кваліфікації тощо), самоосвіти та професійної діяльності відповідно до цілей і завдань діяльності університету. Ключовим елементом $\epsilon$ формування плану індивідуального розвитку, що регулярно переглядається та оновлюється.

Аналіз нормативних документів дозволив нам виділити дві тенденції у розвитку управлінського персоналу університетів:

- запровадження обов'язкового підвищення кваліфікації представників управлінського персоналу,

\footnotetext{
51 Ukraine Higher Education Leadership Development Programme. URL : https://www.britishcouncil.org.ua/en/programmes/education/pastprojects/leadership-development.

52 Netherlands. Management Staff for Higher Education / European Commission. Eurydice. URL : https://eacea.ec.europa.eu/nationalpolicies/eurydice/content/management-staff-higher-education-47 en.

53 Національний класифікатор України: «Класифікатор професій» ДК 003:2010. К.: Вид-во «Соцінформ», 2010. URL: https://dovidnyk.in.ua/directories/profesii/id/

54 Кадри управління. Класифікація та характеристика. URL : https://studfile.net/preview/5043643/

55 Про вищу освіту : Закон України від 01.07.2014 № 1556-VII. URL : https://zakon.rada.gov.ua/laws/show/1556-18\#Text.

56 Про упорядкування структури апарату центральних органів виконавчої влади, їх територіальних підрозділів та місцевих державних адміністрацій : постанова Кабінету Міністрів України від 12.03.2005 № 179. URL : https://zakon.rada.gov.ua/laws/show/179-2005-п\#Text.

57 Жабенко О. Професійний розвиток науково-педагогічних працівників університетів в умовах інтеграції вищої освіти і науки: моделі і технологія. Теоретичні основи і технологія професійного розвитку науково-педагогічних працівників університетів в умовах інтеграції вищої освіти і науки : монографія / авт. кол. К. : Інститут вищої освіти НАПН України, 2019.236 c. С. 40-83. С. 43. URL : https://ihed.org.ua/wp-content/uploads/2020/04/Tehnologiya prof rozvitku pracivn VNZ Monogr IVO-2019-236p avtors-kolektiv.pdf.

58 Калашнікова С.А. Теоретико-методологічні засади професійної підготовки управлінців-лідерів в умовах сучасних суспільних трансформацій : дис. ... д-ра пед. наук : 13.00.06 ; ДВН3 «УН-т менедж. освіти» HAПН України. К., 2011. 462 с. С. 282. URL: https://lib.iitta.gov.ua/8664/1/2011 СК докторська дисератція.pdf.
} 
які вперше призначені на посаду, згідно із займаною посадою протягом двох перших років роботи (відсутність в управлінського персоналу університетів спеціальної освіти для здійснення функціональних обов'язків має компенсуватися обов'язковим підвищенням кваліфікації новопризначених представників управлінського персоналу протягом перших двох років роботи ${ }^{59}$;

- створення умов для забезпечення розвитку науково-педагогічних працівників (й управлінського персоналу), відповідно до потреб особистості, а не потреб закладу вищої освіти. Так, НПП гарантовано створення належних умов для підвищення кваліфікації, що забезпечується їх засновниками та органам управління 3ВО. А конкретні форми, види, напрями та суб'єктів надання освітніх послуг із підвищення кваліфікації НПП обирають самостійно. Крім того, НПП повинні самостійно підтримувати свої знання та навички в актуальному стані ${ }^{60}$. При цьому, на нашу думку, не завжди можуть бути враховані потреби 3 Во щодо вдосконалення персоналу з відповідних напрямів діяльності закладу.

Процес розвитку управлінського персоналу спрямовується на формування управлінців, здатних вчасно реагувати на мінливі умови освітньо-наукового процесу, й містить сукупність принципів, методів, форм, організаційного механізму із розробки цілей і завдань, спрямованих на збереження, зміцнення й збільшення управлінського потенціалу, на удосконалення компетентностей управлінського персоналу ${ }^{61}$.

Професійний розвиток управлінського персоналу може здійснюватися шляхом формальної, неформальної та інформальної освіти, передбачає постійну самоосвіту, участь у програмах підвищення кваліфікації та будь-яких інших видах і формах професійного зростання ${ }^{62}$.

У Європі для професійного розвитку управлінського персоналу пропонуються короткі програми керівного та управлінського розвитку, програми вищого рівня з управління вищою освітою та інші форми навчання, такі як коучинг та навчання із колегами ${ }^{63}$.

Досить часто розвиток керівника вбачають у його професійній діяльності, що включає публічні виступи, комунікацію між керівниками органів та установ різного рівня, переговори та вирішення конфліктів, формулювання політики закладу та залучення ресурсів тощо. Для розвитку відповідних навичок створюються програми. Однак, більш продуктивним $€$ розвиток керівників поза офіційним середовищем курсів та семінарів. Наприклад, через «networking and similar support strategies» (коли самі керівники підтримують один одного та обмінюються досвідом, допомагають дізнатися про різні професійні проблеми), що є більш ефективною допомогою для розвитку. Спеціалізована література, відвідування конференцій та програм навчання є додатковими засобами для розвитку ${ }^{64}$.

\section{Принципи розвитку управлінського персоналу університету}

Кадрова політика щодо управлінського персоналу університету будується на теоретичних положеннях, що виступають як принципи, основні положення для втілення її в життя. Принципи відображають особливості, на яких базується розвиток управлінського персоналу ${ }^{65}$. Виходячи 3 цього, принципи містять вимоги як щодо особистих якостей персоналу, так і організації роботи з ними. Наприклад, можна виділити дві основні групи принципів ${ }^{66}$ :

- загальні (базисні), що призначені для формування кадрового потенціалу: системності, рівних можливостей, поваги до людини, командної єдності, правового та соціального захисту;

\footnotetext{
59 Порядок підвищення кваліфікації педагогічних і науково-педагогічних працівників, затверджений постановою Кабінету Міністрів України від 21.08.2019 № 800. URL : https://zakon.rada.gov.ua/laws/show/800-2019-п\#Text.

60 Стратегія розвитку вищої освіти в Україні на 2021-2031рр. : проект, підготовлений на виконання Указу Президента України «Про вдосконалення вищої освіти в https://mon.gov.ua/storage/app/media/rizne/2020/09/25/rozvitku-vishchoi-osviti-v-ukraini-02-10-2020.pdf.

61 Москаленко В.О. Основні принципи формування кадрового потенціалу підприємства. Бізнес-навігатор. 2010 . № 3 (20). 8 с. С. 3. URL : http://dspace.nuft.edu.ua/jspui/bitstream/123456789/10890/1/Basic\%20principles.pdf.

62 Про освіту : Закон України від 05.09.2017 № 2145-VIII. URL : https://zakon.rada.gov.ua/laws/show/2145-19\#n2093.

63 Burquel N. Training university leaders and manager's - why and how? Leadership and Governance in Higher Education. 2012. Vol. № 1. 15 p. P. 4. URL : https://www.academia.edu/15170512/Training Leaders and Managers in Higher Education.

${ }^{64}$ Losinger I.D. The Development of University Leaders: Supporting the Professional Development Needs of University Presidents. Adult Education and the Contested Terrain of Public Policy: Proceedings of the Annual Conference of the Canadian Association for the Study of Adult Education (21st, Toronto, Ontario May 30-31 and June 1, 2002). 2002. 438 p. P. 374-376. P.375. URL: https://files.eric.ed.gov/fulltext/ED478964.pdf.

${ }^{65}$ Словник іншомовних слів: 23000 слів та термінологічних словосполучень / уклад. Л.О. Пустовіт та ін. К. : Довіра, 2000.1018 с. С. 762. 66 Москаленко В.О. Основні принципи формування кадрового потенціалу підприємства. Бізнес-навігатор. 2010. № 3 (20). 8 с. С. 4-5. URL : http://dspace.nuft.edu.ua/ispui/bitstream/123456789/10890/1/Basic\%20principles.pdf.
} 
- специфічні, що визначають умови формування кадрового потенціалу: оптимізації кадрового потенціалу підприємства, комплементарності управлінських ролей, формування унікального кадрового потенціалу.

У розвитку управлінського персоналу можна виділити періоди: посадова адаптація; підвищення кваліфікації керівників-початківців; професійна діяльність управлінського персоналу, оцінювання результатів діяльності управлінського персоналу; організація підвищення рівня професійної компетентності.

На нашу думку, кожен період розвитку управлінського персоналу базується на певних принципах. До загальних принципів розвитку управлінського персоналу можна віднести 67; 68; 69:

- безперервність процесу професійного розвитку управлінського персоналу;

- систематичне оновлення кадрів;

- демократизм у роботі з кадрами (рівне право бути обраним на посаду);

- додержання інтересів роботодавця та працівника.

Основними принципами посадової адаптації є: системність; повага до людини; відкритість.

До принципів підвищення кваліфікації керівників-початківців можна віднести: «науковість; системність; послідовність; індивідуалізація навчання; цілісність; інтегративність; міждисциплінарність; добровільність і доступність, варіативність; практична спрямованість» ${ }^{70}$.

Принципами професійної діяльності є: взаємоповага та позитивна мотивація ${ }^{71}$; «системна взаємодія із зовнішнім середовищем; відповідальність й саморегулювання; комплексне використання сучасних інформаційних технологій» ${ }^{72}$; звітність й дотримання вимог; максимізація успіху інституції ${ }^{73}$; колегіальність (при доборі й затвердженні персоналу на посадах ${ }^{74}$, співпраця управлінського персоналу із вченою радою та іншими органами, що беруть участь в управлінні відповідно до статутів університетів) ${ }^{75}$.

Принципами оцінювання результатів діяльності управлінського персоналу є: системність; повага до людини; контроль шляхом оцінювання діяльності за досягнутими результатами і методами роботи; рефлексії ${ }^{6 ;} 77$.

\section{Складові розвитку управлінського персоналу}

Розвиток управлінського персоналу залежить від ряду факторів та умовно поділяється на ${ }^{78 ;} 79$ :

- професійно-кваліфікаційний та посадовий розвиток;

- розвиток операційної та мотиваційної сфер;

- розвиток компетентностей (включаючи цінності, якості тощо для якісного та успішного виконання покладених посадових обов'язків);

- корпоративні установки;

- технології інновацій тощо.

\footnotetext{
67 Про професійний розвиток працівників : Закон України від 12.01.2012 № 4312-VI. URL : https://zakon.rada.gov.ua/laws/show/431217\#Text.

68 Малиновський В.Я. Словник термінів і понять з державного управління. Вид. 2-ге, доп. і виправл. К. : Центр сприяння інституційному розвитку державної служби, 2005. 254 с. С. 200.

69 Воронько О. Державна кадрова політика України: ї̈ формування та принципи. Вісник УАДУ. 1999. № 4. С. 60-68. С. 66.

70 Берека В.Є. Теоретичні і методичні основи фахової підготовки магістрів з менеджменту освіти: дис. ... д.пед.н.: спец. 13.00.04 «Теорія і методика професійної освіти». Київ, 2008. 450 с, с. 113-114.

${ }^{71}$ Національна доктрина розвитку освіти, затверджена Указом Президента України від 17.04.2002 № 347/2002. URL: https://zakon.rada.gov.ua/laws/show/347/2002\#Text.

72 Лєбєдєва І.Ю., Томашевская В.О. Підходи до оцінки персоналу як складової аналізу кадрового потенціалу та технології його розвитку. Інвестиції: практика та досвід. 2018. № 12. С. 75-81. С. 76. URL : http://www.investplan.com.ua/pdf/12_2018/16.pdf.

${ }^{73}$ Copland G. Governance in a changing environment: thought-piece. Contemporary issues in governance. June 2014. 26 p. P. 6. URL: https://www.advance-he.ac.uk/knowledge-hub/governance-changing-environment-thought-piece.

74 Воронько О. Державна кадрова політика України: ї̈ формування та принципи. Вісник УАДУ. 1999. № 4. С. 60-68. С. 66.

75 Illustrative Practice Note 3: Academic Governance / Committee of University Chairs. 2017. 8 p. P. $1 . \quad$ URL: https://www.universitychairs.ac.uk/wp-content/uploads/2017/01/CUC-IPN3-Academic-Governance-Jan-17.pdf.

${ }^{76}$ Малиновський В.Я. Словник термінів і понять з державного управління. Вид. 2-ге, доп. і виправл. К. : Центр сприяння інституційному розвитку державної служби, 2005. 254 с. С. 200.

77 Воронько О. Державна кадрова політика України: ї̈ формування та принципи. Вісник УАДУ. 1999. № 4. С. 60-68. С. 67.

78 Петков В.3. Професійний розвиток керівників вищих навчальних закладів як успадкована проблема науки державного управління. Державне управління: удосконалення та розвиток. 2010. № 4. URL : http://www.dy.nayka.com.ua/?op=1\&z=126.

${ }^{79}$ Бобир В.Г. Професійний розвиток керівника дошкільного навчального закладу. Науковий вісник УМО «Педагогіка». 2016. № 2. 9 с. URL : http://umo.edu.ua/images/content/institutes/imp/vydannya/visnyk umo/pedagogika/2 2016/Бобир.pdf.
} 
Особистісні й професійні якості керівника, ступінь усвідомлення ним необхідності професійно розвиватися самому і сприяти розвитку інших багато в чому визначають результативність управління і розвитку установи (організації) ${ }^{80}$.

Розвиток управлінського персоналу університету, на нашу думку, також передбачає розвиток їх потенціалу, а саме управлінського («потенційна здатність управлінського персоналу на засадах професіоналізму оптимально застосувати професійно-кваліфікаційний, творчий потенціали та організаційну спроможність із метою досягнення сталого та ефективного функціонування підприємства» 81; 82) і науковопедагогічного, що можуть бути розвинені під час формальної, неформальної та інформальної освіти для самовдосконалення і саморозвитку.

У структурі потенціалу управлінського персоналу можна виділити такі складові: інтелектуальна (компетентності; пізнавальні і творчі здібності; увага, пам'ять тощо); емоційна (емоції; вольові якості; поведінкові якості); духовна (цінності; ідеали).

Управлінський персонал університету має розвиватися у напрямах: технологічному (врахування у діяльності новітніх управлінських технологій); правовому (знання та дотримання нормативно-правових актів, що регулюють функціонування сфери вищої освіти); організаційно-економічному (ефективне планування «індивідуальної освітньої траєкторії», раціональне використання свого робочого часу, мотивація, моральне і матеріальне стимулювання управлінського персоналу); соціально-психологічному (впровадження у практику діяльності різноманітних соціологічних і психологічних процедур); науково-педагогічному (здобуття наукових ступенів і вчених звань, підвищення кваліфікації управлінського персоналу, внутрішньо-організаційне навчання, самоосвіта й саморозвиток тощо) ${ }^{83}$.

Професійний розвиток управлінського персоналу як процес має включати етапи ${ }^{84}$; ${ }^{85}$ :

1. Проєктування індивідуальної траєкторії професійного розвитку (включає визначення основних компонентів діяльності керівника, визначення напрямів підготовки, створення мотивації).

2. Організація процесу професійного розвитку управлінського персоналу (здійснення неформальної чи інформальної освіти або реалізація програм формальної освіти).

3. Оцінювання стану професійного розвитку управлінського персоналу (критерії оцінки результативності, процедура експертної оцінки діяльності, підрахунок підсумкового результату).

4. Коригування індивідуальної траєкторії професійного розвитку.

\section{Компетентності управлінського персоналу}

Розвиток управлінського персоналу університетів здійснюється відповідно до освітньої парадигми, на якій базується освітня політика країни. У нормативних документах України ${ }^{86}$ такою парадигмою визначено компетентнісну парадигму, згідно з якою формування компетентностей має бути як результат освіти; побудова навчальних планів і програм за модулями знань, необхідних для визначених стандартами компетентностей; багатокритеріальне оцінювання засвоєних знань та набутих компетентностей, проектування стратегії дій, вибір альтернатив тощо ${ }^{87}$. У свою чергу, «модернізація управління освітою передбачає підвищення компетентності управлінців усіх рівнів» 88.

\footnotetext{
${ }^{80}$ Сидорук Є. Ефективність управління персоналом сучасної організації та характеристика факторів, що ії обумовлюють / Науковий блог. Національний університет «Острозька академія» 2012. URL : https://naub.oa.edu.ua/2012/efektyvnist-upravlinnya-personalomsuchasnoji-orhanizatsiji-ta-harakterystyka-faktoriv-scho-jiji-obumovlyuyut/

81 Петрович Й.М., Прокопишин-Рашкевич Л.М. Економіка і фінанси підприємств : підручник. Львів : Вид-во «Магнолія - 2006», 2014 408 c. URL: https://pidruchniki.com/1924070164701/ekonomika/rol_mistse_upravlinskogo_potentsialu_zabezpechenni_rozvitku_pidpriyemstva.

82 Сіменко І.В., Романюк М.К. Сутність і основні складові управлінського потенціалу суб'єкта господарювання. Актуальні проблеми економіки. 2012. № 8 (134). С. 209-218. C. 213. URL : http://nbuv.gov.ua/UJRN/ape_2012_8_27.

83 Гончарук Н.Т. Управління керівним персоналом у сфері державної служби України: теорія та практика : монографія. Д. : ДРІДУ НАДУ, 2012. 343 с. С. $30-31$.

84 Братищенко I. Складові успішного професійного розвитку сучасного вчителя / Slideshare. URL https://www.slideshare.net/ssuser15e5ff/ss-94969247.

85 Жиленко М. Оцінка ефективності управлінської діяльності керівника закладу вищої освіти. Вісник Київського національного університету імені Тараса Шевченка. Сер.: Педагогіка. $2018 . \quad$ № 1 (7). C. 11-14. C. $14 . \quad$ URL: http://pedvisnyk.knu.ua/index.php/pedvisnyk/article/view/43/41.

86 Національна стратегія розвитку освіти в Україні на період до 2021 року, схвалена Указом Президента України від 25.06.2013 № 344/2013. URL : http://zakon0.rada.gov.ua/laws/show/344/2013.

87 Петков В.3. Професійний розвиток керівників вищих навчальних закладів як успадкована проблема науки державного управління. Державне управління: удосконалення та розвиток. 2010. № 4. URL : http://www.dy.nayka.com.ua/?op=1\&z=126.

88 Національна доктрина розвитку освіти, затверджена Указом Президента України від 17.04.2002 № 347/2002. URL:
} 
На основі аналізу джерел можемо визначити, що окрім універсальних компетентностей (soft skills) («спілкування рідною мовою; спілкування іноземними мовами; математична компетентність та базові компетентності в науці і технологіях; цифрові компетентності; уміння вчитися; соціальні та громадянські компетентності; навички ініціативи та підприємництва; культурна самосвідомість і самовираження» ${ }^{89}$ ), управлінському персоналу університету мають бути притаманні групи компетентностей:

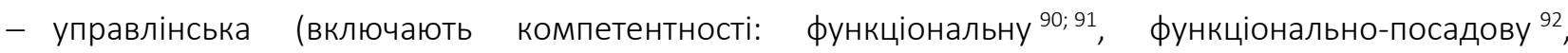
соціальну ${ }^{93}$, професійну ${ }^{94}$ ) - «здатність забезпечувати безперервний професійний розвиток колективу, організації, шляхом прийняття (в межах своїх функціональних обов'язків і повноважень) управлінських рішень, що сприяють досягненню встановленої мети» 95; на основі певного мінімуму знань та навичок, «що повинні входити до складу базового інтелектуального комплексу: знання з права, економіки, адміністрування, фінансів, кадрового менеджменту, екології, соціальних і гуманітарних наук; уміння ... відбирати, аналізувати та узагальнювати інформацію; володіння аналітичним мисленням, розумінням сучасних проблем менеджменту, технологією адміністративної роботи, здатністю продукувати нові ідеї, приймати управлінські рішення» тощо ${ }^{96}$,

- інноваційно-інтелектуальна (включає інтелектуальну ${ }^{97 ; 98}$ компетентнсіть) - здатність до інноваційного мислення, прийняття нестандартних, але ефективних рішень та вміння розвивати творчі здібності колективу, щоб отримати унікальні інноваційні ідеї та матеріалізувати їх у діяльності ${ }^{99}$;

- соціально-психологічна (соціально-психологічну ${ }^{100 ; 101}$, соціальну ${ }^{102}$ ) - здатність «працювати в команді, співпрацювати, вирішувати конфлікти» ${ }^{103}$, «підтримувати зв'язки, впливати, досягати своєї цілі,

https://zakon.rada.gov.ua/laws/show/347/2002\#Text.

89 Які 8 компетентностей є ключовими з точки зору Європейської Комісії в галузі освіти? / Вінницький національний технічний університет. URL: http://ininv.vntu.edu.ua/ukr/index.php?option=com_content\&view=article\&id=58:23-05-17-news-keycompetences\&catid=37\&ltemid=857.

90 Управління персоналом (2003). URL : https://library.if.ua/book/45/3054.html.

91 Лисенко Ю.В. Ефективність використання управлінського персоналу машинобудівних підприємств : автореф. дис... канд. екон. наук: 08.00.04; Класич. приват. ун-т. Запоріжжя, 2008. 20 c. C. $13 . \quad$ UTL: http://irbis-nbuv.gov.ua/cgibin/irbis nbuv/cgiirbis 64.exe?Z21ID=\&I21DBN=ARD\&P21DBN=ARD\&S21STN=1\&S21REF=10\&S21FMT=fullwebr\&C21COM=S\&S21CNR=20\& S21P01=0\&S21P02=0\&S21P03=A=\&S21COLORTERMS=1\&S21STR=Лисенко Ю.В.\$.

92 Адамович I.В. Розвиток інформаційної компетентності керівників загальноосвітніх навчальних закладів в післядипломній педагогічній освіті : автореф. дис. ... канд. пед. наук : 13.00.04; Терноп. нац. пед. ун-т ім. Володимира Гнатюка. Тернопіль, 2015.20 с. C. 10. URL : http://dspace.tnpu.edu.ua/bitstream/123456789/5570/1/Adamovu4.pdf.

93 Красильник Ю.С. Розвиток управлінської компетентності керівника професійного навчального закладу в процесі підвищення кваліфікації. Професійний розвиток та управління людськими ресурсами в системі післядипломної педагогічної освіти в контексті трансформації освіти України : зб. матер. Всеукр. наук.-практ. конф., Київ, 28.10.2016. К. : УМО НАПН України, 2016. С. 380-384. С. 382. URL : http://umo.edu.ua/images/content/institutes/cipo/kaf_derg_slug/material_diyaln/MАТЕРІАЛИ_КОНФЕРЕНЦії_28.10.16_23.01.17.pdf. 94 Петрович Й.М., Прокопишин-Рашкевич Л.М. Економіка і фінанси підприємств : підручник. Львів : Вид-во «Магнолія - 2006», 2014. 408 с. URL: https://pidruchniki.com/1924070164701/ekonomika/rol mistse upravlinskogo potentsialu zabezpechenni rozvitku pidpriyemstva.

95 Державне управління у сфері освіти : глосарій з дисциплін магістерської програми за спеціальністю «Державне управління в сфері освіти» / авт. кол. К. : НАДУ, 2013. 48 с. С. 33.

96 Малиновський В.Я. Словник термінів і понять з державного управління. Вид. 2-ге, доп. і виправл. К. : Центр сприяння інституційному розвитку державної служби, 2005. 254 с. С. 201.

97 Управління персоналом (2003). URL : https://library.if.ua/book/45/3054.html.

98 Лисенко Ю.В. Ефективність використання управлінського персоналу машинобудівних підприємств : автореф. дис... канд. екон. наук: 08.00.04; Класич. приват. ун-т. Запоріжжя, 2008. 20 с. C. $13 . \quad$ UTL: http://irbis-nbuv.gov.ua/cgibin/irbis nbuv/cgiirbis 64.exe?Z21ID=\&I21DBN=ARD\&P21DBN=ARD\&S21STN=1\&S21REF=10\&S21FMT=fullwebr\&C21COM=S\&S21CNR=20\& S21P01=0\&S21P02=0\&S21P03=A=\&S21COLORTERMS=1\&S21STR=Лисенко Ю.В.\$.

99 Петрович Й.М., Прокопишин-Рашкевич Л.М. Економіка і фінанси підприємств : підручник. Львів : Вид-во «Магнолія - 2006», 2014.408 с. URL : https://pidruchniki.com/1924070164701/ekonomika/rol_mistse_upravlinskogo_potentsialu_zabezpechenni_rozvitku_pidpriyemstva.

100 Лисенко Ю.В. Ефективність використання управлінського персоналу машинобудівних підприємств : автореф. дис... канд. екон. наук: 08.00 .04 ; Класич. приват. ун-т. Запоріжжя, 2008. 20 c. C. $13 . \quad$ UTL: http://irbis-nbuv.gov.ua/cgibin/irbis nbuv/cgiirbis 64.exe?Z21ID=\&I21DBN=ARD\&P21DBN=ARD\&S21STN=1\&S21REF=10\&S21FMT=fullwebr\&C21COM=S\&S21CNR=20\&S21P01 $=0 \& S 21 P 02=0 \& S 21 P 03=A=\& S 21 C O L O R T E R M S=1 \& S 21 S T R=$ Лисенко Ю.В.S.

101 Петрович Й.М., Прокопишин-Рашкевич Л.М. Економіка і фінанси підприємств : підручник. Львів : Вид-во «Магнолія - 2006», 2014.408 с. URL : https://pidruchniki.com/1924070164701/ekonomika/rol_mistse_upravlinskogo_potentsialu_zabezpechenni_rozvitku_pidpriyemstva.

102 Красильник Ю.С. Розвиток управлінської компетентності керівника професійного навчального закладу в процесі підвищення кваліфікації. Професійний розвиток та управління людськими ресурсами в системі післядипломної педагогічної освіти в контексті трансформачії освіти України : зб. матер. Всеукр. наук.-практ. конф., Київ, 28.10.2016. К. : УМО НАПН України, 2016. С. 380-384. С. 382. URL : http://umo.edu.ua/images/content/institutes/cipo/kaf derg slug/material diyaln/MАТЕРІАЛИ КОНФЕРЕНЦІї 28.10.16 23.01.17.pdf. 103 Петрович Й.М., Прокопишин-Рашкевич Л.М. Економіка і фінанси підприємств : підручник. Львів : Вид-во «Магнолія - $2006 », 2014.408$ с. URL : https://pidruchniki.com/1924070164701/ekonomika/rol mistse upravlinskogo potentsialu zabezpechenni rozvitku pidpriyemstva. 
правильно сприймати і передавати чужі погляди» ${ }^{104}$ ), комунікувати в системі управління. Даний вид компетентності також може бути представлений системою мотивів професійної діяльності, емоційновольовими характеристиками, поведінковими реакціями, системою навичок ефективної самоорганізації управлінської діяльності, емпатією, рефлексією тощо» 105 ;

- аналітико-діагностична (включає загальнонаукову ${ }^{106}$ компетентність) - «здатність практично застосовувати методи наукового дослідження (зокрема системного аналізу й синтезу), технологій діагностування, здійснювати інтерпретацію отриманих результатів» ${ }^{107}$;

- професійно-педагогічна ${ }^{108}$ - «здатність застосовувати основи педагогіки та психології в освітньому процесі в закладах вищої освіти» ${ }^{109}$;

- інформаційно-комунікаційна - «здатність практично застосовувати інформаційно-комунікаційні технології для задоволення професійних потреб і розв'язання суспільно важливих управлінських завдань» ${ }^{110}$.

Таким чином, в управлінського персоналу університету окрім універсальних компетентностей (soft skills) повинні бути такі компетентності: управлінська, інноваційно-інтелектуальна, соціально-психологічна, аналітико-діагностична, професійно-педагогічна, інформаційно-комунікаційна.

\section{Оцінювання управлінського персоналу}

Оцінювання управлінського персоналу та його діяльності має одне із визначальних значень для університету, адже від оптимальності його формування та подальшого професійного розвитку залежить ефективність функціонування самого університету. Управлінський персонал різних рівнів управляє основними процесами (організаційними, фінансовими тощо) університету, тому оцінювати управлінський персонал потрібно за чітко обґрунтованими критеріями з урахуванням особливостей професійної діяльності. При оцінюванні управлінського персоналу ЗВО слід використовувати прийоми, такі як: системний аналіз, абстрактна логіка, спостереження, індукція та дедукція, експертні та статистичні методи тощо ${ }^{111}$.

Оцінити результативність праці управлінського персоналу можна за напрямами ${ }^{112:}$

- оцінювання результативності праці самого керівника (відповідності результатів виконаних завдань поставленим вимогам);

- оцінювання результативності праці структурної одиниці, якою управляє керівник (правильно спланована, організована та вчасно виконана робота у підрозділі (відділі тощо).

Це дозволить оцінити як реальний рівень результативності діяльності керівника, так і з'ясувати необхідні напрями у його навчанні для оптимізації управління університетом (підрозділом) ${ }^{113}$.

Практика оцінювання керівників має включати: оцінювання минулих результатів діяльності як ключового джерела інформації про здатність керівників спричинити зміни у майбутньому; критерії, що

\footnotetext{
104 Управління персоналом (2003). URL : https://library.if.ua/book/45/3054.html.

105 Державне управління у сфері освіти : глосарій з дисциплін магістерської програми за спеціальністю «Державне управління в сфері освіти» / авт. кол. К. : НАДУ, 2013. 48 с. с. 33.

106 Красильник Ю.С. Розвиток управлінської компетентності керівника професійного навчального закладу в процесі підвищення кваліфікації. Професійний розвиток та управління людськими ресурсами в системі післядипломної педагогічної освіти в контекст трансформації освіти України : зб. матер. Всеукр. наук.-практ. конф., Київ, 28.10.2016. К. : УМО НАПН України, 2016. С. 380-384. С. 382. URL : http://umo.edu.ua/images/content/institutes/cipo/kaf_derg_slug/material_diyaln/MATEPIAЛИ_КОНФЕРЕНЦIї_28.10.16_23.01.17.pdf. 107 Державне управління у сфері освіти : глосарій з дисциплін магістерської програми за спеціальністю «Державне управління в сфері освіти» / авт. кол. К. : НАДУ, 2013. 48 с. с. 32.

108 Красильник Ю.С. Розвиток управлінської компетентності керівника професійного навчального закладу в процесі підвищення кваліфікації. Професійний розвиток та управління людськими ресурсами в системі післядипломної педагогічної освіти в контексті трансформації освіти України : зб. матер. Всеукр. наук.-практ. конф., Київ, 28.10.2016. К. : УМО НАПН України, 2016. С. 380-384. С. 382. URL : http://umo.edu.ua/images/content/institutes/cipo/kaf_derg_slug/material_diyaln/MATEPIAЛИ_КОНФЕРЕНЦIї_28.10.16_23.01.17.pdf. 109 Стандарт вищої освіти за спеціальністю 281 «Публічне управління та адміністрування» для другого (магістерського) рівня вищої освіти, затверджений наказом МOH України від 04.08.2020. № 1001. URL: https://mon.gov.ua/storage/app/media/vishchaosvita/zatverdzeni standarty/2020/08/05/281publichne-upravlinnya-ta-administruvannya-magistr.pdf.

110 Державне управління у сфері освіти : глосарій з дисциплін магістерської програми за спеціальністю «Державне управління в сфері освіти» / авт. кол. К. : НАДУ, 2013. 48 с. С. 33

111 Пирожак Є.К., Скриньковський Р.М. Сучасні підходи до оцінювання управлінського персоналу підприємства. Науковий вісник НлтУ України. 2014. Вип. 24.10. С. 306-311. С. 308. URL : http://nbuv.gov.ua/UJRN/nvnltu_2014_24.10 53.

112 Пирожак Є.К., Скриньковський Р.М. Сучасні підходи до оцінювання управлінського персоналу підприємства. Науковий вісник НЛтУ України. 2014. Вип. 24.10. С. 306-311. С. 308. URL : http://nbuv.gov.ua/UJRN/nvnltu 201424.1053.

113 Жиленко М. Оцінка ефективності управлінської діяльності керівника закладу вищої освіти. Вісник Київського національного університету імені Тараса Шевченка. Сер.: Педагогіка. 2018. № 1 (7). C.11-14. C. $11 . \quad$ URL:
} http://pedvisnyk.knu.ua/index.php/pedvisnyk/article/view/43/41. 
сприяють формуванню позитивних змін в академічній обстановці, а не лише традиційні риси лідерства; співвіднесення оцінювання із програми розвитку керівника, що допоможе йому виконувати роботу, що відрізняється від виконаної чотири-п'ять років раніше роботи ${ }^{114}$.

Оцінювання проводиться на таких етапах роботи ${ }^{115}$ :

- відбір кандидата на вакантну посаду - для встановлення відповідності компетентностей і особистісних якостей посадовим вимогам і корпоративній культурі організації;

- проходження випробування (випробувального терміну) - для додаткової оцінки рівня відповідності співробітника займаній посаді і рівня його адаптації в організації;

- виконання поточної діяльності - для уточнення плану професійного і кар'єрного зростання співробітни ка, прийняття рішень про преміювання, перегляд заробітної плати;

- навчання співробітника (відповідно до цілей організації) - для визначення поточних знань співробітника і потреби в його навчанні (бажаною є така процедура і після проходження навчання);

- формування кадрового резерву - для оцінки професійного і в першу чергу особистісного потенціалу співробітника;

- звільнення - для виявлення некомпетентності співробітника, причому підставою звільнення в цьому разі можуть служити тільки результати атестації.

Оцінювання особистісно-професійних характеристик управлінця можна здійснювати за критеріями та показниками, зокрема 116; 117 :

- організаційні (лідерські якості, здатність до керівництва, організованість, дисциплінованість та самоконтроль, впорядкованість дій, інформаційні зв'язки та контакти, ініціативність, цілеспрямованість тощо);

- професійно-ділові (стаж роботи, професійні знання, здатність до глибокого аналізу ситуації, що склалася, готовність до ризику, відповідальність, стратегічне мислення, наполегливість, вміння приймати оптимальні управлінські рішення (здатність адекватно реагувати на ситуацію, що склалася, та вживати ефективних заходів для ії вирішення) самостійність; дисципліна; ініціативність; співпраця тощо);

- діяльнісні (кількість роботи (порівняння запланованого обсягу роботи і досягнутого рівня); якість роботи (ступінь виконання робіт якісним стандартам); терміни виконання роботи);

- особистісні (працездатність; цілеспрямованість; послідовність у досягненні поставлених цілей; лідерські якості; організаційні здібності; управлінський потенціал; стресостійкість; комунікаційні властивості і навички тощо).

Головним умовами, що визначають ступінь досягнення цілей управління $\epsilon$ професіоналізм, організованість, порядність керівника, що можна оцінити за критеріями професіоналізації ${ }^{118}$ :

- об'єктивні, що свідчать про ступінь відповідності особистості вимогам діяльності - продуктивність, якість, надійність;

- суб'єктивні, що дозволяють оцінювати ступінь відповідності діяльності вимогам особистості самооцінка, рефлексія, мотивація, амбіції.

При оцінюванні необхідно професійно значущі якості управлінського персоналу групувати відповідно до виконуваних функцій. Разом із тим, управлінці різних рівнів будуть оцінюватися за відповідними критеріями, наприклад: орієнтація на ринку освітніх послуг; стан діловодства; організація взаємодії адміністрації, персоналу, студентів; стан інноваційної, професійно-педагогічної і підприємницької діяльності; якість освітнього процесу; рівень професійної підготовки випускників; ефективність фінансово-господарської діяльності університету; стан матеріально-технічного і навчально-методичного забезпечення університету; стан психологічного клімату в колективі; задоволеність персоналу методами і стилем управління;

\footnotetext{
${ }^{114}$ How Presidential Evaluations Must Change / Association of Governing Boards of Universities and Colleges. 2012. Vol. 20. Numb. 1. URL : https://agb.org/trusteeship-article/how-presidential-evaluations-must-change/

115 Лєбєдєва І.Ю., Томашевская В.О. Підходи до оцінки персоналу як складової аналізу кадрового потенціалу та технології його розвитку. Інвестиції: практика та досвід. 2018. № 12. С. 75-81. С. 78-79. URL : http://www.investplan.com.ua/pdf/12 2018/16.pdf.

116 Лєбєдєва І.Ю., Томашевская В.О. Підходи до оцінки персоналу як складової аналізу кадрового потенціалу та технології його розвитку. Інвестиції: практика та досвід. 2018. № 12. С. 75-81. С. 80. URL : http://www.investplan.com.ua/pdf/12 2018/16.pdf.

117 Пирожак Є.К., Скриньковський Р.М. Сучасні підходи до оцінювання управлінського персоналу підприємства. Науковий вісник Нлту України. 2014. Вип. 24.10. С. 306-311. С. 309. URL : http://nbuv.gov.ua/UJRN/nvnltu 201424.1053.

118 Жиленко М. Оцінка ефективності управлінської діяльності керівника закладу вищої освіти. Вісник Київського національного університету імені Тараса Шевченка. Сер.: Педагогіка. 2018. № 1 (7). C. 11-14. C. 12. URL:
} http://pedvisnyk.knu.ua/index.php/pedvisnyk/article/view/43/41. 
стимулювання професійного зростання і підвищення кваліфікації персоналу; мотивування виконавської і трудової дисципліни, відповідальності і професійно-педагогічної ініціативи; санітарно-гігієнічні умови і стан техніки безпеки в університеті; правове й інформаційне забезпечення професійної діяльності персоналу; своєчасність контролю, оцінки і корекції освітньо-виховного процесу; контроль досягнення освітніх стандартів; відданість університету ${ }^{119}$.

Нині однією із методик оцінювання керівників $є$ 360-градусна модель кожні три-чотири роки, що базується на 20-50 конфіденційних інтерв'ю з людьми, котрі можуть коментувати результати діяльності виконавчої влади ${ }^{120}$.

Оцінювання, як правило, охоплює ${ }^{121}$ :

- здатність керівника використовувати соціальний інтелект, щоб створити позитивні зміни (наявність «м'яких» навичок спілкування: виявляє емпатію, створює згуртовані команди та сприяє різноманіттю);

- порівняння поточної тактики з майбутніми потребами (чи залишається керівник уважним до найбільш критичних викликів, що вимагають лідерства (у досягненні стратегічних цілей установи), на відміну від досягнення стандартних, звичних чи цілком доступних цілей;

- поведінку в ключових сферах посадової інструкції керівника, де очікується, що керівники матимуть добрі результати: збільшення фінансової та репутаційної сили установи, провідні вчені, залучення грошей, управління внутрішніми та зовнішніми відносинами тощо.

Сьогодні також наголос робиться на використанні механізмів моніторингу результативності, за допомогою ключових показників (KPI), що стосуються освіти, досвіду студентів, досліджень та обміну знаннями, стану академічної якості, і включаючи: склад здобувачів вищої освіти; докази академічної відмінності; внесок до розвитку академічного середовища; інтеграцію академічного та стратегічного планування. У багатьох зарубіжних університетах звіти про такі ключові показники представляються керівним органам за допомогою таких пристроїв, як збалансована карта показників або система маркерів для моніторингу прогресу ${ }^{122}$. В Україні також запроваджується оцінювання діяльності ректорів університетів через включення до їх контрактів цільових показників діяльності університету ${ }^{123 ;}{ }^{124}$.

119 Жиленко М. Оцінка ефективності управлінської діяльності керівника закладу вищої освіти. Вісник Київського національного університету імені Тараса Шевченка. Сер.: Педагогіка. $2018 . \quad$ № 1 (7). C. 11-14. C. $13 . \quad$ URL: http://pedvisnyk.knu.ua/index.php/pedvisnyk/article/view/43/41.

120 How Presidential Evaluations Must Change / Association of Governing Boards of Universities and Colleges. 2012. Vol. 20. Numb. 1. URL : https://agb.org/trusteeship-article/how-presidential-evaluations-must-change/

121 How Presidential Evaluations Must Change / Association of Governing Boards of Universities and Colleges. 2012. Vol. 20. Numb. 1. URL : https://agb.org/trusteeship-article/how-presidential-evaluations-must-change/

122 Illustrative Practice Note 3:Academic Governance / Committee of University Chairs. 2017. 8 p. P.6. URL: https://www.universitychairs.ac.uk/wp-content/uploads/2017/01/CUC-IPN3-Academic-Governance-Jan-17.pdf.

123 Про вищу освіту : Закон України від 01.07.2014 № 1556-VII. URL : https://zakon.rada.gov.ua/laws/show/1556-18\#Text.

124 Стратегія розвитку вищої освіти в Україні на 2021-2031рр. : проект, підготовлений на виконання Указу Президента України «Про вдосконалення вищої освіти в Україні» від 03.06 .2020 № 210/2020. 71 с. URL: 


\section{Висновки}

1. В Україні на даний час відсутнє нормативне регулювання питання організації процесу підвищення кваліфікації (стажування) управлінського персоналу університету (окрім управлінського персоналу, вперше призначеного на посаду).

2. Наше наукове дослідження базується на таких основних поняттях: управлінський персонал категорія осіб, які працюють в установі, наділених повноваженнями виконувати управлінські функції й відповідальністю за результативність роботи підлеглих та керованих ними структур; управлінський персонал університету - категорія працівників університету, які мають визначені якісні характеристики, наділені повноваженнями виконувати управлінські функції й відповідальністю за результативність роботи підлеглих та керованих ними структур; розвиток управлінського персоналу університету - безперервна, цілеспрямована реалізація потенціалу управлінського персоналу університету через оновлення, розвиток й удосконалення компетентностей, збагачення досвіду, шляхом неперервної професійної освіти (вища освіта, післядипломна освіта, підвищення кваліфікації тощо), самоосвіти та професійної діяльності відповідно до цілей і завдань діяльності університету.

3. Основними принципами розвитку управлінського персоналу є: безперервність; демократизм; додержання інтересів роботодавця та працівника; системність; повага до людини; відкритість; відповідальність й саморегулювання; науковість; індивідуалізація навчання; цілісність; добровільність і доступність, варіативність; практична спрямованість.

4. Розвиток управлінського персоналу університету передбачає розвиток науково-педагогічного потенціалу та має включає етапи, зокрема: проєктування індивідуальної траєкторії професійного розвитку, організацію процесу, оцінювання стану професійного розвитку та коригування індивідуальної траєкторії.

5. Успішно вирішувати поставлені завдання управлінський персонал університету зможе за умови наявності відповідних компетентностей перелік яких не є вичерпним (базовий перелік компетентностей, що міститися у вимогах до кандидата при відборі на посаду, буде доповнюватися й розширюватися під час формальної, неформальної й інформальної освіти, практичної діяльності). Окрім універсальних компетентностей (soft skills) в управлінського персоналу повинні бути розвинені такі групи компетентностей: управлінська, інноваційно-інтелектуальна, соціально-психологічна, аналітико-діагностична, професійнопедагогічна, інформаційно-комунікаційна.

6. Оцінювання управлінського персоналу реалізується через оцінювання результативності праці керівника та структурної одиниці, якою він управляє. Основними критеріями і показниками для оцінювання управлінського персоналу $є$ : організаційні (лідерські якості, здатність до керівництва, організованість, дисциплінованість та самоконтроль, впорядкованість дій, інформаційні зв'язки та контакти, ініціативність, цілеспрямованість тощо); професійно-ділові (стаж роботи, професійні знання, здатність до глибокого аналізу ситуації, що склалася, готовність до ризику, відповідальність, стратегічне мислення, наполегливість, вміння приймати оптимальні управлінські рішення (здатність адекватно реагувати на ситуацію, що склалася, та вживати ефективних заходів для їі вирішення) самостійність; дисципліна; ініціативність; співпраця тощо); діяльнісні (кількість роботи (порівняння запланованого обсягу роботи і досягнутого рівня); якість роботи (ступінь виконання робіт якісним стандартам); терміни виконання роботи); особистісні (працездатність; цілеспрямованість; послідовність у досягненні поставлених цілей; лідерські якості; організаційні здібності; управлінський потенціал; стресостійкість; комунікаційні властивості і навички тощо). 


\section{Список використаних джерел}

1. Адамович І.В. Розвиток інформаційної компетентності керівників загальноосвітніх навчальних закладів в післядипломній педагогічній освіті : автореф. дис. ... канд. пед. наук : 13.00 .04 ; Терноп. нац. пед. ун-т ім. Володимира Гнатюка. Тернопіль, 2015. 20 c. URL : http://dspace.tnpu.edu.ua/bitstream/123456789/5570/1/Adamovu4.pdf.

2. Берека В.Є. Теоретичні і методичні основи фахової підготовки магістрів з менеджменту освіти: дис. ... д.пед.н.: спец. 13.00.04 «Теорія і методика професійної освіти». Київ, 2008. 450 с.

3. Бєлова Л. Підготовка управлінських кадрів для національної освітньої системи. Новий Колегіум. 2016. С. 2729. URL: http://nbuv.gov.ua/UJRN/NovKol 201628.

4. Бобир В.Г. Професійний розвиток керівника дошкільного навчального закладу. Науковий вісник Умо «Педагогіка». 2016. № 2. 9 с. URL : http://umo.edu.ua/images/content/institutes/imp/vydannya/visnyk umo/pedagogika/ 2 2016/Бобир.pdf.

5. Братищенко І. Складові успішного професійного розвитку сучасного вчителя / Slideshare. URL: https://www.slideshare.net/ssuser15e5ff/ss-94969247.

6. Воронько О. Державна кадрова політика України: її формування та принципи. Вісник УАДУ. 1999. № 4. С. 60-68.

7. Гончарук Н.Т. Управління керівним персоналом у сфері державної служби України: теорія та практика : монографія. Д. : ДРІДУ НАДУ, 2012. 343 с.

8. Грушева А.А., Пілевич О.А. Формування управлінської компетентності майбутніх економістів у культурноосвітньому середовищі вищого навчального закладу. Оновлення змісту, форм та методів навчання і виховання в закладах освіти. 2017. Вип. 16. С. 203-207. URL : http://nbuv.gov.ua/UJRN/Ozfm 20171663.

9. Гуменний О.Д. Розвиток інформаційної культури керівників вищих навчальних закладів : монографія. Київ : Міленіум, 2015. 245 с. URL : https://lib.iitta.gov.ua/11259/1/монографія $03 \quad 1115 \quad 1$ hruden.pdf.

10. Гусаров О.О. Особливості розвитку управлінського персоналу в ієрархічних організаційних системах. Економіка та суспільство. 2017. № 8. C. 236-239. URL : http://www.economyandsociety.in.ua/journal/8 ukr/41.pdf.

11. Державне управління у сфері освіти : глосарій з дисциплін магістерської програми за спеціальністю «Державне управління в сфері освіти» / авт. кол. К. : НАДУ, 2013. 48 с.

12. Дяків О.П., Островерхов В.М. Управління персоналом : навч.-метод. посіб. (вид. друге, переробл. і доповнено). Тернопіль : ТНЕУ, 2018. 288 с. URL : http://dspace.wunu.edu.ua/bitstream/316497/33638/1/Посібник 2018 УПверстка 1 (1).pdf.

13. Єльникова Г.В. Компетентнісний підхід до моделювання професійної діяльності керівника вищого навчального закладу. Теорія та методика управління освітою. 2010 . № $4 . \quad$ URL: http://tme.umo.edu.ua/docs/4/10elneel.pdf.

14. Жабенко О. Професійний розвиток науково-педагогічних працівників університетів в умовах інтеграції вищої освіти і науки: моделі і технологія. Теоретичні основи і технологія професійного розвитку науково-педагогічних працівників університетів в умовах інтеграції вищої освіти і науки : монографія / авт. кол. К. : Інститут вищої освіти НАПН України, 2019. 236 с. С. 40-83. URL: https://ihed.org.ua/wp-content/uploads/2020/04/Tehnologiya prof rozvitku pracivn_VNZ_Monogr_IVO-2019-236p_avtors-kolektiv.pdf.

15. Жиленко М. Оцінка ефективності управлінської діяльності керівника закладу вищої освіти. Вісник Київського національного університету імені Тараса Шевченка. Сер.: Педагогіка. $2018 . \quad$ № 1 (7). C. 11-14. URL: http://pedvisnyk.knu.ua/index.php/pedvisnyk/article/view/43/41.

16. Згалат-Лозинська Л.О. Методи оцінки ефективності розвитку управлінського персоналу підприємства. Ефективна економіка. 2017. № 12. URL : http://www.economy.nayka.com.ua/?op=1\&z=6813.

17. Кадри управління. Класифікація та характеристика. URL : https://studfile.net/preview/5043643/

18. Калашнікова С.А. Теоретико-методологічні засади професійної підготовки управлінців-лідерів в умовах сучасних суспільних трансформацій : дис. ... д-ра пед. наук : 13.00 .06 ; ДВНЗ «Ун-т менедж. освіти» НАПН України. К., 2011. 462 c. URL : https://lib.iitta.gov.ua/8664/1/2011 CK_докторська дисератція.pdf.

19. Красильник Ю.С. Розвиток управлінської компетентності керівника професійного навчального закладу в процесі підвищення кваліфікації. Професійний розвиток та управління людськими ресурсами в системі післядипломної педагогічної освіти в контексті трансформації освіти України : зб. матер. Всеукр. наук.-практ. конф., Київ, 28.10.2016. К. : УМО НАПН України, 2016. С. 380-384. URL: http://umo.edu.ua/images/content/institutes/cipo/kaf_derg_slug/material_diyaln/ МАТЕРІАЛИ КОНФЕРЕНЦІї 28.10.16 23.01.17.pdf.

20. Лєбєдєва І.Ю., Томашевская В.О. Підходи до оцінки персоналу як складової аналізу кадрового потенціалу та технології його розвитку. Інвестиції: практика ma досвід. $2018 . \quad$ № $12 . \quad$ C. 75-81. URL : http://www.investplan.com.ua/pdf/12 2018/16.pdf.

21. Лисенко Ю.В. Ефективність використання управлінського персоналу машинобудівних підприємств : автореф. дис... канд. екон. наук: 08.00.04; Класич. приват. ун-т. Запоріжжя, 2008. 20 c. UTL: http://irbis-nbuv.gov.ua/cgibin/irbis nbuv/cgiirbis 64.exe?Z21ID=\&I21DBN=ARD\&P21DBN=ARD\&S21STN=1\&S21REF=10\&S21FMT=fullwebr\&C21COM=S\&

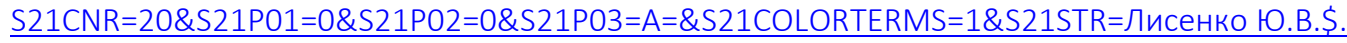

22. Малиновський В.Я. Словник термінів і понять з державного управління. Вид. 2-ге, доп. і виправл. К. : Центр 
сприяння інституційному розвитку державної служби, 2005. 254 с.

23. Міщенко І.А. Значення категорії «управлінські кадри» та становлення наукового змісту їх діяльності». Ефективна економіка. 2014. № 10. URL : http://www.economy.nayka.com.ua/?op=1\&z=3434.

24. Морозова М.Е. Особливості управління персоналом у вищому навчальному закладі. Теорія та методика управління освітою. 2015. № 1 (15). URL : http://nbuv.gov.ua/UJRN/ttmuo 2015120.

25. Москаленко В.О. Основні принципи формування кадрового потенціалу підприємства. Бізнес-навігатор. 2010. № 3 (20). 8 c. URL : http://dspace.nuft.edu.ua/jspui/bitstream/123456789/10890/1/Basic\%20principles.pdf.

26. Національна доктрина розвитку освіти, затверджена Указом Президента України від 17.04 .2002 № 347/2002. URL : https://zakon.rada.gov.ua/laws/show/347/2002\#Text.

27. Національна стратегія розвитку освіти в Україні на період до 2021 року, схвалена Указом Президента України від 25.06.2013 № 344/2013. URL : https://zakon.rada.gov.ua/laws/show/344/2013\#Text.

28. Національний класифікатор України: «Класифікатор професій» ДК 003:2010. К. : Вид-во «Соцінформ», 2010. URL : https://dovidnyk.in.ua/directories/profesii/id/

29. Національний класифікатор України: Класифікатор професій ДК 003:210, затверджений наказом Держспоживстандарту України від 28.07.2010 № 327 (редакція від 15.02.2019). URL: https://zakon.rada.gov.ua/rada/show/va327609-10\#Text.

30. Новий тлумачний словник української мови : у 4 т. / В. Яременко, О. Сліпушко. К. : Вид-во «Аконіт», 2000. T. 2.911 c. С. 240.

31. Педагогічнй менеджмент: данина моді чи потреба часу? URL: https://m.pidru4niki.com/12991010/pedagogika/pedagogichniy menedzhment danina modi potreba chasu.

32. Перелік посад педагогічних та науково-педагогічних працівників, затверджений постановою Кабінету Міністрів України від 14.06.2000 № 963. URL : https://zakon.rada.gov.ua/laws/show/963-2000-п\#Text.

33. Петков В.3. Професійний розвиток керівників вищих навчальних закладів як успадкована проблема науки державного управління. Державне управління: удосконалення та розвиток. 2010 . № 4. URL: http://www.dy.nayka.com.ua/?op=1\&z=126.

34. Петрович Й.М., Прокопишин-Рашкевич Л.М. Економіка і фінанси підприємств : підручник. Львів : Вид-во «Магнолія - 2006», 2014. 408 c. URL: https://pidruchniki.com/1924070164701/ekonomika/ rol mistse upravlinskogo potentsialu zabezpechenni rozvitku pidpriyemstva.

35. Пирожак Є.К., Скриньковський Р.М. Сучасні підходи до оцінювання управлінського персоналу підприємства. Науковий вісник НЛтУ України. 2014. Вип. 24.10. С. 306-311. URL : http://nbuv.gov.ua/UJRN/nvnltu 201424.1053.

36. Положення (стандарт) бухгалтерського обліку 23 «Розкриття інформації щодо пов'язаних сторін», затверджене наказом Міністерства фінансів України від 18.06.2001 № 303, зареєстроване в Міністерстві юстиції України 23.06.2001 за № 539/5730. URL : https://ips.ligazakon.net/document/view/reg5730?an=210\&ed=2013 0627.

37. Порядок підвищення кваліфікації педагогічних і науково-педагогічних працівників, затверджений постановою Кабінету Міністрів України від 21.08.2019 № 800. URL : https://zakon.rada.gov.ua/laws/show/800-2019-п\#Text. 18\#Text.

38. Про вищу освіту : Закон України від 01.07.2014 № 1556-VII. URL : https://zakon.rada.gov.ua/laws/show/1556-

39. Про впорядкування умов оплати праці та затвердження схем тарифних розрядів працівників навчальних закладів, установ освіти та наукових установ : наказ Міністерства освіти і науки України від 26.09.2005 № 557, зареєстрований у Міністерстві юстиції України 03.10.2005 за № 1130/11410. URL: https://zakon.rada.gov.ua/laws/show/z1130-05\#Text.

40. Про затвердження Інструкції про оплату праці та розміри ставок заробітної плати професорськовикладацького складу вищих навчальних закладів : наказ Міністерства освіти України від 02.04.1993 № 90, зареєстрований у Міністерстві юстиції України 03.12.1993 за № 181. URL : https://zakon.rada.gov.ua/laws/show/z018193\#Text.

41. Про наукову і науково-технічну діяльність : Закон України від 26.11.2015 № 848-VIII. URL : https://zakon.rada.gov.ua/laws/show/848-19\#Text. 19\#n2093.

42. Про освіту : Закон України від 05.09.2017 № 2145-VIII. URL : https://zakon.rada.gov.ua/laws/show/2145-

43. Про професійний розвиток працівників : Закон України від 12.01 .2012 № 4312-VI. URL: https://zakon.rada.gov.ua/laws/show/4312-17\#Text.

44. Про упорядкування структури апарату центральних органів виконавчої влади, їх територіальних підрозділів та місцевих державних адміністрацій : постанова Кабінету Міністрів України від 12.03.2005 № 179. URL: https://zakon.rada.gov.ua/laws/show/179-2005-п\#Text.

45. Сидорук $Є$. Ефективність управління персоналом сучасної організації та характеристика факторів, що ії обумовлюють / Науковий блог. Національний університет «Острозька академія» $2012 . \quad$ URL: https://naub.oa.edu.ua/2012/efektyvnist-upravlinnya-personalom-suchasnoji-orhanizatsiji-ta-harakterystyka-faktoriv-scho-jijiobumovlyuyut/

46. Сіменко І.В., Романюк М.К. Сутність і основні складові управлінського потенціалу суб'єкта господарювання. 
Актуальні проблеми економіки. 2012. № 8 (134). С. 209-218. URL : http://nbuv.gov.ua/UJRN/ape 2012827.

47. Словник іншомовних слів: 23000 слів та термінологічних словосполучень / уклад. Л.О. Пустовіт та ін. К. : Довіра, 2000. 1018 с.

48. Словник української мови : в 11 томах. 1970. T. 1. URL : http://sum.in.ua/s/administruvaty.

49. Словник української мови : в 11 томах. 1975. T. 6. URL : http://sum.in.ua/s/

50. Стандарт вищої освіти за спеціальністю 281 «Публічне управління та адміністрування» для другого (магістерського) рівня вищої освіти, затверджений наказом МOH України від 04.08.2020. № 1001. URL: https://mon.gov.ua/storage/app/media/vishcha-osvita/zatverdzeni standarty/2020/08/05/281publichne-upravlinnya-taadministruvannya-magistr.pdf.

51. Стратегія розвитку вищої освіти в Україні на 2021-2031 рр. : проект, підготовлений на виконання Указу Президента України «Про вдосконалення вищої освіти в Україні» від 03.06.2020 № 210/2020. 71 с. URL: https://mon.gov.ua/storage/app/media/rizne/2020/09/25/rozvitku-vishchoi-osviti-v-ukraini-02-10-2020.pdf.

52. Управління персоналом (2003). URL : https://library.if.ua/book/45/3054.html.

53. Управління персоналом / Library.if.ua. 2003. URL : https://library.if.ua/book/45/3054.html.

54. Управлінські кадри. Економічна енциклопедія : у трьох томах / редкол.: С.В. Мочерний (відп. ред.) та ін. К. : Видавничий центр «Академія», 2000. T. 1. 864 с. URL: http://www.ukr.vipreshebnik.ru/entsiklopediya/65-u/2873upravlinski-kadri.html.

55. Чумаченко О.В., Шульгіна Т.С. Проблеми визначення категорії «управлінський персонал підприємства» та його класифікації. Сталий розвиток економіки. 2011. № 2(5). С. 57-62. URL : https://uniep.km.ua/pdf/2 2 2011.pdf.

56. Які 8 компетентностей є ключовими з точки зору Європейської Комісії в галузі освіти? / Вінницький національний технічний університет. URL : http://ininv.vntu.edu.ua/ukr/index.php?option=com content\&view=article\&id=58:23-05-17-news-keycompetences\&catid=37\&ltemid=857.

57. Ben-Hur Sh., Barsoux J.-L. Betting on leadership development: three false paths / Real Learning. Real Impact. Research\&Knowledge. 2014. URL: https://www.imd.org/research-knowledge/articles/betting-on-leadership-developmentthree-false-paths/

58. Blaskova M., Blasko R., Matuska E., Rosak-Szyrocka J. Development of Key Competences of University Teachers and Managers. Procedia - Social and Behavioral Sciences. 2015. URL: https://www.researchgate.net/publication/277949648 Development of Key Competences of University Teachers and Managers.

59. Burquel N. Training university leaders and manager's - why and how? Leadership and Governance in Higher Education. 2012. Vol. № 1. 15 p. URL: https://www.academia.edu/15170512/Training Leaders and Managers in Higher Education.

60. Copland G. Governance in a changing environment: thought-piece. Contemporary issues in governance. June 2014. 26 p. URL : https://www.advance-he.ac.uk/knowledge-hub/governance-changing-environment-thought-piece.

61. How Presidential Evaluations Must Change / Association of Governing Boards of Universities and Colleges. 2012. Vol. 20. Numb. 1. URL : https://agb.org/trusteeship-article/how-presidential-evaluations-must-change/

62. Illustrative Practice Note 3:Academic Governance / Committee of University Chairs. 2017. 8 p. URL: https://www.universitychairs.ac.uk/wp-content/uploads/2017/01/CUC-IPN3-Academic-Governance-Jan-17.pdf.

63. Losinger I.D. The Development of University Leaders: Supporting the Professional Development Needs of University Presidents. Adult Education and the Contested Terrain of Public Policy: Proceedings of the Annual Conference of the Canadian Association for the Study of Adult Education (21st, Toronto, Ontario May $30-31$ and June 1, 2002). 2002. 438 p. P. 374-376. URL : https://files.eric.ed.gov/fulltext/ED478964.pdf.

64. Netherlands. Management and Other Education Staff / European Commission. Eurydice. URL: https://eacea.ec.europa.eu/national-policies/eurydice/content/management-and-other-education-staff-47 en.

65. Netherlands. Management Staff for Higher Education / European Commission. Eurydice. URL : https://eacea.ec.europa.eu/national-policies/eurydice/content/management-staff-higher-education-47 en.

66. Ukraine Higher Education Leadership Development Programme.

URL :

https://www.britishcouncil.org.ua/en/programmes/education/past-projects/leadership-development. 


\title{
Теоретичні основи рейтингування як інструменту оцінювання діяльності науково-педагогічних працівників університетів України
}

\author{
Ольга Ярошенко, \\ доктор педагогічних наук, професор, \\ дійсний член НАПН України, \\ головний науковий співробітник, \\ Відділ інтеграції вищої освіти і науки, \\ Інститут вищої освіти НАПН України, \\ https://orcid.org/0000-0003-1555-0526
}

Анотація. У розділі розкрито трактування понять рейтинг, рейтингування професійної діяльності науково-педагогічних працівників, показники й індикатори рейтингового оцінювання діяльності науковопедагогічних працівників. Обґрунтовано теоретичні основи рейтингування як інструменту оцінювання діяльності науково-педагогічних працівників університетів України: мету, об'єкт, суб'єкт, принципи, умови, функції, роль і призначення рейтингового оцінювання діяльності науково-педагогічних працівників в особистісному й інституційному вимірах.

3'ясовано роль рейтингів у забезпеченні якості вищої освіти. Наголошено на необхідності: а) оптимального поєднання кількісних і якісних показників діяльності науково-педагогічних працівників під час проведення рейтингового оцінювання; б) запровадження нових якісних показників реалізації викладачем студентоцентрованого підходу у підготовці майбутніх фахівців; в) встановлення динаміки розвитку 57 професійної діяльності науково-педагогічного працівника упродовж певного часового хронотопу; г) проведення прогностичного аналізу результатів рейтингового оцінювання.

Окреслено ризики, наявність яких перешкоджає успішному проведенню процедури рейтингування.

Ключові слова: автономія 3ВО, індикатори, кількісні і якісні показники професійної діяльності, науково-педагогічні працівники, рейтинг, рейтингове оцінювання, студентоцентризм, теоретичні основи, умови, функції. 


\section{Постановка проблеми та її актуальність}

Пріоритетом національної освітньої політики є забезпечення якості вищої освіти, яке безпосередньо залежить від спроможності науково-педагогічних працівників (далі - НПП) провадити на належному рівні «... навчальну, методичну, наукову (науково-технічну, мистецьку) та організаційну діяльність» (ст. 53) ${ }^{1}$. Під впливом глобалізаційних процесів, детермінованих входженням України до Європейського освітнього і дослідницького просторів, у вітчизняній практиці забезпечення якості вищої освіти поширеними стають рейтинги 3ВО, один із них - рейтинг університетів «ТОП 200 Україна». Показник інтегрованого індексу, що робить співставними результати діяльності університетів різних типів у цьому рейтингу, включає три індекси: якість науково-педагогічного потенціалу, якість навчання, індекс міжнародного визнання ${ }^{2}$. Цілком очевидним є вплив результатів професійної діяльності НПП на цей рейтинг. У Паризькому комюніке (Paris Communiqué, 2018) наголошується: «Оскільки високоякісне викладання має суттєве значення для сприяння високоякісній освіті, то просування в академічній кар'єрі має будуватися на підставі успішних досліджень та якості викладання» ${ }^{3}$. Все вищезазначене не полишає місця для недооцінювання рейтингування діяльності НПП.

Практика рейтингового оцінювання досить поширена в різних сферах людської діяльності, в тому числі освітній. Закон України «Про вищу освіту» надає ЗВО право «запроваджувати рейтингове оцінювання освітніх, науково-дослідницьких та інноваційних досягнень учасників освітнього процесу» (ст. 32) ${ }^{4} .3$ часу впровадження Міністерством освіти і науки України рейтингової системи оцінювання НПП (2007 рік) щорічне рейтингування професійної діяльності НПП стало для ЗВО звичним явищем. Як своєрідне підведення підсумків щорічної діяльності НПП воно дозволяє визначати лідерів викладацької і наукової діяльності і на цій підставі здійснювати моральне та матеріальне заохочення, відзначати кращих із кращих (присвоєння почесних університетських звань, призначення премій, надбавок, укладання та продовження контракту 3 викладачем тощо). Проте місія рейтингового оцінювання діяльності НПП значно вагоміша. Вона полягає у підвищенні професійної компетентності НПП і підвищенні мотивації професійної діяльності; забезпеченні якості вищої освіти конкретного ЗВО; створенні умов для одержання високих результатів у вітчизняних світових рейтингах. В управлінському сенсі рейтингове оцінювання створює інформаційно-статистичну базу для різнобічного аналізу й оцінки кадрового потенціалу 3ВО, його спроможності забезпечувати високу якість надання освітніх послуг, прийняття управлінських рішень щодо підвищення кваліфікації НПП, їхнього кар'єрного зростання. Цілком закономірно, що у нормативних документах 3ВО, що стосуються організації і проведення рейтингового оцінювання професійної діяльності НПП, наголошується на ролі цієї процедури у забезпеченні якості вищої освіти.

Із двох способів встановлення рейтингу науково-педагогічних працівників - створення рейтингових інституцій й автономного проведення рейтингу університетами -Україна обрала другий. Задля цього заклади розробляють, періодично удосконалюють та змінюють зміст положень, що регламентують процедуру рейтингового оцінювання діяльності НПП ${ }^{5}$. В умовах інституційної автономії ці нормативні документи певною мірою різняться індикаторами і кількісними вимірами, аналітико-прогностичними тлумаченнями результатів та їх подальшим використанням. Натепер накопичена чимала кількість фактів про процедуру і результати встановлення рейтингів НПП. В умовах посилення університетської автономії ці факти потребують всебічного аналізу та узагальнення, що дозволить обгрунтувати теоретичні основи рейтингування як інструменту оцінювання професійної діяльності науково-педагогічного працівника. Потреба в цьому $\epsilon$ актуальною, тому що рейтингове оцінювання професійної діяльності НПП важливе не лише особисто для них, але й дає змогу бачити цілісну картину здобутків університету із подальшим з'ясуванням його місця в соціумі.

Із метою одержання та вивчення наукової інформації про рейтингування як явище університетської дійсності та подальшого використання одержаних результатів для обґрунтування теоретичних основ рейтингування як інструменту оцінювання діяльності НПП університетів України було використано сукупність методів наукового дослідження: аналіз, синтез, конкретизація, порівняння, індукція, дедукція.

\footnotetext{
1 Про вищу освіту : Закон України від 01.07.2014 № 1556-VII. URL : http://zakonO.rada.gov.ua/laws/show/1556-18.

2 Центр міжнародних досліджень «Євроосвіта»: веб-сайт. URL : http://euroosvita.net/index.php/?category=11\&id=6556.

3 Паризьке комюніке (Париж, 25 травня 2018 р.). URL: https://mon.gov.ua/storage/app/media/news/Hoвини/2018/06/06/12/pariscommuniqueenua2018.pdf.

${ }^{4}$ Про вищу освіту : Закон України від 01.07.2014 № 1556-VII. URL : http://zakon0.rada.gov.ua/laws/show/1556-18.

5 Житомирський державний університет імені Івана Франка. URL: https://zu.edu.ua/; Сумський державний університет. URL: https://www.sumdu.edu.ua/uk/; Харківський національний університет імені B.H. Каразіна. URL : https://www.univer.kharkov.ua/
} 


\section{Аналіз вітчизняних і зарубіжних документів і публікацій, дотичних до проблеми дослідження}

На законодавчому рівні ключовими документами щодо рейтингового оцінювання діяльності науковопедагогічних працівників вітчизняних ЗВО є Закон України «Про вищу освіту» ${ }^{6}$, Закон України «Про наукову ma науково-технічну діяльність ${ }^{7}$, у світлі яких ця процедура постає складовою системи забезпечення якості вищої освіти. Так, статтею 16 Закону України «Про вищу освіту» що стосується системи забезпечення якості вищої освіти, передбачається «щорічне оцінювання здобувачів вищої освіти, науково-педагогічних і педагогічних працівників закладу вищої освіти та регулярне оприлюднення результатів таких оцінювань на офіційному веб-сайті закладу вищої освіти, на інформаційних стендах та в будь-який інший спосіб» 8 . Автономія та самоврядування надають ЗВО право «запроваджувати рейтингове оцінювання освітніх, мистецьких, науково-дослідницьких та інноваційних досягнень учасників освітнього процесу» (ст. 32$)^{9}$.

Підсумки діяльності університетів у різного рівня рейтингах передбачають оцінювання за індикаторами, що стосуються таких складників суспільної місії 3ВО, як викладання, наукові дослідження, розповсюдження знань, міжнародна співпраця. Тому цілком логічно, що наявні у кожного ЗВО положення про оцінювання діяльності науково-педагогічних працівників також включають ці складові до викладацьких рейтингів. Як засвідчують нормативні документи 3ВО, на підставі яких кожен університет встановлює рейтинги НПП 10;11; 12 та ін., місія рейтингування визначається співвідносно з пріоритетними для конкретного ЗВО завданнями діяльності. Відтак, в частині показників й індикаторів рейтингового оцінювання діяльності НПП проявляється як спільне, так і відмінне. Зокрема, спільними є види діяльності, що підлягають рейтинговому оцінюванню. Відмінність простежується у кількісному (бали) оцінюванні одного й того ж складника професійної діяльності науково-педагогічного працівника.

У Великому тлумачному словнику сучасної української мови наведено таке визначення: «рейтинг це показник оцінки діяльності, популярності, авторитету якоїсь особи, організації, групи, програм у певний час, що визначається соціологічним опитуванням, голосуванням та ін., і визначається місцем, яке вони посідають серед собі подібних» ${ }^{13}$. Вітчизняні дослідники О. Верес, В. Пасічник, Л. Чирун у статті «/нформаційна модель системи формування рейтингових списків кафедр університету» зазначають, що «Рейтинг (від англ. - rating) - це індивідуальний числовий показник оцінки досягнень деякого суб'єкта в класифікаційному списку, який щорічно складається експертами відповідних галузей. Фактично «рейтинг»це система впорядкування у вигляді списку якості будь-яких об'єктів на основі кількісних показників, або рейтингових оцінок» ${ }^{14}$. Цілком очевидно, що стосовно 3 ВО і професійної діяльності НПП результати рейтингу можна трактувати як інформаційний продукт, який ілюструє місце науково-педагогічного працівника серед інших, котрі обіймають однакову з ним посаду. Послуговуючись філософськими категоріями загального й одиничного ${ }^{15}$, рейтинг університету відносимо до категорії загального, рейтинг науково-педагогічного працівника - до одиничного. Ці категорії відображають не лише відмінність, але й діалектичну єдність рейтингових процедур на інституційному та особистісному рівнях. Звідси робимо висновок, що методологічне підґрунтя у них спільне.

3ВО, що лідирують у світових рейтингах, притаманна інтеграція освітньої та наукової складових

\footnotetext{
6 Про вищу освіту : Закон України від 01.07.2014 № 1556-VII. URL : http://zakonO.rada.gov.ua/laws/show/1556-18.

7 Про наукову і науково-технічну діяльність : Закон України від 16.10.2020 № 848-VIII. URL : https://zakon.rada.gov.ua/laws/show/84819\#Text.

8 Про вищу освіту : Закон України від 01.07.2014 № 1556-VII. URL : http://zakon0.rada.gov.ua/laws/show/1556-18.

9 Про вищу освіту : Закон України від 01.07.2014 № 1556-VII. URL : http://zakonO.rada.gov.ua/laws/show/1556-18.

10 Положення про планування роботи, звітування й оцінювання науково-педагогічних працівників Харківського національного університету імені В.Н. Каразіна. URL : http://www.univer.kharkov.ua/docs/polozhennya/zvituvannya21042017.pdf.

11 Положення про організацію оцінювання здобувачами вищої освіти якості освітньої діяльності при вивченні навчальних дисциплін в Сумському державному університеті. URL: https://normative.sumdu.edu.ua/?task=getfile\&tmpl=component\&id=7c7de133-99aa-e7118a45-001a4be6d04a\&kind=1.

12 Положення про оцінювання роботи науково-педагогічних працівників кафедри та визначення їхніх рейтингів / Львів : Національний університет «Львівська політехніка», 2015. URL: http://test2016.lp.edu.ua/sites/default/files/attach/2016/1674/ polozhennya_pro_ocinyuvannya_vykladachiv.pdf.

13 Великий тлумачний словник сучасної української мови (з дод. і допов.) / ред. В.Т. Бусел. Київ, Ірпінь, 2005. С. 2010.

${ }^{14}$ Верес О.М., Пасічник В.В., Чирун Л.Б. Інформаційна модель системи формування рейтингових списків кафедр університету. Вісник Національного університету «Львівська політехніка». Інформаційні системи та мережі. 2008. № 610. C. 40. URL: http://vlp.com.ua/files/05.pdf.

15 Філософський енциклопедичний словник / гол. ред. В.І. Шинкарук. Київ : Абрис, 2002. 742 c. URL : https://shron1.chtyvo.org.ua/ Shynkaruk Volodymyr/Filosofskyi entsyklopedychnyi slovnyk.pdf.
} 
діяльності викладачів університетів, тому серед пріоритетів рейтингового оцінювання НПП - наукові досягнення і цитування праць у виданнях, що входять до наукометричних баз 16; 17; 18; 19 . Центр міжнародних проєктів "Євроосвіта» ${ }^{20}$ в партнерстві з міжнародною групою експертів IREG (Observatory on Academic Ranking and Excellence) ${ }^{21}$ здійснив академічний рейтинг закладів вищої освіти України "Ton-200 Україна 2019» і в черговий раз підтвердилось, що з року в рік у цьому рейтингу лідирують Київський національний університет імені Тараса Шевченка і Національний технічний університет України «Київський політехнічний інститут імені Ігоря Сікорського» 22.

На основі проведеного аналізу документальної бази вітчизняних 3ВО 23;24;25;26;27;28;29 нами встановлено, що кожен з них позиціонує рейтингове оцінювання діяльності НПП у світлі головних завдань закладу, актуальних для нього на час проведення рейтингу. Так, у Порядку визначення рейтингів науковопедагогічних працівників Харківського національного університету імені В.Н. Каразіна ${ }^{30}$ наголошено, що «оцінка результативності роботи науково-педагогічних працівників університету $€$ частиною системи забезпечення якості університетської освіти. Визначення рейтингу НПП цього університету слугує стимулюванню професійної діяльності науково-педагогічних працівників, спрямовує їх діяльність на розв'язання актуальних для університету завдань у навчально-методичній та науково-дослідній діяльності» ${ }^{31}$. Огляд нормативних документів, що регламентують процедуру рейтингування діяльності НПП у різних 3ВО, показав, що такі документи витримані стосовно основних видів професійної діяльності НПП викладання, навчання, методичної, організаційної і наукової роботи. Унормованим для визначення рейтингу НПП є оцінювання в балах шляхом знаходження суми балів, якими оцінюються перелічені види діяльності науково-педагогічного працівника. Співставний аналіз близько 30 положень про рейтингове оцінювання діяльності НПП вітчизняних ЗВО показав, що здебільшого використовуються індикатори прямого вимірювання кількісних результатів діяльності. 3 експертних оцінок переважає оцінювання враження здобувачів вищої освіти про викладацьку діяльність та деякі особистісні якості НПП. Доводиться констатувати,

\footnotetext{
16 Луговий В.І., Слюсаренко О.М., Таланова Ж.В. Типовий топ-університет: кількісні та якісні параметри. Ідея університету: сучасний дискурс : монографія. Київ, 2014. С. 215-275.

17 Луговий В.І., Слюсаренко О.М., Таланова Ж.В. Світовий досвід для створення національного рейтингу закладів вищої освіти. Педагогіка і психологія. Вісник НАПН України. 2018. № 2. С. 5-23.

18 Луговий В.І., Слюсаренко О.М., Таланова Ж.В. Нові уроки лідерства для України від Шанхайського рейтингу 2018 року. Педагогіка і психологія. Вісник НАПН України. 2018. № 3. С. 5-22.

19 Луговий В.І., Таланова Ж.В. Об'єктивне і суб'єктивне оцінювання якості освіти: світовий досвід для України. Педагогіка і психологія. Вісник НАПН України. 2016. № 4. С. 32-40.

20 Центр міжнародних досліджень «Євроосвіта». URL : http://euroosvita.net/?category=28.

${ }^{21}$ IREG Observatory on Academic Ranking and Excellence. URL : http://ireg-observatory.org/en/
}

22 Вища освіта / Інформаційно-аналітичний портал про вищу освіту в Україні та за кордоном. URL: http://vnz.org.ua/novyny/podiyi/10954-opryldneno-tsogorichnyj-rejtyng-vitchyznjanyh-vyshiv-top-200-ukrayina.

23 Положення про планування роботи, звітування й оцінювання науково-педагогічних працівників Харківського національного університету імені В.Н. Каразіна. URL : http://www.univer.kharkov.ua/docs/polozhennya/zvituvannya21042017.pdf.

24 Положення про організацію оцінювання здобувачами вищої освіти якості освітньої діяльності при вивченні навчальних дисциплін в Сумському державному університеті. URL : https://normative.sumdu.edu.ua/?task=getfile\&tmpl=component\&id=7c7de133-99aa-e7118a45-001a4be6d04a\&kind=1.

25 Положення про оцінювання роботи науково-педагогічних працівників кафедри та визначення їхніх рейтингів / Національний університет «Львівська політехніка». Львів, 2015. URL: http://test2016.Ip.edu.ua/sites/default/files/attach/2016/1674/ polozhennya_pro_ocinyuvannya_vykladachiv.pdf.

${ }^{26}$ Положення про рейтингове оцінювання діяльності науково-педагогічних працівників, кафедр і факультетів Харків / Національний аерокосмічний університет ім. М.Є.Жуковського «Харківський авіаційний інститут». Харків, 2015.21 c. URL: https://www.khai.edu/uploads/editor/1/2/sitepage 16/files/xai reytynhove otsinyuvannya diyalnosti naukovo pedahohichnykh pratsivny kiv kafedr_i fakultetiv_2015.pdf.

27 Положення про систему рейтингової оцінки діяльності науково-педагогічних працівників Уманського державного педагогічного університету імені Павла Тичини. Умань : УдПУ імені Павла Тичини, 2017.22 c. URL: https://udpu.org.ua/files/news/2017/02/15/files/pol-pro-reiting.pdf.

28 Положення про рейтингове оцінювання діяльності науково-педагогічних працівників НФаУ. Харків: НФаУ, 2016. 12 c. URL: https://nuph.edu.ua/wp-content/uploads/2016/04/Положення-Рейтинг НПП.pdf.

29 Положення про рейтингову систему оцінювання діяльності науково-педагогічних працівників, кафедр, навчально-наукових інститутів, факультетів сумського державного педагогічного університету імені A.C. Maкаренка. URL: https://sspu.edu.ua/images/2019/manual/polozhennya_pro reytingovu sistemu ocinyuvannya diyalnosti_d2a31.pdf.

30 Порядок визначення рейтингів науково-педагогічних працівників Харківського національного університету імені B.H. Каразіна. URL : https://univer.kharkov.ua/docs/work/polozhennya-reiting-pracivnykiv.pdf.

31 Порядок визначення рейтингів науково-педагогічних працівників Харківського національного університету імені B.H. Kapaзіна. URL : https://univer.kharkov.ua/docs/work/polozhennya-reiting-pracivnykiv.pdf. 
що рейтингове оцінювання професійної діяльності НПП вітчизняних університетів поки-що ведеться в напрямі встановлення абсолютного результату: скільки монографій і підручників видано, статей опубліковано, призерів олімпіад підготовлено, програм розроблено тощо. Все це слушно, однак недостатньо для вичерпної оцінки праці науково-педагогічного працівника, зважаючи на вимогу бути досконалими у виконанні професійних обов'язків. Під досконалістю розуміють поєднання викладання і досліджень, а також залучення студентів до наукового пошуку з часу їхнього вступу до університету. Тому вітчизняним ЗВО не варто послуговуватись лише кількісними показниками під час рейтингового оцінювання й ігнорувати та недооцінювати якісні, одним із яких може стати студентоцентрований характер професійної діяльності нПП. Аргументуємо це тим, що натепер студентоцентризм є світовою тенденцією організації підготовки здобувачів вищої освіти, і європейський досвід забезпечення якості вищої освіти характеризується студентоцентрованим підходом до розроблення освітніх програм та їх реалізації ${ }^{32 ; 33 .}$

Аналіз дотичних до проблеми дослідження і відкритих для публічного перегляду електронних джерел (звітна документація керівників структурних підрозділів, форми для регулярного звіту про досягнення науково-педагогічних працівників тощо) Масачусетського технологічного університету ${ }^{34}$, Стенфордського ${ }^{35}$, Оксфордського ${ }^{36}$, Кембріджського ${ }^{37}$, Гарвардського ${ }^{38}$ університетів, дозволив з' ясувати схоже і відмінне у підходах до оцінювання діяльності НПП у вітчизняних і зазначених ЗВО. Схожість проявляється в автономії щодо питань встановлення рейтингу та інтерпретації одержаних результатів. Основна відмінність полягає в тому, що загальноприйнятими рейтинговими критеріями виступають наукові досягнення НПП, а індикаторами служать публікації у міжнародних і національних індексованих виданнях. Пояснити це можна тим, що у світових рейтингах престиж зарубіжних університетів визначається більшою мірою досягненнями викладачів у дослідницькій, а не викладацькій діяльності. Новим, порівняно з вітчизняними практиками, виявлено:

- зазначення у бланку самооцінки планів науково-педагогічного працівника на майбутній рік та очікуваної від керівництва допомоги ${ }^{39}$, а також перспектив професійного зростання ${ }^{40}$;

- в оцінюванні акцентується на професійному розвитку викладача, увага зосереджується на щорічному зростанні досягнень, зокрема, на основних здобутках та труднощах у досягненні поставлених завдань, на можливостях професійного зростання та напрямах додаткових тренувань ${ }^{41}$;

- рейтингування здійснюється керівником підрозділу і налічує п’ять рівнів: визначний, вище очікуваного, згідно очікувань, нижче очікуваного, незадовільний 42 ;

- оцінювання діяльності НПП виступає складовою управління професійною кар'єрою, досягнення НПП розглядаються й аналізуються у Центрі особистого та професійного розвитку (Centre for Personal and Professional Development) ${ }^{43}$;

- оцінюванню підлягають не НПП, а дисципліни, які вони викладають, за такими критеріями: якість та користь дисципліни, якість та ефективність її викладання, загальна оцінка 44

У щорічному оцінюванні викладачів Акредитаційною комісією з техніки $і$ технології АВЕT

\footnotetext{
32 Сбруєва А.А. Тенденції трансформації місії університету: порівняльно-педагогічний аналіз. Педагогічні науки: теорія, історія, інновачійні технології. 2015. № 6. С. 448-461.

33 Ярошенко О.Г. Студентоцентрований підхід до рейтингового оцінювання професійної діяльності науково-педагогічних працівників. Підготовка майбутніх учителів фізики, хімії, біології та природничих наук у контексті вимог Нової української школи : матеріали Міжнар.наук.-практ. конф. (м. Тернопіль, 14 травня 2020 р.). Тернопіль. 2020. С. 80-82.

34 Human resourses / Massachusetts Institute of Technology. URL : https://hr.mit.edu/performance/reviews/forms.

35 Human resourses group / Stanford Medicine. URL : http://med.stanford.edu/hrg/Performance.html.

36 People and Organisational Development / University of Oxford. URL : https://pod.admin.ox.ac.uk/pdr.

${ }^{37}$ Human resourses / University of Cambridge. URL: https://www.hr.admin.cam.ac.uk/policies-procedures/staff-review-anddevelopment/staff-review-and-development-appraisal.

38 Spring 2019 Cross-Registration Harvard Chan Student Evaluation Feedback / Harvard University. URL : https://cdn1.sph.harvard.edu/wpcontent/uploads/sites/2096/2019/06/Cross-Reg-Spring-2019-FINAL-6-26.pdf.

39 Human resourses group / Stanford Medicine. URL : http://med.stanford.edu/hrg/Performance.html.

40 Human resourses / Massachusetts Institute of Technology. URL : https://hr.mit.edu/performance/reviews/forms.

41 People and Organisational Development / University of Oxford. URL : https://pod.admin.ox.ac.uk/pdr.

42 Tomorrow's Professor Postings / Stanford University. URL : https://tomprof.stanford.edu/posting/1680.

${ }^{43}$ Human resourses / University of Cambridge. URL: https://www.hr.admin.cam.ac.uk/policies-procedures/staff-review-anddevelopment/staff-review-and-development-appraisal.

${ }^{44}$ Spring 2019 Cross-Registration Harvard Chan Student Evaluation Feedback / Harvard University. URL : https://cdn1.sph.harvard.edu/wpcontent/uploads/sites/2096/2019/06/Cross-Reg-Spring-2019-FINAL-6-26.pdf.
} 
(Accreditation Board for Engineering and Technology) ${ }^{45}$ враховують три параметри: наукову продукцію, якість викладання, характер та обсяг позанавчальної діяльності (рецензування, експертні послуги тощо). Для цього розроблено конкретні форми аналізу й оцінки діяльності викладача в США, де враховано вимоги з переліку інженерних критеріїв до викладачів, які проводять заняття за акредитованими програмами АВЕТ.

Характерною рисою сьогодення в університетській освіті стало формування якісно нового освітнього середовища, якому властиві інформатизація освітнього процесу, розроблення змісту нових навчальних дисциплін із подальшим їх викладанням іноземною мовою, розширення міжнародного наукового співробітництва, створення центрів колективного користування науковим обладнанням (ЦККНО), передбачене Законом України «Про наукову та науково-технічну діяльність» ${ }^{46}$. Ці та інші новації продукують нові ознаки результативності праці НПП, виявлення та оцінювання яких потребує уведення індикаторів, що не були затребувані, принаймні, 10 років тому, зокрема:

- проведення навчальних занять іноземною мовою;

- участь у міжнародних наукових / освітніх проектах

- ведення навчального контенту на персональному сайті викладача (або сторінки на сайті кафедри);

- розробка та використання комп'ютерних форм перевірки знань студентів;

- Індекс Гірша (h-index);

- кількість статей у наукометричних базах даних Scopus, Web of Science;

- стажування у закордонних організаціях (викладання у закордонних 3ВО) тощо.

На підставі з'ясованого робимо висновок, що критеріальний апарат та індикатори рейтингового оцінювання професійної діяльності НПП у багатьох вітчизняних ЗВО потребують осучаснення.

У доповіді інформаційної мережі «Eurydice» ${ }^{47}$ наголошується, що «науково-педагогічні кадри $\epsilon$ важливими для успішної вищої освіти». Також показано професійні реалії сьогодення діяльності професорсько-викладацького складу та наукових працівників 35 країн Європи під впливом змін у Європейському освітньому просторі. Вони свідчать, що фінансова автономія ЗВО має неабиякий вплив на підвищення рейтингів НПП.

На окрему увагу заслуговує участь у процедурі рейтингування НПП безпосередніх споживачів освітньої послуги - студентів, аспірантів та докторантів. І. Зварич присвятила цьому питанню свої публікації "Критерії очінювання педагогічної діяльності викладачів у вищих навчальних закладах освіти» ${ }^{48}$ та "Очінювання професійної діяльності викладачів у вищих навчальних закладах США (друга половина XX початок XXI столітmя» ${ }^{49}$. Дослідниця описує критерії оцінювання якості педагогічної діяльності викладачів у закладах вищої освіти США та розкриває погляди H. Marsh на вибір критеріїв для оцінювання професійної діяльності НПП студентами ${ }^{50}$. В закладах вищої освіти США здобувачі здійснюють оцінювання за такими критеріями: «уміння викладача зацікавити студентів вивчати навчальну дисципліну; науковість викладача і майстерність викладати навчальний предмет; широка обізнаність викладача з дисципліни, яку він викладає; менталітет і кругозір викладача; якість викладання навчальної дисципліни і вміння організувати навчальний процес у вищому закладі освіти; уміння викладача пояснити новий навчальний матеріал; ораторські здібності викладача; уболівання викладача за рівень і якість знань студентів; об'єктивність і вимогливість викладача в процесі навчання; уміння викладача доступно підготувати навчальний матеріал; використання додаткового матеріалу з навчального предмета; уміння викладача усунути труднощі у процесі вивчення навчальної дисципліни; чесність і справедливість викладача в процесі діагностування якісного рівня знань студентів; наявність організаторських здібностей керувати групою; взаємозв'язок зі студентами; уміння навчити студентів ставити запитання і вести бесіду; розвивати критичне мислення в студентів і вміння висловлювати

\footnotetext{
${ }^{45}$ Accreditation Board for Engineering and Technology. URL : https://www.abet.org/

46 Про наукову і науково-технічну діяльність : Закон України від 16.10.2020 № 848-VIII. URL : https://zakon.rada.gov.ua/laws/show/84819\#Text.

47 European Commission/EACEA/Eurydice, 2017. Modernisation of Higher Education in Europe: Academic Staff - 2017. Eurydice Report. Luxembourg : Publications Office of the European Union. URL: https://www.anefore.lu/wp-content/uploads/2017/07/EURYDICEMODERNISATION-OF-HIGHER-EDUCATION-IN-EUROPE-2017-1.pdf.

48 ЗваричІ. Критерії оцінювання педагогічної діяльності викладачів у вищих навчальних закладах освіти. Молодь і ринок. 2010. № 5 (64). С. 21-29.

49 Зварич І.М. Оцінювання професійної діяльності викладачів у вищих навчальних закладах США (друга половина XX - початок XXI століття) : монографія. Київ : Фенікс, 2014. 344 с.

50 Зварич І. Критерії оцінювання педагогічної діяльності викладачів у вищих навчальних закладах освіти. Молодь і ринок. 2010. № 5 (64). С. 21-29.
} 
власну думку; розуміння і повага студентів як неповторної особистості; наявність педагогічного вміння допомогти студентам» ${ }^{51}$. Наведений перелік вказує на те, що студенти головним чином оцінюють навчальну, методичну й організаційну діяльність НПП, причому здійснюють це з різних позицій. Це завдання є набагато складнішим, ніж може видатись на перший погляд. Річ утім, що ЗВО надають освітні послуги здобувачам вищої освіти, серед яких існує відчутна різниця в мотивації навчання. Одних цікавить лише отримання диплому про вищу освіту, другі вмотивовані на одержання знань, формування професійної компетентності, треті мріють про наукову роботу. Цілком очевидно, що кожна із названих груп сприймає працю одного й того ж самого викладача по-різному. Відтак, і бали, які вони їм виставляють, суттєво відмінні. Н. Гапон і М. Дубняк у статті "Викладач очима студентів» ${ }^{2}$ описали риси і якості НПП, яким студенти віддають перевагу, і встановили що для них важливо, щоб викладач був яскравою індивідуальністю, яка своїм прикладом мотивує до саморозвитку.

Вивчивши досвід США, І. Галецька та О. Гунько ${ }^{53}$ звернули увагу на 12 якостей викладачів, які описав R. Walker ${ }^{54}$ на підставі тривалого дослідження якостей ефективного викладача шляхом аналізу есе студентів коледжів:

«1) готовність до семінару (знання матеріалу, вчасний початок і завершення заняття);

2) оптимістичне, позитивне ставлення до студентів і педагогічної діяльності загалом (можуть оптимістично налаштувати студентів, наголошують на позитивних сторонах їхньої роботи, завжди «бачать склянку наполовину повною»);

3) високі очікування щодо всіх студентів (віра у те, що всі студенти досягнуть успіху);

4) креативність (готовність до впровадження нових технологій навчання, використання нестандартних та навіть екстраординарних методів у викладацькій діяльності);

5) чесність (надання однакових можливостей для усіх студентів, прозоре та справедливе оцінювання);

6) особистий підхід до кожного, доступність для студентів (виявлення зацікавленості до студентів, їхніх поглядів та життя, передача їм власного досвіду);

7) створення невимушеної та комфортної атмосфери в аудиторії (можуть сформувати відчуття належності до колективу у кожного студента);

8) співчутливість (розуміння проблем студента, здатність поставити себе на його місце);

9) почуття гумору (не сприймають усе надто серйозно і роблять навчання веселим);

10) повага до студентів (ніколи навмисне не принижують студентів);

11) уміння пробачати (не тримають образу на студентів за невідповідну поведінку, можуть почати кожне заняття з чистого аркуша);

12) здатність визнавати власні помилки.

R. Walker виявив, що студенти набагато більшу увагу звертають на ставлення викладача до студентів, аніж на його компетентність у своїй галузі. Ранжування показників виявило, що найважливішою якістю ідеального викладача, на думку студентів, є комунікабельність.

Серед індикаторів рейтингового оцінювання НПП студентами вітчизняних ЗВО домінують компетентнісні. Це знайшло підтвердження у статті Л. Пшеничної «Рейтинг викладача як індикатор якості освіти» ${ }^{55}$. Дослідниця наводить такі критерії оцінювання викладачів студентами:

«1. Підготовка до занять.

2. Дисциплінований, своєчасно розпочинає заняття, сумлінний, наполегливий.

3. Доступно подає навчальний матеріал.

4. Має високі ораторські здібності та вміє пояснити матеріал.

5. Вимогливий, але об'єктивний до студентів.

6. Уміє спонукати студента до підвищення якості навчання, уміє передавати свої навички іншим,

\footnotetext{
51 Зварич І.М. Оцінювання професійної діяльності викладачів у вищих навчальних закладах США (друга половина XX - початок XXI століття) : монографія. Київ : Фенікс, 2014. 344 с. С. 98.

52 Гапон Н., Дубняк М. Викладач очима студентів. Вісник Львівського університету. Серія педагогічна. 2009. Вип. 25. Ч. 1. С. 106-113.

53 Галецька І., ГунькоО. Уявлення про ідеального викладача в студентів з різною мотивацією до навчання. Вісник Львівського університету. Серія психологічні науки. 2017. Вип. 1. С. 12-20.

${ }^{54}$ Walker R. Twelve Characteristics of an Effective Teacher: A Longitudinal, Qualitative, Quasi-Research Study of In-service and Pre-service Teachers' Opinions. Educational Horizons. 2008. Vol. 87. № 1. P. 61-68. URL : https://eric.ed.gov/?id=EJ815372.

55 Пшенична Л.В. Рейтинг викладача як індикатор якості освіти. Педагогічні науки: теорія, історія, інноваційні технології. 2014. № 1 (1). С. 368-378.
} 
комунікабельний.

7. Уміє переконувати, компромісний.

8. Активізує заняття за рахунок застосування проблемних дискусій, обговорень, огляду спеціалізованих журналів, проведення ділових ігор тощо.

9. Прислуховується до побажань студентів, не переслідує за критику, не вирішує проблеми з опалу.

10. Компетентний у матеріалі навчальної дисципліни, має високі професійні знання.

11. Ініціативний і винахідливий у навчально-виховній роботі.

12. Надає можливості продемонструвати свої здібності всім студентам групи.

13. Раціонально використовує час навчального заняття.

14. Мова викладача.

15. Контакт з аудиторією, уміння виступати перед студентами.

16. Проводить достатню кількість консультацій у зручний для студентів час.

17. Навчально-методичний матеріал (конспект лекцій, методичні вказівки, роздатковий матеріал тощо) підготовлений якісно, є простим і доступним для використання.

18. Зовнішній вигляд відповідає загально прийнятим нормам офіційного спілкування.

19. Тримає самоконтроль, увагу, дотримується етичних норм, має почуття гумору, креативний.

20. Загальна оцінка викладача як педагога й особистості.

Оцінки виставляються за шкалою:

«5» - повністю відповідає критерію;

«4» - загалом відповідає критерію, але має незначні недоліки;

«3»- лише частково відповідає критерію;

«2»- повністю не відповідає критерію» ${ }^{56}$.

Вітчизняним ЗВО властиве встановлення рейтингування кафедр. Розцінюємо це як позитив, оскільки НПП надається можливість бачити і співставляти колективний здобуток із здобутками інших кафедр, об'єктивніше оцінювати власну діяльність. У цьому сенсі заслуговує уваги стаття О. Верес, В. Пасічник, Л. Чирун «Інформачійна модель системи формування рейтингових списків кафедр університету», яка знайомить з інформаційною моделлю системи формування рейтингових списків кафедр університету та системою показників для визначення рейтингу кафедри ${ }^{57}$. Рейтингування діяльності НПП університетів потребує належного інформаційного забезпечення, за допомогою якого інформація збирається, опрацьовується, зберігається тощо. Задля цього ЗВО створюють відповідні інформаційні системи. Прикладом публікацій, що описують інформаційні системи рейтингування діяльності НПП закладів вищої освіти, $є$ стаття А. Пукас, А. Сімак, В. Вітенко «/нформаційна система рейтингування діяльності науково-педагогічних працівників закладів вищої освіти» ${ }^{58}$. С. Мороз, С. Домбровська, В. Мороз у статті "Рейтинг науковопедагогічних працівників як складова системи державного управління якістю вищої освіти» ${ }^{59}$ обґрунтовують місце та роль рейтингів НПП в системі державного управління якістю вищої освіти. У публікації акцентується на необхідності аналітико-прогностичного опрацювання одержаних рейтингових результатів, проведення порівняння досягнень і потенціалу НПП за результатами кількарічних рейтингів.

Узагальнення результатів аналізу зазначених нами праць вітчизняних авторів вказує на те, що в них розглянуто окремі складові процедури рейтингового оцінювання діяльності НПП без належної інтеграції їх в єдину систему. Диференціація рейтингів НПП вітчизняних університетів натепер здійснюється здебільшого за посадами. Тому вбачаємо сенс у більш гнучкій диференціації на зразок існуючої у Житомирському університеті імені Івана Франка ${ }^{60}$. Тут рейтинги встановлюють окремо для молодих та досвідчених викладачів, котрі обіймають однакові посади, а також за напрямами підготовки здобувачів вищої освіти:

\footnotetext{
56 Пшенична Л.В. Рейтинг викладача як індикатор якості освіти. Педагогічні науки: теорія, історія, інноваційні технології. 2014. № 1 (1). С. 368-378. С. 374-375.

57 Верес О. М., Пасічник В.В., Чирун Л.Б. Інформаційна модель системи формування рейтингових списків кафедр університету. Вісник Національного університету «Львівська політехніка». Інформаційні системи та мережі. Львів : Львівська політехніка, 2008. № 610. C. 40-51. URL : http://vlp.com.ua/files/05.pdf.

58 Пукас А.В., Сімак А.Ю., Вітенко В.В. Інформаційна система рейтингування діяльності науково-педагогічних працівників закладів вищої освіти. URL : http://dspace.tneu.edu.ua/bitstream/316497/36059/1/Пукас А.В., Сімак А.Ю., Вітренко В.В.pdf.

59 Мороз С.А, Домбровська С.М., Мороз В.М. Рейтинг науково-педагогічних працівників, як складова системи державного управління якістю вищої освіти. Вісник Національного університету цивільного захисту України. Серія: Державне управління. 2017. Вип. 2. C. 294-309. URL : http://nbuv.gov.ua/UJRN/VNUCZUDU 2017239.

60 Положення про щорічне рейтингове оцінювання наукової діяльності науково-педагогічних, педагогічних працівників жду імені Івана Франка. URL : https://zu.edu.ua/offic/naukovec roku.pdf.
} 
історико-філософським, психолого-педагогічним, природничо-математичним тощо. Запропонований підхід посилює об'єктивність рейтингового оцінювання діяльності НПП.

Як свідчить документальна база внутрішнього оцінювання якості вищої освіти вітчизняних 3ВО, рейтингове оцінювання праці НПП базується на встановленні абсолютного результату: скільки монографій і підручників видано, статей опубліковано, призерів олімпіад підготовлено, навчальних програм розроблено тощо. Все це цілком правильно, однак недостатньо для вичерпної оцінки внеску НПП у розбудову вищої освіти, ії входження до Європейського освітнього простору. Рейтингування як інструмент оцінювання діяльності НПП має скористатись зарубіжним досвідом і перейти із кількісної площини (облік зробленого) у якісну (які зміни відбуваються на особистісному та інституційному рівнях, які тенденції спостерігаються в них). Вивчення документів 3ВО, проведений аналіз наукових праць за темою дослідження та дотичної до неї теми світових рейтингів університетів ${ }^{61 ; 62 ; 63 ; 64}$, дозволив встановити, що рейтингове оцінювання діяльності НПП потребує глибокого аналізу і системного узагальнення задля обґрунтування теоретичних основ цього процесу.

\footnotetext{
61 Луговий В.І., Слюсаренко О.М., Таланова Ж.В. Типовий топ-університет: кількісні та якісні параметри. Ідея університету: сучасний дискурс : монографія. Київ, 2014. С. 215-275.

62 Луговий В.І., Слюсаренко О.М., Таланова Ж.В. Світовий досвід для створення національного рейтингу закладів вищої освіти. Педагогіка і психологія. Вісник НАПН України. 2018. № 2. С. 5-23.

63 Луговий В., Слюсаренко О., Таланова Ж. Від акредитації до рейтингу (функціонування VS розвиток). Університети i лідерство. 2018. № 2 (6). С. 3-20. URL : https://ul-journal.org/index.php/journal/article/view/77/73.

64 Луговий В.І., Слюсаренко О.М., Таланова Ж.В. Реалізація дослідницько-інноваційного потенціалу університетів як невід'ємного складника їх діяльності. Наука та наукознавство. 2019. № 3 (105). С. $26-45$.
} 


\section{Обґрунтування теоретичних основ рейтингового оцінювання діяльності науково-педагогічних працівників університетів України}

Обгрунтування проведено з дотриманням таких конщептуальних положень:

- інноваційний характер реалізації освітньої місії вітчизняних ЗВО потребує переосмислення підходів до організації та проведення рейтингового оцінювання діяльності НПП;

- двосуб'єктність освітнього процесу, європейський досвід забезпечення якості вищої освіти на основі студентоцентризму детермінують необхідність збільшення участі здобувачів вищої освіти у складанні рейтингів викладачів та використанні одержаних результатів;

- чіткі діагностичні і прогностичні цілі рейтингового оцінювання діяльності НПП дозволяють використовувати одержані результати натепер і в довгостроковій перспективі;

- просування НПП в академічній кар'єрі має відбуватись із урахуванням результатів рейтингу;

- провідними параметрами рейтингового оцінювання діяльності НПП мають бути не лише кількісні, але і якісні показники, що стосуються наукової і навчально-методичної продукції, ефективності викладання, характеру та обсягу позанавчальної діяльності;

- критерії рейтингування не повинні обмежуватись досягнутим у професійній діяльності НПП (носити статичний характер), а відображати особистісно-орієнтований і творчий характер їхньої праці і динаміку кар'єрного зростання.

\section{Характеристика рейтингування діяльності НПП як процесу}

Побудова рейтингу і проведення рейтингового оцінювання діяльності НПП - непростий і важливий процес системного управління якістю освіти, виявлення професійної активності тих, хто навчає. Тому мета рейтингового оцінювання діяльності НПП полягає в оцінці професійних досягнень НПП і сприянні наданню якісної освіти ії здобувачам відповідно з міжнародними стандартами освітньої діяльності та наукових досліджень.

Об'єктом рейтингового оцінювання виступають кількість і якість професійних видів діяльності, виконаних науково-педагогічним працівником упродовж навчального року чи інший часовий період.

Суб'єктами рейтингового оцінювання $є$ НПП, завідувачі кафедр, здобувачі вищої освіти, керівництво 3ВО, структурні підрозділ 3ВО, на які покладено обов'язки збирання й оброблення остаточних результатів рейтингування.

Перед рейтингуванням діяльності НПП ставляться завдання:

1) виявити та оцінити результативність і якість професійної діяльності НПП упродовж певного проміжку часу;

2) встановити особистий рейтинг науково-педагогічного працівника, кафедри;

3) зібрати матеріал, обробка якого дозволить керівництву ЗВО приймати управлінські рішення щодо кадрового потенціалу університету, підвищення кваліфікації НПП, створення сприятливих умов праці і розвитку професійної їхньої компетентності;

4) з'ясувати й оцінити професійні здобутки НПП, спланувати подальше їх зростання.

Соціальне значення розв'язання завдань рейтингування полягає у безпосередньому й опосередкованому впливові процедури рейтингового оцінювання на діяльність НПП та якість освітніх послуг закладів вищої освіти, імідж 3ВО в освітньо-науковому просторі.

\section{Функції рейтингування діяльності НПП}

Інформаційна (дозволяє керівництву ЗВО отримувати інформацію про стан і розвиток кадрового потенціалу, надавати абітурієнтам інформацію про університет, а його студентам - про рівень професійної компетентності тих, хто їх навчає).

Іміджева (створює імідж 3ВО на ниві освітніх послуг і в наукових колах).

Стимулююча (розвиває прагнення НПП покращувати власні показники, спонукає до кар'єрного зростання).

Аналітико-прогностична (рейтинги слугують матеріалом для аналізу і порівняння, встановлення спільного і відмінностей, складання прогнозів та формулювання пропозицій щодо подальшої діяльності НПП, а також удосконалення умов їхньої праці і підвищення кваліфікації.

Управлінська (на основі встановлених рейтингів НПП приймаються управлінські рішення щодо 
зміцнення науково-педагогічного потенціалу університету, відзначення і преміювання НПП і кафедр тощо).

Поліфункціональність рейтингу науково-педагогічних працівників дає можливість представити його функції у двох вимірах - особистісному (стосується НПП) й інституційному (відноситься до 3ВО).

Особистісний вимір:

- підвищення продуктивності праці;

- формування потреби у професійному розвитку;

- виявлення потенційних можливостей кар'єрного зростання;

- об'єктивне оцінювання наукової і викладацької спроможності;

- можливість співставляти власні досягнення з досягненнями колег із кафедри, факультету;

- спонука до самопізнання і самоосвіти;

- діагностування професійної компетентності НПП;

- з'ясування ставлення студентів до науково-педагогічного працівника;

- сприяння формуванню репутації і визнання колегами;

- моральне і матеріальне винагородження за працю;

- підвищення викладацької конкурентоспроможності як умови зарахування на роботу;

- виявлення сильних і слабких сторін власної професійної діяльності, змін у професійній компетентності.

Інституційний вимір:

- забезпечення університету лідерських позицій у пошуку нових ефективних способів надання якісної вищої освіти;

- створення системи мотивації викладачів до підвищення особистого рейтингу;

- посилення зацікавленості викладачів у підвищенні професійної кваліфікації та створення для цього відповідних умов;

- впровадження інноваційних підходів в освітній процес і дослідницьку діяльність;

- нарощування співпраці із світовим науковим співтовариством;

- сприяння руху ЗВО до надання статусу дослідницького університету;

- зростання популярності серед абітурієнтів, їхньої зацікавленості у здобутті вищої освіти в конкретному закладі;

- визначення наукової і викладацької спроможності кадрового потенціалу, оптимальне формування і використання кадрового потенціалу;

- прийняття управлінських рішень щодо фінансового, матеріально-технічного забезпечення професійної діяльності НПП;

- оцінка відповідності результатів рейтингування меті, умовам й організації професійної діяльності НПП;

- створення інформаційної бази для аналізу й оцінки результатів діяльності НПП.

\section{Принципи рейтингування}

В основу рейтингового оцінювання діяльності науково-педагогічних працівників покладено такі основні положення (принципи): відповідності, достовірності, достатності об'єктивності, гласності, доповнюваності кількісних індикаторів якісними, доступності, гнучкості, диференціації, дотримання корпоративної етики.

Впровадження рейтингового оцінювання потребує створення та дотримання відповідних умов. До основних відносимо:

- готовність керівництва ЗВО і відповідного структурного підрозділу, на який покладено обов'язки з рейтингування, до забезпечення об'єктивного визначення рейтингів науково-педагогічних працівників;

- участь НПП у розробленні критеріїв та встановленні кількісних і якісних показників рейтингового оцінювання;

- належне комп'ютерне забезпечення й автоматизація роботи по збору й аналізу рейтингів НПП;

- наявність негроміздкого рейтингового інструментарію, що не потребує багато часу й зусиль для підготовки і проведення рейтингування, обробки одержаних результатів;

- проведення на основі рейтингів моніторингу змін кадрового потенціалу з подальшим розробленням заходів, що дозволяють закріплювати позитивні тенденції, уникати негативних. 
Рейтингове оцінювання як процес і рейтинг як результат не повинні залежати від виникнення перепон різного походження. Тому його організаторам слід бути обізнаними з можливими ризиками, спричиненими:

- складністю і неоднозначністю оцінювання професійної діяльності науково-педагогічного працівника, значна часка якої є творчим процесом. Це може призвести до непорозуміння і невдоволення окремих НПП результатами рейтингування;

- поліваріантністю показників і балів для оцінювання, які в межах інституційної автономії встановлюються кожним 3ВО самостійно. Це ускладнює порівняння результатів рейтингування кількох 3ВО;

- недостатньою кількістю якісних індикаторів, що до певної міри формалізує процес рейтингування і робить визнання його результатів малоактуальним для НПП, породжує сумніви в повноті і достовірності результатів рейтингування. 


\section{Висновки}

1. Рейтинг - своєрідний інформаційний продукт, що характеризує професійні досягнення науковопедагогічного працівника у навчальній, науковій, методичній й організаційній роботі, вказує на його місце серед колег. Рейтингування професійної діяльності НПП університетів відбувається на засадах інституційної автономії і виступає складового внутрішнього забезпечення якості вищої освіти. Процес і результати рейтингового оцінювання діяльності НПП мають соціальне, професійне і педагогічне значення, дозволяють приймати оптимальні управлінські рішення щодо забезпечення якості вищої освіти і спільно з іншими заходами сприяють формуванню іміджу ЗВО та досягненню ними високих результатів за показниками, що обліковуються у світових рейтингах університетів. Відповідно до цього методологія рейтингового оцінювання у дослідженні представлена системним підходом до розгляду рейтингування та його результатів.

Завдання рейтингування діяльності НПП - відстежувати й оцінювати їхні успіхи і досягнення, в тому числі: публікаційну активність, участь у підготовці кадрів вищої кваліфікації, результативність дослідницької діяльності, ефективність навчально-методичної роботи, міжнародне визнання наукової і викладацької діяльності науково-педагогічного працівника.

2. Натепер теоретичні основи оцінювання діяльності НПП університетів України перебувають на стадії розроблення. За результатами проведеного нами дослідження до теоретичних основ рейтингування як інструменту оцінювання діяльності науково-педагогічних працівників університету на засадах інституційної автономії віднесено: мету проведення рейтингування, об'єкт, суб'єкт, концептуальні положення, принципи, умови, функції рейтингового оцінювання діяльності НПП, особистісний й інституційний виміри процедури рейтингування. Їх єдність і взаємний вплив забезпечують рейтингуванню реалізацію функції інструменту оцінювання діяльності науково-педагогічних працівників університетів України.

Результати рейтингування надають керівництву ЗВО змогу обирати ефективні способи поліпшення освітнього середовища, підвищення активності НПП в усіх видах професійної діяльності, здійснювати їхнє моральне й матеріальне стимулювання. Це дає можливість не лише об'єктивно характеризувати стан і результати професійної діяльності НПП, а й прогнозувати та попереджати можливі недоліки у їхній роботі і процедурі рейтингового оцінювання.

3. Встановлено, що, на відміну від зарубіжних університетів світового рівня, у вітчизняних ЗВО процедура рейтингового оцінювання діяльності НПП носить статичний характер, загальноприйнятими в ній $\epsilon$ кількісні показники досягнутого у професійній діяльності. Задля виконання поставлених державою завдань розвитку вищої освіти рейтингове оцінювання діяльності науково-педагогічних працівників має стати динамічним, поповнитись індикаторами оцінювання студентоцентрованого характеру освітнього процесу. Важливо не обмежуватись встановленням рейтингів, а на їх підставі вживати заходи щодо професійного зростання НПП, створювати умови для підвищення їхньої кваліфікації, в першу чергу у тих видах діяльності, що характеризуються низькими рейтинговими показниками. 


\section{Список використаних джерел}

1. Великий тлумачний словник сучасної української мови (з дод. і допов.) / ред. В.Т. Бусел. Київ, Ірпінь, 2005. C. 2010.

2. Верес О.М., Пасічник В.В., Чирун Л.Б. Інформаційна модель системи формування рейтингових списків кафедр університету. Вісник Національного університету «Львівська політехніка». Інформаційні системи та мережі. Львів : Львівська політехніка, 2008. № 610. С. 40-51. URL : http://vlp.com.ua/files/05.pdf.

3. Вища освіта / Інформаційно-аналітичний портал про вищу освіту в Україні та за кордоном. URL: http://vnz.org.ua/novyny/podiyi/10954-opryldneno-tsogorichnyj-rejtyng-vitchyznjanyh-vyshiv-top-200-ukrayina.

4. Галецька І., Гунько О. Уявлення про ідеального викладача в студентів з різною мотивацією до навчання. Вісник Львівського університету. Серія: Психологічні науки. 2017. Вип. 1. С. 12-20.

5. Гапон Н., Дубняк М. Викладач очима студентів. Вісник Львівського університету. Серія педагогічна. 2009. Вип. 25. Ч. 1. С. 106-113.

6. Житомирський державний університет імені Івана Франка. URL : https://zu.edu.ua/

7. ЗваричІ. Критерії оцінювання педагогічної діяльності викладачів у вищих навчальних закладах освіти. Молодь і ринок. 2010. № 5 (64). С. 21-29.

8. Зварич І.М. Оцінювання професійної діяльності викладачів у вищих навчальних закладах США (друга половина XX - початок XXI століття) : монографія. Київ : Фенікс, 2014. 344 с.

9. Луговий В., Слюсаренко О., Таланова Ж. Від акредитації до рейтингу (функціонування VS розвиток). Університети і лідерство. 2018. № 2 (6). С. 3-20. URL : https://ul-journal.org/index.php/journal/article/view/77/73.

10. Луговий В.І., Слюсаренко О.М., Таланова Ж.В. Нові уроки лідерства для України від Шанхайського рейтингу 2018 року. Педагогіка і психологія. Вісник НАПн України. 2018. № 3. С. 5-22.

11. Луговий В.І., Слюсаренко О.М., Таланова Ж.В. Реалізація дослідницько-інноваційного потенціалу університетів як невід'ємного складника їх діяльності. Наука та наукознавство. 2019. № 3 (105). С. $26-45$.

12. Луговий В.І., Слюсаренко О.М., Таланова Ж.В. Світовий досвід для створення національного рейтингу закладів вищої освіти. Педагогіка і психологія. Вісник НАПн України. 2018. № 2. С. 5-23.

13. Луговий В.І., Слюсаренко О.М., Таланова Ж.В. Типовий топ-університет: кількісні та якісні параметри. Ідея університету: сучасний дискурс : монографія. Київ, 2014. С. 215-275.

14. Луговий В.І., Таланова Ж.В. Об'єктивне і суб'єктивне оцінювання якості освіти: світовий досвід для України. Педагогіка і психологія. Вісник НАПН України. 2016. № 4. С. 32-40.

15. Мороз С.А, Домбровська С.М., Мороз В.М. Рейтинг науково-педагогічних працівників, як складова системи державного управління якістю вищої освіти. Вісник Національного університету цивільного захисту України. Серія: Державне управління. 2017. Вип. 2. С. 294-309. URL : http://nbuv.gov.ua/UJRN/VNUCZUDU 2017239.

16. Паризьке комюніке (Париж, 25 травня 2018 р.). URL: https://mon.gov.ua/storage/app/media/news/ Новини/2018/06/06/12/paris-communiqueenua2018.pdf.

17. Положення про організацію оцінювання здобувачами вищої освіти якості освітньої діяльності при вивченні навчальних дисциплін в Сумському державному університеті. URL: https://normative.sumdu.edu.ua/ ?task=getfile\&tmpl=component\&id=7c7de133-99aa-e711-8a45-001a4be6d04a\&kind=1.

18. Положення про оцінювання роботи науково-педагогічних працівників кафедри та визначення їхніх рейтингів / Львів : Національний університет «Львівська політехніка», 2015. URL: http://test2016.Ip.edu.ua/sites/default/ files/attach/2016/1674/polozhennya pro ocinyuvannya vykladachiv.pdf.

19. Положення про планування роботи, звітування й оцінювання науково-педагогічних працівників Харківського національного університету імені B.H. Каразіна. URL: http://www.univer.kharkov.ua/docs/polozhennya/ zvituvannya21042017.pdf.

20. Положення про рейтингове оцінювання діяльності науково-педагогічних працівників, кафедр і факультетів Харків / Національний аерокосмічний університет ім. М.Є. Жуковського «Харківський авіаційний інститут». Харків, 2015. 21 c. URL: https://www.khai.edu/uploads/editor/1/2/sitepage 16/files/xai reytynhove otsinyuvannya diyalnosti naukovo pedahohichnykh pratsivnykiv kafedr i fakultetiv 2015.pdf.

21. Положення про рейтингове оцінювання діяльності науково-педагогічних працівників НФаУ. Харків: НФаУ, 2016. 12 c. URL : https://nuph.edu.ua/wp-content/uploads/2016/04/Положення-Рейтинг НПП.pdf.

22. Положення про рейтингову систему оцінювання діяльності науково-педагогічних працівників, кафедр, навчально-наукових інститутів, факультетів сумського державного педагогічного університету імені А.С. Макаренка. URL : https://sspu.edu.ua/images/2019/manual/polozhennya pro reytingovu sistemu ocinyuvannya diyalnosti d2a31.pdf.

23. Положення про систему рейтингової оцінки діяльності науково-педагогічних працівників Уманського державного педагогічного університету імені Павла Тичини. Умань : УдПУ імені Павла Тичини, 2017.22 c. URL: https://udpu.org.ua/files/news/2017/02/15/files/pol-pro-reiting.pdf.

24. Положення про щорічне рейтингове оцінювання наукової діяльності науково-педагогічних, педагогічних працівників ЖДУ імені Івана Франка. URL : https://zu.edu.ua/offic/naukovec_roku.pdf.

25. Порядок визначення рейтингів науково-педагогічних працівників Харківського національного університету 
імені В.Н. Каразіна URL : https://univer.kharkov.ua/docs/work/polozhennya-reiting-pracivnykiv.pdf.

26. Про вищу освіту : Закон України від 01.07.2014 № 1556-VII. URL : http://zakon0.rada.gov.ua/laws/show/1556-18.

27. Про наукову і науково-технічну діяльність : Закон України від 16.10 .2020 № 848-VIII. URL: https://zakon.rada.gov.ua/laws/show/848-19\#Text.

28. Пукас А.В., Сімак А.Ю., Вітенко В.В. Інформаційна система рейтингування діяльності науково-педагогічних працівників закладів вищої освіти. URL: http://dspace.tneu.edu.ua/bitstream/316497/36059/1/ Пукас А.В., Сімак А.Ю., Вітренко В.В.pdf.

29. Пшенична Л.В. Рейтинг викладача як індикатор якості освіти. Педагогічні науки: теорія, історія, інноваційні технології. 2014. № 1 (1). С. 368-378.

30. Сбруєва А.А. Тенденції трансформації місії університету: порівняльно-педагогічний аналіз. Педагогічні науки: теорія, історія, інноваційні технології. 2015. № 6. С. 448-461.

31. Сумський державний університет. URL : https://www.sumdu.edu.ua/uk/

32. Філософський енциклопедичний словник / гол. ред. В.І. Шинкарук. Київ : Абрис, 2002. 742 c. URL: https://shron1.chtyvo.org.ua/Shynkaruk Volodymyr/Filosofskyi entsyklopedychnyi slovnyk.pdf.

33. Харківський національний університет імені В.Н. Каразіна. URL : https://www.univer.kharkov.ua/

34. Центр міжнародних досліджень «Євроосвіта». URL : http://euroosvita.net/?category=28.

35. Ярошенко О.Г. Студентоцентрований підхід до рейтингового оцінювання професійної діяльності науковопедагогічних працівників. Підготовка майбутніх учителів фізики, хімії, біології та природничих наук у контексті вимог Нової української школи : матеріали Міжнародної науково-практичної конференції. (м. Тернопіль, 14 травня 2020 р.). Тернопіль. 2020. С. 80-82.

36. Accreditation Board for Engineering and Technology. URL : https://www.abet.org/

37. European Commission/EACEA/Eurydice, 2017. Modernisation of Higher Education in Europe: Academic Staff 2017. Eurydice Report. Luxembourg : Publications Office of the European Union. URL: https://www.anefore.lu/wpcontent/uploads/2017/07/EURYDICE-MODERNISATION-OF-HIGHER-EDUCATION-IN-EUROPE-2017-1.pdf.

38. Human resourses / Massachusetts Institute of Technology. URL : https://hr.mit.edu/performance/reviews/forms.

39. Human resourses / University of Cambridge. URL : https://www.hr.admin.cam.ac.uk/policies-procedures/staffreview-and-development/staff-review-and-development-appraisal.

40. Human resourses group / Stanford Medicine. URL : http://med.stanford.edu/hrg/Performance.html.

41. IREG Observatory on Academic Ranking and Excellence. URL : http://ireg-observatory.org/en/

42. People and Organisational Development / University of Oxford. URL : https://pod.admin.ox.ac.uk/pdr.

43. Spring 2019 Cross-Registration Harvard Chan Student Evaluation Feedback / Harvard University. URL: https://cdn1.sph.harvard.edu/wp-content/uploads/sites/2096/2019/06/Cross-Reg-Spring-2019-FINAL-6-26.pdf.

44. Tomorrow's Professor Postings / Stanford University. URL : https://tomprof.stanford.edu/posting/1680.

45. Walker R. Twelve Characteristics of an Effective Teacher: A Longitudinal, Qualitative, Quasi-Research Study of Inservice and Pre-service Teachers' Opinions. Educational Horizons. 2008. Vol. 87. № 1. P.61-68. URL: https://eric.ed.gov/?id=EJ815372. 


\title{
Теоретичні основи оцінювання та розвитку науково-педагогічних працівників університетів у контексті реалізації наукової діяльності
}

\author{
Ірина Регейло, \\ доктор педагогічних наук, старший науковий співробітник, \\ головний науковий співробітник, \\ Відділ інтеграції вищої освіти і науки, \\ Інститут вищої освіти НАПН України \\ https://orcid.org/0000-0003-0512-2456
}

Анотація. У розділі представлено основні тенденції оцінювання та розвитку науково-педагогічних працівників університетів у контексті реалізації наукової діяльності в зарубіжному та вітчизняному просторах. Висвітлено законодавчі та нормативно-правові документи, які регламентують цей процес. Розкрито концептуальні засади оцінювання і розвитку дослідницької діяльності викладачів університету та запропоновано авторське визначення дефініції. Проаналізовано основоположні принципи політики ЄС та інших країн щодо оцінювання дослідницької діяльності вчених університету та визначено ключові принципи, дотримання яких зумовить ефективне оцінювання вчених у вітчизняних ЗВО. Обґрунтовано етапи та запропоновано основні види і показники оцінювання наукової діяльності науково-педагогічних працівників університетів.

Ключові слова: альтметрика, відкрита наука, досконалість, дослідницька діяльність, науковопедагогічні працівники, наукова діяльність, наукометричні показники, оцінювання, якість. 


\section{Актуальність проблеми оцінювання та розвитку науково-педагогічних працівників університетів у контексті реалізації наукової діяльності}

у сучасних умовах світової пандемії COVID-19 у системі вищої освіти відбувається скорочення фінансового забезпечення і зростають вимоги до академічного персоналу, зокрема до його добору, оцінювання та вибудовування кар'єрного зростання. Незважаючи на те, що університетські місії полягають у служінні суспільству та розвитку людського капіталу на основі провадження вищої освіти, досліджень та інновацій ${ }^{1}$, простежується тенденція щодо невідповідності між тим, що є значущим для суспільства, і тим, що оцінюється, мотивується і винагороджується в закладах вищої освіти (ЗВО). Відтак оцінювання наукової діяльності вчених і їх розвиток здебільшого звужується до кількісних показників статей, опублікованих у журналах, які внесені до наукометричних баз даних ${ }^{2}$. Зрозуміло, що наявність високої публікаційної активності надає змогу: науково-педагогічним працівникам (далі - НПП) успішно проходити атестаційний процес, займати вищі рейтингові місця у ЗВО, здійснювати кар'єрний розвиток, одержувати винагороди. вигравати грантові проєкти; керівникам 3ВО - враховувати наукометричні показники при укладанні контракту при прийнятті на роботу; закладам вищої освіти - брати участь у формуванні національних і світових рейтингів 3ВО, одержувати фінансування наукових проєктів тощо ${ }^{3}$.

На перший погляд позитивний результат наведеного переліку не викликає сумніву, водночас за межами оцінювання залишилася якість наукової діяльності вченого і якість досліджень, що не завжди сприяє широкомасштабному впровадженню відкритого доступу до наукових публікацій відповідно до принципів Open Science ${ }^{4}$. Особливо зазначена проблема набула певної невідкладності в умовах світової пандемії COVID-19, оскільки через інтенсивне посилення цифровізації освітнього і наукового процесів, велику роботу дослідники проводять у соціальних мережах, які швидкими темпами набувають широкої популярності, що забезпечує досліднику відповідну «видимість» не тільки для наукової чи освітньої спільноти, але і для суспільства загалом. Усе це також впливає на об'єктивне призначенню винагород і відповідних стимулів академічному персоналу ${ }^{5}$. Крім того, нерідко викладачі відчувають з боку адміністрації університетів «тиск на ефективність» їх роботи щодо проведення досліджень і недостатньої кількості публікацій у престижних журналах, бажаної цитованості наукових праць, викладання чи підвищення кваліфікації ${ }^{6} .3$ метою реагування на зазначені виклики важливою є підтримка академічного персоналу, про що наголошується у Final Draft 6 of the Rome Ministerial Communiqué (2020) ${ }^{7}$, зокрема щодо стабільності у «кар'єрному розвитку, паритету поваги до викладання і досліджень, привабливих умов роботи, доступу до сучасного підвищення кваліфікації та визнання досягнень» ${ }^{8}$.

Саме тому постає необхідність у розробленні ефективних інструментів оцінювання наукової діяльності та розвитку НПП університетів з урахуванням якісних і кількісних вимірів здобутих результатів.

\footnotetext{
${ }^{1}$ EURASHE's 10 Commitments for the EHEA in 2020 - Vision \& Strategies. Brussels : EURASHE, $2012 . \quad$ P. 4. URL: https://www.eurashe.eu/library/mission-phe/EURASHE_10_Commitments_for_EHEA_in_2020_March2010.pdf.

${ }^{2}$ Saenen B., Borrell-Damián L. Reflections on University Research Assessment: key concepts, issues and actors. (2019). P.6. URL: https://eua.eu/resources/publications/825:reflections-on-university-research-assessment-key-concepts,-issues-and-actors.html.

${ }^{3}$ Захарін С. Про наукову роботу закладів вищої освіти. URL: http://osvita.ua/blogs/77860/?fbclid=IwAR2U6An3lalpj7BkOSozX8vCA8wfjdySnwZr3B9nROyOPfwPczVhyiO9Sk.

${ }^{4}$ Open Science. URL : https://ec.europa.eu/digital-single-market/en/open-science.

${ }^{5}$ Morais R., \& Borrell-Damián L. (2018). Open Access 2016-2017 EUA Survey Results. Brussels: EUA. Retrieved 6 December 2018, from: https://eua.eu/resources/publications/324:open-access-n-european-universities-results-from-the-2016-2017-eua-institutional-survey.html.

${ }^{6}$ Crosier D., Kocanova D., Birch P., Davykovskaia O., Parveva T. Eurydice Brief. Modernisation of Higher Education in Europe: Academic Staff. 2017. P. 16. URL : https://eacea.ec.europa.eu/national-policies/eurydice/content/modernisation-higher-education-europe-academic-staff\%E2\%80\%93-2017 en.

${ }^{7}$ Final Draft 6 of the Rome Ministerial Communiqué. URL: http://www.ehea.info/Upload/BFUG DE UK 739 Draft 6 Rome Communique.pdf.

${ }^{8}$ Final Draft 6 of the Rome Ministerial Communiqué. P. $4 . \quad$ URL: http://www.ehea.info/Upload/BFUG DE UK 739 Draft 6 Rome Communique.pdf.
} 


\section{Аналіз законодавчих і нормативних документів з проблеми дослідження}

Проблема оцінювання і розвитку наукової діяльності НПП є актуальною для національного освітнього та наукового просторів і регламентується відповідними законодавчими та нормативно-правовими документами. Зокрема:

Законом України «Про освіту», згідно з яким є одним із складників ${ }^{9}$ :

- внутрішньої системи забезпечення якості освіти через «оприлюднені критерії, правила і процедури оцінювання науково-педагогічної діяльності науково-педагогічних працівників» (стаття 41);

- прав та обов'язків науково-педагогічних працівників і здійснення «справедливого та об'єктивного оцінювання своєї професійної діяльності»; підвищення кваліфікації, перепідготовки (стаття 54).

Законом України «Про вищу освіту», відповідно до якого ${ }^{10}$ :

- реалізується в рамках системи внутрішнього забезпечення якості вищої освіти через «щорічне оцінювання ... науково-педагогічних працівників закладу вищої освіти та регулярне оприлюднення результатів таких оцінювань на офіційному веб-сайті закладу вищої освіти, на інформаційних стендах та в будь-який інший спосіб», забезпечення підвищення кваліфікації науково-педагогічних працівників (стаття 16);

- відбувається запровадження рейтингового оцінювання здобутків науково-педагогічних працівників закладу вищої освіти (стаття 32).

Законом України «Про наукову і науково-технічну діяльність» у частині ${ }^{11}$ :

- атестації наукових працівників, що здійснюється «з метою встановлення «результативності його роботи; визначення відповідності його кваліфікації займаній посаді; виявлення перспективи використання його здібностей, стимулювання підвищення його професійного рівня; визначення потреби у підвищенні кваліфікації, його професійній підготовці» (стаття 29);

- забезпечення розвитку кадрового потенціалу шляхом: підготовки і підвищення кваліфікації, стажування, підготовки і перепідготовки, зокрема за межами України, забезпечення престижності наукової і науково-технічної діяльності, запровадження системи атестації наукових кадрів, сприяння визнанню документів про вищу освіту, наукових ступенів та вчених звань на міжнародному рівні (стаття 61).

Постановою Кабінету Міністрів України «Про затвердження Ліцензійних умов провадження освітньої діяльності» від 30 грудня 2015 р. № 1187 щодо кадрових вимог до забезпечення провадження освітньої діяльності у сфері вищої та післядипломної освіти для осіб з вищою освітою ${ }^{12}$.

Наказами Міністерства освіти і науки України, серед яких «Про державну атестацію закладів вищої освіти в частині провадження ними наукової (науково-технічної) діяльності» від 12 березня 2019 р. № $338^{13}$, зокрема крізь призму показників оцінки наукового потенціалу та результативності 3ВО, відомостей про наукові досягнення та перспективного плану розвитку 3 ВО.

Окремої уваги заслуговують результати незалежного міжнародного аудиту дослідницької та інноваційної системи України в рамках програми «Горизонт-2020» ${ }^{14}$. 3-поміж 30 рекомендацій комісії незалежних експертів та провідних фахівців профільних міністерств країн ЄС важливими є настанови щодо:

- стимулювання «дослідників до наукової кар'єри, використовуючи набір різних методологічних інструментів, таких, як збільшення заробітної плати, програми обміну чи виплати винагород» відповідно до їх наукової діяльності та одержаних результатів» ${ }^{15}$;

- гарантування університетами «реальних можливостей залучення до міжнародної системи науки,

\footnotetext{
9 Про освіту : Закон України від 05.09.2017 № 2145-VIII. URL : https://zakon.rada.gov.ua/laws/show/2145-19\#Text.

10 Про вищу освіту : Закон України від 01.07.2014 № 1556-VII. URL : https://zakon.rada.gov.ua/laws/show/1556-18\#Text.

11 Про наукову і науково-технічну діяльність : Закон України від 26.11.2015 № 848-VIII. URL : https://zakon.rada.gov.ua/laws/show/84819\#Text.

12 Про затвердження Ліцензійних умов провадження освітньої діяльності : постанова Кабінету Міністрів України від 30.12 .2015 № 1187. URL : https://zakon.rada.gov.ua/laws/show/1187-2015-n\#Text.

13 Про державну атестацію закладів вищої освіти в частині провадження ними наукової (науково-технічної) діяльності : наказ МОН України від 12.03.2019 № 338. URL : https://zakon.rada.gov.ua/laws/show/z0688-19\#Text.

14 Заключний звіт незалежного європейського аудиту національної системи досліджень та інновацій України. (2017). URL: https://op.europa.eu/mt/publication-detail/-/publication/adb1f077-dedc-11e6-ad7c-01aa75ed71a1/language-uk/format-PDF/source120740890 .

15 Заключний звіт незалежного європейського аудиту національної системи досліджень та інновацій України. (2017). C. 53. URL: https://op.europa.eu/mt/publication-detail/-/publication/adb1f077-dedc-11e6-ad7c-01aa75ed71a1/language-uk/format-PDF/source$\underline{120740890}$
} 
технологій та інноваційної діяльності з урахуванням їх внеску до наукового прогресу» 16.

В умовах сьогодення базовим орієнтиром, який визначає ключові кроки щодо підвищення ефективності наукової діяльності в університетах і посилення дослідницької функції НПП, є Дорожня карта інтеграції України до Європейського дослідницького простору (ERA-UA) ${ }^{17}$, схвалена у 2018 р. рішенням колегії МОН України. Одним із шести пріоритетів визначено «Відкритий ринок праці», згідно з яким передбачається реалізація чотирьох цілей, а саме про: створення стимулів для дослідників (ціль 1) ${ }^{18}$ стратегії для кар'єри молодого вченого (ціль 2) ${ }^{19}$, удосконалення законодавства щодо мобільності українських вчених (ціль 3) ${ }^{20}$ і найму дослідників» (ціль 4) ${ }^{21}$. Наскрізною ідеєю, яка становить підґрунтя імплементації наведених цілей, $€$ об'єктивне оцінювання дослідницької діяльності вчених на основі вдосконалених відповідних інструментів, що дасть змогу успішному професійному просуванню та визнанню дослідницької діяльності НПП у суспільстві.

Про значущість дослідницької діяльності НПП і оцінювання їх діяльності засвідчують результати загальнонаціонального опитування академічного персоналу 37 ЗВО України, яке проводилося вченими Інституту вищої освіти НАПН України у 2019 році ${ }^{22}$. Згідно з наведеними результатами 61 \% викладачів вважає, що здійснення ними наукової діяльності $€$ одним із вагомих факторів впливу на підвищення якості вищої освіти 3ВО23 і підтверджує тезу про необхідність провадження високопрофесійного викладання на основі інноваційних досліджень. Крім того, майже 80 \% НПП вважають показник публікацій в авторитетних виданнях найважливішим при оцінюванні їх професійних досягнень і лише другим за значенням є показник щодо їх рейтингу у $3 \mathrm{BO}^{24}$, а також 42 \% викладачів зазначили, що саме за наявність таких статей у доробку вченого вони одержують премії у 3 ВО 25

Отже, попри інституційну автономію і наявність в університетах розроблених нормативних документів щодо оцінювання і розвитку дослідницької діяльності НПП, ця проблема є злободенною і посилилася також унаслідок світової пандемії COVID-19, що активізувало процес цифровізації в освітньому і науковому просторах. Крім того, виклики, зумовлені, з одного боку, вимогами відкритої науки і відкритого доступу до результатів досліджень вчених, з іншого - зростанням запитів до оцінювання наукової діяльності, потребують негайного вирішення з огляду на перспективи наукового потенціалу вчених і підвищення ефективності їх діяльності та впливу діяльності університетів на суспільство.

\footnotetext{
16 Заключний звіт незалежного європейського аудиту національної системи досліджень та інновацій України. (2017). C. 58. URL: https://op.europa.eu/mt/publication-detail/-/publication/adb1f077-dedc-11e6-ad7c-01aa75ed71a1/language-uk/format-PDF/source120740890 .

17 Дорожня карта інтеграції України до Європейського дослідницького простору (ERA-UA), схвалена рішенням колегії Міністерства освіти і науки України, протокол від 22.03.2018 № 3/1-7. URL : https://mon.gov.ua/storage/app/media/kolegiya-ministerstva/2018/05/1dorozhnya-karta-integratsii-ukraini-do-evro.pdf.

18 Дорожня карта інтеграції України до Європейського дослідницького простору (ERA-UA), схвалена рішенням колегії Міністерства освіти і науки України, протокол від 22.03.2018 № 3/1-7. C. 14. URL: https://mon.gov.ua/storage/app/media/kolegiyaministerstva/2018/05/1-dorozhnya-karta-integratsii-ukraini-do-evro.pdf.

${ }_{19}$ Дорожня карта інтеграції України до Європейського дослідницького простору (ERA-UA), схвалена рішенням колегії Міністерства освіти і науки України, протокол від 22.03.2018 № 3/1-7. C. 15. URL: https://mon.gov.ua/storage/app/media/kolegiyaministerstva/2018/05/1-dorozhnya-karta-integratsii-ukraini-do-evro.pdf.

20 Дорожня карта інтеграції України до Європейського дослідницького простору (ERA-UA), схвалена рішенням колегії Міністерства освіти і науки України, протокол від 22.03.2018 № 3/1-7. C. 16. URL: https://mon.gov.ua/storage/app/media/kolegiyaministerstva/2018/05/1-dorozhnya-karta-integratsii-ukraini-do-evro.pdf.

21 Дорожня карта інтеграції України до Європейського дослідницького простору (ERA-UA), схвалена рішенням колегії Міністерства освіти і науки України, протокол від 22.03.2018 № 3/1-7. C. 17. URL: https://mon.gov.ua/storage/app/media/kolegiyaministerstva/2018/05/1-dorozhnya-karta-integratsii-ukraini-do-evro.pdf.

22 Результати загальнонаціонального опитування «Перспективи та потреби розвитку університетів України у процесі реформування вищої освіти у контексті європейської інтеграції» / авт. кол. Київ : Інститут вищої освіти НАПН України, 2019. 77 с. Університети і лідерство. 2019. № 2 (8). C. 144-220. DOI: https://doi.org/10.31874/2520-6702-2019-8-2-144-220.

${ }_{23}$ Результати загальнонаціонального опитування «Перспективи та потреби розвитку університетів України у процесі реформування вищої освіти у контексті європейської інтеграції» / авт. кол. Київ: Інститут вищої освіти НАПН України, 2019. 77 с. Університети і лідерство. 2019. № 2 (8). С. 144-220. C. 186. DOI: https://doi.org/10.31874/2520-6702-2019-8-2-144-220.

24 Результати загальнонаціонального опитування «Перспективи та потреби розвитку університетів України у процесі реформування вищої освіти у контексті європейської інтеграції» / авт. кол. Київ : Інститут вищої освіти НАПН України, 2019. 77 с. Університети і лідерство. 2019. № 2 (8). С. 144-220. C. 172. DOI: https://doi.org/10.31874/2520-6702-2019-8-2-144-220.

25 Результати загальнонаціонального опитування «Перспективи та потреби розвитку університетів України у процесі реформування вищої освіти у контексті європейської інтеграції» / авт. кол. Київ : Інститут вищої освіти НАПН України, 2019. 77 с. Університети і лідерство. 2019. № 2 (8). C. 144-220. C. 208. DOI: https://doi.org/10.31874/2520-6702-2019-8-2-144-220.
} 


\section{Аналіз вітчизняних і зарубіжних публікацій з проблеми дослідження}

Проведений аналіз зарубіжних наукових джерел дає підстави для висновку, що проблемі оцінювання і розвитку дослідницької діяльності академічного персоналу університетів приділено багато уваги, і дискусії розгортаються не тільки на рівні окремих вчених, чи конференцій, така проблема є предметом обговорення в Європейській комісії, Асоціації Європейських Університетів і Європейського дослідницького простору тощо. Так, у рамках ініціативи Open Science ${ }^{26}$ комісією ЄС представлено (2019р.) прагнення (ambitions) щодо діяльності Європейської хмари відкритої науки та ключові напрями реалізації з 2021 p. Horizon Europe, 3поміж яких приділено увагу дослідницькій діяльності академічного персоналу, а саме необхідність ${ }^{27}$ :

- вдосконалення системи нагород та заохочень за проведену наукову роботу, в якій оцінювання професійної діяльності вченого провадиться з урахуванням його відкритої дослідницької роботи;

- володіння дослідниками Європи професійними навичками і забезпечення їх необхідною підтримкою для імплементації відкритої науки та практики.

Одним з перших кроків у прагненні Асоціації Європейських Університетів щодо розширення знань та підтримки європейських університетів у вирішенні питань з ключових концепцій, проблем та учасників, які беруть участь в оцінюванні наукових досліджень та вчених, є рекомендації B. Saenen, L. Borrell-Damián ${ }^{28}$. Ключова ідея рекомендацій полягає у запровадженні нового підходу, зокрема в оцінюванні дослідників із метою забезпечення відповідності системи оцінки тим якостям, які вимагає Open Science. Оцінювання повинно здійснюватися на основі декількох критеріїв, а не лише за результатами цифрових показників факторів впливу журналів, і залишатися відповідним механізмом для досягнення поставленої мети та запровадження стимулів і винагороди всіх виконавців дослідження відповідно до їх внеску ${ }^{29}$. Вдосконалення інструментів оцінювання дослідників є спільною відповідальністю і вимагає узгоджених підходів, що об'єднує основних суб'єктів цього процесу.

Оцінювання дослідників та їх розвиток висвітлюється у площині гендерного підходу, передусім у процесі відбору грантових проєктів, оскільки їх виконання набуває особливої актуальності для кар'єри дослідників. Установлено, що у світовому науковому просторі $€$ достатньо доказів, що жінки мають нижчий рівень успіху, незважаючи на отримання, в окремих випадках, більше грантів у деяких наукових галузях ${ }^{30}$. Гендерна упередженість простежується саме на етапі експертного оцінювання грантів. Зокрема, ще починаючи з 1997 року доведено, що жінки-дослідниці, які подають заявку на участь у грантових проєктах, мають бути в 2,5 рази ефективнішими, ніж чоловіки, щоб отримати однаковий бал. У таких випадках саме показники ефективності, за допомогою яких оцінюються грантові проєкти, потребують коригування, оскільки вони можуть бути гендерно упередженими і віддзеркалювати, з одного боку, дисбаланс дослідницької системи загалом, з іншого - нерівні ієрархічні позиції з неоднаковими ресурсами.

Наукова досконалість і їі релевантність, представлення використання дослідницьких елементів для досягнення досконалості у навчанні здобувачів вищої освіти належать до критеріїв Європейської премії за досконалість у викладанні соціальних та гуманітарних наук, яку присуджує 32011 року Центральноєвропейський університет ${ }^{31}$.

Загалом можна виділити такі напрями дослідницького пошуку:

- структура оцінювання вчених у контексті відкритої науки і відкритого доступу (B. Saenen, R. Morais, V. Gaillard, L. Borrell-Damián, (2019) ${ }^{32}$ тощо;

- використання альтернативних метрик в оцінюванні дослідників (A. Togia, E. Koseoglou, S. Zapounidou) ${ }^{33}$ тощо;

\footnotetext{
${ }^{26}$ Open Science / European Commission ; Dec. 13, 2020. URL : https://ec.europa.eu/info/files/open-science_en.

27 Open Science / European Commission. URL : https://ec.europa.eu/info/sites/info/files/research and innovation/knowledge publications tools and data/documents/ec rtd factsheet-open-science 2019.pdf.

28 Saenen B., Borrell-Damián L. Reflections on University Research Assessment: key concepts, issues and actors. (2019). URL: https://eua.eu/resources/publications/825:reflections-on-university-research-assessment-key-concepts,-issues-and-actors.html.

${ }^{29}$ Saenen B., Borrell-Damián L. Reflections on University Research Assessment: key concepts, issues and actors. (2019). P. 4. URL: https://eua.eu/resources/publications/825:reflections-on-university-research-assessment-key-concepts,-issues-and-actors.html.

30 Schiffbänker H. Grant allocation and gender disparity: identifying the bias factors. URL : https://eua.eu/resources/expert-voices/154:grantallocation-and-gender-disparity-identifying-the-bias-factors.html.

${ }^{31}$ Центральноєвропейський університет. URL : https://ctl.ceu.edu/call-applicationsnominations

32 Saenen B., Morais R., Gaillard V., Borrell-Damián L. Research Assessment in the Transition to Open Science. (2019). URL: https://eua.eu/resources/publications/888:research-assessment-in-the-transition-to-open-science.html.

${ }^{33}$ Togia A., Koseoglou E., Zapounidou S. Alternative Metrics for the Evaluation of Scholarly Activities: An Analysis of Articles Authored by
} 
- вдосконалення діяльності академічного персоналу, зокрема дослідницької (D. Crosier, D. Kocanova, P. Birch, O. Davykovskaia, T. Parveva, (2017) ${ }^{34}$ тощо;

- розроблення моделі оцінювання (P.I.Darroch, L.H.Colledge, (2016) $)^{35}$ і компетентності (M. Blaškováa, R. Blaškoa, A. Kucharbíková, (2014) ${ }^{36}$; (S. Kobayashi, J. Dolin, A. Søborg, J. Turner (2017) ${ }^{37}$ дослідників тощо;

- оцінювання дослідницької діяльності викладачів як гендерна проблема (S. E. Kalpazidou et. al., (2018) ${ }^{38} ;$ ( H. Schiffbänker, (2020) ${ }^{39}$ тощо;

- вплив публічного оцінювання університетських досліджень на оплату праці академічного персоналу (G .De Fraja, G. Facchini, J. Gathergood) ${ }^{40}$;

- добір академічного персоналу (N. Bhalla, M. Welch) ${ }^{41}$, зокрема дослідників в країнах $\in C$ (Хорватії ${ }^{42}$, Бельгії ${ }^{43}$ тощо);

- академічний розвиток викладачів (E. Brogt ${ }^{44}$, C. Nerantzi, G. Chatzidamianos ${ }^{45}$, J. Angermuller $\left.{ }^{46}\right)$.

Проблему оцінювання наукової діяльності НПП і їх розвитку всебічно представлено в працях вітчизняних вчених, що дає змогу виокремити такі напрями досліджень:

- - науково-дослідницька діяльність суб'єктів освітнього процесу університетів (О.Г. Ярошенко і Ю.А. Скиба 47);

- управління науково-дослідницькою діяльністю у ЗВО України (Ю.А. Скиба $\left.{ }^{48}\right)$;

- кар'єрний (Г.П. Чорнойван $\left.{ }^{49}\right)$, професійний (Т.А. Борова ${ }^{50}$, О.В. Жабенко ${ }^{51}$, С.А. Калашнікова ${ }^{52}$,

Greek

Researchers

URL :

https://www.academia.edu/33686475/Alternative Metrics for the Evaluation of Scholarly Activities An Analysis of

Articles Authored by Greek Researchers.

${ }^{34}$ Crosier D., Kocanova D., Birch P., Davykovskaia O., Parveva T. Eurydice Brief. Modernisation of Higher Education in Europe: Academic Staff. 2017. P. 4. URL: https://eacea.ec.europa.eu/national-policies/eurydice/content/modernisation-higher-education-europe-academic-staff\%E2\%80\%93-2017 en.

35 Darroch P.I., Colledge L.H. Using research metrics responsibly and effectively as a researcher. Infozine. 2016. Special Issue 1. P. 23-24. DOI : https://doi.org/10.3929/ethz-a-010744984.

36 Blaškováa M., Blaškoa R., Kucharpíková A. Competences and Competence Model of University Teachers. Procedia - Social and Behavioral Sciences. 2014. № 159. P. 457-467.

${ }^{37}$ Kobayashi S., Dolin J., Søborg A., Turner J. (2017). Building Academic Staff Teaching Competencies: How Pedagogic Continuous Professional Development for Academic Staff Can Be Organised and Developed in Research-Intensive Universitie. DOI : https://doi.org/10.1007/978-3319-56499-9 5

${ }^{38}$ Kalpazidou S.E., Bührer S., Schraudner M., Reidl S., Müller J., Palmen R., Haase S., Graversen E.K., Holzinger F., Striebing C., Groó D., Klein S., Rigler D., Høg U.E. A Conceptual Evaluation Framework for Promoting Gender Equality in and Innovation. URL: https://www.ucviden.dk/en/publications/a-conceptual-evaluation-framework-for-promoting-gender-equality-i.

${ }_{39}$ Schiffbänker H. Grant allocation and gender disparity: identifying the bias factors. URL : https://eua.eu/resources/expert-voices/154:grantallocation-and-gender-disparity-identifying-the-bias-factors.html.

${ }^{40}$ De Fraja G., Facchini G., Gathergood J. Academic salaries and public evaluation of university research: Evidence from the UK Research Excellence Framework. Economic Policy. 2019. Vol. 34. Issue 99. P. 523-583. URL : https://doi.org/10.1093/epolic/eiz009.

${ }^{41}$ Bhalla N., Welch M. Strategies to improve equity in faculty hiring. 2019. DOI : https://doi.org/10.1091/mbc.E19-08-0476.

42 Sušanj Z., Jakopec A., Đorić A. Academics' effectiveness and professional development in Croatia: Challenges for human resource management in higher education institutions. 2020. DOI : https://doi.org/10.1111/ejed.12422.

${ }^{43}$ Royal Academy of Overseas Sciences. Evaluating researchers and research teams. URL : http://www.guidelines.kaowarsom.be/home.

${ }^{44}$ Brogt E. Engaging with different professional recognition and development opportunities for academic developers. International Journal for Academic Development. 2020. DOI : https://doi.org/10.1080/1360144X.2020.1840380.

${ }^{45}$ Nerantzi C., Chatzidamianos G. Reflecting on Academic Development: A Dialogue About A FLEXible Journey. International Journal of Management and Applied Research. 2018. Vol. 5. No 2. P. 55-68. DOI : https://doi.org/10.18646/2056.52.18-005.

${ }^{46}$ Angermuller J. Academic careers and the valuation of academics. A discursive perspective on status categories and academic salaries in France as compared to the U.S., Germany and Great Britain. High Education. 2017. № 73. P. 963-980. DOI : https://doi.org/10.1007/s10734017-0117-1.

47 Ярошенко О.Г., Скиба Ю.А. Концепція реалізації науково-дослідницької діяльності суб'єктів освітнього процесу університетів. Концепція та методологія реалізації науково-дослідницької діяльності суб'єктів навчально-виховного прочесу університетів : монографія / авт. кол. К.: Інститут вищої освіти НАПН України, 2016. 178 с. С. 27-29. URL: https://ihed.org.ua/wpcontent/uploads/2018/09/mon.-Konc-ta-metod-nauk-dosl diyaln-subyektiv-Univs IVO-NAPN-2016-178s.pdf.

${ }^{48}$ Скиба Ю.А. Порівняльний аналіз управління науково-дослідницькою діяльністю у вищих навчальних закладах України (остання чверть XX ст. і початок XXI ст.). Концепція та методологія реалізації науково-дослідницької діяльності суб'єктів навчальновиховного процесу університетів : монографія / авт. кол. К. : Інститут вищої освіти HAПН України, 2016. 178 с. С. 45-52. URL : https://ihed.org.ua/wp-content/uploads/2018/09/mon.-Konc-ta-metod-nauk-dosl diyaln-subyektiv-Univs IVO-NAPN-2016-178s.pdf.

49 Чорнойван Г.П. Механізми розвитку кар'єри дослідника в системі вищої освіти України у світлі інтеграції до Європейського дослідницького простору. Концепція та методологія реалізації науково-дослідницької діяльності суб'єктів навчально-виховного прочесу університетів : монографія / авт. кол. К. : Інститут вищої освіти HAПН України, 2016. 178 с. С. 122-138. URL: 
Л.М. Петренко $\left.{ }^{53}\right)$, розвиток дослідника в системі вищої освіти України та за рубежем, зокрема підвищення кваліфікації (О.В. Старостіна $\left.{ }^{54}\right)$;

- професійний профіль НПП різних професійних рівнів у дослідницькій діяльності $\left(Ю . А\right.$. Скиба ${ }^{55}$;

- розвиток дослідницької (С.О. Сисоєва і Л.В. Козак ${ }^{56}$, О.Г. Ярошенко ${ }^{57}$, інші ${ }^{58}$ ), іншомовної (Н. Дівінська $\left.{ }^{59}\right)$, ціннісної (І.Ю. Регейло $\left.{ }^{60}\right)$, компетентності НПП;

- оцінювання наукової діяльності НПП (І.М. Грищенко ${ }^{61}$, Ю.В. Андрашко, А.О. Білошицький, О.Ю. Кучанський, С.В. Білошицька, Т.О. Лященко ${ }^{62}$ ).

Отже у зарубіжному науковому просторі проблема оцінювання та розвитку дослідницької діяльності вченого $є$ особливо актуальною, що зумовлено передусім ініціативою «Відкритої науки» та відкритого доступу, новим проєктом Horizon Europe, а також нового змісту набуло вивчення гендерного підходу. У працях вітчизняних вчених оцінювання розглядається здебільшого як складник внутрішньої системи забезпечення якості вищої освіти та управління науковою діяльністю НПП.

https://ihed.org.ua/wp-content/uploads/2018/09/mon.-Konc-ta-metod-nauk-dosI_diyaln-subyektiv-Univs_IVO-NAPN-2016-178s.pdf.

50 Борова Т.А. Створення системи професійного розвитку науково-педагогічних працівників вищого навчального закладу на засадах адаптивного управління. Педагогіка і психологія та медико-біологічні проблеми фізичного виховання і спорту. 2012. № 3. С. 16-20. URL : https://www.sportpedagogy.org.ua/html/journal/2012-03/12btaamp.pdf.

51 Жабенко О.В. Професійний розвиток науково-педагогічних працівників університетів в умовах інтеграції вищої освіти і науки: моделі і технологія. Теоретичні основи і технологія професійного розвитку науково-педагогічних працівників університетів в умовах інтеграції вищої освіти і науки : монографія / авт. кол. К. : Інститут вищої освіти HAПН України, 2019. 236 с. C. 40-83. URL : https://ihed.org.ua/wp-content/uploads/2020/04/Tehnologiya_prof_rozvitku_pracivn_VNZ_Monogr_IVO-2019-236p_avtors-kolektiv.pdf.

52 Калашнікова С. Професійний розвиток керівників вищих навчальних закладів: аналіз провідного зарубіжного досвіду. Проблеми освіти. 2013. № 74. 4. 1. С. 11-22.

53 Петренко Л.М. Стратегічні орієнтири професійного розвитку науково-педагогічних працівників в умовах відкритої освіти. 2020. DOI : https://doi.org/10.32405/2218-7650-2020-13(42)-170-184.

${ }^{54}$ Старостіна О.В. Досвід підвищення кваліфікації викладачів вищої школи у Великій Британії. 2020. https://doi.org/10.26661/2522-4360-2020-1-55.

${ }^{55}$ Скиба Ю.А. Професійний профіль і кваліфікаційні рівні науково-педагогічних працівників університетів в умовах інтеграції вищої освіти і наук. Теоретичні основи і технологія професійного розвитку науково-педагогічних працівників університетів в умовах інтеграції вищої освіти і науки : монографія / авт. кол. К. : Інститут вищої освіти HAПН України, 2019. 236 с. С. 4-39. URL: https://ihed.org.ua/wp-content/uploads/2020/04/Tehnologiva prof rozvitku pracivn VNZ Monogr IVO-2019-236p avtors-kolektiv.pdf.

${ }^{56}$ Сисоєва С.О., Козак Л.В. Дослідницька компетентність викладача вищої школи: програма розвитку. Неперервна професійна освіта: теорія і практика. 2016. Вип. 1-2. С. 39-44. С. 40. URL : http://nbuv.gov.ua/UJRN/NPO_2016_1-2_9.

57 Ярошенко О.Г. Теоретичні основи і технологія розвитку дослідницької компетентності науково-педагогічних працівників в умовах інтеграції вищої освіти і науки. Теоретичні основи і технологія професійного розвитку науково-педагогічних працівників університетів в умовах інтеграції вищої освіти і науки : монографія / авт. кол. К. : Інститут вищої освіти HAПН України, 2019. 236 с. С. 110-146. URL : https://ihed.org.ua/wp-content/uploads/2020/04/Tehnologiya prof rozvitku pracivn VNZ Monogr IVO-2019-236p avtors-kolektiv.pdf.

58 Професійно-педагогічна компетентність викладача вищого навчального закладу : навч. посіб. / за ред. І.Л. Холковської. Вінниця : ТОВ «Нілан ЛТД», 2017. 144 с. С. 37.

59 Дівінська Н. Теоретичні основи і модель розвитку іншомовної компетентності науково-педагогічного працівника. Теоретичні основи і технологія професійного розвитку науково-педагогічних працівників університетів в умовах інтеграції вищої освіти і науки : монографія / авт. кол. К. : Інститут вищої освіти НАПН України, 2019. 236 с. С. 147-162. URL: https://ihed.org.ua/wpcontent/uploads/2020/04/Tehnologiya_prof rozvitku pracivn_VNZ Monogr_IVO-2019-236p_avtors-kolektiv.pdf.

60 Регейло І.Ю. Розвиток ціннісної компетентності науково-педагогічних працівників університетів в умовах інтеграції вищої освіти і науки. Теоретичні основи і технологія професійного розвитку науково-педагогічних працівників університетів в умовах інтеграції вищої освіти і науки : монографія / авт. кол. К. : Інститут вищої освіти НАПН України, 2019. 236 с. С.163-225. URL: https://ihed.org.ua/wp-content/uploads/2020/04/Tehnologiya_prof rozvitku_pracivn_VNZ Monogr_IVO-2019-236p_avtors-kolektiv.pdf.

61 Грищенко І.М. Оцінювання ефективності діяльності науково-педагогічних працівників вищого навчального закладу. Trends and mechanisms providing economic security of European education under the conditions of globalization : collective scientific monograph / under the editing I.M. Gryshchenko, I.O. Tarasenko, A.O. Kasych, M.I. Skrypnyk. Agharta Science Publishing House, Szczecin, Poland, 2018. P. $250-264$.

62 Білощицький А.О., Кучанський О.Ю., Андрашко Ю.В., Білощицька С.В., Лященко Т.О. Управління розвитком складних систем. 2017. № 29. С. 151-159. 


\section{Поняттєво-термінологічний апарат проблеми оцінювання і розвитку НПП щодо їх наукової діяльності}

Всебічне висвітлення означеної проблеми передбачає насамперед визначення сутності ключових термінів: «оцінювання», «наукова / дослідницька діяльність», «науково-педагогічний працівник», «дослідник».

У країнах ЄС викладачів / дослідників диференціюють відповідно до таких ознак: основної діяльності, до якої віднесено викладання і дослідження, лише викладання чи лише дослідження; відповідно до закладу освіти, в якому вони працюють (університет чи інший ЗВО); контрактного статусу (умовами роботи на постійній основі - строковому контракті, або невизначений, у рамках виконання певних повноважень) тощо ${ }^{63}$. У нашому науковому пошуку «дослідник» вживається відповідно до Керівництва Фраскаті (Frascati Manual) згідно з яким ${ }^{64}$ "це професіонали, які працюють у сфері розроблення або створення нового знання, проводять дослідження, вдосконалюють або розробляють концепції, теорії, моделі, технічні засоби, програмне забезпечення, а також працюють у сфері управління такими проєктами».

В Україні науково-педагогічні працівники - це вчені, які «за основним місцем роботи у закладах вищої освіти провадять навчальну, методичну, наукову (науково-технічну, мистецьку) та організаційну діяльність» (стаття 53) ${ }^{65}$ і саме «дослідницько-інноваційний складник теоретично відрізняє» їх від інших працівників і «практично відокремлює університети, які орієнтовані на розвиток і творення нового» ${ }^{66}$ від інших 3 ВО, які такої діяльності не здійснюють. До переліку посад (професій) НПП віднесено: «професор», «доцент», «викладач закладу вищої освіти», «старший викладач», «асистент» ${ }^{67}$.

Однією із функцій, яку зобов'язаний виконувати НПП, $є$ наукова (дослідницька) діяльність, що визначається як «інтелектуальна творча діяльність, спрямована на одержання нових знань та (або) пошук шляхів їх застосування, основними видами якої $€$ фундаментальні та прикладні наукові дослідження» (стаття 1) ${ }^{68}$. Водночас НПП не лише здійснюють дослідницьку роботу. Оскільки вони співвіднесені до посад наукових працівників (стаття 37) ${ }^{69}$, то «провадять наукову, науково-технічну, науково-організаційну, науковопедагогічну діяльність» (стаття 1$)^{70}$ ). Зокрема, науково-організаційна робота - «діяльність, спрямована на методичне, організаційне забезпечення та координацію наукової, науково-технічної та науково-педагогічної діяльності» (стаття 1) ${ }^{71}$; науково-педагогічна робота - «педагогічна діяльність в університетах, академіях, інститутах та закладах післядипломної освіти, що пов'язана з науковою та (або) науково-технічною діяльністю» (стаття 1) ${ }^{72}$; науково-технічна робота - «наукова діяльність, спрямована на одержання і використання нових знань для розв'язання технологічних, інженерних, економічних, соціальних та гуманітарних проблем, основними видами якої $€$ прикладні наукові дослідження та науково-технічні (експериментальні) розробки» (стаття 1) ${ }^{73}$.

Незважаючи на розмаїття наукової діяльності, НПП перевантажені обсягами викладацької функції і збалансованого дотримання дуальності «наукової» і «педагогічної» діяльності не відбувається ${ }^{74}$. Крім того, зменшена за часткою наукова робота ускладнюється іншими чинниками, з-поміж яких різке посилення цифровізації, що зумовлено світовою пандемією COVID-19, застаріла дослідницька інфраструктура,

\footnotetext{
${ }^{63}$ Crosier D., Kocanova D., Birch P., Davykovskaia O., Parveva T. Eurydice Brief. Modernisation of Higher Education in Europe: Academic Staff. 2017. P.4. URL: https://eacea.ec.europa.eu/national-policies/eurydice/content/modernisation-higher-education-europe-academic-staff\%E2\%80\%93-2017 en.

${ }^{64}$ Frascati Manual 2015: Guidelines for Collecting and Reporting Data on Research and Experimental Development. The Measurement of Scientific, Technological and Innovation Activities. Glossary of Terms. 2015. P. 379. URL: https://www.oecd-ilibrary.org/docserver/ 9789264239012-en.pdf?expires=1548749491\&id=id\&accname=guest\&checksum=E65709A4CF0F7B345FE93B662A7229E3.

65 Про вищу освіту : Закон України від 01.07.2014 № 1556-VII. Ст. 53. URL : https://zakon.rada.gov.ua/laws/show/1556-18\#Text.

66 Луговий В.І., Слюсаренко О.М., Таланова Ж.В. Реалізація дослідницько-інноваційного потенціалу університетів як невід’ємного складника їх діяльності. Наука та наукознавство. 2019. .№ 3 (105). С. 26-45. С. 29.

67 Національний класифікатор України. ДК 003:2010. Про затвердження, внесення зміни та скасування нормативних документів : наказ Держспоживстандарту України від 28.07.2010 № 327. URL : https://zakon.rada.gov.ua/rada/show/v0327609-10\#Text.

68 Про наукову і науково-технічну діяльність : Закон України від 26.11.2015 № 848-VIII. URL : https://zakon.rada.gov.ua/laws/show/848-19\#Text.

69 Про наукову і науково-технічну діяльність : Закон України від 26.11.2015 № 848-VIII. URL : https://zakon.rada.gov.ua/laws/show/848-19\#Text.

70 Про наукову і науково-технічну діяльність : Закон України від 26.11.2015 № 848-VIII. URL : https://zakon.rada.gov.ua/laws/show/848-19\#Text.

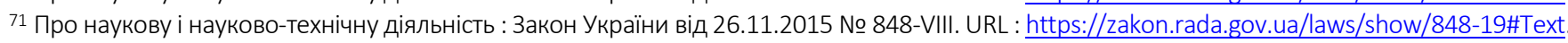

72 Про наукову і науково-технічну діяльність : Закон України від 26.11.2015 № 848-VIII. URL : https://zakon.rada.gov.ua/laws/show/848-19\#Text.

73 Про наукову і науково-технічну діяльність : Закон України від 26.11.2015 № 848-VIII. URL: https://zakon.rada.gov.ua/laws/show/848-19\#Text.

74 Луговий В.І. Реалізація науково-педагогічної функції викладача в контексті стратегії розвитку вищої освіти в Україні. Вісник Національної академії педагогічних наук України. 2020. № 2 (2). DOI : https://doi.org/10.37472/2707-305X-2020-2-2-11-3.
} 
неконкурентоспроможна оплата праці ${ }^{75}$ тощо.

Щодо дефеніції «оцінювання», то в цілому це «визначення якості, цінності кого-, чого-небудь; складення уявлення, висновку про кого-, що-небудь, встановлення суті, значення, ролі тощо чогось, розуміння і визнання позитивних якостей, цінності кого-, чого-небудь» ${ }^{76}$. Натомість заслуговують на увагу визначення на основі теорії оцінювання в освітній системі B. Bell і J. Gilbert ${ }^{77}$, які запропонували два підходи, що були розгорнуто представлено у багатьох зарубіжних ${ }^{78}$ і вітчизняних ${ }^{79} 80$ дослідженнях, а саме:

- «оцінювання (assessment) - це процес оперування (систематизація, аналіз, узагальнення тощо) чисельними показниками, які виміряні відповідно до певних правил ${ }^{81 ; 82 ; 83}$;

- «оцінювання (evaluation) - це процес формулювання висновків на основі порівняння кількісних показників, отриманих із різних джерел, зі стандартами» $84 ; 85 ; 86$.

Необхідно також враховувати особливості між дефініціями «оцінювання» і «рейтингування», відмінність яких полягає у поставлених цілях. Так, ціль оцінювання (evaluation) полягає у дотриманні вимог стандартів, ціль рейтингування - визначення найкращих ${ }^{87}$.

Отже узагальнюючи наведену теорію для нашого наукового пошуку, можна стверджувати, що, поперше, оцінювання (evaluation) наукової діяльності - це встановлення відповідності наукової діяльності нПП вимогам стандарту на посаду («професора», «доцента», «викладача закладу вищої освіти», «старшого викладача», «асистента»). Утім нині такі стандарти ще не затверджено, незважаючи на проведене у січні 2020 року МОН України громадське обговорення професійного стандарту згаданих посад ${ }^{88}$. По-друге, оцінювання не лише важливий інструмент для підзвітності про здобуті результати НПП, але дає змогу визначити сильні і слабкі сторони проведеної наукової діяльності та є потужним стимулом і підґрунтям для визначення дослідницької перспективи і професійного зростання. Водночас наведене визначення потребує доповнення з огляду концептуальні засади, що $є$ базовими для оцінювання наукової діяльності вченого університету в сучасних умовах.

\footnotetext{
75 Луговий В.І. Реалізація науково-педагогічної функції викладача в контексті стратегії розвитку вищої освіти в Україні. Вісник Начіональної академії педагогічних наук України. 2020. № 2 (2). DOI : https://doi.org/10.37472/2707-305X-2020-2-2-11-3.

76 Великий тлумачний словник сучасної української мови (з дод. і допов.) / уклад. і голов. ред. В.Т. Бусел. Київ,: Ірпінь : ВТФ «Перун», 2005. 1728 с. С. 871.

77 Bell B., Gilbert J. Teacher Development: A Model from Science Education. London - New York : Routledge Taylor\& Francis Group, 2004. $190 \mathrm{p}$.

${ }^{78}$ Hämäläinen K., Pehu S., Wahlén S. Institutional Evaluations in Europe. (2001) URL : https://enqa.eu/indirme/papers-andreports/workshopand-seminar/institutional.pdf.

79 Горошко А., Нарчинська Т., Озимок І., Тарнай В. Глосарій термінів з моніторингу та оцінювання / 2-е вид. Київ : Укр.асоціація оцінювання, 2016. 53 c. URL : http://www.ukreval.org/images/publikacii/glossary.pdf.

80 Таланова Ж. Міжнародний, національний та інституційний виміри запровадження механізмів оцінювання якості вищої освіти. Аналіз провідного вітчизняного та зарубіжного досвіду щодо оцінювання якості вищої освіти в умовах євроінтеграції: аналітичні матеріали (частина I) (препринт) / О. Воробйова, М. Дебич, І. Линьова, В. Луговий, О. Оржель, О. Слюсаренко, Ж. Таланова, К. Трима ; за ред. В. Лугового, Ж. Таланової. Київ: Ін-т вищої освіти НАПН України, 2018. 172 с. С. 24-52. URL: https://ihed.org.ua/wp-
} content/uploads/2019/08/Analiz ocinki VO v umovah internac ch1 analit IVO-2018-172p avtors-kolektiv.pdf.

81 Bell B., Gilbert J. Teacher Development: A Model from Science Education. London - New York : Routledge Taylor\& Francis Group, 2004. $190 \mathrm{p}$.

82 Bell B., Cowie B. Teacher development for formative assessment. Waikato Journal of Education. 2001. № 7. URL: https://researchcommons.waikato.ac.nz/bitstream/handle/10289/6265/Bell\%20teacher.pdf\%3Bsequence=1.

83 КравченкоГ.Ю. Адаптивне управління розвитком інститутів післядипломної педагогічної освіти в Україні : монографія. К. : Педагогічна думка, 2015. 300 с. С. 160.

${ }^{84}$ Bell B., Gilbert J. Teacher Development: A Model from Science Education. London - New York : Routledge Taylor\& Francis Group, 2004. $190 \mathrm{p}$.

85 Bell B., Cowie B. Teacher development for formative assessment. Waikato Journal of Education. 2001. № 7. URL : https://researchcommons.waikato.ac.nz/bitstream/handle/10289/6265/Bell\%20teacher.pdf\%3Bsequence=1.

86 КравченкоГ.Ю. Адаптивне управління розвитком інститутів післядипломної педагогічної освіти в Україні : монографія. К. : Педагогічна думка, 2015. 300 с. С. 160.

87 Таланова Ж. Міжнародний, національний та інституційний виміри запровадження механізмів оцінювання якості вищої освіти. Аналіз провідного вітчизняного та зарубіжного досвіду щодо оцінювання якості вищої освіти в умовах євроінтеграції: аналітичні матеріали (частина I) (препринт) / О. Воробйова, М. Дебич, І. Линьова, В. Луговий, О. Оржель, О. Слюсаренко, Ж. Таланова, К. Трима ; за ред. В.Лугового, Ж. Таланової. Київ: Ін-т вищої освіти НАПН України, 2018. 172 с. С. 30. URL: https://ihed.org.ua/wpcontent/uploads/2019/08/Analiz ocinki VO v umovah internac ch1 analit IVO-2018-172p avtors-kolektiv.pdf.

$88 \mathrm{MOH}$ України пропонує для громадського обговорення проєкт профстандарту на посади «асистент», «викладач», «старший викладач», «доцент», «професор». URL: https://mon.gov.ua/ua/news/mon-proponuye-dlya-gromadskogo-obgovorennya-proyektprofstandartu-na-posadi-asistent-vikladach-starshij-vikladach-docent-profesor. 


\section{Концептуальні засади оцінювання і розвитку дослідницької діяльності академічного персоналу}

Висвітлюючи оцінювання і розвиток дослідницької діяльності вчених, передусім варто звернути увагу на дві концепції, які, на нашу думку, є основоположними, широко обговорюються вченими і викликають неоднозначні дискусії в академічних колах.

Концепція бібліометрії і наукометрії. Першою $є$ концепція, що ґрунтується на засадах методології бібліометрії і наукометрії, засновниками якої були Derek J. de Solla Price, H. Small, B. Griffith ${ }^{89}$, E. Garfield ${ }^{90}$. Сутність цієї концепції полягає у використанні статистичних методів для аналізу книг, статей та інших публікацій, зокрема кількості цитувань, та визначення впливу наукових праць, наукових досліджень, діяльності вченого, журналів, видавництв тощо. Упродовж останніх десятиліть оцінювання здійснюється за результатами кількості опублікованих праць дослідника передусім у журналах, що входять до Scopus i Web of Science, кількості цитувань, що має вагоме значення не лише для кар'єрного просування і винагород академічного персоналу, але й істотно впливає на фінансове забезпечення дослідницьких грантів.

Застосування наукометричних показників стрімко поширилося в освітньому та науковому просторах, що забезпечило включення статистичних методів до рейтингу університетів, зокрема до Шанхайського peŭmингу (Academic Ranking of World Universities, ARWU) ${ }^{91}$, який вважається найвпливовішим міжнародним рейтингом ${ }^{9293}$. Так, ARWU використовує шість об'єктивних показників для ранжирування світових університетів, включаючи кількість випускників та співробітників, які отримують Нобелівські премії та медалі, кількість високоцитованих дослідників, обраних Clarivate Analytics, кількість статей, опублікованих у журналах Nature and Science, кількість статей, проіндексованих у Індекс цитування наук - розширений та індекс цитування соціальних наук, а також показники діяльності університету на душу населення. Щорічно ARWU класифікує понад 1800 університетів, і публікуються найкращі $100{ }^{94}$.

Водночас у сучасних умовах оцінювання дослідницької діяльності вченого набуло дискримінаційного характеру і провадиться під гаслом афоризму «опублікувати або загинути» («publish or perish») 95;96;97, що зумовлено тиском із боку адміністрації університетів (особливо дослідницьких) про необхідність постійного продукування наукових результатів і відповідних публікацій, особливо у разі одержання винагороди або кар'єрного просування. У зв'язку з цим постають ризики щодо:

- виникнення хибних позитивних наукових результатів, ураховуючи те, що високорейтингові журнали публікують здебільшого лише нові або дуже вагомі результати, натомість інші результати залишаються поза увагою. Це спонукає дослідників до публікації сумнівних висновків, неправдивих позитивних результатів та шахрайства (фальсифікату) і $є$ відвертим наміром нечесності ${ }^{98}$;

- унеможливлення в рамках відкритої науки і відкритого доступу відтворення здобутих результатів експериментальних досліджень та ї повторюваності, навіть зважаючи на негативні або нульові результати, що призводить до відсутності відображення точної науки. Як правило, такі результати досліджень не оприлюднюються у престижних журналах, незважаючи на те, що вони можуть бути потенційно важливими ${ }^{99}$;

\footnotetext{
${ }^{89}$ Crawford S. Derek John De Solla Price (1922-1983): The man and the contribution. Bulletin of the Medical Library Association. 1984. № 72 (2). P. 238-239. PMID 6375781.

90 Garfield E.The Agony and the Ecstasy-The History and Meaning of the Journal Impact Factor. International Congress on Peer Review and Biomedical Publication. Chicago. 2005. URL : http://www2.psych.utoronto.ca/users/psy3001/files/JCR.pdf.

${ }^{91}$ Academic Ranking of World Universities. URL : http://www.shanghairanking.com/aboutarwu.html.

${ }_{92}$ Academic Ranking of World Universities. URL : http://www.shanghairanking.com/aboutarwu.html.

93 Луговий В.І., Слюсаренко О.М., Таланова Ж.В. Моніторинг, мотивація, мобілізація задля конкурентоспроможності університетів України: механізми реалізації. Вісник Національної академії педагогічних наук України. $2020 . \quad$ № $2(2) . \quad$ DOI https://doi.org/10.37472/2707-305X-2020-2-2-13-1.

${ }_{94}^{4}$ Academic Ranking of World Universities. URL : http://www.shanghairanking.com/aboutarwu.html.

95 Lee I. Publish or perish: The myth and reality of academic publishing. Language Teaching. 2014. № 47 (2), P. 250-261. DOI: https://doi.org/10.1017/S0261444811000504.

96 Fanelli D. Do Pressures to Publish Increase Scientists' Bias? An Empirical Support from US States Data. 2010. PLOS ONE 5 (4): e10271. DOI : https://doi.org/10.1371/journal.pone.0010271.

97 Grimes D.R., Bauch C.T., loannidis J.P.A. Modelling science trustworthiness under publish or perish pressure. 2018. R.Soc.Open Sci. 5: 171511. DOI : http://dx.doi.org/10.1098/rsos.171511.

98 Grimes D.R., Bauch C.T., loannidis J.P.A. Modelling science trustworthiness under publish or perish pressure. 2018. P. 2. R.Soc.Open Sci. 5: 171511. DOI : $\underline{\text { http://dx.doi.org/10.1098/rsos.171511. }}$

99 Grimes D.R., Bauch C.T., loannidis J.P.A. Modelling science trustworthiness under publish or perish pressure. 2018. P. 3. R.oc.Open Sci. 5: 171511. DOI : http://dx.doi.org/10.1098/rsos.171511.
} 
- руйнування довіри громадськості і суспільства до наукових досягнень учених ${ }^{100}$, що особливо $€$ істотним в умовах світової пандемії внаслідок CORONA-19;

- професійного вигорання дослідників, стресових ситуацій, що негативно впливає на якість наукових досліджень тощо ${ }^{101}$.

Із метою усунення наведених вище труднощів, D.R. Grimes, C.T. Bauch, J.P.A. loannidis ${ }^{102}$ розробили модель «надійності науки» на основі формули (рівняння) з використанням даних програмного забезпечення Publish or Perish ${ }^{103}$ (програма для виконання бібліометричного дослідження). До ключових показників формули входять дані про ${ }^{104}$ :

- вчених, розподілених на три категорії: «старанна спільнота» (дослідники, які сумлінно виконують експерименти і не маніпулюють результатами), «недбала спільнота» (дослідники, які не фальсифікують результати, але є неретельними і можуть мати сумнівну практику), «неетична спільнота» (дослідники, які деколи маніпулюють даними або свідомо подають сумнівні результати із швидкістю, що перевищує загальну кількість відкриттів);

- загальний обсяг доступного фінансування наукових досліджень;

- загальний коефіцієнт відкриття в конкретній галузі, який включає частку позитивних / значущих результатів, частку хибнопозитивних результатів і частку нульових результатів, а також швидкість подання вченими наукових результатів.

Заповнюючи відповідну формулу, встановлюється середня норма публікацій на одиницю фінансування за одиницю часу в рейтингових журналах і визначається відповідна категорія дослідників.

Програму Publish or Perish ${ }^{105}$ представлено в інформаційному просторі України, що дає змогу виконати на підставі даних Google Scholar (у статтях, монографіях, авторефератах, дисертаціях, звітах, матеріалах конференцій тощо) пошук відповідно до трьох режимів ${ }^{106}$.

Безперечно бібліометричний підхід $€$ важливим у визначенні успішності та впливовості діяльності дослідника, утім, на нашу думку, не повною мірою відображає наукову діяльність вченого і не дає підстав для всебічного та об'єктивного оцінювання його здобутків і визначення відповідного професійного розвитку.

Концепція досконалості. Заслуговує на увагу інша система поглядів - концепція досконалості, заснована на моделі досконалості Європейського фонду управління якістю (The European Foundation for Quality Management Excellence Model, EFQM Excellence Model) ${ }^{107}$, що була створена в 1992 р. для досягнення успіхів у бізнесі і стосувалася насамперед сфери управління. Модель досконалості EFQM ґрунтується на системі здійснення самооцінки - для встановлення сильних сторін і прогресу у досягненні досконалості та планування - за напрямами розвитку і поліпшення діяльності організації. Згідно з моделлю визначено ключові критерії, що розподіляються між п'ятьма можливостями (те, що робить організація), зокрема щодо лідерства, політики та стратегії, управління людьми, партнерства та ресурсів, управління процесами, і чотирма результатами (те, чого досягає організація), кожен з яких має підкритерії і маркери з відповідними зважувальними коефіцієнтами, що відображають важливість конкретного критерію ${ }^{108}$. Одержані дані корелюються з основними складниками досконалості ${ }^{109}$ : орієнтацією на результати, орієнтацією на клієнта, лідерством та сталістю цілей, управлінням процесами і фактами, розвитком та залученням людей, постійним навчанням, інноваціями і вдосконаленням, розвитком партнерства, громадською відповідальністю. Такий

\footnotetext{
100 Grimes D.R., Bauch C.T., loannidis J.P.A. Modelling science trustworthiness under publish or perish pressure. 2018. P. 13. R.Soc.Open Sci. 5: 171511. DOI : http://dx.doi.org/10.1098/rsos.171511.

101 Grimes D.R., Bauch C.T., loannidis J.P.A. Modelling science trustworthiness under publish or perish pressure. 2018. P. 1. R.Soc.Open Sci. 5: 171511. DOI : http://dx.doi.org/10.1098/rsos.171511.

102 Grime D.R., Bauch C.T., loannidis J.P.A. Modelling science trustworthiness under publish or perish pressure. 2018. R.Soc.Open Sci. 5: 171511. DOI : http://dx.doi.org/10.1098/rsos.171511.

${ }^{103}$ Research in International Management. Publish or Perish on Microsoft Windows. URL: https://harzing.com/resources/publish-orperish/windows.

104 Grimes D.R., Bauch C.T., loannidis J.P.A. Modelling science trustworthiness under publish or perish pressure. 2018. P. 13. R.Soc.Open Sci. 5: 171511. DOI : http://dx.doi.org/10.1098/rsos.171511.

105 Open Science in Ukraine. Програма Publish Or Perish. URL : https://openscience.in.ua/publish-or-perish.html.

106 Open Science in Ukraine. Програма Publish Or Perish. URL : $\underline{\text { https://openscience.in.ua/publish-or-perish.html. }}$

107 The European Foundation for Quality Management Excellence Model. URL : https://www.efam.org/index.php/efam-model/

108 Steed C. Excellence in Higher Education. Evaluating the Implementation of the Efam Excellence Model ${ }^{\circledR}$ in Higher Education in the UK. Beiträge zur Hochschulforschung. 2002. Heft 1, 24. Jahrgang. URL : https://www.bzh.bayern.de/uploads/media/1-2002-steed.pdf.

${ }^{109}$ Steed C. Excellence in Higher Education. Evaluating the Implementation of the Efqm Excellence Model ${ }^{\circledR}$ in Higher Education in the UK. Beiträge zur Hochschulforschung. 2002. Heft 1, 24. Jahrgang. P. 75. URL : https://www.bzh.bayern.de/uploads/media/1-2002-steed.pdf.
} 
розгорнутий аналіз є практичним інструментом до дії, дає змогу виявити недоліки, визначити цілі та пріоритетні цінності, віднайти потрібну мотивацію для вдосконалення процесів із залученням персоналу і досягнути необхідну досконалість.

Зазначену модель досконалості EFQM було успішно адаптовано та запроваджено в освітню практику систем вищої освіти країн Європи, США тощо 110; 111;112;113. Із поміж таких моделей варто виокремити поширену в США Рамку досконалості Baldrige (Baldrige Excellence Framework (Education) ${ }^{114}$, що охоплює сім важливих сфер діяльності 3ВО: лідерство; стратегію; студентство; вимірювання, аналіз та управління знаннями; академічний персонал; управління; результати організаційної діяльності. Наголошуючи на різних місіях, візіях ЗВО, ключовими цінностями за структурою досконалості Baldrige $\epsilon^{115}$ : перспективність, лідерство, досконалість, зорієнтована на студентство, оцінювання персоналу, організаційне навчання та гнучкість, успішність, управління інноваціями, фактичне управління, соціальний вимір, етика та прозорість, забезпечення цінності і результатів.

у Сполученому Королівстві основоположними для системи вищої освіти $\epsilon$ дві концепції досконалості у навчанні, що відображено у Концепції досконалості у вищій освіmi (The Concept of Excellence in Higher Education) ${ }^{116}$, та досконалості у наукових дослідженнях, що імплементується через Рамку досконалості досліджень (Research Excellence Framework, REF) ${ }^{117}$, а також Рамку розвитку дослідника (Researcher Development Framework) ${ }^{118}$ і Кодекс практики досліджень (Code of Practice for Research) ${ }^{119}$. Передусім варто розглянути дві перші з них.

Так, Керівництвом досконалості у вищій освіті встановлено відповідні критерії до освітньої діяльності інституцій, із-поміж яких міцне та прогресивне стратегічне управління на основі впевненого прагнення до досконалості в місії та цілях інституції, самопізнання сильних і слабких сторін та готовності до вдосконалення; і зокрема до дослідницької діяльності ${ }^{120}$ : сприяння дослідженням та академічному розвитку, що є одним із важливих показників кількості та якості дослідницької діяльності академічного персоналу; сприяння інтернаціоналізації через участь у міжнародному співробітництві у галузі досліджень та академічному розвитку; сприяння рівності та академічній свободі на основі забезпечення рівності можливостей академічного персоналу та його реалізації без будь-яких обмежень тощо.

Метою Рамки досконалості досліджень ${ }^{121} \in$ створення показників досконалості досліджень та їх використання для порівняння результатів діяльності ЗВО Великобританії із міжнародними стандартами. Вона використовується для 122;123: «вироблення надійних показників найкращих досліджень з усіх дисциплін, які можуть бути використані для оцінювання еталонної якості за міжнародними стандартами; першочерговості розподілу коштів для найкращих досліджень; значного зниження адміністративного навантаження на установи; створення стимулів поведінки заохочення рівності та різноманітності; забезпечення стабільної основи для постійної підтримки світової дослідницької бази».

Особливу увагу приділено впливу досліджень як засобу для оцінювання рентабельності інвестицій у

110 Calvo-Mora A., Leal A, Roldan J.L. Quality Assurance in Education: An International Perspective. 2006. Vol. 14. № 2. P. 99-122. URL: https://eric.ed.gov/?id=EJ801665.

${ }^{111}$ Steed C. Excellence in Higher Education. Evaluating the Implementation of the Efam Excellence Model ${ }^{\circledR}$ in Higher Education in the UK. Beiträge zur Hochschulforschung. 2002. Heft 1, 24. Jahrgang. URL : https://www.bzh.bayern.de/uploads/media/1-2002-steed.pdf.

${ }_{112} \mathrm{Abu}$ Saada I.J. Applying Leadership Criterion of EFQM Excellence. Model In Higher Education Institutions. URL: https://library.iugaza.edu.ps/thesis/109608.pdf.

113 Veenstra C.P. Work in progress Innovation using the baldrige process. 37th Annual Frontiers In Education Conference - Global Engineering: Knowledge Without Borders, Opportunities Without Passports, Milwaukee, WI, 2007, pp. T2G-24-T2G-25. DOI: http://dx.doi.org/10.1109/FIE.2007.4418052.

114 Baldrige Excellence Framework (Education). URL : https://www.nist.gov/baldrige/publications/baldrige-excellence-framework/education.

115 Baldrige Excellence Framework (Education). URL : https://www.nist.gov/baldrige/publications/baldrige-excellence-framework/education.

116 Brusoni M., Damian R., Sauri J.G.I, Jackson S., Kömürcügil H., Malmedy M., Matveeva O., Motova G., Pisarz S., Pol P., Rostlund A., Soboleva E., Tavares O., Zobel L. The Concept of Excellence in Higher Education. (2014). DOI : http://dx.doi.org/10.13140/PГ.2.1.2146.7683.

117 Research Excellence Framework. URL : https://www.ucl.ac.uk/research/ref.

118 Researcher Development Framework. 2009. URL: https://www.vitae.ac.uk/vitae-publications/rdf-related/researcher-developmentframework-rdf-vitae.pdf/view.

${ }^{119}$ Code of Practice for Research. Promoting good practice and preventing misconduct. September 2009. URL: https://ukrio.org/wpcontent/uploads/UKRIO-Code-of-Practice-for-Research.pdf.

120 Brusoni M., Damian R., Sauri J.G.I, Jackson S., Kömürcügil H., Malmedy M., Matveeva O., Motova G., Pisarz S., Pol P., Rostlund A., Soboleva E., Tavares O., Zobel L. The Concept of Excellence in Higher Education. (2014). P. 30-32. DOI : http://dx.doi.org/10.13140/PГ.2.1.2146.7683.

${ }^{121}$ Research Excellence Framework. URL : https://www.ucl.ac.uk/research/ref.

122 Research Excellence Framework 2014: The results. URL : https://www.ref.ac.uk/2014/pubs/201401/

123 Драч І.І. Філософський аналіз практики дослідницького врядування в університетах Великої Британії. Університети і лідерство. 2018. № 2 (6). C. 45-57. C. 48. URL : https://doi.org/10.31874/2520-6702-2018-6-2-45-57. 
наукову діяльність, що підтверджується змінами або перевагами проведених досліджень. Із огляду на це, досконалість оцінюється в площині кількісних показників наукової діяльності, включаючи і бібліометричні показники, фінансове забезпечення, підготовку аспірантів. Важливим складником оцінювання є експертна оцінка про дослідницьке середовище, якість результатів досліджень, що ґрунтується на критеріях, і рівнях, згідно з якими якість може бути ${ }^{124 ; 125:}$

- провідною у світі за оригінальністю, значущістю, новизною;

- чудовою на міжнародному рівні за оригінальністю, значущістю, але не відповідає найвищим стандартам досконалості;

- визнаною на міжнародному рівні за оригінальністю, значущістю;

- визнаною на національному рівні за оригінальністю, значущістю;

- нижче стандарту загальновизнаної роботи (або роботи, яка не відповідає опублікованому визначенню дослідження для цілей цієї оцінки).

Саме ураховуючи такі критерії досконалості здійснюється фінансове забезпечення, внаслідок чого інвестиції спрямовуються на дослідження, які засвідчують результати світового класу. Крім того, проведене оцінювання відповідно до Рамки досконалості досліджень та одержані результати підтверджують не лише якість досліджень, а й надають університетам всебічне уявлення про їх сильні і слабкі сторони та допомагають вибудувати стратегічне планування і прийняття необхідних рішень 3 метою покращання діяльності загалом ${ }^{126}$.

Узагальнюючи в цілому проблему досконалості в рамках університету (особливо світового класу) для оцінювання і розвитку дослідницької діяльності вченого, то це означає ${ }^{127}$ : досконалість у дослідженнях; висококваліфікований академічний персонал (професори); сприятливі умови праці і безпека роботи; хороша зарплата та пільги; адекватне фінансування, включаючи передбачуваність із року в рік; академічна свобода та атмосфера інтелектуального хвилювання; факультетське самоврядування. Саме цінність концепції досконалості полягає в тому, що вона застосовується в контексті визначених ключових критеріїв і цінностей, їі можна оцінити на основі узгоджених стандартів, що має вагоме значення на індивідуальному рівні та збагачує і стимулює реалізацію людського потенціалу.

Нині триває підготовка нової Рамки досконалості досліджень, яку передбачено оприлюднити у 2021 році.

Рамка розвитку дослідника, що ґрунтується на ключових засадах концепції досконалості, зорієнтована для вчених, які «планують та оцінюють свій професійний розвиток; керівників та супервізорів для підтримки розвитку дослідників; фахівців з кадрових ресурсів» ${ }^{128}$, 3 метою з'ясування власних сильних / слабких сторін і відповідно до цього визначення ціннісних орієнтирів для особистого та кар'єрного просування», і детально представлена в роботі І.І. Драч ${ }^{129}$.

Отже оцінювання дослідника розглядається в площині двох концептуальних теорій - бібліометрії і наукометрії, що ґрунтується на метричних показниках опублікованих праць дослідника передусім у престижних журналах, кількості цитувань тощо з урахуванням імплементації моделі «надійності науки», та на засадах теорії досконалості, ключовим складником якої є експертна оцінка, що враховує насамперед якість проведеного дослідження відповідно до встановлених стандартів, дає змогу визначити сильні і слабкі сторони та відповідно до цього - професійний розвиток.

У нашому розумінні оцінювання і розвиток наукової діяльності науково-педагогічного працівника - це встановлення відповідності наукової діяльності вченого університету вимогам стандарту до посади на основі експертного висновку, що формується за результатами комплексної експертної оцінки з урахуванням метричних показників, і дає змогу виявити переваги і недоліки та вибудувати дослідницьку перспективу і професійне зростання вченого.

\footnotetext{
124 Research Excellence Framework 2014: The results. URL : https://www.ref.ac.uk/2014/pubs/201401/

125 Brusoni M., Damian R., Sauri J.G.l, Jackson S., Kömürcügil H., Malmedy M., Matveeva O., Motova G., Pisarz S., Pol P., Rostlund A., Soboleva E., Tavares O., Zobel L. The Concept of Excellence in Higher Education. (2014). P. $12 . \quad$ DOI : https://doi.org/10.13140/РГ.2.1.2146.7683.

${ }^{126}$ Stern N. «Building on success and learning from experience: an independent review of the Research Excellence Framework». 2016. P. 9. URL : https://assets.publishing.service.gov.uk/government/uploads/system/uploads/attachment_data/file/541338/ind-16-9-ref-stern-review.pdf.

127 Altbach P. The Costs and Benefits of World-Class Universities. International Higher Education. 2003. № 33. DOI : https://doi.org/10.6017/ihe.2003.33.7381.

128 Драч І.І. Філософський аналіз практики дослідницького врядування в університетах Великої Британії. Університети і лідерство. 2018. № 2 (6). C. 45-57. C. 51. DOI : https://doi.org/10.31874/2520-6702-2018-6-2-45-57.

129 Драч І.І. Філософський аналіз практики дослідницького врядування в університетах Великої Британії. Університети і лідерство. 2018. № 2 (6). C. 45-57. C. 51. DOI : https://doi.org/10.31874/2520-6702-2018-6-2-45-57.
} 


\section{Принципи оцінювання та розвитку дослідницької діяльності НПП}

У державах - членах $\in C$ академічна кар'єра в університетах більшою мірою пов'язана з науковими дослідженнями, ніж з викладанням, зокрема під час добору на роботу, співбесід, оцінювання, подальшого професійного розвитку та встановлення винагороди. Домінуючим чинником для оцінювання, особливо у дослідницьких університетах, $є$ наукові результати академічного персоналу, зокрема наявність наукового ступеня, досвід проведення наукових досліджень, а також задокументовані дослідницькі компетентності (наукові публікації, h-індекс, фінансування досліджень тощо) ${ }^{130} .3$ огляду на зазначене, виникає професійний інтерес щодо базових засад, які слугують пріоритетними орієнтирами в оцінюванні наукової діяльності викладачів університетів.

\section{Пріоритетні принципи оцінювання та розвитку дослідницької діяльності вчених в країнах ЄС}

Основоположні принципи політики ЄС щодо оцінювання діяльності дослідників та забезпечення їх професійного розвитку визначені у Європейській хартії дослідників і Кодексі працевлаштування наукових працівників (The European Charter for Researchers \& the Code of Conduct for their Recruitment, 2005) ${ }^{131}$ та Кодексі практики досліджень (Code of Practice for Research, 2009) ${ }^{132}$.

Так, у рекомендаціях Європейської хартії дослідників запропоновано пріоритетні принципи, якими мають керуватися держави-члени ЄС на національному, регіональному, галузевому та інституційному рівнях для ухвалення своїх стратегій та інших установчих документів. Крізь призму загальних принципів визначено повноваження (обов'язки та права) вчених і роботодавців з метою створення ефективної системи їх взаємодії, зокрема сприяння успішним результатам у процесі «генерування, передачі, обміну та розповсюдження знань, а також оцінювання та розвитку кар'єри дослідників» (The European Charter for Researchers \& the Code of Conduct for their Recruitment, 2005, p. 7-10) ${ }^{133}$. Ключовими принципами для діяльності наукових працівників встановлено ${ }^{134}$ : свободу наукових досліджень, етичні принципи, професійну відповідальність, професійний підхід, контрактні та правові обов'язки, відповідальність, дотримання безпеки у наукових дослідженнях, поширення і використання результатів, участь у житті суспільства, стосунки 3 науковим керівником, керівництво та управління, постійний професійний розвиток.

До загальних принципів для роботодавців, які представлено у Кодексі працевлаштування наукових працівників, віднесено ${ }^{135}$ : визнання професії, недискримінацію, дослідницьке середовище, умови праці, стабільність і неперервність працевлаштування, фінансування та заробітну плату, гендерний баланс, розвиток кар'єри, цінність мобільності, доступ фахової підготовки та можливості постійного професійного розвитку, доступ до консультування з питань кар'єри, права інтелектуальної власності, співавторство, наукове керівництво, викладацьку діяльність, системи оцінки вчених, скарги/звернення, участь в органах ухвалення рішень, працевлаштування (рекрутація). У контексті нашого дослідження важливими $є$ наративи про необхідність запровадження «єдиної системи оцінювання / атестації професійних досягнень» ${ }^{136}$ за участі незалежної комісії, а також забезпечення з боку роботодавців можливості для кар'єрного зростання «шляхом забезпечення доступу до засобів, що дають змогу постійно розвивати нові компетенції та набувати нових кваліфікацій» 137.

\footnotetext{
130 Kobayashi S., Dolin J., Søborg A., Turner J. (2017). Building Academic Staff Teaching Competencies: How Pedagogic Continuous Professional Development for Academic Staff Can Be Organised and Developed in Research-Intensive Universities. DOI : https://doi.org/10.1007/978-3-31956499-9 5.

${ }_{131}$ The European Charter for Researchers \& the Code of Conduct for their Recruitment. Європейська хартія дослідників та Кодекс працевлаштування наукових працівників. URL : http://h2020.com.ua/wp-content/uploads/2015/11/Book.pdf.

${ }_{132}$ Code of Practice for Research. Promoting good practice and preventing misconduct. September 2009. C. 6. URL : https://ukrio.org/wpcontent/uploads/UKRIO-Code-of-Practice-for-Research.pdf

133 The European Charter for Researchers \& the Code of Conduct for their Recruitment. Європейська хартія дослідників та Кодекс працевлаштування наукових працівників. С. 7-10. URL : http://h2020.com.ua/wp-content/uploads/2015/11/Book.pdf.

134 The European Charter for Researchers \& the Code of Conduct for their Recruitment. Європейська хартія дослідників та Кодекс працевлаштування наукових працівників. С. 7-10. URL : http://h2020.com.ua/wp-content/uploads/2015/11/Book.pdf.

135 The European Charter for Researchers \& the Code of Conduct for their Recruitment. Європейська хартія дослідників та Кодекс працевлаштування наукових працівників. С. 11-17. URL : http://h2020.com.ua/wp-content/uploads/2015/11/Book.pdf.

136 The European Charter for Researchers \& the Code of Conduct for their Recruitment. Європейська хартія дослідників та Кодекс працевлаштування наукових працівників. С. 16. URL : http://h2020.com.ua/wp-content/uploads/2015/11/Book.pdf.

137 The European Charter for Researchers \& the Code of Conduct for their Recruitment. Європейська хартія дослідників та Кодекс працевлаштування наукових працівників. С. 13. URL : http://h2020.com.ua/wp-content/uploads/2015/11/Book.pdf
} 
Наведені вище документи свідчать про необхідність урахування різноманітних повноважень викладачів, які не тільки проводять наукові дослідження, але також беруть участь у науковому нагляді, наставництві, чи здійснюють управлінські або адміністративні функції у дослідницькій сфері.

Про відповідність керівним принципам і стандартам, що визначають обов'язки і цінності вчених щодо проведення наукових досліджень, наголошується у Кодексі практики досліджень (Code of Practice for Research, 2009) ${ }^{138}$. Запропоновані ціннісні принципи $€$ базовими в оцінюванні дослідницької діяльності академічного персоналу, з поміж яких ${ }^{139}$ :

- досконалість (excellence), що проявляється через майстерність проведення наукових проєктів;

- чесність (honesty), що засвідчує правдивість власних результатів досліджень вчених і їх неупереджене ставлення до інших досліджень;

- доброчесність (integrity), якої має дотримуватися академічний персонал, запобігаючи неетичним діям;

- співробітництво (co-operation), що ґрунтується на відкритому доступі та обміні щодо проведення досліджень та їх результатів;

- відповідальність (accountability), яка передбачає прозорість, дотримання укладених угод і підзвітність, зокрема у рамках 3 ВО і перед громадою;

- навчання та навички (training and skills), які, з одного боку, мають забезпечувати університети і надавати усіляку підтримку розвитку академічному персоналу та здійсненні ними досліджень, з іншого вчені мають володіти необхідними навичками для реалізації відповідних наукових проєктів;

- безпека (safety), яка дає змогу для нешкідливої організації дослідницької діяльності, забезпечення гідності і прав учасників досліджень та завчасного запобігання ризикам.

\section{Ключові принципи оцінювання дослідників відповідно до Сан-Франциської декларації про оцінку наукових досліджень та Лейденського маніфесту}

Наступним кроком щодо оцінювання дослідницької діяльності академічного персоналу $\epsilon$ СанФранциська декларація про оцінку наукових досліджень (San Francisco Declaration on Research Assessment, DORA, 2012) ${ }^{140}$, в якій подано рекомендації щодо покращання якості оцінювання результатів наукових досліджень для установ, що фінансують дослідження; установ, де виконуються дослідження; організацій, що здійснюють наукометричний аналіз; видавців і дослідників. Головною настановою, зокрема для вчених $\epsilon{ }^{141}$ :

- оцінювання дослідницької діяльності при прийомі на роботу, перебуванні на посаді і просуванні по службі на основі наукового змісту досліджень, а не за метричними даними;

- надання переваги оригінальним працям на противагу оглядовим;

- використання різноманітних метрик для наукових праць, як доказ значущості;

- застосування кращих практик, які враховують вагомість і вплив результатів досліджень.

Десять принципів Лейденського маніфесту для наукометрії (The Leiden Manifesto for research metrics, 2014) ${ }^{142}$ запропоновано як базові принципи оцінювання дослідницької діяльності, що мають вагоме значення у розвитку науки та її вплив на суспільство, а також підтверджують об'єктивний висновок результатів діяльності вченого ${ }^{143 ;} 144$ :

«- доповнення якісної, експертної оцінки кількісними даними;

- співставлення результативності згідно з дослідницькими місіями установи, групи чи дослідника;

- захист досконалості досліджень, важливих для відповідного регіону;

- збереження даних та аналітичних процесів відкритими, прозорими та простими;

- надання дозволу вченим, яких оцінюють, перевіряти дані та аналіз результатів;

\footnotetext{
${ }^{138}$ Code Of Practice For Research. Promoting good practice and preventing misconduct. September 2009. URL: https://ukrio.org/wpcontent/uploads/UKRIO-Code-of-Practice-for-Research.pdf.

${ }_{139}$ Code Of Practice For Research. Promoting good practice and preventing misconduct. September 2009. P. 7. URL : https://ukrio.org/wpcontent/uploads/UKRIO-Code-of-Practice-for-Research.pdf.

140 San Francisco Declaration on Research Assessment. URL : https://sfdora.org/read/

141 San Francisco Declaration on Research Assessment. URL: https://sfdora.org/read/

142 Hicks D., Wouters P., Waltman L., Rijcke S., Rafols I. Bibliometrics: The Leiden Manifesto for research metrics. April 2015. Nature 520 (520):429-431. URL : https://www.nature.com/news/bibliometrics-the-leiden-manifesto-for-research-metrics-1.17351.

143 Hicks D., Wouters P., Waltman L., Rijcke S., Rafols I. Bibliometrics: The Leiden Manifesto for research metrics. April 2015. Nature 520 (520):429-431. URL : https://www.nature.com/news/bibliometrics-the-leiden-manifesto-for-research-metrics-1.17351.

144 Бібліометрія: Лейденський маніфест для наукометрії. Філософська думка. 2017. № 6. С. 93-98.
} 
- врахування галузевої специфіки відповідно до практики публікацій та цитування;

- врахування для окремих дослідників якісної оцінки їх портфоліо;

- запобігання надмірної конкретності кількісних показників;

- визнання системного впливу оцінок та індикаторів;

- систематичний перегляд та оновлення системи індикаторів».

Отже провідною ідеєю в оцінюванні дослідників $€$ вплив результатів досліджень на суспільство, значущість наукового змісту та експертна оцінка, досконалість досліджень відповідно до місії, сфери науки, регіону, врахування наукометричних індикаторів.

\section{Гонконгські принципи оцінювання дослідників в умовах переходу до відкритої науки}

Нового змісту оцінювання і професійний розвиток дослідників набуває в умовах переходу наукової спільноти до відкритої науки і відкритого доступу до результатів дослідження. Розгортання наведених вище базових принципів у такому контексті простежується в Гонконгських принциnax (Hong Kong Principles, HKPs, 2019) ${ }^{145}$, дотримання яких, на думку розробників, забезпечить об'єктивне оцінювання, чітке визнання і винагороду дослідників за їх діяльність щодо надійності і досконалості досліджень. Запропоновані п'ять принципів ґрунтуються на широкомасштабній доказовій практичній базі та зорієнтовані на відповідальну дослідницьку діяльність і запобігання нечесних дослідницьких практик ${ }^{146}$. До таких принципів віднесено ${ }^{147}$ :

- оцінювання вчених щодо відповідальності проведення дослідження, включаючи розроблення ідеї дослідження, оформлення дослідження, методологію, виконання та ефективне розповсюдження, оскільки наукометричні індикатори не повною мірою відображають значення публікації і внесок вченого у дослідження та відповідний вплив на суспільство;

- оцінювання і значущість повної звітності, з огляду на всі проведені вченим заходи та неопубліковані результати, що засвідчує точність і прозорість його дослідницької діяльності і має важливе значення для відтворюваності і можливості повторного використання даних в умовах відкритої науки;

- винагорода за практику відкритої науки (відкритого дослідження на основі відкритого доступу, відкритих методів, відкритих даних тощо), що забезпечує рівність дослідницького процесу і підвищує прозорість, яка є основним принципом цілісності дослідження, а також дає змогу ідентифікувати вченого;

- визнання широкого діапазону дослідницької діяльності вченого, реплікації, інновації, переклад, синтез та мета-дослідження, обгрунтування проектних пропозицій тощо, оскільки це зумовлює відповідні часові рамки для оцінювання різних типів досліджень;

- визнання інших внесків у відповідальну наукову діяльність вченого, зокрема рецензування та наставництво через лідерство, зважаючи на те, що експертна оцінка залишається наріжним каменем оцінки якості грантів, публікацій, конференцій, журналів, дисертацій тощо, із залученням громадськості як шляхів розповсюдження наукових знань у суспільстві від дослідників університету.

У цілому впровадження принципів HKPs з метою зміцнення цілісності досліджень сприятиме оцінюванню вчених та їх кар'єрному просуванню. Крім того, відкрита поведінка вченого, що забезпечує доброчесність досліджень, повинна бути визнана та відзначена. Університети зобов'язані втілювати і дотримуватися наведених принципів, а також стимулювати, винагороджувати та оцінювати дослідників за їх наукову діяльність, що сприяє доброчесності досліджень ${ }^{148}$.

\section{Найважливіші принципи оцінювання дослідників Асоціації Європейських Університетів}

У сучасних умовах оцінювання вчених та вибудовування на цій основі розвитку дослідницької діяльності є одним із важливих складників політики Асоціації Європейських Університетів (European University Association, EUA) ${ }^{149}$, що підтверджується низкою заяв, звітів та ухвалених ініціатив. Про необхідність розроблення та впровадження прозорих і відповідальних підходів до наукового оцінювання досліджень

\footnotetext{
145 Moher D., Bouter L., Kleinert S., Glasziou P., Sham M.H., Barbour V., et al. (2020) The Hong Kong Principles for assessing researchers: Fostering research integrity. PLoS Biol 18 (7): e3000737. DOI : https://doi.org/10.1371/journal.pbio.3000737.

146 The National Academies Press. Fostering Integrity in Research. URL : https://sites. nationalacademies.org/PGA/PGA 178432.

147 Moher D., Bouter L., Kleinert S., Glasziou P., Sham M.H., Barbour V., et al. (2020) The Hong Kong Principles for assessing researchers: Fostering research integrity. PLoS Biol 18 (7): e3000737. DOI : https://doi.org/10.1371/journal.pbio.3000737.

148 Moher D., Bouter L., Kleinert S., Glasziou P., Sham M.H., Barbour V., et al. (2020). P. 9. The Hong Kong Principles for assessing researchers: Fostering research integrity. PLoS Biol 18 (7): e3000737. DOI : https://doi.org/10.1371/journal.pbio.3000737.

149 European University Association. URL : https://eua.eu/
} 
наукових організацій і університетів та дослідників наголошується у спільній заяві EUA ma Science Europe (2019) ${ }^{150}$. Згідно з заявою необхідним $є$ забезпечення ${ }^{151}$ :

- реалізації відповідних змін для успішного балансу між якісними і кількісними підходами до оцінювання досліджень, а також розроблення нових критеріїв та методів для об'єктивного і прозорого оцінювання дослідників, що сприятиме здійсненню якісного конкурсного відбору досліджень і вчених;

- визнання різноманітності результатів досліджень та їх прийнятих спільних заяв і ухвалених ініціатив, значущості з урахуванням кожної галузі досліджень на противагу надмірній залежності від метричного оцінювання досліджень і вчених на основі публікацій в журналах, віднесених до наукометричних баз даних;

- розроблення широкого діапазону критеріїв для винагород дослідників і стимулювання якості наукових робіт, як основного принципу наукових досліджень, та визначення процесів і методів оцінювання, що достовірно відображають багатогранні виміри якості досліджень та враховують наукові здобутки вченого.

\section{Принципи оцінювання та розвитку наукової діяльності НПП}

У національному законодавчому просторі найбільш розгорнуто представлено принцип академічної доброчесності, який відображений у законах України «Про освіту» ${ }^{152}$, «Про вищу освіту» ${ }^{153}$, а також у «Методичних рекомендаціях для закладів вищої освіти з підтримки принципів академічної доброчесності» ${ }^{154}$. Зрозуміло, що академічна доброчесність і відповідальність, за результатами загальнонаціонального опитування академічного персоналу 373 ВО України ${ }^{155} \in$ одними 3 пріоритетних ціннісних принципів. Натомість академічна свобода, як один із чинників, що пливає на якість вищої освіти, має низьку оцінку, що зумовлено асоціативним рядом викладачів на вимушене виконання відповідних інституційних директив, і не пов'язане з мотивацією на саморозвиток і самовдосконалення ${ }^{156}$. Таке розуміння, на нашу думку, свідчить про недостатню обізнаність НПП із європейськими цінностями і принципами, що треба мати на увазі під час розроблення документів у сфері освіти національного та інституційного рівнів.

Важливим у визначенні принципів оцінювання та розвитку наукової діяльності НПП $є$ врахування наукового пошуку українських вчених, які досліджували означену проблему в контексті створення професійного профілю, кар'єрного зростання, розвитку дослідницької, ціннісної, комунікативної, іншомовної компетентності, професійного розвитку, дослідницького врядування в університетах тощо.

Зокрема, Ю.А. Скиба, висвітлюючи розроблення професійного профілю НПП, обґрунтував такі принципи 157: «забезпечення визнання якісного викладання; заохочення НПП прагнути до вищого рівня ефективності; орієнтація на результати навчання, щоб забезпечити міцний зв'язок між стандартами вищої освіти і професійними стандартами; орієнтування на компетентності; акумулятивність характеру дескрипторів; самооцінювання та зовнішнє оцінювання НПП; рефлексія професійних практик НПП; відкритість профілю НПП».

Основними принципами кар'єрного зростання викладачів, на думку Г.П. Чорнойван, $\epsilon^{158}$ : «принципи

150 The European University Association and Science Europe Join Efforts to Improve Scholarly Research Assessment Methodologies. URL : http://www.scienceeurope.org/media/xybdxw0e/joint-statement-eua-se-on-research-assessment-1.pdf.

151 The European University Association and Science Europe Join Efforts to Improve Scholarly Research Assessment Methodologies. URL : http://www.scienceeurope.org/media/xybdxw0e/joint-statement-eua-se-on-research-assessment-1.pdf.

152 Про освіту : Закон України від 05.09.2017 № 2145-VIII. URL : https://zakon.rada.gov.ua/laws/show/2145-19\#Text.

153 Про вищу освіту : Закон України від 01.07.2014 № 1556-VII. URL : https://zakon.rada.gov.ua/laws/show/1556-18\#Text.

154 Методичні рекомендації для закладів вищої освіти з підтримки принципів академічної доброчесності (2018). URL: https://mon.gov.ua/storage/app/media/vishcha-osvita/2018/10/25/recomendatsii.pdf.

155 Результати загальнонаціонального опитування «Перспективи та потреби розвитку університетів України у процесі реформування вищої освіти у контексті європейської інтеграції» / авт. кол. Київ: Інститут вищої освіти НАПН України, 2019. 77 с. Університети і лідерство. 2019. № 2 (8). С. 144-220. C.193. DOI : https://doi.org/10.31874/2520-6702-2019-8-2-144-220.

156 Луговий В., Оржель. О., Таланова Ж. Забезпечення якості вищої освіти в університетах України. Оцінювання якості вищої освіти в умовах євроінтеграції: методичні рекомендації. / авт. кол. Київ : Ін-т вищої освіти НАПН України, 2019. 125 с. С. 21. DOI: https://doi.org/10.31874/978-617-7486-33-5-2019.

157 Скиба Ю.А. Професійний профіль і кваліфікаційні рівні науково-педагогічних працівників університетів в умовах інтеграції вищої освіти і науки. Теоретичні основи і технологія професійного розвитку науково-педагогічних працівників університетів в умовах інтеграції вищої освіти і науки : монографія / авт. кол. К. : Інститут вищої освіти HAПН України, 2019. 236 с. С. 34. URL: https://ihed.org.ua/wp-content/uploads/2020/04/Tehnologiva prof rozvitku pracivn VNZ Monogr IVO-2019-236p avtors-kolektiv.pdf.

158 Чорнойван Г. Теоретичні основи і технології кар'єрного розвитку науково-педагогічних працівників у контексті інтеграції викладацької і дослідницької діяльності. Теоретичні основи і технологія професійного розвитку науково-педагогічних працівників університетів в 
безперервності (мотивація до навчання впродовж життя), загальнометодичні, андрагогічні, осмисленості, пропорційності, професійної мобільності тощо».

Рівневий підхід у представленні принципів організації й управління процесом професійного розвитку НПП застосував О.В. Жабенко, а саме ${ }^{159}$ : на національному, інституційному та індивідуальному рівнях, що дало змогу вибудувати технологію професійного розвитку викладача.

Важливими в контексті оцінювання наукової діяльності $є$ принципи розвитку дослідницької компетентності НПП, розроблені О.Г. Ярошенко, 3-поміж яких визначено принципи ${ }^{160:}$ функціональної єдності, наступності, неперервності, гнучкості, варіативності, добровільності, відкритості, транснаціональності, академічної доброчесності.

Базовими для будь-яких принципів діяльності НПП є ціннісні принципи, до яких віднесено ${ }^{161}$ : професіоналізм; моральність та етичність; відповідальність; неупередженість; довіру; успішність; пріоритетність; ідентифікацію; лідерство.

На окрему увагу заслуговують принципи дослідницького врядування в університетах, розроблені I.І. Драч, на основі досвіду університетів Великої Британії, а саме принципи ${ }^{162}$ : доброчесності, відповідальності, моніторингу, відкритості, співробітництва, неперервного розвитку дослідників.

Отже, ключовими принципами оцінювання та розвитку науково-педагогічних працівників у частині їх наукової діяльності, на нашу думку, є:

- академічна доброчесність, на якій ґрунтується достовірність здобутих наукових результатів, неупереджене ставлення до інших досліджень і вчених, забезпечення гідності і прав учасників досліджень та завчасного запобігання ризиків недоброчесності;

- досконалість, що реалізується через довершеність і професіоналізм у провадженні наукової діяльності, зокрема реалізації дослідницьких проєктів, наукового нагляду, співробітництва та адміністративних повноважень тощо;

- академічна свобода, що провадиться, з одного боку, у площині підтримки прав вченого, без будьякої його дискримінації, з іншого - пов'язана з відповідальністю, високими етичними стандартами та чесністю;

- відповідальність на основі сумлінності виконання наукових досліджень, здійснення наукового керівництва дослідницькими проєктами і успішного наставництва для молодих вчених, у дотриманні відповідних зобов'язань та звітності перед академічною спільнотою з урахуванням впливу на суспільство;

- безперервність, яка передбачає систематичне виконання вченим наукових досліджень і засвідчує його продуктивність, результативність і вплив, як чинники у кар'єрному зростанні;

- відкритість, що засвідчує прозорість і рівність дослідницького процесу, відкритий обмін щодо проведення досліджень і їх результатів та $€$ важливим для відтворюваності і можливості повторного використання даних в умовах відкритої науки;

- лідерство як розподілену відповідальність дослідницької команди і встановлення горизонтальних комунікацій серед академічного персоналу на засадах толерантності, демократичності та партнерства;

- моніторинг, що здійснюється на основі самооцінювання наукових здобутків, кореляції відповідно до поставлених цілей та визначення професійного зростання.

умовах інтеграції вищої освіти і науки : монографія / авт. кол. К. : Інститут вищої освіти HАПН України, 2019. 236 с. С. 34. C. 91. URL : https://ihed.org.ua/wp-content/uploads/2020/04/Tehnologiya_prof rozvitku_pracivn_VNZ_Monogr IVO-2019-236p_avtors-kolektiv.pdf.

159 Жабенко О.В. Професійний розвиток науково-педагогічних працівників університетів в умовах інтеграції вищої освіти і науки: моделі і технологія. Теоретичні основи і технологія професійного розвитку науково-педагогічних працівників університетів в умовах інтеграції вищої освіти і науки : монографія / авт. кол. К. : Інститут вищої освіти HAПН України, 2019. 236 с. С. 71-74. URL : https://ihed.org.ua/wp-content/uploads/2020/04/Tehnologiya_prof_rozvitku_pracivn_VNZ_Monogr_IVO-2019-236p_avtors-kolektiv.pdf.

160 Ярошенко О.Г. Теоретичні основи розвитку дослідницької компетентності науково-педагогічних працівників в умовах інтеграції вищої освіти і науки. Міжнародний науковий журнал "Університети і лідерство». 2018. № 1 (5). С. 26-36.

161 Регейло І.Ю. Розвиток ціннісної компетентності науково-педагогічних працівників університетів в умовах інтеграції вищої освіти і науки. Теоретичні основи і технологія професійного розвитку науково-педагогічних працівників університетів в умовах інтеграції вищої освіти і науки : монографія / авт. кол.: О.Г. Ярошенко, О.В. Жабенко, Ю.А. Скиба, Н.О. Дівінська, І.Ю. Регейло, Г.П. Чорнойван ; за ред. О.Г. Ярошенко. К. : Інститут вищої освіти НАПН України, 2019. 236 с. С. 207. URL: https://ihed.org.ua/wpcontent/uploads/2020/04/Tehnologiva_prof rozvitku_pracivn VNZ Monogr IVO-2019-236p_avtors-kolektiv.pdf.

162 Драч І.І. Управління дослідницькою діяльністю в системі університетського врядування: теоретичні основи. Аналіз провідного вітчизняного та зарубіжного досвіду розвитку щодо механізмів реалізації ефективного врядування в університетах : препринт (аналітичні матеріали) (частина I) / авт. кол.: І. Драч, С. Калашнікова, О. Паламарчук, В. Рябченко, Л. Червона ; за заг. ред. С. Калашнікової. К. : Інститут вищої освіти НАПН України, 2018. С. 67. URL: https://ihed.org.ua/wpcontent/uploads/2019/09/Analiz dosvidu vriaduvania v univer ch1 analit IVO-2018-147p avtors-kolektiv.pdf. 


\section{Структура оцінювання і розвитку дослідницької діяльності НПП та ключові показники}

\section{Структура оцінювання дослідників в Європейському дослідницькому просторі}

Згідно з Європейською хартією дослідників для розвитку і професійного зростання вченого необхідно враховувати такі структурні компоненти в системі оцінювання ${ }^{163}$ : «потенціал наукової творчості та результати дослідницької діяльності, наприклад, публікації і патенти, управління дослідженнями, викладацьку діяльність, наукове керівництво, наставництво, національну та міжнародну співпрацю, виконання адміністративних обов'язків, науково-популярну діяльність та мобільність». Однак питання про визначення основних видів діяльності та її індикаторів $є$ неоднозначним і викликає активні дискусії у Європейському дослідницькому npocmopi (European Research Area, ERA) ${ }^{164}$. Для 3'ясування структурних складників оцінювання діяльності вчених та їх досліджень в європейських університетах представлено звіт про результати опитування EUA Open Science and Access ${ }^{165}$, у якому взяли участь 260 університетів із 32 європейських країн. Виявлено, що у понад $75 \%$ університетів в оцінюванні дослідницької діяльності академічного персоналу найважливіші $€$ показники щодо наукових публікацій і на їх основі фінансування наукових досліджень ${ }^{166}$. у близько $50 \%-75 \%$ європейських 3 ВО враховують також вплив досліджень та передачу здобутих результатів / наукових знань (кількість патентів, ліцензій); наукову співпрацю у науковому співтоваристві (співавторство публікацій, міждисциплінарні дослідження, міжінституційна співпраця); керівництво науковим проєктом; викладацьку діяльність; наукову співпрацю поза академічними інституціями, зокрема з представниками приватного сектору, уряду, а також участь у конференціях ${ }^{167}$. Натомість найнижчою за значущістю $€$ діяльність у межах відкритої науки та доступу, і лише у понад третини університетів такий напрям $€$ дуже важливим під час оцінювання дослідників, незважаючи на відсутність стимулів і винагород для професійного розвитку дослідників і їх кар'єрного зростання 168.

Все ж до найпоширеніших способів оцінювання діяльності дослідників належать, по-перше, показники на основі кількості публікацій у журналах, що індексуються у міжнародних наукометричних базах даних Scopus i Web of Science, та цитування (h-індекс), по-друге, експертна діяльність або рецензування, потретє, показники впливу на дослідження та передачі знань, зокрема, права інтелектуальної власності (патенти та ліцензії) ${ }^{169}$. Для оцінювання вчених також можуть враховуватися показники, що вимірюють академічну співпрацю на основі співавторства, індикатори Open Science and Access, що підтверджують результати досліджень та їх дані, Altmetrics для соціального охоплення публікацій тощо ${ }^{170}$. У такому оцінюванні поєднується якісний аналіз та кількісні критерії, що забезпечує об'єктивну оцінку для побудови успішного професійного шляху вченого.

\section{Використання альтметрик в оцінюванні дослідницької діяльності вченого}

Упродовж останніх років у зарубіжному освітньому і науковому просторі актуалізується питання про використання альтметрик в оцінюванні діяльності дослідника. Особливо така проблема набула актуальності в умовах світової пандемії COVID-19, оскільки через посилення цифровізації освітнього і наукового процесів, велику роботу дослідники проводять у соціальних мережах, які швидкими темпами набувають широкої популярності, що забезпечує досліднику відповідну «видимість» не тільки для наукової чи освітньої спільноти, але і для суспільства загалом. Оцінювання на основі альтернативних метрик розширює сферу застосування звичайних показників успішності дослідника і забезпечує всебічне та більш об'єктивне

\footnotetext{
163 The European Charter for Researchers \& the Code of Conduct for their Recruitment. Європейська хартія дослідників та Кодекс працевлаштування наукових працівників. С. 15. URL : http://h2020.com.ua/wp-content/uploads/2015/11/Book.pdf.

${ }^{164}$ European research area (ERA). URL : https://ec.europa.eu/info/research-and-innovation/strategy/era_en.

165 Saenen B., Morais R., Gaillard V., Borrell-Damián L. Research Assessment in the Transition to Open Science. (2019). URL: https://eua.eu/resources/publications/888:research-assessment-in-the-transition-to-open-science.html.

166 Saenen B., Morais R., Gaillard V., Borrell-Damián L. Research Assessment in the Transition to Open Science. (2019). P. 20. URL: https://eua.eu/resources/publications/888:research-assessment-in-the-transition-to-open-science.html.

167 Saenen B., Morais R., Gaillard V., Borrell-Damián L. Research Assessment in the Transition to Open Science. (2019). P. 21-22. URL: https://eua.eu/resources/publications/888:research-assessment-in-the-transition-to-open-science.html.

168 Saenen B., Morais R., Gaillard V., Borrell-Damián L. Research Assessment in the Transition to Open Science. (2019). P. 22. URL: https://eua.eu/resources/publications/888:research-assessment-in-the-transition-to-open-science.html.

169 Saenen B., Morais R., Gaillard V., Borrell-Damián L. Research Assessment in the Transition to Open Science. (2019). P. 22. URL: https://eua.eu/resources/publications/888:research-assessment-in-the-transition-to-open-science.html.

170 Saenen B., Morais R., Gaillard V., Borrell-Damián L. Research Assessment in the Transition to Open Science. (2019). P. 23. URL: https://eua.eu/resources/publications/888:research-assessment-in-the-transition-to-open-science.html.
} 
вимірювання його результативності, про що стверджується у Маніфесті «Альметрика» ${ }^{171}$. У ньому передбачено, що для оцінювання дослідницької роботи академічного персоналу доцільно враховувати альтернативні метрики в соціальних мережах, а саме: «рівень уваги до результатів наукової праці (скачування, перегляди публікацій), їх поширення (обговорення в блогах і на форумах, згадка в новинах, репости в соціальних мережах) і їх вплив на суспільство (посилання на наукову публікацію в експертних висновках, урядових документах тощо)» ${ }^{172}$. Зазначена структура альтернативних метрик засвідчує, що категорія виміру в оцінюванні дослідника насамперед є орієнтиром, а не прямим показником якості його результатів діяльності. Все ж наявність таких даних заслуговує на увагу для використання їх експертами 3 метою забезпечення якісного експертного оцінювання.

Загалом перевагами альтметрики $\epsilon^{173}$ : необмеженість: вимірювання впливу не лише в науковій галузі, але і в інших сферах; різноманітність: вимірювання різних типів об'єктів дослідження (наприклад, дані, програмні засоби та додатки); багатогранність: один і той самий об'єкт може вимірюватися за допомогою кількох сигналів (наприклад, коментарі, твіти, лайки, перегляди, завантаження); швидкість: альтметричні сигнали з'являються швидше, ніж звичайні показники. 3 іншого боку, доцільно враховувати і застереження, що виникають у процесі використання альтметрик ${ }^{174}$ : відсутність надійності, вільного доступу до баз даних, ризики для загальної етики системи науки, зокрема поява суперництва, не заснованому на науковій якості тощо.

Незважаючи на те, що на початку дискусій у науковому та освітньому просторах щодо введення альтметрик через їх потенціал і соціальне охоплення широко підтримувалося, остаточне розроблення та їх використання не завершено, що зумовлено необхідністю сформованої системи валідності та надійності. Саме тому важливими є висновки про використання альтметрик в оцінюванні дослідників, що обґрунтовані експертною групою Європейської комісії з альтметрики ${ }^{175}$ :

- відкрита наукова система повинна ґрунтуватися на поєднанні експертного оцінювання, кількісних та якісних вимірів;

- вирішальне значення в оцінюванні мають прозорість і точність метрик на основі надійності даних; визнанні того, що кількісна оцінка підтримує, але не замінює якісну експертну оцінку; відкритості даних, які можна перевірити; різноманітності як підтримку всебічної дослідницької діяльності та кар'єрного зростання; рефлексивності, що зумовлює системні та потенційні наслідки метричних показників та їх відповідне оновлення;

- надання переваги існуючим показникам для відкритої науки, зокрема показники використання (підрахунок переглядів або завантажень), співпраця (через співавторство), вплив на суспільство (твіти, лайки, публікації та підписки) тощо;

- доказовість показників майбутнього, які підкріплені відкритою, прозорою та пов'язаною інфраструктурою даних. Для формування стандартизованих показників потрібно розробляти та просувати унікальні, однозначні, стійкі, перевірені, відкриті, глобальні ідентифікатори.

Особливо такі оцінювання вчених $є$ надзвичайно важливими для наукових досліджень соціогуманітарних наук і вимагають подальшого вдосконалення та розроблення необхідного інструментарію.

\section{Структурні компоненти оцінювання і розвитку дослідницької діяльності НПП}

У цілому до особливостей оцінювання ефективності розвитку персоналу віднесено ${ }^{176 .}$ «комплексність оцінки; значну залежність показників ефективності від цілей розвитку; необхідність урахування індивідуальних особливостей та суб'єктивних чинників; низьку інформативність та відносність грошових показників; зумовленість зовнішніми умовами та чинниками; складність здійснення до завершення

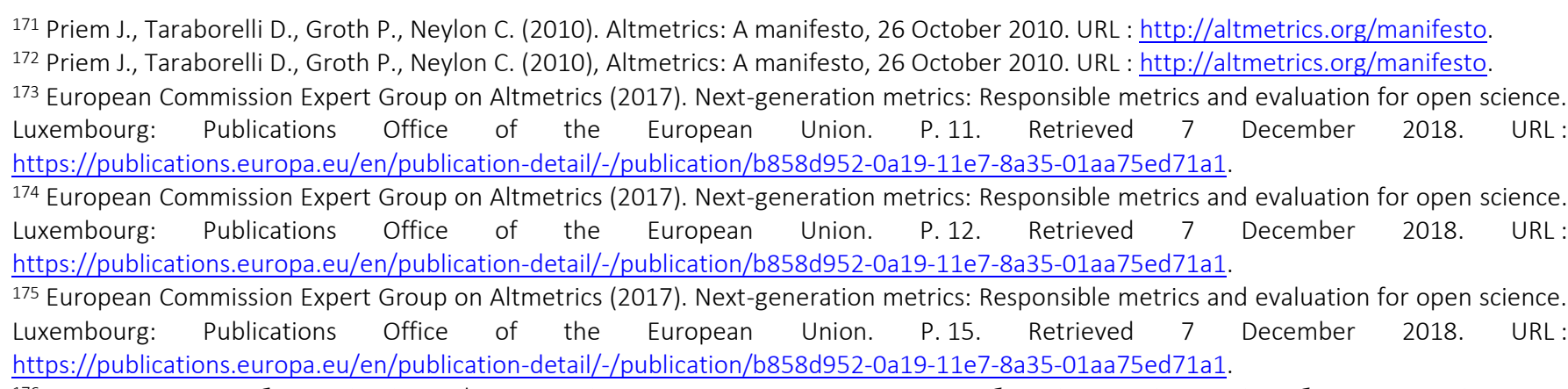
176 Ушкальов В.В. Особливості оцінки ефективності процесу розвитку персоналу. Глобальні та національні проблеми економіки. 2018. Вип. 23. С. 326-329. С. 329. URL : http://global-national.in.ua/archive/23-2018/64.pdf. 
етапу процесу розвитку або процесу розвитку взагалі». Ключовими чинниками, які зумовлюють достовірність оцінювання ефективності розвитку персоналу, $\epsilon^{177}$ : комплексність; контекстуальна зумовленість цілям організації; вплив зовнішнього середовища; особливості функціонування когнітивної сфери працівника; релевантність методів оцінки та їх практична спрямованість. За напрямами оцінювання персоналу здійснюється: у рамках визначених цілей ${ }^{178}$; комплексної оцінки на основі якостей особистості, трудової діяльності та досягнень ${ }^{179}$; відповідно до рівнів управління персоналом ${ }^{180}$. Для оцінювання персоналу поширеними $€$ такі групи методів ${ }^{181}$ : рейтинговий; метод есе; графічні шкали рейтингу; критичної ситуації; примусового вибору; «метод $360^{\circ} » ;$ «центрів оцінки і розвитку».

У вітчизняних ЗВО оцінювання наукової роботи відповідно до Закону України «Про вищу освіту» проводиться на етапі заміщення вакантних посад на конкурсних засадах, щорічного підтвердження займаної посади та атестації не рідше раз у п'ять років. У сучасних умовах відсутня єдина нормативно визначена методика оцінювання наукової діяльності НПП університетів, що зумовлено їх інституційною автономією. 3 огляду на це, ЗВО самостійно розробляють нормативні документи, які регламентують порядок, умови, вимоги, критерії та показники оцінювання зокрема і дослідницької діяльності НПП.

Особливо ретельно оцінювання відбувається на етапі добору викладацького персоналу, що здійснюється на конкурсних засадах. Ключовими вимогами під час добору на посаду, зокрема, $\epsilon^{182}$ : наявність наукового ступеня, результативність дослідницької діяльності, що підтверджується публікаційною активністю (кількість статей у журналах, що індексуються в базах Web of Science та Scopus; імпакт-фактор наукового журналу, у якому опублікована стаття; індекс Хірша), участь у наукових, грантових проєктах і госпдоговірних наукових досліджень; керівництво (консультування) здобувачами вищої освіти, які здобули ступені доктора PhD (доктора наук); іншомовна компетентність тощо.

Основними завданнями оцінювання НПП $\epsilon^{183 ;} 184 ; 185$ :

- «створення інформаційної бази для аналізу професійної діяльності працівників, кафедр, факультетів, інших підрозділів та ЗВО загалом;

- приведення діяльності ЗВО у відповідність до сучасних тенденцій розвитку вищої освіти і науки;

- формування системи стимулювання діяльності працівників ЗВО до вдосконалення якості освітньої та наукової діяльності, підвищення рівня їхньої кваліфікації, що сприяє підвищенню рейтингу ЗВО та його розвитку в цілому;

- забезпечення прозорості та об'єктивності оцінювання діяльності кожного НПП і структурного підрозділу;

- виявлення недоліків і проблемних питань у діяльності кафедр, факультетів та інших підрозділів 3BO;

- формування якісного науково-педагогічного складу 3ВО».

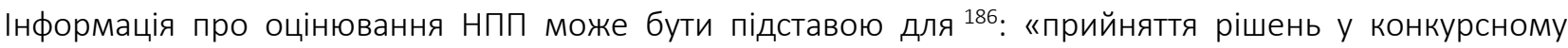

\footnotetext{
177 Ушкальов В.В. Особливості оцінки ефективності процесу розвитку персоналу. Глобальні та національні проблеми економіки. 2018. Вип. 23. С. 326-329. С. 329. URL : http://global-national.in.ua/archive/23-2018/64.pdf.

178 Сазонова Т.О. Осташова В.О. Система управління розвитком персоналу як важливий елемент менеджменту персоналу сучасного аграрного підприємства. Наукові розробки, передові технології, інновації : зб. наук. пр. та тез наук. доп. за мат-ми IV Міжн. наукпракт. конф. ; Прага-Брно-Київ. К. : НДІСР, 2017. С. 235-244.

179 Бучинська Т.В. Оцінка персоналу як важливий елемент ефективного управління. Економіка та управління підприємствами. 2017. № 1 (57). C. 59-64.

180 Соколовська В.В., Бабчинська О.І., Іванченко Г.В. Методи оцінки персоналу: роль та значення в управлінні. Агросвіт. 2019. № 20. C. 93-98. DOI : https://doi.org/10.32702/2306,6806.2019.10.93/

181 Данилевич Н.С., Поплавська О.М., Олішевська А.В. Оцінювання персоналу: практика використання сучасних методів, можливості поширення в Україні. Науковий вісник Ужгородського університету. Серія Економіка. 2018. Вип. 1 (51). С. 223-229. С. 225.

182 Грищенко І.М. Оцінювання ефективності діяльності науково-педагогічних працівників вищого навчального закладу. Trends and mechanisms providing economic security of European education under the conditions of globalization : collective scientific monograph / under the editing I.M. Gryshchenko, I.O. Tarasenko, A.O. Kasych, M.I. Skrypnyk. Agharta Science Publishing House, Szczecin, Poland, 2018. P. 250-264. C. 256.

183 Положення про оцінювання роботи та визначення рейтингів наукових, науково-педагогічних і педагогічних працівників / Львівський національний університет імені Івана Франка. (2017) С. 2. URL : https://www.Inu.edu.ua/wp-content/uploads/2017/05/reg rating.pdf.

184 Положення про оцінку ефективності працівників Українського католицького університету. (2020). URL : https://ucu.edu.ua/research/

185 Положення про рейтингове оцінювання професійної діяльності науково-педагогічних працівників / Тернопільський національний педагогічний університет імені Володимира Гнатюка. (2018). URL: http://tnpu.edu.ua/about/public inform/upload/2018/
} polozhennja pro rejtyngove otsinjuvannja.pdf. 
відборі на заміщення вакантних посад, щодо визначення терміну трудових відносин (продовження або припинення) із НПП, розподілу педагогічного навантаження, для матеріального і морального заохочення НПП».

Щорічне оцінювання здійснюється впродовж таких етапів ${ }^{187}$ : визначення цілей (на початку періоду); самооцінка НПП; оцінювання і зворотній зв'язок від керівника структурного підрозділу (кафедри, відділу) із визначенням професійного зростання вченого.

Визначення головних цілей НПП відбувається відповідно до пріоритетів, місії, стратегії ЗВО і завдань структурного підрозділу (кафедри, відділу) за відповідними напрямами діяльності з урахуванням конкретних індикаторів, які є реальними для виконання упродовж певного періоду ${ }^{188}$.

Щорічне оцінювання здійснюється в рамках самооцінки, на основі звіту кожного НПП відповідно до посад: асистент; викладач, старший викладач, доцент, професор. Програма самооцінювання НПП має ґрунтуватися на прозорій і відкритій системі моніторингу індикаторів оцінки.

За результатами аналізу зарубіжних і вітчизняних наукових та освітніх джерел варто виділити такі складники наукової діяльності НПП з відповідними показниками:

\section{Дослідницька діяльність:}

Наукові дослідження, зокрема керівництво / участь у наукових дослідженнях, що:

- виконуються за державні кошти;

- виконуються в рамках госпдоговірної тематики (стартапів);

- отримали грантову підтримку Національного фонду досліджень;

- отримали міжнародний науковий або освітній грант;

- у межах спільних (під керівництвом МОН України) міжнародних науково-дослідних проєктів;

- на здобуття Державних премій України;

- на здобуття стипендій і премій Президента України, Верховної Ради України, Кабінету Міністрів України, у т.ч. підготовка матеріалів тощо.

Публікаційна активність:

- публікація / підготовка монографій (розділів) у закордонному / вітчизняному видавництві;

- публікація / підготовка підручників;

- публікація навчальних посібників та методичних рекомендацій тощо;

- публікація статей у наукових виданнях, що індексуються Copernicus, Scopus, Web of Science тощо;

- публікація статей (тез) у фахових виданнях, збірниках наукових праць, наукових журналах.

Наукове визнання:

- кількість наукових праць, індексованих у Google Scholar, Scopus, Web of Science;

- індекс Гірша (h-index), зокрема за рік (Google Scholar);

- 10-index, зокрема за рік (Google Scholar)

\section{Наставничтво, керівництво:}

На здобуття наукових ступенів:

- керівництво здобувачами наукового ступеня доктора філософії (кандидата наук) (захист);

- консультування здобувачів наукового ступеня доктора наук (захист).

Сприяння у дослідницькій роботі студентів:

- підготовка студентів, призерів до Всеукраїнських студентських олімпіад (I, II етапи), конкурсів, турнірів;

- керівництво дипломними роботами студентів та магістрантів;

- керівництво студентськими науковими публікаціями;

- керівництво науковим студентським гуртком, науковим товариством тощо.

Науково-експертна діяльність:

Робота в спеціалізованих вчених радах:

- голова; вчений секретар; член ради.

робота в експертних комісіях спеціалізованих вчених рад:

\footnotetext{
186 Положення про оцінювання роботи та визначення рейтингів наукових, науково-педагогічних і педагогічних працівників / Львівський національний університет імені Івана Франка. (2017). С. $3 . \quad$ URL: https://www.Inu.edu.ua/wpcontent/uploads/2017/05/reg rating.pdf.

187 Положення про оцінку ефективності працівників Українського католицького університету.(2020). URL : https://ucu.edu.ua/research/ 188 Положення про оцінку ефективності працівників Українського католицького університету. (2020). URL : https://ucu.edu.ua/research/
} 
- експертиза дисертації на здобуття ступеня PhD (кандидатської), докторської;

- опонування дисертації на здобуття ступеня PhD (кандидатської), докторської.

Організаційно-видавнича діяльність

- головний редактор, заступник головного редактора (відповідальний секретар), член редколегії фахового видання;

- головний редактор, заступник головного редактора (відповідальний секретар), член редколегії нефахового видання.

Рецензування:

- наукових, виробничо-практичних, навчальних, довідкових видань.

Робота в комісіях, радах, групах :

- акредитаційних, експертних радах і комісіях МОН України;

- радах факультету, ЗВО томо;

- громадських радах томо.

Оприлюднення, впровадження:

- акти впровадження наукових досліджень;

- авторські свідоцтва,

- патенти на наукові роботи тощо.

Міжнародна наукова діяльність:

- спільні публікації із закордонними вченими;

- спільні видання із закордонними організаціями наукових праць: монографій, збірників статей тощо;

- закордонні відрядження для участі у наукових конференціях, семінарах.

Науково-організачійна діяльність:

- організація міжнародних та Всеукраїнських конференцій, семінарів, виставок тощо;

- організація регіональних, обласних та університетських конференцій, семінарів, виставок тощо;

- організація Всеукраїнських студентських олімпіад і конкурсів студентських наукових робіт;

- організація та участь у кафедральних та міжкафедральних семінарах.

Професійне зростання:

Підготовка дисертаційних робіт:

- особистий захист дисертації на здобуття доктора наук;

- особистий захист дисертацій для здобуття наукового ступеня доктора філософії;

- стажування у вітчизняних та закордонних 3ВО, організаціях тощо;

- отримання сертифіката, що підтверджує рівень володіння іноземною мовою.

Отримання вченого звання:

- професора; доцента, старшого дослідника;

- академіка / члена-кореспондента НАН України;

- академіка / члена-кореспондента національної галузевої академії наук України;

- академіка / члена-кореспондента інших академій наук.

Отримання почесного звання, державної, відомчої нагороди, гранту, премії за наукову діяльність:

- заслужений діяч або працівник України;

- інша державна нагорода;

- відзнака МОН (відомча) України;

- отримання гранту, стипендії, премії на рівні держави (міжнародному);

- отримання гранту, стипендії, премії на рівні області (міста);

- отримання звання ЗВО.

Науково-інформаційна діяльність, популяризація зво:

- у ЗМІ (теле-, радіопрограми);

- соцмережах, спеціалізованих онлайн-платформах, наукових блогах;

- науково-практичні зв'язки з партнерами, стейкхолдерами.

Для оцінювання діяльності НПП важливим є також урахування його самоідентифікації, тобто надання 
переваг тій чи іншій діяльності (дослідницькій, адміністративній тощо) ${ }^{189}$ :

За результатами щорічного оцінювання з боку адміністрації ЗВО можуть бути прийняті рішення про 190: відзначення НПП, зокрема, морального та матеріального заохочення кращих НПП; надання пропозицій про вдосконалення наукової діяльності з боку керівників структурних підрозділів; оголошення конкурсного відбору на заміщення вакантних посад НПП; оплату закордонних відряджень, стажування, участі в міжнародних конференціях тощо.

Третім важливим кроком в оцінюванні НПП є оцінка керівника структурного підрозділу (кафедри, відділу), оскільки він несе відповідальність за результати їх діяльності, надає пропозиції щодо заохочення або відповідного впливу, сприяє у визначенні професійного розвитку. Така оцінка здійснюється з метою ${ }^{191 .}$

- «прийняття рішення про просування НПП, їх переміщення на інші посади або до інших структурних підрозділів;

- інформування НПП про те, як їх оцінює керівництво;

- визначення оцінки внеску кожного НПП до колективного результату, оцінки результатів роботи структурних підрозділів про досягнення цілей кафедри, факультету, 3ВО;

- прийняття рішень щодо організації оплати праці;

- діагностики рішень про розвиток наукової діяльності».

Оцінювання з боку керівника структурного підрозділу ґрунтується на основі діалогу, під час якого узгоджується оцінка керівника і враховується самооцінка НПП, з'ясовуються його результативність, потреба у коригуванні досягненні цілей НПП на наступний період, вибудовування професійного зростання НПп ${ }^{192}$. Для запобігання ризиків суб'єктивного оцінювання з боку керівника структурного підрозділу, може створюватися експертна комісія, яка готує експертний висновок на основі самооцінки НПП, оцінки керівника НПП з урахуванням підтверджуючих кількісних і якісних даних.

Раз у п'ять років проводиться атестація НПП з метою ${ }^{193}$ «оцінювання рівня професійної підготовки, результативності його роботи; визначення відповідності його кваліфікації займаній посаді; виявлення перспективи використання його здібностей, стимулювання підвищення його професійного рівня; визначення потреби у підвищенні кваліфікації, його професійній підготовці». Атестація НПП здійснюється атестаційною комісією на підставі звіту НПП про виконання відповідно до займаної посади вимог із «документальним підтвердженням, зокрема 3 використанням наукометричних баз даних» ${ }^{194}$ та характеристики керівника структурного підрозділу. Результати атестації діяльності НПП є «основною підставою для прийняття рішень про подовження перебування на посаді, заохочення, накладання дисциплінарних стягнень, дострокове припинення трудових відносин тощо ${ }^{195}$.

Проведений аналіз зарубіжних і вітчизняних освітніх і наукових джерел з проблеми оцінювання наукової діяльності НПП дає підставу для таких висновків:

- в умовах інституційної автономії та відповідно до стратегії, місії, візії, цінностей ЗВО самостійно розробляє та формує систему оцінювання наукової діяльності НПП (напрями, умови, вимоги, критерії, показники тощо), що зумовлює прийняття з боку адміністрації ЗВО відповідних рішень про відповідність НПП займаній посаді, оплату праці, заохочення, професійний розвиток, оголошення конкурсного відбору на заміщення вакантних посад НПП тощо;

- наведений узагальнений рівень вимог до оцінювання наукової діяльності НПП зумовлює

\footnotetext{
189 Грищенко І.М. Оцінювання ефективності діяльності науково-педагогічних працівників вищого навчального закладу. Trends and mechanisms providing economic security of European education under the conditions of globalization : collective scientific monograph / under the editing I.M. Gryshchenko, I.O. Tarasenko, A.O. Kasych, M.I. Skrypnyk. Agharta Science Publishing House, Szczecin, Poland, 2018. P. 250-264.

190 Положення про критерії, правила і процедури оцінювання навчально-методичної, наукової та організаційної діяльності науковопедагогічних працівників державного закладу «Південноукраїнський національний педагогічний університет імені К.Д. Ушинського». (2019). URL : https://pdpu.edu.ua/doc/universitet/yakist/rating.pdf.

191 Данилевич Н.С., Поплавська О.М., Олішевська А.В. Оцінювання персоналу: практика використання сучасних методів, можливості поширення в Україні. Науковий вісник Ужгородського університету. Серія Економіка. 2018. Вип. 1 (51). С. 223-229. С. 225.

192 Положення про оцінку ефективності працівників Українського католицького університету. URL : https://ucu.edu.ua/research/

193 Про затвердження Положення про атестацію наукових працівників : постанова Кабінету Міністрів України від 13.08.1999 № 1475 URL : https://zakon.rada.gov.ua/laws/show/1475-99-n\#Text.

194 Про затвердження Положення про атестацію наукових працівників : постанова Кабінету Міністрів України від 13.08 .1999 № 1475 URL : https://zakon.rada.gov.ua/laws/show/1475-99-n\#Text.

195 Положення про організацію освітнього процесу у Київському національному університеті імені Тараса Шевченка. (2018). С. 110. URL : http://www.univ.kiev.ua/pdfs/official/Organization-of-the-educational-process.pdf.
} 
створення здорового конкурентного середовища, що впливає на мотивацію НПП, активізує його наукову діяльність на продуктивність, а також підвищує конкурентоспроможність ЗВО в цілому;

- найвагомішим в оцінюванні є критерії ефективності і результативності наукової діяльності НПП, оскільки це відображається на рейтингу ЗВО, що позиціонує його у суспільстві;

- оцінювання наукової діяльності НПП має бути зорієнтовано на якість виконаної за звітний період роботи з урахуванням здобутих надбань вченого;

- під час оцінювання НПП, які є керівниками структурних підрозділів (кафедр, відділів, факультетів) важливо враховувати сумарне оцінювання наукової діяльності підрозділу, яким вони керують;

- для оцінювання наукової діяльності НПП істотне значення мають цілі, відповідно до яких і провадиться оцінювання. Це дає змогу виявити сильні і слабкі сторони у проведеній роботі НПП та вибудувати на такій основі перспективу його професійного розвитку. 


\section{Висновки}

1.У системі вищої освіти в Україні актуалізується проблема оцінювання та розвитку науковопедагогічних працівників університетів у контексті реалізації наукової діяльності. Попри інституційну автономію і наявність у ЗВО розроблених відповідних нормативних документів, ця проблема $є$ злободенною та потребує вдосконалення, з огляду на необхідність підвищення ефективності діяльності НПП та забезпечення умов для їх професійного зростання, що зумовлено, з одного боку, вимогами відкритої науки і відкритого доступу до результатів досліджень вчених, з іншого - світовою пандемією COVID-19, що спричинила стрімке посилення цифровізації освітнього і наукового просторів.

2. Оцінювання і вдосконалення наукової діяльності НПП регламентується відповідними законодавчими та нормативно-правовими документами, в яких наскрізною ідеєю є вимога про об'єктивне оцінювання дослідницької діяльності вчених на основі вдосконалених відповідних інструментів, що сприятиме успішному професійному просуванню та визнанню наукової діяльності у суспільстві.

3. Характерною тенденцію в зарубіжному освітньому і науковому просторах під час оцінювання вчених університетів $€$ домінування наукометричних показників статей у журналах, що індексуються Scopus i Web of Science. Це спонукає дослідників до публікації сумнівних висновків, неправдивих позитивних результатів та шахрайства (фальсифікату) і $€$ відвертим наміром нечесності; унеможливлює відтворення здобутих результатів експериментальних досліджень та їх повторюваність, що $є$ одним із базових принципів європейської політики «Відкритої науки» і відкритого доступу; руйнує довіру громадськості і суспільства до наукових досягнень вчених, що особливо $€$ істотним в умовах світової пандемії внаслідок COVID-19; призводить до професійного вигорання дослідників, стресових ситуацій, що негативно впливає на якість і досконалість наукових досліджень в цілому.

4. Концептуальними засадами оцінювання і розвитку дослідницької діяльності науково-педагогічних працівників $€$ інтеграція двох збалансованих теорій: концепції бібліометрії і наукометрії та концепції досконалості у вищій освіті і дослідженнях. Оцінювання в рамках першої концепції здійснюється за результатами бібліометричних і наукометричних даних про результати досліджень ученого. Ключовим у концепції досконалості $€$ експертна оцінка, що враховує якість проведеного дослідження відповідно до встановлених стандартів, дає змогу визначити сильні і слабкі сторони та відповідно до цього -професійний розвиток.

Ураховуючи це, під оцінюванням і розвитком наукової діяльності НПП розуміємо встановлення відповідності наукової діяльності вченого університету вимогам стандарту до посади на основі експертного висновку, що формується за результатами комплексної експертної оцінки з урахуванням метричних показників, і дає змогу виявити переваги і недоліки та вибудувати дослідницьку перспективу і професійне зростання вченого.

5. Основоположні принципи політики ЄС та інших країн (Європейської хартії дослідників і Кодексу працевлаштування наукових працівників, Кодексу практики досліджень, Сан-Франциської декларації про оцінку наукових досліджень і Лейденського маніфесту, Гонконгських принципів, Маніфесту «Альметрика» тощо) засвідчують необхідність розроблення нових критеріїв та методів для об'єктивного і прозорого оцінювання, урахування різноманітних повноважень викладачів, які не тільки проводять наукові дослідження, але й беруть участь у науковому нагляді, наставництві, здійснюють управлінські або адміністративні функції у дослідницькій сфері, а також зобов'язують університети стимулювати, винагороджувати та оцінювати вчених за їх наукову діяльність, що сприяє доброчесності досліджень. На нашу думку, ключовими принципами оцінювання та розвитку науково-педагогічних працівників у частині їх наукової діяльності є: академічна доброчесність, досконалість, академічна свобода, відповідальність, безперервність, відкритість, лідерство, моніторинг.

6. В умовах інституційної автономії ЗВО відповідно до стратегії, місії, візії, цінностей самостійно розробляє та формує систему оцінювання наукової діяльності НПП:

- під час конкурсного відбору на посаду;

- щорічного оцінювання впродовж трьох етапів (визначення цілей (на початку періоду); самооцінки НПП; оцінювання і зворотного зв'язку від керівника структурного підрозділу (кафедри, відділу) із визначенням самоідентифікації НПП і його професійного зростання);

- атестації НПП не рідше раз у п'ять років.

7. За результатами аналізу зарубіжних і вітчизняних наукових та освітніх джерел до основних видів оцінювання наукової діяльності науково-педагогічних працівників 3ВО віднесено: дослідницьку діяльність 
(наукові дослідження, публікаційну активність, наукове визнання); наставництво, керівництво (на здобуття наукових ступенів, сприяння у науково-дослідній роботі студентів); науково-експертну діяльність (роботу в спеціалізованих вчених радах, експертних комісіях спеціалізованих вчених рад, організаційно-видавничу діяльність, рецензування, роботу в комісіях, радах, групах); оприлюднення, впровадження; міжнародну наукову діяльність; науково-організаційну діяльність; професійне зростання (підготовка дисертаційних робіт, отримання вченого і почесного звання, державної, відомчої нагороди, гранту, премії за наукову діяльність); науково-інформаційну діяльність; популяризацію 3ВО. 


\section{Список використаних джерел}

1. Бібліометрія: Лейденський маніфест для наукометрії. Філософська думка. 2017. № 6. С. 93-98.

2. Білощицький А.О., Кучанський О.Ю., Андрашко Ю.В., Білощицька С.В., Лященко Т.О. Управління розвитком складних систем. 2017. № 29. С. 151-159.

3. БороваТ.А. Створення системи професійного розвитку науково-педагогічних працівників вищого навчального закладу на засадах адаптивного управління. Педагогіка і психологія та медико-біологічні проблеми фізичного виховання i cnopmy. 2012. № 3. C. 16-20. URL: https://www.sportpedagogy.org.ua/html/journal/201203/12btaamp.pdf.

4. Бучинська Т.В. Оцінка персоналу як важливий елемент ефективного управління. Економіка та управління підприємствами. 2017. Вип. № 1 (57). С. 59-64.

5. Великий тлумачний словник сучасної української мови (з дод. і допов.) / уклад. і голов. ред. В.Т. Бусел. К. : Ірпінь : ВТФ «Перун», 2005. 1728 с.

6. Горошко А., Нарчинська Т., Озимок І., Тарнай В. Глосарій термінів з моніторингу та оцінювання / 2-е вид. К. : Укр.асоціація оцінювання, 2016. 53 c. URL : http://www.ukreval.org/images/publikacii/glossary.pdf.

7. Грищенко І.М. Оцінювання ефективності діяльності науково-педагогічних працівників вищого навчального закладу. Trends and mechanisms providing economic security of European education under the conditions of globalization : collective scientific monograph / under the editing I.M. Gryshchenko, I.O. Tarasenko, A.O. Kasych, M.I. Skrypnyk. Agharta Science Publishing House, Szczecin, Poland, 2018. P. 250-264.

8. Данилевич Н.С., Поплавська О.М., Олішевська А.В. Оцінювання персоналу: практика використання сучасних методів, можливості поширення в Україні. Науковий вісник Ужгородського університету. Серія Економіка. 2018. Вип. 1 (51). С. 223-229.

9. Дівінська Н. Теоретичні основи і модель розвитку іншомовної компетентності науково-педагогічного працівника. Теоретичні основи і технологія професійного розвитку науково-педагогічних працівників університетів в умовах інтеграції вищої освіти і науки : монографія / авт. кол. К. : Інститут вищої освіти НАПН України, 2019. 236 с. C. 147-162. URL: https://ihed.org.ua/wp-content/uploads/2020/04/Tehnologiva prof rozvitku pracivn VNZ Monogr IVO2019-236p avtors-kolektiv.pdf.

10. Дорожня карта інтеграції України до Європейського дослідницького простору (ERA-UA), схвалена рішенням колегії Міністерства освіти і науки України, протокол від 22.03.2018 № 3/1-7. URL: https://mon.gov.ua/storage/app/media/kolegiya-ministerstva/2018/05/1-dorozhnya-karta-integratsii-ukraini-do-evro.pdf.

11. Драч І.І. Управління дослідницькою діяльністю в системі університетського врядування: теоретичні основи. Аналіз провідного вітчизняного та зарубіжного досвіду розвитку щодо механізмів реалізації ефективного врядування в університетах : препринт (аналітичні матеріали) (частина I) / авт. кол.: І. Драч, С. Калашнікова, О. Паламарчук, В. Рябченко, Л. Червона ; за заг. ред. С. Калашнікової. К. : Інститут вищої освіти НАПН України, 2018. С. 67. URL : $\quad$ https://ihed.org.ua/wpcontent/uploads/2019/09/Analiz_dosvidu_vriaduvania_v_univer_ch1_analit_IVO-2018$147 p$ avtors-kolektiv.pdf.

12. Драч І.І. Філософський аналіз практики дослідницького врядування в університетах Великої Британії. Університети і лідерство. 2018. № 2 (6). C. 45-57. DOI : https://doi.org/10.31874/2520-6702-2018-6-2-45-57.

13. Жабенко О.В. Професійний розвиток науково-педагогічних працівників університетів в умовах інтеграції вищої освіти і науки: моделі і технологія. Теоретичні основи і технологія професійного розвитку науково-педагогічних працівників університетів в умовах інтеграції вищої освіти і науки : монографія / авт. кол. К. : Інститут вищої освіти HАПН України, 2019. 236 c. $\quad$ C. 40-83. URL: https://ihed.org.ua/wpcontent/uploads/2020/04/Tehnologiya prof rozvitku pracivn VNZ Monogr IVO-2019-236p avtors-kolektiv.pdf.

14. Заключний звіт незалежного європейського аудиту національної системи досліджень та інновацій України. (2017). URL : https://op.europa.eu/mt/publication-detail/-/publication/adb1f077-dedc-11e6-ad7c-01aa75ed71a1/languageuk/format-PDF/source-120740890.

15. Захарін C. Про наукову роботу закладів вищої освіти. URL: http://osvita.ua/blogs/ 77860/?fbclid=IwAR2U6An3lalpj7BkOSoz-X8vCA8wfjdySnwZr3B9nROyOPfwPczVhyiO9Sk.

16. Калашнікова С. Професійний розвиток керівників вищих навчальних закладів: аналіз провідного зарубіжного досвіду. Проблеми освіти. 2013. № 74. 4. 1. С. 11-22.

17. Кравченко Г.Ю. Адаптивне управління розвитком інститутів післядипломної педагогічної освіти в Україні : монографія. К. : Педагогічна думка, 2015. 300 с.

18. Луговий В., Оржель О., Таланова Ж. Забезпечення якості вищої освіти в університетах України. Оцінювання якості вищої освіти в умовах євроінтеграції: методичні рекомендації. / авт. кол. Київ : Ін-т вищої освіти НАПН України, 2019. 125 c. DOI : https://doi.org/10.31874/978-617-7486-33-5-2019.

19. Луговий В.І. Реалізація науково-педагогічної функції викладача в контексті стратегії розвитку вищої освіти в Україні. Вісник Національної академії педагогічних наук України. 2020. № 2 (2). DOI : https://doi.org/10.37472/2707-305X2020-2-2-11-3.

20. Луговий В.І., Слюсаренко О.М., Таланова Ж.В. Реалізація дослідницько-інноваційного потенціалу 
університетів як невід'ємного складника їх діяльності. Наука та наукознавство. 2019. № 3 (105). С. $26-45$.

21. Луговий В.І., Слюсаренко О.М., Таланова Ж.В. Моніторинг, мотивація, мобілізація задля конкурентоспроможності університетів України: механізми реалізації. Вісник Національної академії педагогічних наук України. 2020. № 2(2). DOI : https://doi.org/10.37472/2707-305X-2020-2-2-13-1.

22. Методичні рекомендації для закладів вищої освіти з підтримки принципів академічної доброчесності (2018). URL : https://mon.gov.ua/storage/app/media/vishcha-osvita/2018/10/25/recomendatsii.pdf.

23. МOH України пропонує для громадського обговорення проєкт профстандарту на посади «асистент», «викладач», «старший викладач», «доцент», «професор». URL: https://mon.gov.ua/ua/news/mon-proponuye-dlyagromadskogo-obgovorennya-proyekt-profstandartu-na-posadi-asistent-vikladach-starshij-vikladach-docent-profesor.

24. Національний класифікатор України. ДК 003:2010. Про затвердження, внесення зміни та скасування нормативних документів : наказ Держспоживстандарту України від 28.07.2010 № 327. URL: https://zakon.rada.gov.ua/ rada/show/v0327609-10\#Text.

25. Петренко Л.М. Стратегічні орієнтири професійного розвитку науково-педагогічних працівників в умовах відкритої освіти. 2020. DOI : https://doi.org/10.32405/2218-7650-2020-13(42)-170-184.

26. Положення про критерії, правила і процедури оцінювання навчально-методичної, наукової та організаційної діяльності науково-педагогічних працівників державного закладу «Південноукраїнський національний педагогічний університет імені К.Д. Ушинського». (2019). URL : https://pdpu.edu.ua/doc/universitet/yakist/rating.pdf.

27. Положення про організацію освітнього процесу у Київському національному університеті імені Тараса Шевченка. (2018). URL : http://www.univ.kiev.ua/pdfs/official/Organization-of-the-educational-process.pdf.

28. Положення про оцінку ефективності працівників Українського католицького університету. URL: https://ucu.edu.ua/research/

29. Положення про оцінювання роботи та визначення рейтингів наукових, науково-педагогічних і педагогічних працівників / Львівський національний університет імені Івана Франка. 2017. URL: https://www.Inu.edu.ua/wpcontent/uploads/2017/05/reg rating.pdf.

30. Положення про рейтингове оцінювання професійної діяльності науково-педагогічних працівників / Тернопільський національний педагогічний університет імені Володимира Гнатюка. (2018). URL: http://tnpu.edu.ua/about/public inform/upload/2018/polozhennja pro rejtyngove otsinjuvannja.pdf.

31. Про вищу освіту : Закон України від 01.07.2014 № 1556-VII. URL : https://zakon.rada.gov.ua/laws/show/155618\#Text.

32. Про державну атестацію закладів вищої освіти в частині провадження ними наукової (науково-технічної) діяльності : наказ МОН України від 12.03.2019 № 338. URL : https://zakon.rada.gov.ua/laws/show/z0688-19\#Text.

33. Про затвердження Ліцензійних умов провадження освітньої діяльності : постанова Кабінету Міністрів України від 30.12.2015 № 1187. URL : https://zakon.rada.gov.ua/laws/show/1187-2015-n\#Text.

34. Про затвердження Положення про атестацію наукових працівників : постанова Кабінету Міністрів України від 13.08.1999 № 1475. URL : https://zakon.rada.gov.ua/laws/show/1475-99-n\#Text.

35. Про наукову і науково-технічну діяльність : Закон України від 26.11.2015 № 848-VIII. URL: https://zakon.rada.gov.ua/laws/show/848-19\#Text.

36. Про освіту : Закон України від 05.09.2017 № 2145-VIII. URL : https://zakon.rada.gov.ua/laws/show/2145-19\#Text.

37. Професійно-педагогічна компетентність викладача вищого навчального закладу : навчальний посібник / за ред. І.Л. Холковської. Вінниця : ТОВ «Нілан лТД», 2017. 144 с.

38. Регейло І.Ю. Розвиток ціннісної компетентності науково-педагогічних працівників університетів в умовах інтеграції вищої освіти і науки. Теоретичні основи і технологія професійного розвитку науково-педагогічних працівників університетів в умовах інтеграції вищої освіти і науки : монографія / авт. кол. К. : Інститут вищої освіти НАПН України, 2019. 236 с. $\quad$ C. 163-225. URL: content/uploads/2020/04/Tehnologiya prof rozvitku pracivn VNZ Monogr IVO-2019-236p avtors-kolektiv.pdf.

39. Результати загальнонаціонального опитування «Перспективи та потреби розвитку університетів України у процесі реформування вищої освіти у контексті європейської інтеграції» / авт. кол. К. : Інститут вищої освіти НАПН України, 2019. 77 с. Університети і лідерство. 2019. № 2 (8). С. 144-220. DOI : https://doi.org/10.31874/2520-6702-20198-2-144-220.

40. Сазонова Т.О., Осташова В.О. Система управління розвитком персоналу як важливий елемент менеджменту персоналу сучасного аграрного підприємства. Наукові розробки, передові технології, інновації : зб. наук. пр. та тез наук. доп. за мат-ми IV Міжн. наук-практ. конф. ; Прага-Брно-Київ. К. : НДІСР, 2017. С. 235-244.

41. Сисоєва С.О., Козак Л.В. Дослідницька компетентність викладача вищої школи: програма розвитку. Неперервна професійна освіта: теорія і практика. 2016. Вип. 1-2. С. 39-44. URL : http://nbuv.gov.ua/UJRN/NPO 2016 1-2 9.

42. Скиба Ю.А. Порівняльний аналіз управління науково-дослідницькою діяльністю у вищих навчальних закладах України (остання чверть XX ст. і початок XXI ст.). Концепція та методологія реалізації науково-дослідницької діяльності суб'єктів навчально-виховного процесу університетів : монографія / авт. кол. К. : Інститут вищої освіти НАПН України, 2016. 178 с. С. 45-52. URL: https://ihed.org.ua/wp-content/uploads/2018/09/mon.-Konc-ta-metod-naukdosI diyaln-subyektiv-Univs IVO-NAPN-2016-178s.pdf. 
43. Скиба Ю.А. Професійний профіль і кваліфікаційні рівні науково-педагогічних працівників університетів в умовах інтеграції вищої освіти і наук. Теоретичні основи і технологія професійного розвитку науково-педагогічних працівників університетів в умовах інтеграції вищої освіти і науки : монографія / авт. кол. К. : Інститут вищої освіти НАПН України, 2019. 236 с. $\quad$ C. 4-39. URL: content/uploads/2020/04/Tehnologiva prof rozvitku pracivn VNZ Monogr IVO-2019-236p avtors-kolektiv.pdf.

44. Соколовська В.В., Бабчинська О.І., Іванченко Г.В. Методи оцінки персоналу: роль та значення в управлінні. Агросвіm. 2019. № 20. С. 93-98. DOI : https://doi.org/10.32702/2306,6806.2019.10.93/

45. Старостіна O.В. Досвід підвищення кваліфікації викладачів вищої школи у Великій Британії. 2020. DOI : https://doi.org/10.26661/2522-4360-2020-1-55.

46. Таланова Ж. Міжнародний, національний та інституційний виміри запровадження механізмів оцінювання якості вищої освіти. Аналіз провідного вітчизняного та зарубіжного досвіду щодо оцінювання якості вищої освіти в умовах євроінтеграції: аналітичні матеріали (частина І) (препринт) / О. Воробйова, М. Дебич, І. Линьова, В. Луговий, О. Оржель, О. Слюсаренко, Ж. Таланова, К. Трима ; за ред. В. Лугового, Ж. Таланової. Київ : Ін-т вищої освіти НАПН $\begin{array}{lllll}\text { України, } 2018 . & \text { C. 24-52. } & \text { URL : }\end{array}$ content/uploads/2019/08/Analiz ocinki VO v umovah internac ch1 analit IVO-2018-172p avtors-kolektiv.pdf.

47. Ушкальов В.В. Особливості оцінки ефективності процесу розвитку персоналу. Глобальні та національні проблеми економіки. 2018. Вип. № 23. С. 326-329. URL : http://global-national.in.ua/archive/23-2018/64.pdf.

48. Центральноєвропейський університет. URL : https://ctl.ceu.edu/call-applicationsnominations.

49. Чорнойван Г.П. Теоретичні основи і технології кар'єрного розвитку науково-педагогічних працівників у контексті інтеграції викладацької і дослідницької діяльності. Теоретичні основи і технологія професійного розвитку науково-педагогічних прачівників університетів в умовах інтеграції вищої освіти і науки : монографія / авт. кол. К. : Інститут вищої освіти НАПН України, 2019. 236 с. URL: https://ihed.org.ua/wp-content/uploads/2020/04/ Tehnologiva prof rozvitku pracivn VNZ Monogr IVO-2019-236p avtors-kolektiv.pdf.

50. Чорнойван Г.П. Механізми розвитку кар'єри дослідника в системі вищої освіти України у світлі інтеграції до Європейського дослідницького простору. Концепція та методологія реалізації науково-дослідницької діяльності суб'єктів навчально-виховного процесу університетів : монографія / авт. кол. К. : Інститут вищої освіти НАПН України, 2016. 178 c. C. 122-138. URL: https://ihed.org.ua/wp-content/uploads/2018/09/mon.-Konc-ta-metod-nauk-dosl diyalnsubyektiv-Univs IVO-NAPN-2016-178s.pdf.

51. Ярошенко О.Г. Теоретичні основи і технологія розвитку дослідницької компетентності науково-педагогічних працівників в умовах інтеграції вищої освіти і науки. Теоретичні основи і технологія професійного розвитку науковопедагогічних працівників університетів в умовах інтеграції вищої освіти і науки : монографія / авт. кол. К. : Інститут вищої освіти НАПН України, 2019. 236 с. С. 110-146. URL: https://ihed.org.ua/wp-content/uploads/2020/04/ Tehnologiya prof rozvitku pracivn VNZ Monogr IVO-2019-236p avtors-kolektiv.pdf.

52. Ярошенко О.Г. Теоретичні основи розвитку дослідницької компетентності науково-педагогічних працівників в умовах інтеграції вищої освіти і науки. Університети і лідерство. 2018. № 1 (5). С. 26-36.

53. Ярошенко О.Г., Скиба Ю.А. Концепція реалізації науково-дослідницької діяльності суб'єктів освітнього процесу університетів. Концепція та методологія реалізації науково-дослідницької діяльності суб'єктів навчальновиховного процесу університетів : монографія / авт. кол. К. : Інститут вищої освіти НАПН України, 2016.178 с. С. 27-29. URL : https://ihed.org.ua/wp-content/uploads/2018/09/mon.-Konc-ta-metod-nauk-dosl diyaln-subyektiv-Univs IVO-NAPN2016-178s.pdf.

54. Abu Saada I.J. Applying Leadership Criterion of EFQM Excellence. Model In Higher Education Institutions. URL: https://library.iugaza.edu.ps/thesis/109608.pdf.

55. Academic Ranking of World Universities. URL : http://www.shanghairanking.com/aboutarwu.html.

56. Altbach P. The Costs and Benefits of World-Class Universities. International Higher Education. 2003. № 33. URL : https://doi.org/10.6017/ihe.2003.33.7381.

57. Angermuller J. Academic careers and the valuation of academics. A discursive perspective on status categories and academic salaries in France as compared to the U.S., Germany and Great Britain. High Education. 2017. № 73. P. 963-980. DOI : https://doi.org/10.1007/s10734-017-0117-1.

58. Baldrige Excellence Framework (Education). URL: https://www.nist.gov/baldrige/publications/baldrigeexcellence-framework/education.

59. Bell B., Cowie B. Teacher development for formative assessment. Waikato Journal of Education. 2001. № 7. URL : https://researchcommons.waikato.ac.nz/bitstream/handle/10289/6265/Bell\%20teacher.pdf\%3Bsequence=1.

60. Bell B., Gilbert J. Teacher Development: A Model from Science Education. London - New York : Routledge Taylor\& Francis Group, 2004. 190 p.

61. Bhalla N., Welch M. Strategies to improve equity in faculty hiring. 2019. DOI : https://doi.org/10.1091/mbc.E19$\underline{08-0476 .}$

62. Blaškováa M., Blaškoa R., Kucharpíková A. Competences and Competence Model of University Teachers. Procedia - Social and Behavioral Sciences. 2014. № 159. P. 457-467.

63. Brogt E. Engaging with different professional recognition and development opportunities for academic 
developers. International Journal for Academic Development. 2020. DOI : https://doi.org/10.1080/1360144X.2020.1840380.

64. Brusoni M., Damian R., Sauri J.G.I, Jackson S., Kömürcügil H., Malmedy M., Matveeva O., Motova G., Pisarz S., Pol P., Rostlund A., Soboleva E., Tavares O., Zobel L. The Concept of Excellence in Higher Education. (2014). DOI: http://dx.doi.org/10.13140/РГ.2.1.2146.7683.

65. Calvo-Mora A., Leal A, Roldan J.L. Quality Assurance in Education: An International Perspective. 2006. Vol. 14. № 2. P. 99-122. URL : https://eric.ed.gov/?id=EJ801665.

66. Code of Practice for Research. Promoting good practice and preventing misconduct. September 2009. URL : https://ukrio.org/wp-content/uploads/UKRIO-Code-of-Practice-for-Research.pdf.

67. Crawford S. Derek John De Solla Price (1922-1983): The man and the contribution. Bulletin of the Medical Library Association. 1984. № 72 (2). P. 238-239. PMID 6375781.

68. Crosier D., Kocanova D., Birch P., Davykovskaia O., Parveva T. Eurydice Brief. Modernisation of Higher Education in Europe: Academic Staff. 2017. URL: https://eacea.ec.europa.eu/national-policies/eurydice/content/modernisation-highereducation-europe-academic-staff-\%E2\%80\%93-2017 en.

69. Darroch P.I., Colledge L.H. Using research metrics responsibly and effectively as a researcher. Infozine. 2016. Special Issue 1. P. 23-24. DOI : https://doi.org/10.3929/ethz-a-010744984.

70. De Fraja G., Facchini G., Gathergood J. Academic salaries and public evaluation of university research: Evidence from the UK Research Excellence Framework. Economic Policy. 2019. Vol. $34 . \quad$ Issue 99. P. $523-583$. URL: https://doi.org/10.1093/epolic/eiz009.

71. EURASHE's 10 Commitments for the EHEA in 2020 - Vision \& Strategies. Brussels : EURASHE, 2012. P. 4. URL : https://www.eurashe.eu/library/mission-phe/EURASHE 10 Commitments for EHEA in 2020 March2010.pdf.

72. European Commission Expert Group on Altmetrics (2017). Next-generation metrics: Responsible metrics and evaluation for open science. Luxembourg: Publications Office of the European Union. Retrieved 7 December 2018. URL: https://publications.europa.eu/en/publication-detail/-/publication/b858d952-0a19-11e7-8a35-01aa75ed71a1.

73. European research area (ERA). URL : https://ec.europa.eu/info/research-and-innovation/strategy/era en.

74. European University Association. URL : https://eua.eu/

75. Fanelli D. Do Pressures to Publish Increase Scientists' Bias? An Empirical Support from US States Data. 2010. PLOS ONE 5 (4): e10271. DOI : https://doi.org/10.1371/journal.pone.0010271.

76. Final Draft 6 of the Rome Ministerial Communiqué. URL: http://www.ehea.info/Upload/BFUG DE UK 739 Draft 6 Rome Communique.pdf.

77. Frascati Manual 2015: Guidelines for Collecting and Reporting Data on Research and Experimental Development. The Measurement of Scientific, Technological and Innovation Activities. Glossary of Terms (2015). P. 379. URL: https://www.oecd-ilibrary.org/docserver/9789264239012-en.pdf?expires=1548749491\&id=id\&accname=guest\&checksum= E65709A4CF0F7B345FE93B662A7229E3.

78. Garfield E.The Agony and the Ecstasy-The History and Meaning of the Journal Impact Factor. International Congress on Peer Review and Biomedical Publication. Chicago. 2005. URL: http://www2.psych.utoronto.ca/users/ psy3001/files/JCR.pdf.

79. Grimes D.R., Bauch C.T., Ioannidis J.P.A. Modelling science trustworthiness under publish or perish pressure. 2018. R.Soc. Open Sci. 5: 171511. DOI : http://dx.doi.org/10.1098/rsos.171511.

80. Hämäläinen K., Pehu S., Wahlén S. Institutional Evaluations in Europe. (2001) URL: https://enqa.eu/indirme/papers-andreports/workshop-and-seminar/institutional.pdf.

81. Hicks D., Wouters P., Waltman L., Rijcke S., Rafols I. Bibliometrics: The Leiden Manifesto for research metrics. April 2015. Nature 520 (520):429-431. URL: https://www.nature.com/news/bibliometrics-the-leiden-manifesto-for-researchmetrics-1.17351.

82. Kalpazidou S.E., Bührer S., Schraudner M., Reidl S., Müller J., Palmen R., Haase S., Graversen E.K., Holzinger F., Striebing C., Groó D., Klein S., Rigler D., Høg U.E. A Conceptual Evaluation Framework for Promoting Gender Equality in and Innovation. URL: https://www.ucviden.dk/en/publications/a-conceptual-evaluation-framework-for-promoting-genderequality-i.

83. Kobayashi S., Dolin J., Søborg A., Turner J. (2017). Building Academic Staff Teaching Competencies: How Pedagogic Continuous Professional Development for Academic Staff Can Be Organised and Developed in Research-Intensive Universities. DOI : https://doi.org/10.1007/978-3-319-56499-9 5.

84. Lee I. Publish or perish: The myth and reality of academic publishing. Language Teaching. 2014. № 47 (2), P. 250261. DOI : https://doi.org/10.1017/S0261444811000504.

85. Moher D., Bouter L., Kleinert S., Glasziou P., Sham M.H., Barbour V. et al. (2020) The Hong Kong Principles for assessing researchers: Fostering research integrity. PLoS Biol 18(7): e3000737. DOI: https://doi.org/10.1371/ journal.pbio.3000737.

86. Morais R., \& Borrell-Damián L. (2018). Open Access 2016-2017 EUA Survey Results. Brussels: EUA. Retrieved 6 December 2018. URL: https://eua.eu/resources/publications/324:open-access-n-european-universities-results-from-the2016-2017-eua-institutional-survey.html.

87. Nerantzi C., Chatzidamianos G. Reflecting on Academic Development: A Dialogue About A FLEXible Journey. 
International Journal of Management and Applied Research. 2018. Vol.5. No 2. P.55-68. DOI: https://doi.org/10.18646/2056.52.18-005.

88. Open Science in Ukraine. Програма Publish Or Perish. URL : https://openscience.in.ua/publish-or-perish.html.

89. Open Science, European Commission. URL: https://ec.europa.eu/info/sites/info/files/research and innovation/ knowledge publications tools and data/documents/ec rtd factsheet-open-science 2019.pdf.

90. Open Science. URL : https://ec.europa.eu/digital-single-market/en/open-science.

91. Priem J., Taraborelli D., Groth P., Neylon C. (2010). Altmetrics: A manifesto, 26 October 2010. URL: http://altmetrics.org/manifesto.

92. Research Excellence Framework 2014: The results. URL : https://www.ref.ac.uk/2014/pubs/201401/

93. Research Excellence Framework. URL : https://www.ucl.ac.uk/research/ref.

94. Research in International Management. Publish or Perish on Microsoft Windows. URL: https://harzing.com/resources/publish-or-perish/windows.

95. Researcher Development Framework. 2009. URL: https://www.vitae.ac.uk/vitae-publications/rdfrelated/researcher-development-framework-rdf-vitae.pdf/view.

96. Royal Academy of Overseas Sciences. Evaluating researchers and research teams. URL: http://www.guidelines.kaowarsom.be/home.

97. Saenen B., Borrell-Damián L. Reflections on University Research Assessment: key concepts, issues and actors. (2019). URL: https://eua.eu/resources/publications/825:reflections-on-university-research-assessment-key-concepts,-issuesand-actors.html.

98. Saenen B., Morais R., Gaillard V., Borrell-Damián L. Research Assessment in the Transition to Open Science. (2019). URL : https://eua.eu/resources/publications/888:research-assessment-in-the-transition-to-open-science.html.

99. Saenen B., Borrell-Damián L. Reflections on University Research Assessment: key concepts, issues and actors. (2019). URL : https://eua.eu/resources/publications/825:reflections-on-university-research-assessment-key-concepts,-issuesand-actors.html.

100. San Francisco Declaration on Research Assessment. URL : https://sfdora.org/read/

101. Schiffbänker H. Grant allocation and gender disparity: identifying the bias factors. URL: https://eua.eu/resources/expert-voices/154:grant-allocation-and-gender-disparity-identifying-the-bias-factors.html.

102. Steed C. Excellence in Higher Education. Evaluating the Implementation of the Efqm Excellence Model ${ }^{\circledR}$ in Higher Education in the UK. Beiträge zur Hochschulforschung. 2002. Heft 1, 24. Jahrgang. URL: https://www.bzh.bayern.de/uploads/media/1-2002-steed.pdf.

103. Stern N. Building on success and learning from experience: an independent review of the Research Excellence Framework. 2016.

https://assets.publishing.service.gov.uk/government/uploads/system/uploads/attachment data/ file/541338/ind-16-9-refstern-review.pdf.

104. Sušanj Z. Ana Jakopec A. Đorić A. Academics' effectiveness and professional development in Croatia: Challenges for human resource management in higher education institutions. 2020. URL : https://doi.org/10.1111/ejed.12422.

105. The European Charter for Researchers \& the Code of Conduct for their Recruitment. Європейська хартія дослідників та Кодекс працевлаштування наукових працівників. URL: http://h2020.com.ua/wpcontent/uploads/2015/11/Book.pdf.

106. The European Foundation for Quality Management Excellence Model. URL: https://www.efqm.org/index.php/efam-model/

107. The European University Association and Science Europe Join Efforts to Improve Scholarly Research Assessment Methodologies. URL : http://www.scienceeurope.org/media/xybdxw0e/joint-statement-eua-se-on-researchassessment-1.pdf.

108. The National Academies Press. Fostering Integrity in Research. URL: https://sites.nationalacademies.org/PGA/PGA 178432.

109. Togia A., Koseoglou E., Zapounidou S. Alternative Metrics for the Evaluation of Scholarly Activities: An Analysis of Articles Authored by Greek Researchers. URL : https://www.academia.edu/33686475/Alternative Metrics for the Evaluation of Scholarly Activities An Analysis of Articles Authored by Greek Researchers.

110. Veenstra C.P. Work in progress Innovation using the baldrige process. 37th Annual Frontiers In Education Conference - Global Engineering: Knowledge Without Borders, Opportunities Without Passports, Milwaukee, WI, 2007, pp. T2G-24-T2G-25. DOI : http://dx.doi.org/10.1109/FIE.2007.4418052. 


\title{
Теоретичні основи використання інноваційних технології розвитку науково- педагогічних працівників закладів вищої освіти: психологічний і колегіальний підходи
}

\author{
Вікторія Муромець, \\ кандидат педагогічних наук, \\ старший науковий співробітник, \\ Відділ інтеграції вищої освіти і науки, \\ Iнститут вищої освіти НАПН України \\ https://orcid.org/0000-0001-7071-121X
}

Анотація. У статті представлено форми професійного розвитку науково-педагогічних працівників за видами реалізації: традиційні і стандартизовані; за масштабністю реалізації - централізовані, інституційні та саморозвиток; за кількістю учасників - індивідуальні й колегіальні. Визначено найпоширеніші індивідуальні (спостереження за діяльністю провідних викладачів, саморозвиток, рефлексія, виконання нових ролей, портфоліо) та колегіальні форми професійного розвитку (інноваційні освітні мережі, спеціалізовані телепередачі, педагогічні команди, Інтернет-мережі, каскадність, ситуативне навчання, конференції, семінари, супервізія, теленаставництво, спільні наукові дослідження тощо). Охарактеризовано низку інноваційних форм професійного розвитку (каскадна, ситуативна, теленаставництво, супервізія тощо). Визначено психологічні переваги і недоліки використання інноваційних технологій для професійного розвитку науково-педагогічних працівників.

Ключові слова: інноваційні технології, професійний розвиток, науково-педагогічні працівники, університетські кейси. 


\section{Актуальність проблеми використання інноваційних технології розвитку науково-педагогічних працівників закладів вищої освіти: психологічний і колегіальний підходи.}

Фундаментальною основою розвитку світового людства, науково-технічного та економічного прогресу є освіта, від організації та змісту якої залежить розквіт країн у цивілізаційному напрямі. Розвиток системи вищої освіти вимагає від педагогічної науки й практики вивчення і впровадження інноваційних технологій та нових методів розвитку науково-педагогічних працівників (далі - НПП). Інновації в педагогіці пов'язані із загальними процесами у суспільстві, глобалізаційними та інтеграційними процесами. У Паризькому комюніке (2018) ${ }^{1}$ наголошується «на потребі щодо обміну практиками інноваційного навчання і викладання в Європейському просторі вищої освіти, а також підтримці і стимулюванню різних інноваційних технологій, методів навчання і викладання, зокрема і для професійного розвитку викладачів закладів вищої освіти. Оскільки висока якість викладання має важливе значення для здобуття високоякісної освіти і здійснює високий внесок у розвиток суспільства».

Реальний стан розвитку національної системи освіти характеризується наразі не динамічними змінами через досягнення науково-технічного прогресу та поширення сучасних інформаційних технологій, як це відбувається в розвинених країнах. У цьому сенсі терміново потрібно надати імпульс цілісності всім прогресивним реформам освіти (які розрізнено здійснюються сьогодні в Україні) та розробити власний вектор оновлення всієї системи освіти в контексті модернізації економіки нашої держави.

Найціннішим стратегічно важливим ресурсом будь-якої країни $€$ інтелектуальний капітал, основою якого $€$ інтелектуальна еліта нації (науковці, дослідники, НПП та ін.). Формування банку відповідного людського капіталу цілком залежить від наявності здібностей і талантів громадян, їх пізнавальної активності та бажання до навчання протягом всього життя.

Розвинені країни світу особливої уваги та пріоритетності надають розвитку вищої освіти в одночасно двох надважливих напрямах: підвищенню якості підготовки здобувачів закладів освіти; формуванню і розвитку педагогічного та науково-педагогічного потенціалу. Розвиток педагогічного та науковопедагогічного складу працівників здійснюється шляхом створення всіх необхідних умов для постійного професійного розвитку, запровадження новітніх технологій, методів, форм освітнього процесу, удосконалення матеріально-технічної виробничої бази, а також покращання престижності їх професії тощо.

Вітчизняні науковці сьогодні відчувають гостру потребу розширювати власні компетентності, набувати провідного досвіду, який дійсно їх робить конкурентоспроможними в сучасному освітньому середовищі. Тому часто шукають можливостей зробити це на стажуванні в університетах за кордоном, де застосовують все більше інноваційних методів та технологій навчання, які в сучасних умовах $є$ найбільш ефективними.

Тому ми вивчали провідний зарубіжний досвід використання інноваційних технологій розвитку НПП університетів із метою застосування їх у вітчизняних закладах вищої та післядипломної освіти в сучасних умовах.

Мета дослідження: встановити види інноваційних технології розвитку НПП закладів вищої освіти та психологічні особливості їх використання.

Завдання дослідження: здійснити теоретичний аналіз сутності інноваційних технологій професійного розвитку НПП у контексті трансформації вищої освіти; визначити особливості впровадження інноваційних технологій професійного розвитку НПП.

Методи дослідження. Для вирішення поставлених завдань буде використано комплекс методів дослідження: теоретичний аналіз вихідних положень андрагогіки; узагальнення, порівняння, систематизація.

Основна ідея дослідження полягає у вивченні провідного досвіду щодо впровадження інноваційних технологій професійного розвитку НПП.

Впровадження провідних ідей із використання інноваційних технологій для професійного розвитку НПП буде ефективним за умови з'ясування й урахування психологічних особливостей використання інноваційних технологій у системі професійного розвитку НПП.

\footnotetext{
1 Paris Communiqué (Paris, May 25th 2018). URL: https://mon.gov.ua/storage/app/media/news/Hoвини/2018/06/06/12/paris-
} communiqueenua2018.pdf. 


\section{Визначення теоретичних основ використання інноваційних технології розвитку науково-педагогічних працівників закладів вищої освіти}

Інновації в освіті - це процес творення, запровадження та поширення в освітній практиці нових ідей, засобів, педагогічних та управлінських технологій, у результаті яких підвищуються показники (рівні) досягнень структурних компонентів освіти, відбувається перехід системи до якісно іншого стану. Слово «інновація» має багатомірне значення, оскільки складається з двох форм: власне ідеї та процесу її практичної реалізації.

Зрозумілим є посилений інтерес науковців до актуальних питань щодо розроблення інноваційних освітніх технологій, їх впливу на особистість, способів їх ефективного й оптимального використання в під час професійного розвитку НПП. Використання інноваційних технології сприяє підвищення ефективності процесу професійного розвитку НПП.

Проблема професійного розвитку персоналу досліджують зарубіжні науковці: політичний, соціальний, культурний та економічний аспекти неперервного професійного розвитку (Л. Дерлінг- Хаммонд, M. Taŭm); розвиток навчальних програм професійного розвитку (K. Претm, A. Eraut, N. MacKenzie \& A. Staley); зміст професійного розвитку педагога (C. Зепеде, M. Pic, A. Росc); моделі, методи і форми професійного розвитку (П. Гріммет, К.Дуінлен, Дж.Троя, П. Уонг, Tracy Х.P.Zou); впровадження інформаційнокомунікаційних технологій у неперервний професійний розвиток (M. Mecep, Дж. Фальк, J. Macdonald).

Різні аспекти проблеми використання інноваційних технологій представлено у працях вітчизняних і зарубіжних науковців, зокрема: загально-методологічні питання розроблення інноваційних технологій (К. Бондарева, Л. Буркова, Р. Гуревич, І. Дичківська, М. Єменко, І. Зязюн), педагогічні підходи до використання інноваційних технологій (В. Паламарчук, А. Підласий, І. Підласий, С. Сисоєва, Є. Чернихович та інші); упровадження інноваційних технологій в освітній процес (М. Пехота, Р. Буревич, С. Цвілік, В. Олійник, В. Семиченко та інші); використання хмарних технологій для професійного розвитку педагогів (B. Биков, М. Жалдак, Н. Морзе, О. Ігнатенко, С. Семеріков, М. Шиненко, Н. Сороко та інші).

Як зазначає О. Дубасенюк, «інноваційні технології - це цілеспрямований системний набір прийомів, засобів організації освітньої діяльності, що охоплює весь процес навчання від визначення мети до одержання результатів та ґрунтуються на внутрішніх умовах навчання» ${ }^{2}$.

Tracy X. P. Zou у праці «Community-based professional development for academics: a phenomenographic study» (2019) ${ }^{3}$ обґрунтовує можливості професійного розвитку науковців через соціальне залучення до громади або групи. Це феноменографічне дослідження розкриває можливість професійного розвитку через наставництво, моделювання та обмін добрими принципами та практикою.

A Hamza у праці «International Experience: An Opportunity for Professional Development in Higher Education» ${ }^{4}$ розкрито технологію трансформаційного навчання викладачів. Технологія трансформаційного навчання створює умови для апробації та оцінювання різних стилів навчання, нової поведінки в незнайомій аудиторії тощо. Запропонована технологія дає можливість НПП здійснити рефлексію власних стратегій викладання та їх удосконалення.

J. Macdonald у праці «Activity design in online professional development for university staff» ${ }^{5}$ досліджено професійний розвиток викладачів із застосуванням дистанційних технологій. Зазначено, що професійний розвиток викладачів здійснюється за допомогою текстів або веб-сайтів, доповнених семінарами-практиками. Не зважаючи на певні недоліки такого виду професійного розвитку, загалом така форма забезпечує гнучкість організації процесу професійного розвитку викладачів в Інтернет-спільнотах.

N. MacKenzie \& A. Staley у праці «Online Professional Development for Academic Staff: Putting the Curriculum First» ${ }^{6}$ подано різноманітні технології для підвищення цінності курсу післядипломної освіти в

\footnotetext{
2 Дубасенюк О.А. Інноваційні освітні технології та методики в системі професійно-педагогічної підготовки. Професійна педагогічна освіта: інновачійні технології та методики : монографія. Житомир : Вид-во ЖДУ ім. І. Франка, 2009. С. $14-47$.

${ }^{3}$ Tracy X.P. Zou Community-based professional development for academics: a phenomenographic study. Studies in Higher Education Journal. 2019. URL : https://www.tandfonline.com/doi/abs/10.1080/03075079.2018.1477129.

${ }^{4}$ Hamza A. International Experience: An Opportunity for Professional Development in Higher Education. Journal of Studies in International Education. 2010. Vol. 14. № 1. P. 50-69. URL : https//eric.ed.gov/?id=EJ873855.

${ }^{5}$ Macdonald J. Activity design in online professional development for university staff. URL https//www.eurodl.org/materials/contrib/2010/Janet Macdonald.pdf.

${ }^{6}$ Mackenzie N. \& Staley A. Online Professional Development for Academic Staff: Putting the Curriculum First. 2001. Vol. 38. URL: https://www.tandfonline.com/doi/abs/10.1080/147032901300002846.
} 
галузі освіти та професійного розвитку на основі гібридної моделі освітньої програми. На веб-сайті використовується технологія для впровадження проблемно орієнтованої навчальної програми, що дозволяє використовувати методи досвіду навчання, а також структурувати базу знань, що більше спирається на навчальну програму, засновану на цілях.

I. Секрет у праці «Формування іншомовної компетентності студентів вищих технічних навчальних закладів в умовах дистанційної освіти» ${ }^{7}$ обґрунтовано потенціал інформаційно-комунікаційних технологій до реалізації наступних дидактичних завдань:

- «підвищення якості освіти на основі взаємозв'язку загальнодидактичних принципів самостійності, активності і систематичності;

- розширення можливостей для безперервної освіти на основі реалізації принципів послідовності, наступності та доступності;

- забезпечення адекватного рівня підготовки педагогів-технологів для роботи з інформаційнокомунікаційними технологіями;

- вдосконалення змісту навчання з урахуванням взаємодії загальнодидактичних принципів, охоплюючи принцип науковості, наочності, доступності, зв'язку теорії з практикою;

- оптимізація процесу засвоєння знань студентами на основі взаємозумовленості таких загальнодидактичних принципів, як принцип розвивального навчання, принцип створення оптимальних умов для навчання, індивідуального та диференційованого підходу, раціонального модульного принципу навчання;

- постійне вдосконалення дидактичного забезпечення навчального процесу» ${ }^{8}$.

Вважаємо, що запропоновані дидактичні принципи можуть бути успішно використанні у професійній підготовці НПП.

Н. Кошечко у праці «/нновачійні освітні технології навчання та викладання у вищій школі» ${ }^{9}$ зазначає, що впровадження інноваційних технологій не піддається формалізації, потребує врахування людського чинника, зокрема переборення соціально-психологічних бар'єрів. Подоланню їх сприяють: 1) урахування установок, ціннісних орієнтацій, етичних норм поведінки; 2) застосування соціальнопсихологічних методів активного навчання учасників процесу 3 метою розвитку в них інноваційних здібностей, формування готовності до сприйняття та участі в інноваційних заходах.

Дослідження, яке представлено у статтях, визначило чотири загальні набори дискурсів дисциплінарний, дефіцитний, навички та перформативність. Усі ці показники представляють суперечливі позиції щодо діяльності з професійного розвитку академічного персоналу. Проте, розуміння суперечливості та дискусійності проблеми професійного розвитку викладачів створюють ідеальні контексти, в яких ці дискурси, що мають стримуючий вплив, можна критикувати і, можливо, замінювати дискурсами, які створюють сприятливі умови для діяльності з розвитку НПП закладів вищої освіти.

\section{Зарубіжний досвід професійного розвитку НПП закладів вищої освіти}

Досвід США .Нормативною основою професійного розвитку педагогів США є національні стандарти, що визначають його зміст, види та форми. Вони були розроблені Американською національною радою з розвитку персоналу США (National Staff Development Council).

Спираючись на дослідження A.M. Eraut ${ }^{10}$ (праця «Developing professional knowledge withina client centered orientation») ми дійшли висновку, що у США існують такі технології професійного розвитку:

- розвиток на основному місці роботи;

- стандартизований.

Стандартизований професійний розвиток передбачає його реалізацію на основі встановлених стандартів і враховує реальні потреби повсякденної педагогічної діяльності НПП.

Відповідно до визначених технологій професійний розвиток НПП здійснюється за індивідуальною

\footnotetext{
${ }^{7}$ Секрет І.В. Формування іншомовної компетентності студентів вищих технічних навчальних закладів в умовах дистанційної освіти : монографія. Дніпродзержинськ, 2011. 384 с.

${ }^{8}$ Секрет І.В. Формування іншомовної компетентності студентів вищих технічних навчальних закладів в умовах дистанційної освіти : монографія. Дніпродзержинськ, 2011. 384 с.

9 Кошечко Н. Інноваційні освітні технології навчання і викладання у вищій школі. Вісник Київського національного університету імені Tараса Шевченка: Педагогіка. 2015. Вип 1 (1). URL : http://nbuv.gov.ua/UJRN/vknutshp 2015110.

10 Eraut A.M. Developing professional knowledge withina client - centered orientation. In Guskey T. Huberman M. (Eds.). New paradigms and practices in Professional development. New York : Teachers College Press, 1995. C. 625.
} 
та/або колегіальною формами. Індивідуальними формами є:

- науково-практичні дослідження;

- складання письмових звітів про педагогічну діяльність;

- наставництво;

- ведення педагогічного щоденника, який є засобом професійного самоаналізу.

Колегіальними формами професійного розвитку НПП є:

- «теленаставництво»;

- супервізія;

- ситуативність;

- каскадність.

Теленаставництво - технологія навчання і розвитку молодих НПП, за якого більш досвідчені педагоги (наставники), використовуючи мережу Інтернет, діляться з молодими викладачами своїми знаннями та досвідом протягом певного періоду часу. Зазвичай, теленаставництво здійснюється висококваліфікованим педагогом, який виступає у ролі активного слухача/спостерігача та виконує такі функції: слідкує за роботою колеги-початківця, спрямовує його діяльність, ділиться інформацією, відповідає на питання, робить зауваження та надає поради і ресурси, які допомагають викладачу-початківцю професійно зростати, осмислювати свою діяльність та приймати певні рішення.

Супервізія інноваційна технологія професійного розвитку НПП. Функціями супервізії є: допомога викладачам освоїти нову посаду чи місце роботи; спостереження за діяльністю педагогів, які мають недоліки у професійній діяльності; створення психологічно комфортних умов для НПП під час діагностування і вирішення професійних конфліктів; оцінювання ефективності педагогічної діяльності колег тощо. Супервізія є самостійним видом педагогічного супроводу, яка має добрий потенціал для професійного розвиткунПП.

Серед інноваційних форм професійного розвитку викладачів особливе зацікавлення викликає каскадна форма. Суть якої полягає у проходженні кількома досвідченими педагогами широкомасштабної програми професійного розвитку, в процесі якої вони отримують професійну підготовку з конкретної навчальної дисципліни чи теми ${ }^{11}$. Після завершення програми вони повертаються у ЗВО для відтворення отриманої підготовки та передачі колегам отриманих знань та навичок.

Цікавою є так звана ситуативна форма професійного розвитку НПП, суть якої полягає у використанні актуальної практичної ситуації як основи для дискусій в малих групах. Аналіз таких ситуацій допомагає НПп побачити двозначність, конфліктність, складність у простій, на перший погляд, ситуації.

Досвід Англії. В умовах децентралізованої системи управління освітою в Англії, удосконаленням професійної компетентності НПП займаються на всіх рівнях: національному, регіональному та місцевому. Розрізняють «внутрішні» та «зовнішні» джерела підвищення кваліфікації педагогів.

До внутрішніх джерел належать заходи, які плануються і організовуються університетом та безпосередньо педагогом, а до зовнішніх - різноманітні курси в навчальних центрах при міських та регіональних управліннях освіти, університетах, вищих педагогічних навчальних закладах, а також проведення консультацій ${ }^{12}$.

Наразі в Англії педагогічна освіта представлена трьома взаємопов'язаними ланками: базова підготовка вчителя (initial teacher training), вступ до професійної діяльності вчителя-початківця (introduction аs a newlyqualified teacher) та підвищення кваліфікації або неперервний професійний розвиток (in-sеrvice training (INSET) or continued professional development) ${ }^{13}$.

У монографії Н. Мукан ${ }^{14} а$ акцентовано увагу на професійному розвитку викладачів університетів. Зокрема, сформульовано конкретні цілі у системі неперервної педагогічної освіти, серед яких - професійний та особистісний розвиток викладача.

Серед інноваційних технологій професійного розвитку НПП Англії можна виділити індивідуальні та групові. Індивідуальним технологіями професійного розвитку НПП є такі:

\footnotetext{
11 Пришляк О.Ю. Професійний розвиток педагогів у США і ФРН. Науковий вісник Ужгородського національного університету. Серія «Педагогіка, соціальна робота». 2013. Вип. 27. С. 159-162. URL : https://dspace.uzhnu.edu.ua/jspui/handle/lib/1866.

12 Scheerens J. Teachers' professional development. Europe in international comparison. An analysis of teachers' professional development based on the OECD's Teaching and Learning International Survey (TALIS). Luxembourg : Office for Official Publications of the European Union, 2010. 204 p.

${ }^{13}$ Gower R, Phillips D, Walters S. Teaching practice: A Handbook for teachers in training. Oxford : Macmillan Education, 2006.224 p.

${ }_{14}^{14}$ Мукан Н.В. Неперервна педагогічна освіта вчителів загальноосвітніх шкіл: професійне становлення та розвиток (на матеріалах Великої Британії, Канади, США) : монографія. Львів : Вид. Нац. ун-тету «Львівська політехніка», 2010. 284 с.
} 
- спостереження за діяльністю провідних викладачів;

- саморозвиток;

- рефлексія;

- виконання нових ролей;

- портфоліо.

Колективними технологіями професійного розвитку є:

- інноваційні освітні мережі;

- спеціалізовані телепередачі;

- педагогічні команди;

- інтернет-мережі;

- каскадність;

- ситуативне навчання.

Досвід Нідерландів. На основі аналізу практик професійного розвитку НПП Нідерландів встановлено, що університети пропонують різноманітні курси від початкового до вищого рівня (в University of Groningen 34 курси, а в Wageningen University and Research - понад 50 курсів ${ }^{15}$. Формуванню переліку таких навчальних курсів передує робота із визначення, чого ж саме потребують НПП для удосконалення практики викладання. Наприклад, щорічно в University of Groningen проводиться три сесії фокус групи, яка на основі пропозицій викладачів визначає тематику, стимулювання, методи і ресурси для професійного розвитку.

Технологіями професійного розвитку, які реалізуються в університетах Нідерландів є:

- тренінги на робочому місці;

- обмін знаннями і досвідом між колегами;

- курси із освітніх інновації;

- програми UTQ, STQ та освітнього лідерства.

В університетах Нідерландів із 2008 року професійний розвиток НПП здійснюється на основі Університетської викладацької кваліфікації (University Teaching Qualification (UTQ), як частини кадрової 109 політики із професіоналізації викладачів ${ }^{16}$.

Досвід Польщі. Ретельний аналіз сайтів державних університетів Республіки Польща щодо існуючих підходів до підвищення професійного рівня НПП засвідчив, що серед індивідуальних форм домінуючими $\epsilon$ такі інноваційні технології:

- менторинг;

- коучинг;

- стажування;

- участь у проектах.

Колективним формами професійного розвитку НПП є:

- курси;

- семінари;

- тренінги;

- виконання ґрантів.

Усталена практика свідчить, що в процесі самоуправління професійним розвитком НПП польських університетів на сучасному етапі суспільного розвитку важливу роль відіграє неперервне навчання: курси, навчання, семінари, тренінги, післядипломна освіта, самоосвіта. Ці та інші форми отримання нових компетентностей або вдосконалення вже наявних усе частіше пропонуються викладачам університетів Республіки Польща у формі e-learning як у рамках дистанційної, так і відкритої освіти, з використанням цифрових технологій ${ }^{17}$.

\footnotetext{
15 Теоретичні основи і технологія професійного розвитку науково-педагогічних працівників університетів в умовах інтеграції вищої освіти і науки : препринт (аналітичні матеріали) ; у 2-х частинах / авт. кол.: Н. Дівінська, Н. Дяченко, О. Жабенко, І. Регейло, Ю. Скиба, Г. Чорнойван, О.Ярошенко ; за ред. О.Ярошенко. К.: Інститут вищої освіти HАПН України, 2018. Ч. 2. С. 31. URL: https://ihed.org.ua/wp-content/uploads/2019/07/Teor_osnovi_prof rozvitku_pracivn_analitich_IVO-2018-105p_avtors-kolektiv.pdf.

16 Теоретичні основи і технологія професійного розвитку науково-педагогічних працівників університетів в умовах інтеграції вищої освіти і науки : препринт (аналітичні матеріали) ; у 2-х частинах / авт. кол.: Н. Дівінська, Н. Дяченко, О. Жабенко, І. Регейло, Ю. Скиба, Г. Чорнойван, О.Ярошенко ; за ред. О.Ярошенко. К. : Інститут вищої освіти HAПН України, 2018. Ч. 2. С. 31. . URL: https://ihed.org.ua/wp-content/uploads/2019/07/Teor osnovi prof rozvitku pracivn analitich IVO-2018-105p avtors-kolektiv.pdf.

${ }^{17}$ Андрощук І.М. Система управління професійним розвитком викладачів кафедр менеджменту університетів Республіки Польща :
} 


\section{Інноваційні технології розвитку НПП: зарубіжні університетські кейси}

Ми проаналізували зарубіжні університетські кейси, що дало можливість визначити технології професійного розвитку НПП (див. табл. 5).

Інноваційні технології розвитку НПП: зарубіжні університетські кейси

\begin{tabular}{|c|c|}
\hline Університет & Технологія розвитку \\
\hline $\begin{array}{l}\text { University of } \\
\text { Pittsburgh }\end{array}$ & $\begin{array}{l}\text { В університеті } € \text { централізований підрозділ професійного розвитку НПП (Центр } \\
\text { навчального розвитку та дистанційної освіти (CIDDE). Місією Центру } € \text { «сприяння досконалості } \\
\text { та інноваціям у навчанні та наукових заходах»для всіх категорій персоналу університету. } \\
\text { CIDDE надає прямі та допоміжні послуги для кафедр, наукових шкіл та університету в } \\
\text { цілому, зокрема регулярні програми професійного розвитку та програми підтримки для своїх } \\
\text { викладачів. Однією із технологій професійного розвитку НПП є гібридні курси (hybrid courses). }\end{array}$ \\
\hline $\begin{array}{l}\text { University of } \\
\text { Manchester }{ }^{18}\end{array}$ & $\begin{array}{l}\text { Професійний розвиток НПП здійснюється на основі інноваційних технологій. Інтернет- } \\
\text { навчання для викладачів (10-хвилинний CPD-ресурс). Доступний для усіх HПП і зорієнтований } \\
\text { на вдосконалення викладацьких навичок. } \\
\text { Серія семінарів для НПП з наставництва і тьюторства (Learning @ Lunch). Ці семінари } \\
\text { проводяться віч-на-віч із менш досвідченими колегами і доступні через університетський сайт } \\
\text { для широкого доступу. } \\
\text { Майстер-класи і воркшопи для НПп з найкращими експертами-наставниками, які } \\
\text { допоможуть розробити індивідуальний план професійного розвитку. }\end{array}$ \\
\hline University of Bath ${ }^{19}$ & $\begin{array}{l}\text { В університеті актуальними для навчання та розвитку НПП є інноваційний інтруметарій: } \\
\text { онлайн ресурси з наступних тем: } \\
\quad \text { - управління віддаленими командами; } \\
\text { - робота віддалено; } \\
\text { - баланс на роботі і вдома. } \\
\text { Модулі електронного навчання, зокрема «Персональний розвиток викладача: 101» (по } \\
20 \text { хвилин відео-контенту кожен) з наступними темами: } \\
\text { - } \quad \text { коучинг електронного навчання; } \\
\text { - } \quad \text { комунікаційне електронне навчання; } \\
\text { - } \quad \text { електронне навчання для прийняття рішень; } \\
\text { - } \quad \text { складне електронне навчання для розмов; } \\
\text { - } \quad \text { управління електронним навчанням команд; } \\
\text { - } \quad \text { електронне навчання презентацій; } \\
\text { - } \quad \text { електронне навчання управління проектами; } \\
\text { - } \quad \text { електронне навчання саморозвитку; } \\
\text { - } \quad \text { електронне навчання з управління часом. }\end{array}$ \\
\hline Stanford University 20 & $\begin{array}{l}\text { В університеті існує Програма розвитку персоналу, яка підтримує розвиток } \\
\text { співробітників, забезпечуючи часткове або повне відшкодування витрат на курси, семінари, } \\
\text { що дозволяють університетським працівникам покращити професійну результативність, } \\
\text { підготуватися до кар'єрного розвитку або відповідати вимогам програм професійного ступеня, } \\
\text { пов'язаних із поточною роботою або плановим кар'єрним розвимтком. }\end{array}$ \\
\hline
\end{tabular}

Нині опубліковано низку досліджень у яких подано психологічні особливості організації олайннавчання суб'єктів освітнього процесу (Vonderwell, 2004; Watkins et al., 2004; Pillay et al., 2007; Mercado, 2008; Dray et al., 2011; Farid, 2014; Wladis et al., 2016). Здійснений аналіз наукових праць засвідчив, що однією із особливостей навчання в онлайн-середовищі, зокрема в умовах інтенсивного навчання, $€$ врахування індивідуальних відмінностей (особливо самостійного або саморегульованого навчання) та самоефективності в Інтернеті. Крім того, рекомендується більш цілісний підхід до визначення готовності НПП до професійного розвитку, що охоплює ключові психологічні та технологічні особливості інтенсивного онлайн-навчання.

автореферат ... докт. пед. наук : 13.00 .06 - теорія та методика управління освітою. Київ, 2018.40 с.

18 Pedagogic and staff development programme / University of Manchester. URL : http://mystaffdevelopment.org/

19 The Development Toolkit - an online learning and development resource for staff / University of Bath. URL: https://www.bath.ac.uk/guides/the-development-toolkit-an-online-learning-and-development-resource-for-staff/

20 Staff Development Programs / Stanford University. URL : https://adminguide.stanford.edu/chapter-2/subchapter-1/policy-2-1-12. 
Нами у процесі дослідження встановлено психологічні переваги і недоліки використання інноваційних технологій професійного розвитку НПП.

До психологічних переваг використання інтенсивного онлайн-навчання НПП відносяться:

- відчуття НПП свободи, виклик внутрішніх резервів до самореалізації;

- розвиток бажання НПП до співробітництва, кооперації в будь якій діяльності;

- пошук можливостей реалізації в процесі навчання внутрішньої мотивації діяльності безпосередньо пов'язаної зі сферою потреб особистості;

- створення зручного освітнього середовища та гнучкої технічної підтримки в Інтернеті з метою утримання та залучення НПП до професійного розвитку;

- надання корекційної підтримки або виправлення будь-яких непередбачених технічних затримок чи затримок у навчанні.

Психологічними недоліками використання інтенсивного онлайн-навчання НПП є:

- обмеження у часі для вирішення будь-яких ключових проблем;

- обмеження у доступі до усього різноманіття служб підтримки онлайн-середовища;

- недостатність зручних в Інтернеті академічних ресурсів та широких можливостей для взаємодії слухачів та викладачів;

- низький рівень гнучкості технічної підтримки в Інтернеті з метою утримання та залучення НПП до професійного розвитку;

- недостатність орієнтаційних послуг для адекватної інтеграції слухачів в нове освітнє середовище в Інтернеті, що розвиває почуття відстороненості від спільноти;

- недостатній рівень технічної компетентності НПП, що може створити психологічний бар'єр та призвести до припинення або відмови від професійного розвитку НПП.

Потреба в науково обґрунтованих стратегіях профілактики психологічного дискомфорту є особливо важливою, враховуючи те, що НПП відчувають значний рівень психологічного розладу під час професійного розвитку із використанням інноваційних цифрових технологій. 


\section{Висновки}

1. Застосовувати інноваційні технології професійного розвитку НПП необхідно з урахуванням вікових категорій - рівнем їх компетентності у сфері сучасних інформаційних технологій, їх активності і мобільності у науково-дослідницькій та педагогічній діяльності. Тобто на кожну категорію має використовуватися відповідна технологія, яка буде найбільш ефективною.

2. Встановлено форми професійного розвиток НПП за видами реалізації: традиційні і стандартизовані; за масштабністю реалізації - централізованими, інституційними та саморозвиток; за кількістю учасників індивідуальні і колегіальні. Визначено найпоширеніші індивідуальні (спостереження за діяльністю провідних викладачів, саморозвиток, рефлексія, виконання нових ролей, портфоліо) та колегіальні форми професійного розвитку (інноваційні освітні мережі, спеціалізовані телепередачі, педагогічні команди, Інтернет-мережі, каскадність, ситуативне навчання, конференції, семінари, супервізія навчальні курси, теленаставництво спільні наукові дослідження тощо).

Охарактеризовано низку інноваційних форм професійного розвитку (каскадна, ситуативна, теленаставництво, супервізія тощо).

3. Визначено психологічні переваги (відчуття НПП свободи, виклик внутрішніх резервів до самореалізації; розвиток бажання НПП до співробітництва, кооперації в будь якій діяльності; пошук можливостей реалізації в процесі навчання внутрішньої мотивації діяльності безпосередньо пов'язаної зі сферою потреб особистості; створення зручного освітнього середовища та гнучкої технічної підтримки в Інтернеті з метою утримання та залучення НПП до професійного розвитку; надання корекційної підтримки або виправлення будь-яких непередбачених технічних затримок чи затримок у навчанні) і недоліки (обмеження у часі для вирішення будь-яких ключових проблем; обмеження у доступі до усього різноманіття служб підтримки онлайн-середовища; недостатність зручних в Інтернеті академічних ресурсів та широких можливостей для взаємодії слухачів та викладачів; низький рівень гнучкості технічної підтримки в Інтернеті 3 метою утримання та залучення НПП до професійного розвитку; недостатність орієнтаційних послуг для

адекватної інтеграції слухачів в нове освітнє середовище в Інтернеті, що розвиває почуття відстороненості від спільноти; недостатній рівень технічної компетентності НПП) використання інноваційних технологій для професійного розвитку НПП.

4. Ураховуючи виявлені причини психологічного дискомфорту використанням інноваційних цифрових технологій для професійного розвитку НПП особливо важливою $€$ потреба в науково обґрунтованих стратегіях його профілактики.

Способи вирішення психологічних проблем щодо упровадження інноваційних технологій професійного розвитку НПП закладів вищої освіти:

- застосування психологічних тестів, експертних оцінок, співбесід, розглядання конкретних ситуацій, для діагностики професійних компетентностей;

- обговорення його на нарадах, конференціях, семінарах кращих зарубіжних практик професійного розвитку НПП;

- обмін досвідом серед груп викладачів, які практикують інноваційні технології і здійснюють консультативно-аналітичну діяльність, відповідну проектної ідеї;

- визначення і періодичне уточнення (для розробки технологій розвитку) рівня інтелектуальної, етичної культури (самоорганізація рефлексії, мотивація до розвитку мислення, схильність до рефлексії, цілеспрямованість, готовність до самозміни, ціннісні орієнтири) і комунікабельності. 


\section{Список використаних джерел}

1. Андрощук І.М. Система управління професійним розвитком викладачів кафедр менеджменту університетів Республіки Польща : автореферат ... докт. пед. наук : 13.00.06 - теорія та методика управління освітою. Київ, 2018.40 с.

2. Дубасенюк О.А. Інноваційні освітні технології та методики в системі професійно-педагогічної підготовки. Професійна педагогічна освіта: інноваційні технології та методики: монографія. Житомир : Вид-во ЖДУ ім. І. Франка, 2009. C. 14-47.

3. Кошечко Н. Інноваційні освітні технології навчання і викладання у вищій школі. Вісник Київського національного університету імені Тараса Шевченка : Педагогіка. $2015 . \quad$ Bип 1 (1). URL: http://nbuv.gov.ua/UJRN/vknutshp 2015 1 10.

4. Мукан Н.В. Неперервна педагогічна освіта вчителів загальноосвітніх шкіл: професійне становлення та розвиток (на матеріалах Великої Британії, Канади, США) : монографія. Львів : Вид. Нац. ун-тету «Львівська політехніка», 2010. 284 c.

5. Пришляк О.Ю. Професійний розвиток педагогів у США і ФРН. Науковий вісник Ужгородського національного університету. Серія «Педагогіка, соціальна робота». 2013. Вип. $27 . \quad$ C. 159-162. URL: https://dspace.uzhnu.edu.ua/jspui/handle/lib/1866.

6. Секрет І.В. Формування іншомовної компетентності студентів вищих технічних навчальних закладів в умовах дистанційної освіти : монографія. Дніпродзержинськ, 2011. 384 с.

7. Теоретичні основи і технологія професійного розвитку науково-педагогічних працівників університетів в умовах інтеграції вищої освіти і науки : препринт (аналітичні матеріали) ; у 2-х частинах / авт. кол.: Н. Дівінська, Н. Дяченко, О. Жабенко, І. Регейло, Ю. Скиба, Г. Чорнойван, О. Ярошенко ; за ред. О. Ярошенко. К. : Інститут вищої освіти НАПН України, 2018. Ч. 2. С. 31. URL : https://ihed.org.ua/wp-content/uploads/2019/07/Teor osnovi_prof rozvitku_pracivn analitich IVO-2018-105p avtors-kolektiv.pdf.

8. Eraut A.M. Developing professional knowledge withina client - centered orientation. In Guskey T. Huberman M. (Eds.). New paradigms and practices in Professional development. New York : Teachers College Press, 1995. C. 625.

9. Gower R, Phillips D, Walters S. Teaching practice: A Handbook for teachers in training. Oxford: Macmillan Education, 2006. 224 p.

10. Hamza A. International Experience: An Opportunity for Professional Development in Higher Education. Journal of 113 Studies in International Education. 2010. Vol. 14. № 1. P. 50-69. URL : https//eric.ed.gov/?id=EJ873855.

11. MacdonaldJ. Activity design in online professional development for university staff. URL: https//www.eurodl.org/materials/contrib/2010/Janet Macdonald.pdf.

12. MacKenzie N. \& Staley A. Online Professional Development for Academic Staff: Putting the Curriculum First. 2001.

Vol. 38. URL : https://www.tandfonline.com/doi/abs/10.1080/147032901300002846.

13. Paris Communiqué (Paris, May 25th 2018). URL: https://mon.gov.ua/storage/app/media/news/Hoвини/ 2018/06/06/12/paris-communiqueenua2018.pdf.

14. Pedagogic and staff development programme / University of Manchester. URL : http://mystaffdevelopment.org/

15. Scheerens J. Teachers' professional development. Europe in international comparison. An analysis of teachers' professional development based on the OECD's Teaching and Learning International Survey (TALIS). Luxembourg : Office for Official Publications of the European Union, 2010. 204 p.

16. Staff Development Programs / Stanford University. URL : https://adminguide.stanford.edu/chapter-2/subchapter1/policy-2-1-12.

17. The Development Toolkit - an online learning and development resource for staff / University of Bath. URL: https://www.bath.ac.uk/guides/the-development-toolkit-an-online-learning-and-development-resource-for-staff/

18. Tracy X.P. Zou Community-based professional development for academics: a phenomenographic study. Studies in Higher Education Journal. 2019. URL : https://www.tandfonline.com/doi/abs/10.1080/03075079.2018.1477129. 